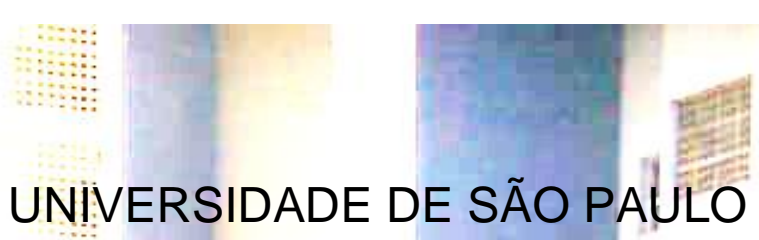

FACULDADE DE ARQUITEURA E URBANISMO

EDILSON HENRIQUE MINEIRO

\title{
LIMITES E DESAFIOS INSTITUCIONAIS DA PRODUÇÃO HABITACIONAL AUTOGESTIONÁRIA NO BRASIL
}

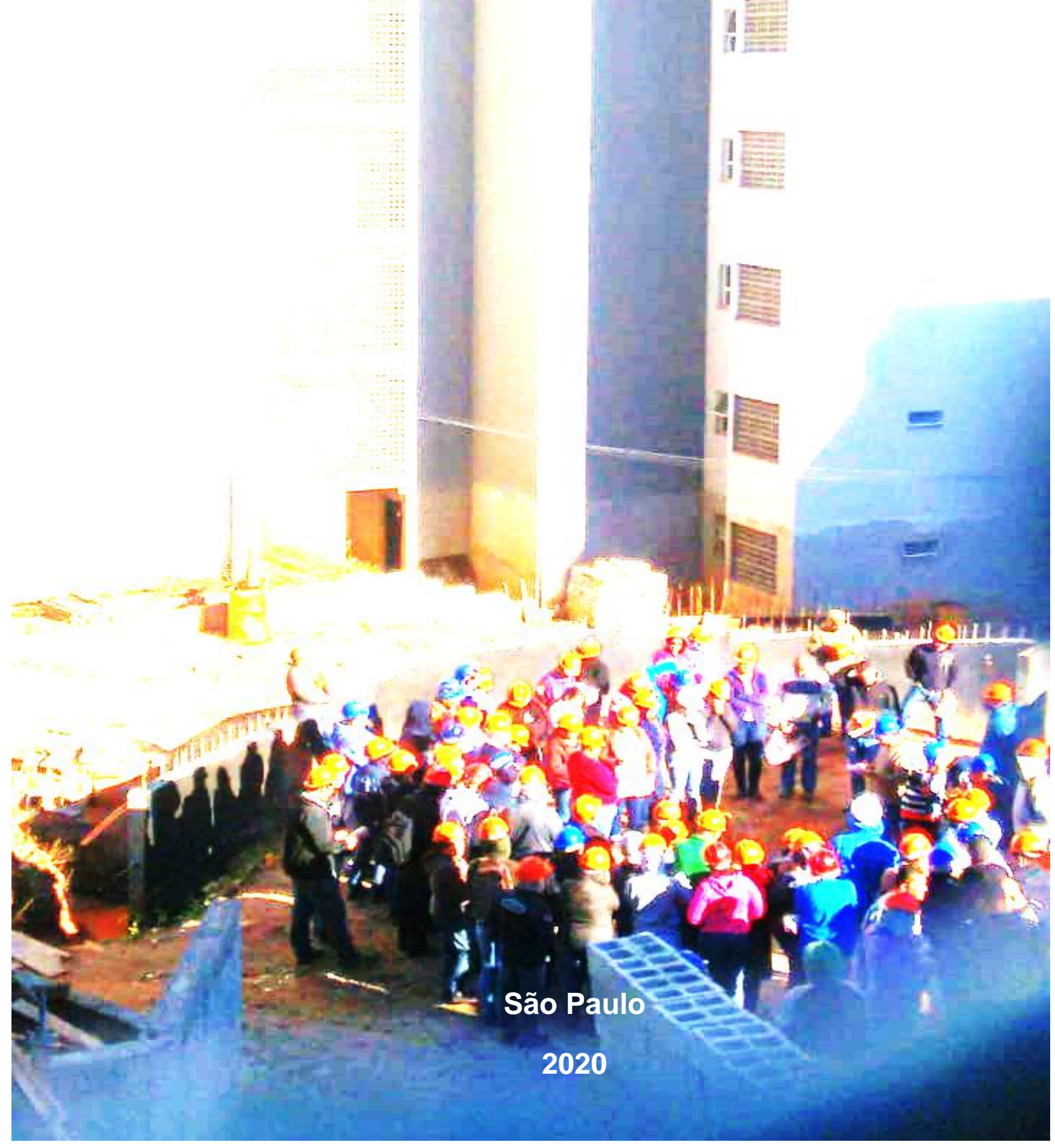


EDILSON HENRIQUE MINEIRO

\section{LIMITES E DESAFIOS INSTITUCIONAIS DA PRODUÇÃO HABITACIONAL AUTOGESTIONÁRIA NO BRASIL}

Dissertação apresentada ao Programa de Pós Graduação em Arquitetura e Urbanismo da Universidade de São Paulo como parte dos requisitos para a obtenção do título de mestre em ciências.

Área de concentração: Habitat

Nível: Mestrado

Orientador: Prof. Dr. Nabil Georges Bonduki

São Paulo

2020 
Autorizo a reprodução e divulgação total ou parcial deste trabalho, por qualquer meio convencional ou eletrônico, para fins de estudo e pesquisa, desde que citada a fonte.

Catalogação na Publicação

Serviço Técnico de Biblioteca

Faculdade de Arquitetura e Urbanismo da Universidade de São Paulo

Mineiro, Edilson Henrique

Limites e desafios institucionais da produção

habitacional autogestionária no Brasil / Edilson Henrique

Mineiro; orientador Nabil Georges Bonduki. - São Paulo,

2020 .

204 .

Dissertação (Mestrado) - Faculdade de Arquitetura e Urbanismo da Universidade de São Paulo. Área de concentração: Habitat.

1. Autogestão. 2. Movimentos Sociais. 3. Habitação Popular. 4. Minha Casa Minha Vida. I. Bonduki, Nabil Georges, orient. II. Título.

Elaborada eletronicamente através do formulário disponível em: 〈http://www.fau.usp.br/fichacatalografica/> 
Nome: MINEIRO, Edilson Henrique

Título: Limites e desafios institucionais da produção habitacional autogestionária no Brasil.

Dissertação apresentada à Faculdade de Arquitetura e Urbanismo da Universidade de São Paulo para a obtenção do título de Mestre em Arquitetura e Urbanismo, na Área de Concentração Hábitat.

Aprovado em:

\section{Banca Examinadora}

Prof. Dr. Instituição:

Julgamento: Assinatura:

Prof. Dr. Instituição:

Julgamento: Assinatura:

Prof. Dr. Instituição:

Julgamento: Assinatura: 


\section{DEDICATÓRIA}

Dedico este trabalho aos que lutam pela construção de uma sociedade livre e igualitária, especialmente nos tempos atuais que exigem ainda mais determinação para superar a barbárie. 


\section{AGRADECIMENTOS}

A Dona Maria Cecilia Mineiro e Benedito Egídio Mineiro, meus pais, que nunca descansaram.

À minha companheira de vida, Evaniza Rodrigues, que sonha junto e faz virar realidade.

À Ângela de Arruda Amaral, Henrique Pacheco, Miguel Reis Afonso, Pablo Gonzalez Olalla (in memorian), aos padres Xaverianos da Paróquia Sagrado Coração de Jesus, que obstinadamente se dedicam à construção de um mundo melhor.

Aos professores Francisco Comaru, loshiaqui Shimbo e Ricardo Moretti e aos companheiros e companheiras da Central de Movimentos Populares participantes do grupo de preparação de lideranças para ingresso na pós graduação, que levam a luta popular para dentro da universidade.

Aos professores Caio Santo Amore e Rosângela Paz, que, na banca de qualificação, apontaram questões fundamentais para reestruturação da pesquisa.

Aos amigos da caminhada, especialmente à coordenação dos empreendimentos Florestan Fernandes e José Maria Amaral, aos mutirantes, aos companheiros da Ambiente Assessoria Técnica e, especialmente à Arq. Renata Miron, pelo compartilhamento das angústias. 


\section{RESUMO}

MINEIRO. Edilson Henrique. Limites e desafios institucionais da produção habitacional autogestionária no Brasil. 2020. 204f. Dissertação de Mestrado. Faculdade de Arquitetura e Urbanismo - USP, 2020.

A proposta de produção autogestionária de moradia popular no Brasil está presente nos discursos e na prática das principais organizações de luta por moradia no Brasil durante as últimas quatro décadas.

Ao longo de sua trajetória ela foi executada em programas públicos dos diversos entes da administração. No entanto, essas experiências foram realizadas de modo pontual e descontinuo.

Isso se refletiu na constituição de uma legislação esparsa e majoritariamente veiculada por meio de regulamentos dotados de baixa capacidade de produzir segurança jurídica.

O objetivo dessa dissertação é produzir um diagnóstico do processo de institucionalização das propostas autogestionárias na produção habitacional no país e contribuir para o debate sobre a necessidade de construção de um marco jurídico abrangente e compatível com a característica transformadora da realidade social da qual a experiência é portadora.

Palavras-chaves: Habitação, Movimentos Sociais, Habitação Popular, Minha Casa Minha Vida. 


\begin{abstract}
MINEIRO. Edilson Henrique. Institutional limits and challenges of self-managed housing production in Brazil. 2020. 204f. Master Thesis. Faculdade de Arquitetura e Urbanismo - USP, 2020.
\end{abstract}

The model of popular housing production via self-management has been part of the discourses and practices of the main organizations who fight for housing for the past four decades.

In this trajectory, several government programs supported housing via selfmanagement. However, these experiences were conducted in a punctual and discontinuous manner.

The fragmented programs resulted in the enactment of sparse legislation, mainly conveyed through regulations with low capacity to produce legal certainty.

The objective of this thesis is to produce a diagnosis of the process that has institutionalized proposals for self-managed housing production in the country. The findings reveal the need to build a comprehensive legal framework, which sustains the social transformation aspects that the self-managed housing experiences bear.

Keywords: Self-managed housing production, Social Movements, Social Housing, Minha Casa Minha Vida 


\section{LISTA DE FIGURAS}

Figura 1 - Cartaz da Associação em Defesa da Moradia 44

Figura 2 - Mutirão São Francisco - Setor V 48

Figura 3 - Mutirão São Francisco - Setor V 48

Figura 4 - Representação do tripé da autogestão 56

Figura 5 - Prefeito discursa em manifestação da UMM/SP 69

Figura 6 - Área de Abrangência do MST Leste 1

Figura 7 - Atividade de acolhida novas famílias 135

Figura 8 - Localização do terreno dos empreendimentos 139

Figura $9-1^{\underline{a}}$ visita das famílias no terreno dos empreendimentos 140

Figura 10 - Mobilização na Caixa para a implementação da Compra Antecipada 144

Figura 11 - Parâmetros fornecidos pela Prefeitura para o terreno 145

Figura 12 - Atividade de celebração da compra da área e contratação do empreendimento 147

Figura 13 - Implantação proposta para aquisição da área 148

Figura 14 - Implantação proposta para aquisição da área 148

Figura 15 - Assembleia para a discussão de projeto 149

Figura 16 - Implantação Final aprovada 150

Figura 17 - Corte esquemático da implantação 150

Figura 18 - Atividade de discussão de projeto 151

Figura 19 - Representação da tramitação do processo de aprovação dos empreendimentos 153

Figura 20 - Representação da tramitação do processo em SEHAB 154

Figura 21 - Orçamento dos empreendimentos após aportes 156 
Figura 22 - Ocupação do Ministério das Cidades, 2013

Figura 23 - Ocupação do Ministério das Cidades, 2013

Figura 24 - Reunião de comissão de trabalho 161

Figura 25 - Reunião de comissão de trabalho 161

Figura 26 - Feira de habilidades dos mutirantes 162

Figura 27 - Transporte de material em mutirão - "formiguinha" 164

Figura 28 - Organização de dia de obra 165

Figura 29 - Resultado do trabalho em uma jornada de Mutirão 165

Figura 30 - Esquema de composição da Coordenação 167

Figura 31 - Assembleia durante a fase de obras 168

Figura 32 - Assembleia durante a fase de obras 168

Figura 33 - Exemplo de boletim de andamento de obra 170

Figura 34 - Assembleia para escolha dos acabamentos externos 171

Figura 35 - Votação para escolha dos acabamentos externos 171

Figura 36 - Ciclo de cotação e compra de materiais ou contratação de serviços 174

Figura 37 - Vista panorâmica dos empreendimentos em 2016

Figura 38 - Manifestação em defesa da liberação dos rendimentos do aporte

Figura 39 - Mutirão Solidário com grupos de origem 185

Figura 40 - Mutirão Solidário com grupos de origem 185

Figura 41 - Atividade de escolha das unidades habitacionais 187

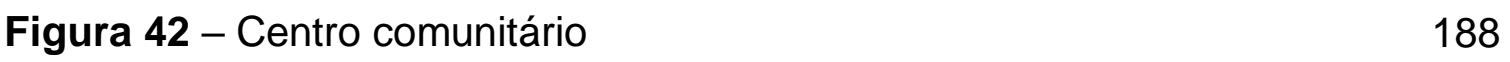




\section{LISTA DE TABELAS}

Tabela 1 - Período de vigência de cada fase do PMCMV 103

Tabela 2 - Faixas de renda atendidas em cada fase do PMCMV 103

Tabela 3 - Número de unidades habitacionais contratadas em cada fase 104 do programa por faixa de renda

Tabela 4 - Número de unidades habitacionais construídas em cada 105 modalidade da faixa 1 por fase do programa até 2018.

Tabela 5 - Número de unidades habitacionais contratadas nas 108 modalidades da faixa $1 \mathrm{em}$ cada fase

Tabela 6 - Dados dos empreendimentos Florestan Fernandes e José 132 Maria Amaral

Tabela 7 - Linha do tempo dos empreendimentos Florestan Fernandes e José Maria Amaral

Tabela 8 - Lista de atividades mensais obrigatórias para os mutirantes 159

Tabela 9 - Lista das comissões de trabalho 160

Tabela 10 - Desequilíbrio financeiro de itens de obra

\section{LISTA DE GRÁFICOS}

Gráfico 1 - Participação percentual de cada faixa de renda do programa 104 em cada fase

Gráfico 2 - Participação percentual de cada faixa de renda do programa 106 até 2018

Gráfico 3 - Participação percentual das modalidades da faixa 1

Gráfico 4 - Evolução da contratação do MCMV-E por ano 109 


\section{LISTA DE ABREVIATURAS E SIGLAS}

ADM - Associação em Defesa da Moradia

AT - Assessoria técnica

CAIXA - Caixa Econômica Federal

CAO - Comissão de Acompanhamento de Obra

CDHU - Companhia de Desenvolvimento Habitacional e Urbano

CF - Constituição da República Federativa do Brasil

CGFDS - Conselho Gestor do Fundo de Desenvolvimento Social

$\mathrm{CMH}$ - Conselho Municipal de Habitação do Município de São Paulo

CMP - Central dos Movimentos Populares

COHAB/SP - Companhia Metropolitana de Habitação de São Paulo.

CONAM - Confederação Nacional das Associações de Moradores

CONCIDADES - Conselho Nacional das Cidades

CRE - Comissão de Representantes do Empreendimento

FAR - Fundo de Arrendamento Residencial

FDS - Fundo de Desenvolvimento Social

FGTS - Fundo de Garantia por Tempo de Serviços

FMH - Fundo Municipal de Habitação do Município de São Paulo

FNHIS - Fundo Nacional de Habitação de Interesse Social

FNRU - Fórum Nacional de Reforma Urbana

FUNAPS - Fundo de Atendimento à População Moradora em Habitação Subnormal

FUNACOM - Programa FUNAPS Comunitário

FUNDURB - Fundo de Desenvolvimento Urbano do Município de São Paulo

GIHAB - Gerencia Regional de Habitação da Caixa Econômica Federal

IPPUR/UFRJ - Instituto de Pesquisa e Planejamento Urbano e Regional da

Universidade Federal do Rio de Janeiro

IPTU - Imposto Territorial e Urbano

LC - Lei Complementar

LO - Lei Ordinária

MCMV - Programa Minha Cada Minha Vida

MCMV Entidades - Programa Minha Cada Minha Vida Entidades

MCIDADES - Ministério das Cidades

MDR - Ministério do Desenvolvimento Regional 
MNLM - Movimento Nacional de Luta por Moradia

MST Leste 1 - Movimento dos Trabalhadores Sem Terra Leste 1

MTST - Movimento dos Trabalhadores Sem Teto

OGU - Orçamento Geral da União

PCS - Programa Crédito Solidário

PDE - Plano Diretor Estratégico

PLANAB - Plano Nacional de Habitação

PMCMV-E - Programa Minha Casa Minha Vida - Entidades

PNH - Política Nacional de Habitação

PNHR - Programa Nacional de Habitação Rural

PSM - Programa de Apoio à Produção Social da Moradia

SELVIP - Secretaría Latinoamericana de la Vivienda Popular

SNHIS - Sistema Nacional de Habitação de Interesse Social

TCM/SP - Tribunal de Contas do Município de São Paulo.

UMM/SP - União dos Movimentos de Moradia da Grande São Paulo e Interior.

UNMP - União Nacional por Moradia Popular. 


\section{SUMÁRIO}

$\begin{array}{ll}\text { 1. Introdução } & 17\end{array}$

2. Do FUNAPS ao PMCMV-E: aspectos elementares dos arranjos institucionais. 21

2.1. 1980 - A década da participação popular. 22

2.2. $\quad$ Agentes dos processos de mutirão autogerido 31

2.2.1. Os movimentos de moradia 32

2.2.2. As assessorias técnicas 36

2.2.3. $\quad$ As assessorias jurídicas e o papel dos advogados populares. 41

2.3. Os programas municipais 46

2.3.1. O Programa de Produção de Moradias em regime de $\begin{array}{ll}\text { mutirão autogerido } & 57\end{array}$

2.3.2. A autogestão no governo Haddad. 65

2.4. Autogestão e Governo do Estado. Os mutirões da $\begin{array}{ll}\text { CDHU. } & 71\end{array}$

3. Autogestão e produção social da moradia 77

3.1. A busca por um conceito de autogestão da moradia. 79

3.2. Características da participação autogestionária 80

3.3. Autogestão e Cooperativismo 83

3.4. Autogestão e ajuda mútua. 86

3.5. Autogestão e o marco legal da economia solidária. 87

4. $\quad 0$ marco legal da política e dos programas autogestionários nos governos Lula e Dilma. 90

4.1. $\quad$ O Plano Nacional de Habitação 92

4.2. As regras do Programa Crédito Solidário 94 
4.3. $\quad$ Autogestão no Minha Casa Minha Vida - Entidades 96

4.4. Contratações na Faixa 1 do PMCMV 106

4.5. Implicações políticas e jurídicas nos processos de produção autogestionária da moradia.

4.5.1. Autogestão e os princípios constitucionais.

4.5.2. $\quad$ Autogestão e a efetividade do direito à moradia.

4.5.3. O caráter não mercantil da produção autogestionária. 115

4.5.4. $\quad$ Autogestão como um dos regimes de construção 117

$\begin{array}{ll}\text { 4.5.5. } & \text { Seleção das famílias participantes }\end{array}$

$\begin{array}{lll}\text { 4.5.6. } & \text { Direito à Assessoria Técnica } & 121\end{array}$

4.5.7 Participação direta na tomada de decisão 124

$\begin{array}{lr}\text { 4.5.8. } & \text { Mutirão } \\ & 126\end{array}$

$\begin{array}{lll}\text { 4.5.9. } & 126\end{array}$

$\begin{array}{ll}\text { 4.5.10. } & \text { Orçamento e aportes }\end{array}$

$\begin{array}{lll}\text { 4.5.11. } & \text { Propriedade Coletiva } & 128\end{array}$

5. Os efeitos das limitações políticas e jurídicas nos empreendimentos habitacionais Florestan

Fernandes e José Maria Amaral.

5.1. Organização do Movimento Sem Terra Leste 1

$\begin{array}{lll}\text { 5.2. } & 137\end{array}$

$\begin{array}{lll}\text { 5.3. } & 137\end{array}$

$\begin{array}{ll}\text { 5.4. } & \text { Contrapartida financeira das famílias }\end{array}$

$\begin{array}{ll}\text { 5.5. } & \text { Compra do terreno }\end{array}$

$\begin{array}{ll}\text { 5.6. } & 147\end{array}$

$\begin{array}{ll}\text { 5.7. } & 151\end{array}$

$\begin{array}{ll}\text { 5.8. } & \text { Contratação da fase de obras }\end{array}$ 
$\begin{array}{ll}\text { 5.9. } & 159\end{array}$

5.10. Trabalho Social 162

5.11. Organização do trabalho mutirante 163

5.12. Organização da gestão - coordenação e assembleia 166

5.13. Gestão coletiva das Finanças 171

$\begin{array}{ll}\text { 5.14. Compras e contratações } & 173\end{array}$

$\begin{array}{ll}\text { 5.15. Vigília e caseiros } & 175\end{array}$

$\begin{array}{ll}\text { 5.16. Desenvolvimento de obra } & 178\end{array}$

5.17. Associação de Moradores e Condomínio 186

6. Considerações finais 189

Referências Bibliográficas 193 


\section{Introdução}

A pesquisa pretende analisar os limites políticos e jurídicos surgidos da implementação dos programas habitacionais destinados à execução de projetos habitacionais de interesse social desenvolvimentos por mutirão com autogestão no âmbito do governo federal no período entre 2003 e 2016.

Parte-se da premissa de que, apesar de inserida no campo das propostas de intervenção contra hegemônicas (LAGO, 2012), ainda permanece válida aquela conhecida como mutirão autogestionário, que, em síntese, possui caráter positivo e transformador seja no contexto político geral da busca pela constituição de cidades justas e democráticas ou no contexto da política habitacional isoladamente considerado.

A produção habitacional por mutirão e autogestão ocupa lugar destacado no mosaico de reivindicações que compõe o discurso das principais organizações representativas dos movimentos populares de moradia e seus elementos fundamentais evidenciam a perspectiva de valorização do protagonismo dos movimentos de moradia e suas reinvindicações baseadas nas ideias de solidariedade, ajuda mútua e autogestão, apoiados por equipes de assessoria técnica e cujas ações estão voltadas para a viabilização de direitos por meio da formulação e execução de políticas públicas.

O que a experiência demonstra é que não há um único modelo de autogestão, mas um conjunto de iniciativas que contribui para a construção de um movimento em defesa da produção social da moradia no país e na América Latina.

Contudo, a proposta da produção habitacional por mutirão com autogestão historicamente construída a partir das lutas populares sofreu fortes limitações de natureza política e jurídica ao longo do seu processo de institucionalização, especialmente na sua versão contemporânea, no âmbito do PMCMV-E (Programa Minha Casa Minha Vida - Entidades), executado no âmbito do governo federal.

O conteúdo da proposta autogestionária e o modo de operação dos movimentos populares sofreram alterações e a forma como os agentes públicos se relacionam com processos associativos também foi influenciada (NAIME, 2012). Numa aparente contradição, o processo de produção por mutirão e autogestão foi acolhido e limitado nas políticas públicas que foram analisadas neste estudo. (CAMARGO, 2016; TEIXEIRA, TATAGIBA e BLIKSTAD, 2015). 
Os desafios políticos e jurídicos extraídos dos processos autogestionários estão relacionados com os elementos constitutivos da experiência, são aqui relacionados como seu conteúdo mínimo ideal: (i) desafios de viabilização do direito a moradia digna; (ii) caráter não mercantil da produção; (iii) associativismo e cooperativismo habitacionais; (iv) participação direta e soberania assemblear; (v) ajuda mútua ou mutirão; (vi) natureza do trabalho das assessorias técnicas de arquitetura, jurídica e social; e das formas de propriedade.

A análise da regulação dos principais programas desenvolvidos nos últimos anos visa as mutações das regulamentações que em boa medida refletem nuances na perspectiva de atuação de cada agente em cada período histórico. A mera análise da legislação não comporta toda a complexidade que envolve o tema, mas é um ponto de partida para avaliar as posições, reações, avanços e recuos, vistos especialmente a partir da ótica daqueles que demandam o programa.

Além do esforço dos diversos atores dedicados à proposta em promover uma regulação que pudesse dar suporte legal e institucional a esse modo de produção, também o silêncio, percebido pela constatação da ausência de um quadro normativo, são eloquentes para demonstrar a importância da abordagem do tema.

A análise abarca de forma panorâmica os programas antecedentes com 0 foco essencialmente nos programas paulistas, cuja relevância, inclusive para as formulações atuais é consensual na literatura especializada.

Além disso, a análise também se dedicará ao período de 2003 a 2016 que equivale aos governos Lula e Dilma e que pode ter significado um ciclo determinado de tentativa de estruturação de uma política habitacional direcionada à absorção parcial dos principais debates ocorridos entre os estudiosos e ativistas do urbanismo brasileiro (SINGER, 2012; BALBIM, 2016).

Embora a avaliação geral sobre o período ainda careça maior amadurecimento, algumas tentativas, por consistentes, podem ser referenciadas. Para Singer (2012, p. 9) "O lulismo existe sob o signo da contradição. Conservação e mudança, reprodução e superação, decepção, esperança num mesmo movimento". O autor identifica nessa conformação um modo de operar que opta pela conciliação permanente de interesses contrapostos direcionados para viabilizar uma espécie de plataforma reformista fraca, experimentada como solução de governabilidade pela coalizão de poder que exerceu o governo no período. 
A análise do autor transposta ao campo da produção da habitação social no âmbito dos programas públicos federais encontraria um resultado compatível: política habitacional desvinculada da política urbana, regulação de crédito imobiliário favorável aos interesses do chamado mercado imobiliário, priorização da produção habitacional via contratação de empresas construtoras, dentre outras fragilidades.

A pesquisa traduz ainda a experiência acumulada pelo trabalho do autor como assessor jurídico da UMM/SP (União dos Movimentos de Moradia) e da UNMP (União Nacional por Moradia Popular) que, na qualidade de observador e ator privilegiado pode acompanhar diversos eventos da trajetória de uma das mais relevantes organizações portadoras da proposta autogestionária na moradia.

O percurso da pesquisa se inicia no Capítulo II com a recuperação do processo de institucionalização da proposta ao longo de sua transformação de experiência isolada em política pública embrionária nas experiências pioneiras, com destaque para o programa de mutirões autogestionário do Governo de Luiza Erundina de Souza, à época no Partido dos Trabalhadores, seu desenvolvimento e no período subsequente.

O Capítulo III busca relacionar os valores fundamentais que constituem os processos autogestionários, analisando criticamente o conceito de autogestão na moradia, seus elementos fundamentais (participação, ajuda mútua e finalidade não lucrativa) e sua relação com os outros processos sociais que the são próximos como os desafios das organizações da sociedade civil, da economia solidária e do cooperativismo habitacional.

O capítulo IV discutirá como os elementos constitutivos da autogestão foram incorporados e reformulados ao longo do desenvolvimento do PMCMV-E nas leis e regulamentos do programa e nas ações dos atores diretamente relacionados com o programa.

O Capítulo V busca, na forma de um "estudo de caso", estabelecer as relações entre os limites analisados e os eventos ocorridos nos empreendimentos habitacionais Florestan Fernandes e José Maria Amaral, desenvolvidos no âmbito do PMCMV - E, sob responsabilidade do Movimento dos Trabalhadores Sem Terra Leste 1, cujas cujo processo de produção (GUARITÁ, 2018; CAMARGO, 2016;) permite aferir - com relativa propriedade - quais os rebatimentos mensuráveis das tais limitações políticas e jurídicas referidas.

O capítulo VI trará as considerações finais. 
Trata-se, portanto, de uma pesquisa baseada na revisão bibliográfica, com ênfase nos documentos internos dos principais movimentos de moradia que atuam na área, complementada pelo estudo de caso de caráter explanatório relativo aos empreendimentos habitacionais Florestan Fernandes e José Maria Amaral.

O trabalho deve referência ao amplo conjunto de estudos acadêmicos que trataram do tema do mutirão e da autogestão na moradia, especialmente as contribuições de: BONDUKI, 1992; RONCONI, 1994; PAZ, 1996; FELIPE, 1997; AMARAL, 2001; ARANTES, 2002; CARVALHO, 2004, BARAVELLI, 2006; ACYOLI, 2009; NAIME, 2009; RODRIGUES, 2013; LAGO, 2012; LAZARINI, 2014; CAMARGO, 2016; VELASCO, 2017, dentre outros tantos textos relevantes, que, sem dúvida, contribuíram substancialmente para o registro da experiência autogestionária.

A pesquisa assume o risco de estudar um processo em curso e o faz negando a suposta neutralidade que deve informar o método científico e espera-se que disso, ao contrário de produzir um texto desprovido de caráter acadêmico, ao contrário, possa veicular uma noção suficientemente crítica capaz de contribuir com o necessário debate sobre os limites e desafios do processo de produção autogestionária no país. 


\section{2 - Do FUNAPS ao PMCMV-E: aspectos elementares dos arranjos institucionais.}

Este capítulo visa recuperar os elementos elementares dos arranjos institucionais ${ }^{1}$ dos principais programas de habitação social que se utilizaram de processos autogestionários no período equivalente ao delimitado para a pesquisa.

Os programas FUNAPS Comunitário e seu sucessores, desenvolvidos pela Prefeitura Municipal de São Paulo, o Programa de Mutirões UMM e o Programa Paulista de Mutirão, desenvolvidos pelo governo do Estado de São Paulo e os Programas Crédito Solidário, Produção Social da Moradia e o Programa Minha Casa Minha Vida - Entidades, ressalvadas suas especificidades, de acordo com os parâmetros usualmente utilizados nos estudos sobre políticas públicas ${ }^{2}$, constituem formas inovadoras ${ }^{3}$ de execução de políticas públicas no âmbito da política habitacional das diversas instâncias. São, sinteticamente, programas públicos paradigmáticos para a compreensão dos processos autogestionários. ${ }^{4}$

Admite-se, de início, que a mera análise dos aspectos institucionais, isoladamente considerados, não é suficiente para abarcar toda a complexidade que caracteriza a experiência autogestionária, entretanto, ao revés, desconsiderá-la tampouco tem utilidade para que se alcance uma abordagem completa do fenômeno. Não se trata, inclusive de constatação deste trabalho, mas de questão

\footnotetext{
${ }^{1} \mathrm{O}$ conceito de arranjo institucional no qual o texto se apoia é aquele sintetizado por (GOMIDE e PIRES, 2012) segundo o qual se entende por arranjos institucionais o conjunto de regras, organizações e processos que definem a forma como se coordenam os atores e os interesses em pauta em uma determinada política pública.

2 O texto se apoia no conceito de política pública desenvolvido por Bucci, 2006, p. 39 para quem "o programa de ação governamental que resulta de um conjunto de processos juridicamente regulados processo eleitoral, processo legislativo, processo de planejamento, processo administrativo e processo judicial - visando coordenar os meios à disposição do Estado e as atividades privadas, para a realização de objetivos socialmente relevantes e politicamente determinados".

${ }^{3}$ O termo inovação, de caráter polissêmico, será utilizado no sentido empregado por Farah (2006) designar as políticas públicas desenvolvidas a partir da década de 80 do século $\mathrm{XX}$, marcadas pela perspectiva de democratizar a ação pública, tanto do ponto de vista da ampliação da parcela com acesso aos serviços públicos, quanto da perspectiva dos processos de formulação, implementação e controle de políticas públicas.

${ }^{4}$ Não se desconhece o fato histórico de que no período do nascimento dos programas que serão analisados, também nasciam outras experiências altamente relevantes noutros Estados da federação, como constataram estudos consistentes como os realizados por: MOREIRA (), CONTI (1999), dentre outras ${ }^{4}$, mas, dado o recorte escolhido para a pesquisa, optou-se por destacar, do conjunto de programas que foram desenvolvidos no país ${ }^{4}$, aqueles localizados no Estado de São Paulo, dado que, além do caráter pioneiro, também são os que possuem o mais robusto conjunto de informações disponíveis para ampla consulta dos interessados.
} 
antiga posta como desafio a quem pretende investigar o tema. Para BONDUKI (2000, p. 43):

\begin{abstract}
"Na viabilização de um programa baseado na autogestão, a questão institucional é central, pois a resistência dos órgãos públicos em aceitar a perda do seu papel promotor é enorme. Aí reside o nó da questão: quando o FUNAPS de convenia com uma associação ou uma cooperativa para financiar, a administração pública este efetivamente dividindo parcela de seu poder com a sociedade organizada, deixando de ser promotora e passando a exercer apenas um papel de normatização, fiscalização e controle. E isso não é aceito por uma gama variada de correntes políticas, da direita e da esquerda, nem por grupos internos de poder, que microscopicamente se formam em órgãos públicos".
\end{abstract}

Trata-se de uma visão panorâmica da qual se espera que seja possível extrair os principais dilemas políticos e jurídicos que justificaram a tomadas das decisões que serão analisadas no Capítulo IV dessa dissertação.

\title{
2.1. 1980 - A década da participação popular.
}

A partir do final da década de 70 do século XX, conforme BONDUKI (2006, p. 229) com a tentativa de constituição de um campo dedicado a analisar no plano teórico os aspectos típicos dos processos de urbanização brasileira a partir da própria noção de urbano, firmaram-se estudos e diálogos relevantes que constituíram o marco referencial de interpretação nos fenômenos urbanos.

Assim, dentre outros aspectos, notou-se a relevância do problema e do falso problema da habitação popular com a proliferação de estudos pioneiros e cuja influência ainda hoje é objeto de debate relevante nos campos das ciências sociais, da geografia, do urbanismo, do direito, dentre outras áreas ${ }^{5}$.

Sinteticamente, quanto à estratégia de política de habitação então desenvolvida pelo Banco Nacional de Habitação no âmbito da Política Nacional de Habitação, é corrente que visava mais a enfrentar o problema econômico conjuntural de então, do que combater os problemas especificamente habitacionais.

Numa primeira etapa, a preocupação com a racionalização e a mecanização de processos de construção de grandes empreendimentos habitacionais concentrados em grande glebas de terras, em geral localizadas em regiões da

\footnotetext{
${ }^{5}$ Nesse sentido: OLIVEIRA (1972); CAMARGO, CARDOSO, MAZUCHELLI et. al. (1981); MARICATO (1979), dentre outros;
} 
extrema periferia das cidades, explicitaram a opção do sistema político no sentido de "escolher" as empresas de construção civil como parcerias privilegiadas em detrimento de outras possibilidades que, eventualmente, valorizassem a elaboração de projetos arquitetônicos de melhor qualidade, a participação dos usuários no processo de produção ou a articulação da política habitacional com a política urbana. Depois, Conforme ROYER (2002, p.12), no final da década de 70, diante da constatação de que os programas não atendiam os extratos de menor renda, o que gerava desgaste político ao governo e diante da impossibilidade de injetar mais recursos públicos no sistema, optou-se por buscar o barateamento dos custos de produção, por meio de programas específicos que incorporavam, dentre outras estratégias, a possibilidade de super-exploração da força de trabalho dos beneficiários com a utilização da autoconstrução.

O texto clássico de BOLAFFI, (1979, p. 46-70) dentre outros, além de identificar as principais deficiências do modelo, também buscou elencar um conjunto de estratégias urbanísticas que ao longo de seu desenvolvimento foram se constituindo com um conjunto de parâmetros ideais para a constituição de uma plataforma de reforma urbana.

FELTRAN (2017), em breve comentário à obra "A espoliação urbana”, de autoria de Kowarick, sintetizou a perversidade do modelo de desenvolvimento nos seguintes termos:

"na realidade, crescimento e pobreza realimentam-se em lógica positiva, presente, produtiva: nosso modelo de crescimento econômico e urbano é o mesmo modelo de reprodução da pobreza urbana. Crescimento (nesse modelo) é sinônimo de produção de pobreza".

$\cdots$

"Essas duas linhas do conflito urbano contemporâneo são mais nítidas quando a equação teórica da espoliação urbana nos oferece um diagrama e fundo para a compreensão conjunta das relações entre economia, política e produção do espaço urbano".

No plano da formulação de políticas urbanas locais, a síntese de ARRETCHE (1996, p. 75) permite uma primeira aproximação em relação ao balanço das políticas sociais naquele período. Para a Autora:

"O processo de redemocratização, o processo constituinte, as propostas de resgate da "dívida social", temáticas do cenário político brasileiro dos anos 80 , colocam em questão estes termos da relação 
entre "centro" e "periferia" do processo decisório. Neste contexto, a ideia de descentralização ganha força e conteúdo, seja porque está inserida no debate internacional sobre a reforma do Estado, seja porque está fortemente associada às expectativas de democratização do sistema político ou, finalmente, porque ao longo da década ensaiaram-se efetivamente movimentos no sentido de maior autonomia financeira para estados e municípios e da reterritorialização das decisões. "

E o contexto socioeconômico onde tais iniciativas se desenvolveram, ainda que contra majoritários, indicavam potencialmente o início de um processo de inovação na ação pública, que, conforme Farah (2006, p. 42), seria comparável a inauguração de uma nova etapa histórica, essencialmente marcada pela busca da superação das insuficiências do período imediatamente anterior:

"Dentre os fatores que conduziram à atribuição de uma crescente importância aos governos locais no período recente destacam-se: (i) a democratização e a ênfase conferida à descentralização na agenda democratizante, em decorrência da associação entre centralização e autoritarismo; (ii) a crise fiscal, que veio limitar a capacidade de ação do governo central, levando-se à incorporação, pelas elites locais da tese que defende a descentralização como instrumento de redução do tamanho do Estado e de ajuste fiscal; (iii) a globalização e redefinição do papel dos Estados nacionais, processos que acabaram por "transferir parcialmente" aos governos locais temas como o desenvolvimento e questão social".

Essa pretensa nova geração de políticas públicas buscava dar resposta à emergência de uma nova sociabilidade, impregnada pela percepção das novas possibilidades abertas no processo de redemocratização política, característico do período. Para STUCKY (1997, p. 52):

\footnotetext{
"Assim, pode-se dizer que as políticas públicas emergem de um contexto social, onde ocorre um jogo de forças, envolvendo os grupos econômicos e políticos, classes sociais e demais componentes da sociedade civil. Esse jogo de forças determina as decisões tomadas na esfera estatal. Determina igualmente a intervenções em uma dada realidade social e ou econômica, direcionando e ou redirecionando investimentos no âmbito social e produtivo da sociedade. O conjunto dessas decisões constitui a política de um determinado governo. Dessa forma, política pública é muito mais do que um conjunto de normas administrativas e burocráticas. Ela é uma manifestação de um jogo de forças, um conflito de interesses".
}

Sobre o estágio de desenvolvimento das políticas públicas executadas em âmbito local, especialmente nos governos de oposição ao governo central, 
acentuava-se o seu caráter descentralizado e participativo, no sentido de realçar o aspecto substancial do conceito de democracia na direção um Estado Democrático e Social de Direito.

Como tipo ideal, o Estado Social, analisado de acordo com a obra de BONAVIDES (2007, p. 186), afirma a existência de um tipo de Estado caracterizado pela prevalência da busca por valores como a dignidade da pessoa humana, a solidariedade, viabilizados a partir da instituição de novas constituições batizadas como programáticas, nas quais a concreção dos preceitos e regras garantidoras de direitos fundamentais.

Em termos democráticos, segundo o autor, o Estado social admite as bases capitalistas, constituindo-se, portanto, como sua própria metamorfose em relação ao antigo Estado Liberal. Basicamente, na busca da superação da contradição entre a igualdade política e a desigualdade social, surge, sob distintos regimes políticos, uma forma de mediação de conflitos sociais, um Estado pacificador entre o "trabalho" e o "capital". Em termos estritos:

\begin{abstract}
"que intervém na economia como distribuidor, dita o salário, que manipula a moeda, regula os preços, combate o desemprego, protege os enfermos, dá ao trabalhador e ao burocrata a casa própria, controla as profissões, compra a produção, financia as exportações, concede crédito, institui comissões de abastecimento, provê necessidades individuais, enfrenta crises econômicas, coloca na sociedade todas as classes na mais estreita dependência de seu poderio econômico, político e social, em suma, estende sua influência a quase todos os domínios que dantes pertenciam, em grande parte, à área de iniciativa individual."
\end{abstract}

Era o início no país de uma resposta organizada na forma de política pública, dado o descontentamento generalizado com a prática das iniciativas habitacionais anteriores eram amplamente rechaçadas. Nas palavras de BONDUKI (1992, p. 140):

"Quase todos os aspectos da política de habitacional foram questionados: mecanismos de financiamento, fontes de recursos, o caráter (anti) social dos investimentos, as intermediações, o processo de produção, a tecnologias adotadas, a dimensão dos conjuntos e seus projetos arquitetônicos e urbanísticos, as formas de propriedade, a gestão da política habitacional, o papel da iniciativa privada e do usuário, a centralização das decisões. Nem sequer a necessidade de um Banco de Habitação escapou desse debate onde críticas contundentes ao que vinha sendo feito, foram compartilhadas por quase todos os segmentos da sociedade". 
De modo que, alternativamente, especialmente nas grandes cidades, introduziram-se novas experiências constituintes de um novo campo. No dizer de Farah (2006, p. 46):

"A ênfase à participação na agenda democrática traduziu-se na proposição e instituição de mecanismos de formulação e gestão de políticas públicas baseados no envolvimento de representantes da sociedade civil, tais como conselhos de saúde e educação e o mutirão, a ajuda mútua e as cooperativas habitacionais, na área da habitação".

No plano da participação política, na cidade de São Paulo e possivelmente com repercussão nacional, no âmbito da democracia representativa, eram eleitos os primeiros governos progressistas marcados por uma perspectiva de ampliação de direitos e inclusão dos extratos sociais historicamente excluídos dos processos de formulação e execução de políticas públicas. SINGER analisou a conjuntura do período para entusiasmado afirmar (1996, p. 23):

"À medida que fracassavam os planos de estabilização e a
Constituinte incorporava à nova Carta Magna as principais
aspirações de setores organizados da sociedade brasileira, começou
um processo de polarização politica: enquanto o conservadorismo se
aglutinava ao redor do arco formado pelo PDS, PFL, PL e PTB, o
progressismo afluía em direção a um arco formado pelo PDT, PSDB
e PT, além de partidos menores. Esta polarização nasceu na própria
Constituinte mas passou a se alimentar dos antagonismos sociais
que a deterioração econômica exacerbava".

No plano da democracia direta, também havia um sentido inovador na participação das organizações representativas dos movimentos sociais no processo de ampliação do espaço democrático do país, tanto no plano da formulação de novas leis e, nesse sentido, o exemplo do processo participativo de elaboração da Constituição Federal é central, como nas políticas públicas.

A participação popular na formulação da Constituição merece destaque também pois indicava a abertura de novas perspectivas ao desenvolvimento social do país, já que chamada de Constituição Cidadã preconizava a adoção de um conjunto de fundamentos tendentes a construir um novo tipo de sociedade: soberania, cidadania, dignidade da pessoa humana, valores sociais do trabalho e da 
livre iniciativa e pluralismo político ${ }^{6}$ ou, conforme a leitura de FERREIRA (2018, p. 116), constituiu um momento de alegria na vida política do pais:

"o que se pretendia, por meio dessa participação, era assegurar uma definição, na nova Constituição, de direitos e deveres e de orientações das políticas públicas que atendessem os diferentes anseios do povo brasileiro, bloqueados durante o regime militar. E também obter a criação de instrumentos de democracia participativa e de democracia direta que dessem continuidade a essa participação, abrindo espaço para a contribuição corresponsável e criativa de toda a sociedade na busca democrática de soluções para os graves problemas enfrentados pelo Brasil".

No plano normativo, a participação no debate constitucional e os resultados positivos obtidos nos programas autogestionários das administrações progressistas, estimularam o amplo movimento cívico que buscou estruturar políticas capazes de reverter a injustiça premente das ações governamentais até então desenvolvidas, de modo que, logo após a promulgação da constituição, lançaram se os movimentos, seus técnicos e apoiadores a construir a campanha para a apresentação do primeiro projeto de iniciativa popular de lei, possível após o processo constituinte.

A Constituição estatui a noção de uma democracia participativa, fundada na ideia do estímulo à constituição de uma cidadania ativa. São explícitos nesse sentido, alguns dos artigos iniciais da Constituição:

Art. 1ํ A República Federativa do Brasil, formada pela união indissolúvel dos Estados e Municípios e do Distrito Federal, constituise em Estado Democrático de Direito e tem como fundamentos:

I - a soberania;

II - a cidadania;

III - a dignidade da pessoa humana;

IV - os valores sociais do trabalho e da livre iniciativa;

$\checkmark$ - o pluralismo político.

Parágrafo único. Todo o poder emana do povo, que o exerce por meio de representantes eleitos ou diretamente, nos termos desta Constituição.

$\cdots$

Art. 14. A soberania popular será exercida pelo sufrágio universal e pelo voto direto e secreto, com valor igual para todos, e, nos termos da lei, mediante:

I - plebiscito;

II - referendo;

III - iniciativa popular.

\footnotetext{
${ }^{6}$ Os fundamentos constitucionais da República estão elencados no artigo 1을 da Constituição Federal e anunciam, no plano normativo, os compromissos fundamentais pactuados no processo de redemocratização do país.
} 
Numa rápida aproximação com o debate sobre a efetividade das normas constitucionais, inicialmente é importante registrar a diferença conceitual entre texto legal e norma jurídica. Enquanto a primeira representa o texto da lei propriamente dito, construído no chamado processo legislativo e que possui como característica fundamental seu caráter abstrato, no segundo caso, temos a chamada norma jurídica, que, por sua vez, não é sinônimo de lei, de texto legal. Ao contrário, a norma jurídica consiste numa atividade de produção interpretativa.

Desse modo, a "disputa interpretativa" é o que dará contorno de efetividade ao texto legal. Em síntese: enquanto o texto legislativo é estático, a norma jurídica é dinâmica.

Considerada essa premissa inicial, note-se que foram introduzidas inovações que tiveram impacto relevante no processo de produção habitacional, dentre os quais se pode referenciar a elevação do ente municipal à condição de ente federativo, conferindo-lhe autonomia administrativa, financeira e política (art. 18), o estabelecimento das competências entre os níveis de governo no que se refere tanto à política urbana (art. 182 e 183), quanto à promoção de programas de construção de moradias e à melhoria das condições habitacionais e de saneamento básico (art. 13), posteriormente complementadas pela inclusão expressa do direito a moradia dentre os chamados direitos sociais ${ }^{7}$.

Desse conjunto de previsões, nascem obrigações positivas - no sentido da exigibilidade imediata do desenvolvimento de políticas públicas necessárias à viabilização de programas e ações habitacionais - ou negativas no sentido de que a norma jurídica ou mesmo a ação material contrária ao dever constitucional do Estado é natimorta.

Em sua consagrada sistematização sobre a eficácia e aplicabilidade das normas constitucionais, lastreada na doutrina italiana, SILVA (1998, p. 117) elucida a capacidade de condicionamento que têm as normas constitucionais; mesmo aquelas classificadas como de "eficácia limitada", exatamente as que ficam a aguardar futura lei sobre o assunto, se prestam, pelo menos, a submeter um indivíduo, o Estado, a

\footnotetext{
${ }^{7}$ Ausente do texto original o tema foi inserido por meio da Emenda Constitucional $n$ 2000. Também em 2000, foi instituído, mediante aprovação da Emenda Constitucional no 31 , o Fundo de Combate e Erradicação da Pobreza, cujos recursos serão, em parte, também destinados às ações suplementares na área de habitação (art. 79, do Ato das Disposições Constitucionais Transitórias).
} 
uma abstenção: a de não atentar por leis ou atos contra os princípios ou normas programáticas ali contidas, porque indicam os fins sociais a que se dirigem o Estado. Todos esses pontos convergem para, de modo mais específico, a Constituição da República definir como competência comum da União, dos Estados, do Distrito Federal e dos Municípios a promoção de programas de construção de moradias e a melhoria das condições habitacionais.

Como decorrência desse conjunto de inovações, onze anos depois, foi aprovada a Lei Federal no 10.257/2001, autodenominada "Estatuto das Cidades", que regulamenta os arts. 182 e 183 da Constituição Federal e estabelece diretrizes gerais da política urbana, dentre as quais se destacam:

Art. $2^{\circ} \mathrm{A}$ política urbana tem por objetivo ordenar o pleno desenvolvimento das funções sociais da cidade e da propriedade urbana, mediante as seguintes diretrizes gerais:

I - garantia do direito a cidades sustentáveis, entendido como o direito à terra urbana, à moradia, ao saneamento ambiental, à infraestrutura urbana, ao transporte e aos serviços públicos, ao trabalho e ao lazer, para as presentes e futuras gerações;

II - gestão democrática por meio da participação da população e de associações representativas dos vários segmentos da comunidade na formulação, execucãa e acompanhamento de planos, programas e projetos de desenvolvimento urbano;

III - cooperação entre os governos, a iniciativa privada e os demais setores da sociedade no processo de urbanização, em atendimento ao interesse social;

Ao analisar tais diretrizes gerais, o jurista Carlos Ari Sundfeld (2010, p. 68), afirma que:

\begin{abstract}
"Historicamente, o princípio representativo surgiu como a primeira das respostas aos reclamos de controle democrático sobre a atuação estatal. Confiava-se que a combinação da legalidade (exigência prévia de autorização legal para a ação do Poder Público) e com o caráter democrático da composição do parlamento - a isso somando-se a eleição direta do Chefe do Poder Executivo - seria suficiente para impedir que o Estado de fechasse em si mesmo. Entretanto, não só a experiência mostraria que as coisas não seriam simples assim, como o aprofundamento da atuação estatal, inclusive normativa, viria a exigir novos mecanismos de abertura, incluindo-se a participação popular direta em decisões legais e administrativas, além da interferência de entidades representativas de segmentos da população".
\end{abstract}

Frise-se que a diretriz impõe que um tipo de controle social mais abrangente do que a mera participação dos cidadãos no exercício do poder colocando a vontade social como fator de avaliação para a criação e metas a serem alcançadas no âmbito de algumas políticas publicas. O que está positivado é o direito dos cidadãos, 
diretamente ou por meio de suas entidades representativas, exercer tais funções e, além disso, executar programas urbanísticos.

Além disso, a Constituição também reconheceu o direito social fundamental à moradia, qualificou o direito de propriedade atribuindo-lhe o dever de cumprir uma função social (Art. 5, inciso XXIII) e, finalmente estatuiu como direitos difusos ${ }^{8}$ os decorrentes na nova ordem urbanística vigente.

Tais avanços institucionais se deram no âmbito do processo histórico de retomada de um movimento nacional por uma reforma urbana no país que tem como referenciais fundamentais, a reformas de base consolidadas no Seminário de Habitação e Reforma Urbana, organizado pelo Instituto dos Arquitetos do Brasil em 1963 e o processo de elaboração e discussão da chamada emenda popular da reforma urbana, desenvolvido no processo constituinte de 1987-1988. Para Saule e Uzzo (2009):

\begin{abstract}
"A principal bandeira da reforma urbana se consolida: o direito á cidade, que se caracteriza pela gestão democrática e participativa das cidades; pelo cumprimento da função social da cidade; pela garantia da justiça social e das condições dignas a todos os habitantes das cidades; pela subordinação da propriedade à sua função social; e pelas sanções aos proprietários nos casos de não cumprimento da função social".
\end{abstract}

No que diz respeito aos processos de produção habitacional por mutirão e autogestão, essa reflexão acadêmica e o processo social interagiram e influenciaram a concretização da defesa por parte das organizações populares de modelos alternativos, dentre os quais o da produção por mutirão com autogestão.

A existência de uma legislação que valida e eventualmente incentiva a produção de habitação com participação da sociedade na solução dos problemas habitacionais não implica, na aceitação geral de tais valores que permanecem submetidos ao conflito persistente em setores da sociedade que buscam a implementação dos direitos sociais por meio da constituição de políticas públicas destinadas à constituição da justiça social e do bem comum e aqueles que desejam a prevalência dos interesses dos setores empresarias financeirizados que se valem do Estado para viabilizar interesses exclusivamente privados.

\footnotetext{
${ }^{8}$ A classificação do instituto jurídico dos direitos difusos é dada pelo parágrafo único do artigo 81 da Lei Federal no 8.078/90, conhecida como Código de Defesa do Consumidor que os classificam como sendo os direitos ou interesses de natureza transindividuais, indivisíveis, dos quais sejam titulares pessoas indeterminadas e ligadas por circunstâncias de fato.
} 
Não se trata de aspecto conjuntural, mas estrutural do processo político onde os projetos habitacionais se desenvolvem, que nas palavras de um dos mais relevantes juristas brasileiro, demonstram a persistência do que qualificou como um dualismo funcional, ou seja, a prevalência de uma índole conservadora que permite uma dissociação entre o direito posto - a regra - e o direito vivido, o cotidiano que ignora ou altera a regra, contra a qual é necessário contraposição permanente (COMPARATO, 2009, p. 9). Diz o Autor:

\footnotetext{
"a dualidade funcional do direito brasileiro deita raízes históricas em longa tradição, no quadro de um sistema de poder fundamentalmente oligárquico. Sua permanência ao longo dos séculos forjou um complexo de costumes e uma mentalidade social de índole francamente conservadora".
}

O processo histórico de viabilização dos projetos de habitação de mutirão com autogestão se desenvolvem nesse contexto, buscando superar resistências que cuja plausibilidade não se depreende numa análise inicial, dado que, em princípio, são ações necessárias dentre o conjunto de daquelas passíveis de constituição de uma política habitacional eficaz.

Portanto, nesse cenário, desenvolveram-se os pilares fundamentais da proposta de construção de moradia em regime de mutirão com autogestão: mobilização social aliada à disposição para a construção de uma política pública razoavelmente estruturada e comprometida com a transformação do padrão excludente das cidades.

\subsection{Agentes dos processos de mutirão autogerido}

A constituição de programas de mutirão com autogestão que sucederam o processo constituinte se inseriam nesse contexto de busca de políticas públicas mais efetivas e foi estruturado a partir do triple constituídos por movimentos sociais de moradia organizados sob a forma de associações civis ou cooperativas habitacionais, assessorias técnicas especializadas e agentes públicos com função política no âmbito da administração.

Ao longo do desenvolvimento histórico dos programas, todos os entes sofreram modificações relevantes. Sem dúvida, de início, pode ser dizer que a atuação desses agentes e entes influenciou positivamente na compreensão da proposta autogestionária. 


\subsubsection{Os movimentos de moradia}

Assume-se como relativamente consensual da análise da literatura do período, a noção de um ressurgimento noutras bases, de uma nova espécie de movimentos sociais, comumente referida pelos pesquisadores sociais como "novos movimentos sociais".

$\mathrm{Na}$ cidade de São Paulo, os movimentos de moradia tem como referência simbólica as ocupações de terras ocorridas em 1981 na gleba denominada "Fazenda Itupu" (BONDUKI, 1986; MUÇOUÇAH e ALMEIDA (1991); CARVALHO (2004); IFFLY (2010) et. al, que possuiu uma força de irradiação capaz de influenciar diversos grupos nas periferias na cidade ${ }^{9}$.

Ao analisar o fenômeno geral das primeiras articulações dos movimentos sociais como um todo, RICCI, (2010, p. 178) indica que na literatura sociológica inovadora e majoritária do período ${ }^{10}$, a novidade de tais sujeitos políticos estaria basicamente representada no seu caráter autônomo, anti-institicional, marcado pela tentativa de superação dos movimentos sociais de outrora, conhecidos por suas vinculações às estruturas partidárias da esquerda vinculadas ao chamado socialismo real, cujo principal referência seria o modelo soviético.

De meras "correias de transmissão" de partidos e sindicatos, os novos movimentos sociais seriam portadores de um verdadeiro programa de ação inspirado nas noções de solidariedade e comunitarismo, tendo o "pobre" sido elevado à categoria sociológica portadora de um novo modelo de sociedade. Ainda segundo o autor, citando a referência dos estudos de llse Sherer Warren, os elementos de identidade desses novos movimentos estavam baseados na democracia de base, na livre organização, na autogestão, no direito à diversidade, no respeito à individualidade, na identidade local-regional, e na liberdade individual associada à liberdade coletiva.

\footnotetext{
${ }^{9}$ No período, ficaram registradas como pioneiras as ocupações do terreno da Record, a ocupação da Vila $1^{\circ}$ de Outubro no extremo da zona leste, a ocupação do Jardim Filhos da Terra, na zona norte, dentre outras.

${ }_{10} \mathrm{O}$ autor inclui entre os autores de referência para a compreensão do período os seguintes pesquisadores: Maroni (1982), Sader (1988); Abramo (1985); Sherer-Warren; Krischke (1987); Rodrigues (1990); Antunes (1991); Moisés (1982); Almeida (1975); Sola e Paulani (1995); Landim (1998); GONH (1997); Dagnino (1994); Ricci (1999).
} 
No caso dos movimentos de moradia, havia uma peculiaridade. Além de seu caráter autônomo, desde sempre, também estavam presentes reivindicações direcionadas ao poder público que buscavam a construção de políticas públicas efetivas e caracterizadas pelo protagonismo dos futuros moradores. Para GOHN (1991, p. 61), uma das pioneiras na busca por uma teorização acerca dos movimentos sociais, particularmente aos movimentos de moradia poderia se identificar como suas vertentes preponderantes: (i) moradores de favelas, que lutavam por água e luz; (ii) e os movimentos vindos das lutas das casas precárias autoconstruídas de periferia, buscando condições de infraestrutura ou lutando pela propriedade dos lotes clandestinos ou grilados.

Posteriormente, sob influências diversas, dentre as quais a dos agentes pastorais vinculados à teologia da libertação ${ }^{11} \mathrm{e}$ dos profissionais ligados à proposta de renovação da política urbana organizados em torno do ideário da reforma urbana, num processo simbiótico, amplia-se o repertório de todos as partes envolvidas.

A autora, (ob. cit., p. 64), relaciona um conjunto de elementos característicos dos movimentos sociais de moradia do período: (i) agrupam uma grande quantidade de moradores de aluguel; (ii) possuem experiência anterior de organização nos bairros; (iii) reivindicam outra situação habitacional, alternativa ao modelo vigente, baseada no trabalho coletivo; (iv) parte da luta da terra; (v) reivindicam recursos públicos; (vi) buscam o apoio de entidade de assessoria técnica; (vii) alternam reivindicações ao Estado com processos internos de formação e capacitação; (viii) introduzem um novo componente político na medida em que aliam a luta por moradia com a busca da construção de uma nova via para a solução dos problemas; (ix) são propositivos e se credenciam como interlocutores dos agentes públicos; ( $\mathrm{x}$ ) aliam o saber advindo da prática cotidiana com o saber técnico.

Além das grandes mobilizações sociais que caracterizaram os movimentos sociais urbanos nos anos 80 , diversos autores tem pontuado que, no período seguinte, as organizações estabeleceram uma articulação entre as reivindicações pontuais e específicas das comunidades locais e com as agendas mais amplas ligadas ao direito à Cidade.

\footnotetext{
${ }^{11}$ De forma sintética, pode-se definir a Teologia da Libertação, conforme a noção desenvolvida por Gutierres (1973) como uma corrente teológica cristã nascida na América Latina, depois do Concílio Vaticano II e da Conferência de Medellín, organizados pela igreja católica que parte da premissa de que o Evangelho exige a opção preferencial pelos pobres ao mesmo tempo em que reconhece seu protagonismo no processo de mudança social e participação política.
} 
Embora a prática de encontros acompanhasse os movimentos de moradia desde o início da década de 80, articulados majoritariamente no nível local, (BONDUKI, 1992, ob. cit. p. 51), e dos encontros entidades de caráter nacional de representação dos movimentos, os fóruns estabeleceram a prática de encontros nacionais em larga escala gerando grandes diagnósticos dos problemas sociais, assim como definindo metas e objetivos estratégicos para combatê-los.

Novamente recorrendo a GOHN (2000), é possível afirmar que:

"A partir de 1990, ocorreu o surgimento de outras formas de
organização popular, mais institucionalizadas - como a constituição
de Fóruns Nacionais de Luta pela Moradia, pela Reforma Urbana:
Fórum Nacional de Participação Popular, etc. Os fóruns
estabeleceram a prática de encontros nacionais em larga escala
gerando grandes diagnósticos dos problemas sociais, assim
definindo metas e objetivos estratégicas para combate-los. Emergiam
várias iniciativas de parceria entre a sociedade civil organizada e o
Poder Público, impulsionando políticas estatais como a experiência
do Orçamento Participativo"

Emergiram várias iniciativas de parceria entre a sociedade civil organizada e o poder público, impulsionadas por políticas estatais tais como a experiência do Orçamento Participativo, a política de Renda Mínima, bolsa/escola, dentre outras.

A atuação dos movimentos de moradia na busca de implementação de políticas públicas não raramente é interpretada como se fosse limitadora ou contraditória à realização daquelas de caráter mais geral que marcaram a década de oitenta. No entanto, não é essa a visão que prepondera, entre as lideranças das organizações mais relevantes do movimento de moradia, para quem é preciso aliar a luta social com a capacidade propositiva do movimento.

Os mecanismos pelos quais os movimentos buscavam a construção dessas políticas (apresentação de propostas de projeto de lei, eleição de parlamentares, participação em conselhos de políticas públicas, participação das lideranças nos governos) foram identificados como limitadores da autonomia característica dos movimentos e o resultado disso, nas palavras de RICCI (ob. cit. p. 188) gerou certa perda de vitalidade das perspectivas introduzidas pelos chamados novos movimentos sociais. Para o autor, o dilema poderia ser resumido como uma contradição entre o discurso anti-institucionalista no qual se formaram as lideranças dos anos de 1980 e a necessária capacidade de formulação e gestão de políticas públicas colocado na década seguinte. Para o autor: 


\begin{abstract}
"O processo de institucionalização não ocorreu no tempo hábil para a elaboração gradativa de desenvolvimento econômico e institucional alternativo (como esperavam os estudiosos dos movimentos sociais de então) ao vigente. O inusitado dessa situação estabeleceu um vazio de formulação no que tange à institucionalidade pública, fruto da crítica ao presente sem projeção de sua superação."
\end{abstract}

Finalmente, o mesmo fenômeno, na abordagem de ABERS, SERAFIM E TATAGIBA (2014, p. 331), pode ser analisado na perspectiva das interações entre o os movimentos e Estado que não estão caracterizadas na centralidade do conflito. Para as autoras:

\begin{abstract}
Mas, como notam Abers e von Bülow (2011), o caso brasileiro desafia esta concepção pela contínua atuação dos movimentos no interior do Estado e a partir da forte interação com agentes públicos, sobretudo em cenários nos quais se identifica compartilhamento de projetos políticos (Dagnino, 2002). As autoras lembram que, no caso brasileiro, a própria criação de movimentos importantes resulta de alianças entre indivíduos dentro e fora do Estado, o que coloca em xeque a visão do Estado como contraponto o movimento. Isto faz com que seja necessário não apenas "teorizar sobre como os movimentos sociais constroem vínculos de colaboração com o Estado", mas também "como às vezes movimentos sociais buscam alcançar seus objetivos trabalhando a partir de dentro do aparato estatal" (Abers e von Bülow, 2011:78).
\end{abstract}

A premissa assumida nessa pesquisa é a de que, longo de caracterizar uma limitação, as relações entre os movimentos de moradia e o Estado se dá a partir de um conjunto de parâmetros dentre os quais coexistem: (i) a mobilização constante, qualificada na literatura especializada como ação direta; (ii), a apresentação de reivindicações de maior ou menor grau de especificação conforme a etapa histórica analisada; (iii) a busca por incidência na formulação das políticas públicas; As consequências tais fenômenos poderão ser aferidas no grau de incorporação das propostas em cada formato de programa habitacional que será analisado.

Os movimentos sociais de moradia que atuaram nos primórdios dos programas habitacionais, de modo geral, estavam organizados sob a forma jurídica de associações civis sem fins lucrativos. Não apenas isso. Necessariamente, por força das regras dos programas, eram constituídas associações de futuros moradores para a gestão dos convênios que viriam a ser celebrados.

Desse modo, foram estimuladas a criação de uma centena de associações que reuniam grupos relativamente pequenos, em geral, em quantidade muito próxima da quantidade de unidades que viriam a ser construídas. 
De um lado, a constituição de associações de futuros moradores permitia a expansão da experiência da gestão de projetos para um número maior de lideranças, atendendo ao objetivo de permitir o controle dos recursos pelos diretamente interessados. Por outro lado, a consolidação de uma rede de movimentos capaz de articular as demandas específicas de cada grupo com as demandas estratégicas dos movimentos dependia da construção de acordos políticos, entre as lideranças "de base" e as "coordenações dos movimentos" que exigiam um esforço demasiado.

A necessidade de constituição de estatutos sociais próprios, inscrição na Receita Federal e demais órgãos de controle da administração pública trouxeram a necessidade de uma especialização significativa das entidades, que além da mobilização cotidiana, também deveriam se amoldar aos procedimentos burocráticos da administração pública.

\subsubsection{As assessorias técnicas}

Outro elemento característico da formação dos movimentos de moradia vinculados à produção autogestionária da moradia foi o estabelecimento de relações permanentes com entidades de assessoria técnica especializada ${ }^{12}$.

GOHN (1991, p. 65) qualifica as entidades de assessoria técnica como um grupo de indivíduos, não pertencentes à base demandatária do movimento, que se articulam com o objetivo de subsidiar os grupos populares em sua organização interna e no encaminhamento de suas ações externas. Necessário acrescer a definição que se tratavam também de grupos com profissionais de diversas áreas de conhecimento, marcando o caráter interdisciplinar da atuação dessas organizações.

Embora de origem externa no sentido de que eram constituídas por profissionais ou estudantes universitários oriundos, em geral de classes medias, tais grupos estavam longe de se constituir como um elemento "acessório" no sentido vulgar, ou seja meramente secundário. Desde o princípio se caracterizam como agentes constituintes dos processos autogestionários de produção de moradia. São, nas palavras de LOPES (2018, p.140), técnicos-políticos. São constituintes no

\footnotetext{
${ }^{12}$ Este trabalho adota a expressão "assessoria técnica", pelas razões detalhadas em Cardoso e Lopes (2019) que em síntese, registram o uso seu uso majoritário entre os movimentos de moradia e sua contextualização ao longo do desenvolvimento histórico das propostas autogestionárias.
} 
sentido de alargar o repertório aportando o conhecimento técnico à cultura popular, mantendo, entretanto, independência em relação aos quadros das entidades, ressalvadas algumas experiências de assessoria técnica orgânica dos movimentos ou prestada isoladamente por algum profissional autônomo. ${ }^{13} \mathrm{O}$ escopo do trabalho que prestavam, para além da perspectiva eminentemente técnica, representava uma busca por um novo significado político e educativo peculiar à própria condição profissional. Para LOPES (ob. cit., p. 241):

\begin{abstract}
"Boa parte das formulações que embaralhavam o trabalho técnico e a militância política, dos projetos urbanísticos e arquitetônicos que se estendiam para além de seus limites estritamente construtivos, dos debates e práticas conduzidos e construídos entre muitas dificuldades ao longo dos anos 1980 e começo dos 1990, alimentava um imaginário que nos fazia crer nas possibilidades e potencialidades transformadoras das práticas autonomistas atreladas àqueles processos de produção da moradia. Como a polia na correia de transmissão, tais práticas fariam construir a "consciência da autonomia", estendendo os pressupostos de uma "gestão autônoma da vida" para outros âmbitos da produção e reprodução da existência".
\end{abstract}

$\cdots$

Assim como aparecia em seus contornos, esse discurso permitia imaginar que, após construída a moradia, abrigados os corpos e instalados os desejos particulares sob o teto produzido coletivamente e a partir do esforço próprio, aqueles construtores haveriam de alcançar também a construção de uma "consciência de autonomia", uma espécie de "desejo autodeterminado de autodeterminação", negando a submissão a um poder que lhes é externo, que não emana de si mesmos, e tomariam para si a construção livre e autônoma de sua própria existência.

CARVALHO (1995, p. 60) ao analisar a literatura sobre as origens dos grupos de assessoria técnica afirma, que seus antecedentes históricos remontam à década de 50 do século passado, representavam um início de atuação desses profissionais em direção às periferias da cidade, a partir de ações individuais, de escritórios modelos, de projetos pilotos do Sindicato dos Arquitetos e se consolidaram a partir dos Programa de Mutirões com recursos do FUNAPS ${ }^{14}$.

Em termos legais, também as assessorias técnicas, com o desenvolvimento do processo, foram se instituindo como sociedades civis sem fins lucrativos (equivalentes às atuais associações civis sem fins lucrativos) - ainda que muitas

\footnotetext{
${ }^{13}$ A CEP - Central de Entidades Populares é uma assessoria técnica formada por profissionais de arquitetura e urbanismo que pode ser considerada uma exceção à regra, na medida em que se constitui com um grupo identificado prioritariamente com a atuação do Movimento Sem Terra Leste II, uma das entidades pioneiras da luta da moradia.

${ }^{14} \mathrm{O}$ trabalho do autor reconstrói de forma detalhada a história, relaciona um conjunto amplo de iniciativas e nomeia as principais organizações de assessoria técnica, suas estruturas e funcionamento que se estruturaram a partir dos projetos de mutirão com autogestão.
} 
vezes com uma dinâmica interna próxima a de uma cooperativa - e a forma de relação jurídica com as entidades variava da relação informal, baseada em compromissos políticos comuns, passando pela elaboração de termos de colaboração, ou mesmo do estabelecimento de contratos de prestação de serviços com obrigações recíprocas, em termos que mesclavam aspectos políticos com a necessária remuneração pelo trabalho profissional.

Ao longo do desenvolvimento do processo, as Assessorias técnicas ficaram submetidas a toda ordem de inseguranças, desconstituídas e ameaçadas especialmente pela descontinuidade dos recursos financeiros que dificultaram ou inviabilizaram a sua atuação.

O período do Programa de Mutirões com autogestão com recursos do FUNAPS, reservou recursos específicos para os projetos e estimulou a criação de dezenas de grupos de assessoria técnica, mas, no sentido inverso, a desmobilização do programa que se sucedeu, também implicou no encerramento das atividades de dezenas delas. Entretanto, no período, alguns avanços institucionais merecem registro e alguns desafios surgiram e se relacionam com a pesquisa:

a) O caráter político-educativo da atuação - Ressalvadas as naturais diferenças ideológicas e históricas, seguimos a noção esboçada por PERCASSI (2009) que entendemos aplicável à maioria dos casos, segundo a qual os processos de formação realizados a partir da interação das lideranças dos movimentos de moradia com os agentes das assessorias técnica buscam implementar um processo de formação baseado em princípios que diferem a mera atuação assistencialista que se queria combater a partir dos valores autonomistas que prevalecem no discurso e na prática das principais organizações de luta por moradia. A presença nos processos de planejamento das ações de confronto e nos eventos de capacitação, nos seminários, debates, cursos de formação política, materiais de apoio, atualmente inclusive veiculados por meio eletrônico, inclusive permitiram a constituição de um acervo significativo das experiências autogestionárias ${ }^{15}$;

\footnotetext{
${ }^{15}$ Como exemplo, podemos citar o projeto "Fortalecimento e Difusão da Produção Habitacional por Autogestão", desenvolvido pela União Nacional por Moradia Popular, com apoio da Fundação Ford, que, dentre inúmeras outras ações, mantém um sitio eletrônico robusto com um conjunto de materiais de apoio à luta da autogestão na moradia. O acervo está disponível no endereço:
} 
b) A natureza não lucrativa da atividade - $O$ direito à assessoria técnica pode representar um contraponto substantivo à ideia de arquitetura autoral e exclusiva, majoritária nos meios profissionais da arquitetura e própria das relações capitalistas de produção. Integra, inclusive, o conteúdo do chamado direito a moradia, inscrito na Constituição Federal. Entretanto, sua viabilização depende da operacionalização que será dada no desenvolvimento de programas públicos de habitação ou da constituição de fundos privados dedicados ao desenvolvimento dessa atividade. Recentemente, conforme constataram CARDOSO e LOPES (2019), algumas iniciativas assemelhadas às assessorias técnicas têm sido desenvolvidas por pequenas empresas que atuam com finalidade lucrativa buscando obter recursos diretamente dos destinatários de seu trabalho. Ou seja, diante da insegurança dos processos desenvolvidos pelo Estado e Associações, outras estratégias de financiamento passaram a ser desenvolvidas, trazendo mais elementos de mercado a uma operação que se pretendia idealmente como não mercantil.

a) O caráter interdisciplinar do trabalho - Por se tratar de um trabalho promovido por arquitetos urbanistas, há, logicamente, uma prevalência desses profissionais nas equipes de assessoria técnica (CARVALHO, ob. cit. p.64-65). No entanto, desde os primórdios, há a busca pela constituição de um "arquiteto social" e de outros profissionais indiretamente vinculados ao processo de elaboração de um projeto. Desse modo, o trabalho de assessoria técnica é composto pela ação do arquiteto em harmonia com engenheiros de diversas especialidades, biólogos, geógrafos, advogados, sociólogos, pedagogos, assistentes sociais e outros profissionais. Embora se possa ressalvar que os processos são heterogêneos e disso decorra um grau maior ou menor de efetividade da atuação das assessorias técnicas, o que se pretende destacar nesse tópico é apenas e tão somente o fato de que esse tipo de atuação sempre esteve sujeito a pressões relacionadas ao seu caráter técnico-político e as deficiências das formas de financiamento que permanecem presentes na dinâmica dos processos.

A necessidade de garantir estabilidade aos processos de assessoria técnica na cidade de São Paulo gerou a elaboração de uma Lei Municipal de assessoria 
técnica. A Lei Municipal no 13.433/2002, de autoria do então vereador Nabil Bonduki, reconhece a atividade de assessoria técnica como um serviço público, de caráter amplo e multidisciplinar (no sentido de abarcar atividades de diagnóstico situacional, levantamentos fundiários e ambientais, estudos de viabilidade, documentação legal para a propositura de projetos urbanísticos, trabalho social e ambiental, acompanhamento para a execução de obras e promoção de atividades de formação, educação popular, cultura, educação ambiental e promoção de cidadania, direitos humanos e inclusão social, destinado ao atendimento da população em geral, mas priorizando $o$ atendimentos de projetos desenvolvidos por movimentos de moradia. A Lei se estrutura em consonância com as diretrizes do Estatuto das Cidades e do direito à moradia digna. $\mathrm{O}$ modelo imaginado prevê a assessoria integrada a um programa público de habitação, vinculada à princípios de integração da administração pública. Ela procura refletir os valores que ficaram fixados a partir da experiência do Programa Mutirões com recursos do FUNAPS, e determina a participação direta dos usuários em todas as etapas de elaboração do projeto. Basicamente, o procedimento de execução da Lei repete aqueles formulados na época do FUNAPS Comunitário, explicitando, entretanto, mecanismos públicos de seleção de entidades e direcionados exclusivamente ao fortalecimento de entidades sem fins lucrativos. A Lei foi regulamentada pelo Decreto Municipal o 43.592/2003. No entanto, mesmo depois vencido o processo legislativo e regulamentar, jamais foi efetivamente aplicada. Permanece no horizonte, como um direito não realizado, como tantos outros no campo da política habitacional.

Também como decorrência dos processos de luta por uma arquitetura pública e destinada à implementação do direito à moradia, após ao menos três décadas de mobilizações, foi aprovada a Lei Federal no 11.888/2008 que assegura às famílias de baixa renda assistência técnica ${ }^{16}$ pública e gratuita para 0 projeto e a construção de habitação de interesse social.

Algumas iniciativas decorrentes da aprovação dessa lei merecem registro como: (i) a criação de um programa público em nível federal de financiamento de iniciativas de assistência técnica no âmbito do extinto Ministério das Cidades; (ii) a profusão de leis Municipal de Assistência Técnica por Estados e Municípios; (iii) a criação de linhas privadas para o financiamento de atividades de assistência técnica;

\footnotetext{
${ }^{16}$ Note-se, que, nesse caso, prevaleceu a denominação assistência técnica em detrimento de assessoria técnica, de modo que, em princípio,
} 
(v) a profusão de Leis locais de assistência técnica; e: (vi) a realização de Seminários técnicos para a discussão do tema.

O debate sobre o escopo do trabalho de assessoria técnica continua vigoroso no país, como demonstram os numerosos artigos científicos elaborados como contribuição ao tema. Entretanto, seu lugar no processo de produção autogestionária, historicamente construído merece ser destacado de forma corriqueira pois interfere diretamente no resultado concreto de cada projeto habitacional. As pressões decorrentes da precarização dessa forma de trabalho constituem-se como um elemento de tensão na configuração dos projetos autogestionários.

\subsubsection{As assessorias jurídicas e o papel dos advogados populares.}

As ocupações urbanas realizadas por movimentos populares, ou mesmo de forma relativamente "espontâneas", ou seja, independentemente de uma organização prévia, ocorridas no início dos anos 80 eram uma das formas de acesso à terra dentre um contexto conflituoso no qual conviviam com os loteamentos irregulares, as favelas que se instalavam nas áreas verdes dos loteamentos regulares ou por meio da precariedade da vida nos cortiços.

A resposta dos proprietários, grileiros e do Poder Público, de modo geral, introduziam os processos de judicialização das disputas pela terra por meio de ações judiciais onde se discutia a quem pertenceria o direito da posse da terra, a aplicabilidade ou a nulidade das cláusulas contratuais que regulavam as relações civis imobiliárias, dentre outros aspectos.

No caso de São Paulo, vale a pena ressaltar os contornos específicos próprios do contexto, que no plano da luta política, estavam representados nas formas de resistência ao regime militar que por consequência implicava na luta pela redemocratização que passava, inclusive, pela aproximação com os movimentos sociais.

Assim vai se formando o cenário no qual as grandes mobilizações sociais de redemocratização, como as campanhas sindicais do final dos anos 70 , as mobilizações por democracia que culminaram a campanha por eleições diretas, convive, alimenta e se retroalimenta do trabalho de base, realizado nas periferias. Entrelaçaram-se a luta por direito individuais com a luta por direitos sociais para as 
periferias da cidade. PAZ, (1996, p. 58) personagem e pesquisadora do período, registrou que:

"Nesse momento de criação da UMM-SP, evidencia-se também a atuação de assessores e apoios profissionais que não são considerados agentes externos, mas "de dentro" dos movimentos sociais, com legitimidade construída no acompanhamento sistemático das questões locais, como as ocupações, enfrentamentos com o aparelho estatal e a repressão policial, manifestações e reivindicações; e assumem papéis de coordenação e direção política, como as de Miguel Reis Afonso, Rildo Marques de Oliveira, Wilson Bueno, todos da área jurídica, e a do atual vereador Henrique Pacheco, do Partido dos Trabalhadores, que durante vários anos desenvolveu trabalhos de assistência jurídica na região oeste da cidade".

Em depoimento direto ao Autor, Miguel Reis Afonso, advogado popular com atuação reconhecida na organização dos movimentos populares, comenta o início do trabalho dos estudantes de Direito e advogados que se dispunham a apoiar a luta popular então incipiente:

"Nos idos, de 1978, éramos estudantes de direito, que a partir da atuação política do Centro Acadêmico 22 de Agosto da PUC/SP, especialmente a partir da militância que já era realizada por outros estudantes do curso, dentre os quais, Antônio Sampaio, Bruno Blecher e Henrique Pacheco, dentre outros do grupo que se autodenominava "Opinião" ${ }^{17}$, começamos a participar de um grupo no interior do Centro Acadêmico e com forte articulação com a Arquidiocese de São Paulo da Igreja Católica, dedicado a prestar assistência jurídica gratuita em bairros periféricos em articulação com as organizações de base. $\mathrm{Na}$ época, alcançadas pelo desemprego ou por baixos salários, o operariado era influenciado pelo renascimento do chamado novo sindicalismo, pela ação pastoral da igreja católica e por lutas anteriores como os movimentos de saúde. Assim, além das reinvindicações econômicas, também haviam mobilizações por asfalto, água, energia elétrica nos bairros. No início era um atendimento tipo "clínica geral" para os casos de violência doméstica, conflitos familiares, ações criminais, relações contratuais, elaboração de estatutos sociais e contra as ações judiciais de despejos, ainda sob uma lei do inquilinato claramente favorável ao interesse dos proprietários."

${ }^{17}$ Formado nos idos de 1976, o grupo "opinião" era uma corrente política do movimento estudantil, que se pautava pela luta pela redemocratização do país e era formada por estudantes de direito da PUC/SP, dentre os quais se destacam: Henrique Pacheco, Antônio Mentor, Antônio Sampaio do Amaral Filho, José Mentor, Armando Novaes, Claudio Vergueiro Lobo, José Eduardo Cardoso, Celso Fiorillo Filho, Inês Maria Teixeira, Ernesto Tzirulnik, Fabio Ulhoa Coelho, Alberto Zacarias Toron, José Laurindo de Oliveira, Marcelo Sodré, Renato Galotti, Bruno Blecher, Luiz Felipe França, Mauricio Augusto Gomes e Sergio Magalhães dentre outros. 
Nesse contexto, incorre uma inflexão na atuação dos departamentos jurídicos dos Centros Acadêmicos das principais universidades da época, cuja atuação, até então, pode ser classificada uma marcada pela prestação de serviços de maneira individual e submetida à lógica positivista característica do Direto tradicional ou pela participação em grandes campanhas cívicas em defesa de temas gerais da sociedade ${ }^{18}$. Essa lógica passa a coexistir com uma perspectiva marcada por maior vinculação aos movimentos sociais, por um discurso voltado à concretização de Direitos e pela busca de autonomia funcional suficiente para ampliar a ação universitária para além das funções de crítica e extensão universitários então hegemônicos no mundo do Direito.

Nos idos de 1983, em funções de dissidências internas no movimento estudantil, constitui uma organização própria, pioneira do que posteriormente veio a se denominar assessoria jurídica popular. A criação da Associação de Defesa da Moradia - ADM, que reunia advogados recém formados e estagiários para o trabalho em associações populares ou movimentos de moradia em formação nas periferias passa a integrar o conjunto de atores que se dedicam a disputa pela garantia de direitos nas cidades. O trabalho também é exercido de maneira técnicopolitica, na medida em que alia orientação jurídica, defesa processual e formação política fortemente influenciada pela atuação dos agentes pastorais identificados com a Teologia da Libertação.

A atuação se sustentava a partir de um convênio à época patrocinado pela FABES (Secretaria de Assistência Social do Município) durante a gestão do Prefeito Mario Covas. Naquela oportunidade, a ADM possuía uma relação estreita com a igreja católica que tinha o arcebispo Dom Paulo Evaristo Arns como um grande defensor dos direitos individuais cerceados pelo regime militar e por Dom Luciano Mendes de Almeida, bispo auxiliar responsável pelo acompanhamento de parte significativa da zona leste da cidade, berço de lutas memoráveis por saúde, moradia, transporte, entre outras.

\footnotetext{
${ }^{18}$ O Centro Acadêmico XI de Agosto, da Universidade de São Paulo, foi fundado em 1906 e tem papel relevante nas principais passagens dos conflitos políticos da República como a "Resolução Constitucionalista", a campanha "O petróleo é nosso" e as lutas pela redemocratização do país. Também possui um departamento jurídico dedicado ao atendimento de demandas sociais.
} 


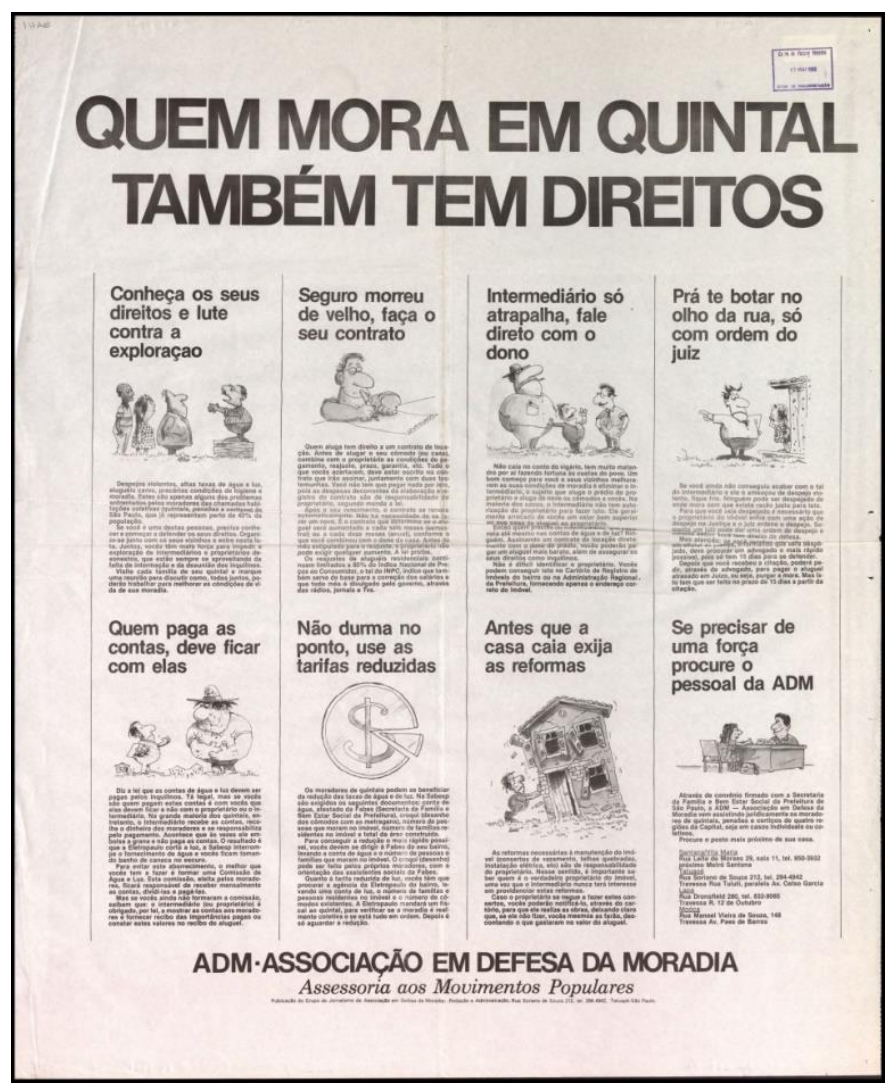

Fonte: Acervo eletrônico do Centro Pastoral Vergueiro.

Não se tratava de uma ação isolada, mas do paulatino espraiamento da ação para os cortiços da região central e para as periferias das regiões Leste, Sudeste e Norte da cidade. $\mathrm{O}$ trabalho era exercido a partir de núcleos regionais. Enquanto, por exemplo, na região norte, articulavam ocupações de terra, com a participação da advogada Marilda Mazzini e Lauro Marcondes, na zona noroeste, articulavam-se, além das ocupações, as lutas pela regularização dos loteamentos, na zona noroeste sob a influência de Henrique Pacheco, na zona leste, a partir de plantões de atendimento na região de São Mateus, via-se a repercussão das lutas operárias do $A B C$, os fundos de greve em apoio ao movimento sindical, o fortalecimento do movimento popular de saúde e a articulação pela criação do Movimento em Defesa do Favelado - MDF, sob orientação do padre missionário Patrick Clarke e sua congregação de padres espiritanos oriundos da Irlanda e do Movimento Sem Terra Leste 1, em 1987, cujo papel será detalhado mais adiante, mas cuja contribuição à viabilização dos mutirões autogestionários é amplamente reconhecida na literatura especializada. 
Entre 1986 a 1988 - Governo Jânio Quadros - havia uma iniciativa de remoção das favelas de áreas públicas, em todos os setores da cidade. Neste momento iniciava-se o empreendimento Santa Etelvina, no extremo da zona leste e as famílias eram deslocadas para lá. Então a atuação foi muito significativa no sentido de garantir a posse da terra com os moradores. A experiência ficou registrada da obra de Dommezi et. al. (1999).

Nesses casos, os advogados combinavam uma ação no nível da mediação dos conflitos por meio da celebração de acordos com proprietários cujos imóveis fossem do interesse do movimento, por meio de defesas judiciais que buscavam ampliar a aplicação de instrumentos jurídicos já presentes na legislação adaptandoos à realidade das lutas populares e ainda realizando processos de capacitação de lideranças em torno de uma plataforma de "novos direitos". Assim, foi se sedimentando a noção de que era necessário utilizar a legislação como um instrumento de transformação social mesmo anteriormente à promulgação da nova constituição. Expressões como "concessão do direito real de uso", "usucapião", dentre outras, passaram a ampliar o repertório das lutas populares.

Desse modo, desde os primórdios, os movimentos de moradia buscaram estabelecer sua organização combinando a chamada ação direta com a capacidade de propositura de alternativas no âmbito da institucionalidade formal.

A assessoria jurídica popular sofreu muitos dos contratempos a que nos referimos em relação aos grupos de assessoria técnica na área de arquitetura.

Mas, para além da intermitência dos programas públicos, o processo mais geral de transformação a que se submeteu a administração pública, no caso do acesso à justiça, levou a criação das Defensorias Publicas da União e a Defensoria Pública do Estado de São Paulo. De um lado, ampliou-se o acesso individual às demandas judiciais, o que tem especial relevância, especialmente no campo penal. Por outro lado, entretanto, rarearam as iniciativas da administração pública para apoiar os projetos dos movimentos populares.

O trabalho de assessoria jurídica gratuita na área da moradia continua sendo praticado, seja por meio de relação autônoma dos profissionais com as entidades, nos departamentos jurídicos do centros acadêmicos, no escritórios modelos vinculados às Universidades ou nas organizações não governamentais remanescentes. 
A institucionalização da produção habitacional autogestionária, como será exposto à frente, a assessoria jurídica torneou-se um componente imprescindível para as associações fazerem frente às exigências dos programas.

\subsection{Os programas municipais}

O contexto de ampla mobilização social que redundou na promulgação da nova constituição também favoreceu a eleição de governos progressistas, dentre os quais o de Luiza Erundina de Souza (1989-1992), em São Paulo.

As novas perspectivas abertas a partir disso foram documentadas em trabalhos como o de Patarra (1992) e SINGER (1996) e, dentre outras importantes inovações políticas conectadas aos preceitos descentralizadoras de inversões de prioridades públicas que então se almejava, significou a inclusão da produção autogestionária de moradia no conjunto de políticas públicas de habitação. Para SINGER (1996, p. 14):

\footnotetext{
"Ela entendeu, e rendo aqui minhas homenagens ao seu gênio político, que as transformações da cultura política que almejássemos somente poderiam ser alcançadas com a participação de todos os antagonistas, das classes trabalhadoras, dos movimentos sociais urbanos e empresariado".
}

O Programa FUNAPS Comunitário executado no governo Erundina decorre de um conjunto de experiências anteriores, eventualmente chamada de experiências alternativas ou programas de autoconstrução assistida, ou simplesmente programas de mutirão, já analisadas em maior profundidade no conjunto de estudos anteriores que permanecem atuais ainda atualmente.

Há razoável consenso na literatura específica e disso não difere RONCONI (1995, p. 63), que atuou como diretor de projetos da Secretaria Municipal de Habitação e Desenvolvimento Urbano da Prefeitura e foi responsável direto pela implementação inicial do programa, que ele foi possível graças ao quadro geral de ampla mobilização social da época, marcada por grandes ocupações de terras para fins habitacionais realizadas por movimentos sociais e com apoio de agentes pastorais e técnicos comprometidos com a agenda da reforma urbana. 
O relato do antigo coordenador do programa indica que o programa partiu da elaboração de um plano de trabalho ${ }^{19}$ estruturado em quatorze grandes linhas que priorizaram o atendimento à população de menor renda com a finalidade de ampliar a oferta para este público, priorizavam a demanda organizada em movimentos de luta por moradia ou de urbanização de favela, incluía o acompanhamento da execução das obras com apoio de trabalho social, visando estimular a participação dos futuros moradores no processo da obra, a conclusão de obras das administrações anteriores que estavam paralisadas, a produção de lotes urbanizados, a regularização fundiária e a urbanização das favelas, a prevenção ou eliminação das áreas de risco, a produção de conjuntos habitacionais de menor porte e distribuídos pelo território da cidade, o apoio técnico para a compra de terrenos por movimentos de moradia, apoio jurídico para a viabilização das ações de usucapião necessárias à segurança jurídica da população favelizada, esboçavam operações de assistência técnica multidisciplinar (arquitetos, advogados, técnicos sociais) para os cortiços, estímulo ao aumento da densidade populacional, conjugadas com os usos institucionais, estímulo as formas alternativas de garantia da posse ou do direito à moradia, o reconhecimento das entidades representativas dos futuros moradores como entidades organizadoras dos empreendimentos e articulação da SEHAB com os demais órgãos da administração.

Em termos concretos, o primeiro projeto foi iniciado com a execução das obras de infraestrutura em menos de 90 dias após o início do governo e o convênio para a construção das unidades e serviços complementares com a Associação ST Leste $1^{20}$ foi assinado em agosto de 1989 para a construção de 82 unidades. Localizado no extremo da zona leste da cidade, no bairro do Jardim Santo André, o empreendimento foi batizado com o nome de "Mutirão São Francisco, Setor V".

\footnotetext{
19 "Programa de Ação Imediata da Secretaria de Habitação".

${ }^{20}$ Conforme o depoimento informal de Rita Aparecida de Ângelos, então coordenadora da entidade, o movimento denominou-se "ST Leste 1" porque o oficial de registro se recusou a aceitar a denominação "Sem Terra", vista por ele como uma denominação perniciosa e ilegal. É obvia exigência abusiva e ilegal, mas representa claramente o clima político vigente à época, de clara e aberta conflituosidade.
} 
Figuras 2 e 3 - Mutirão São Francisco - Setor 5
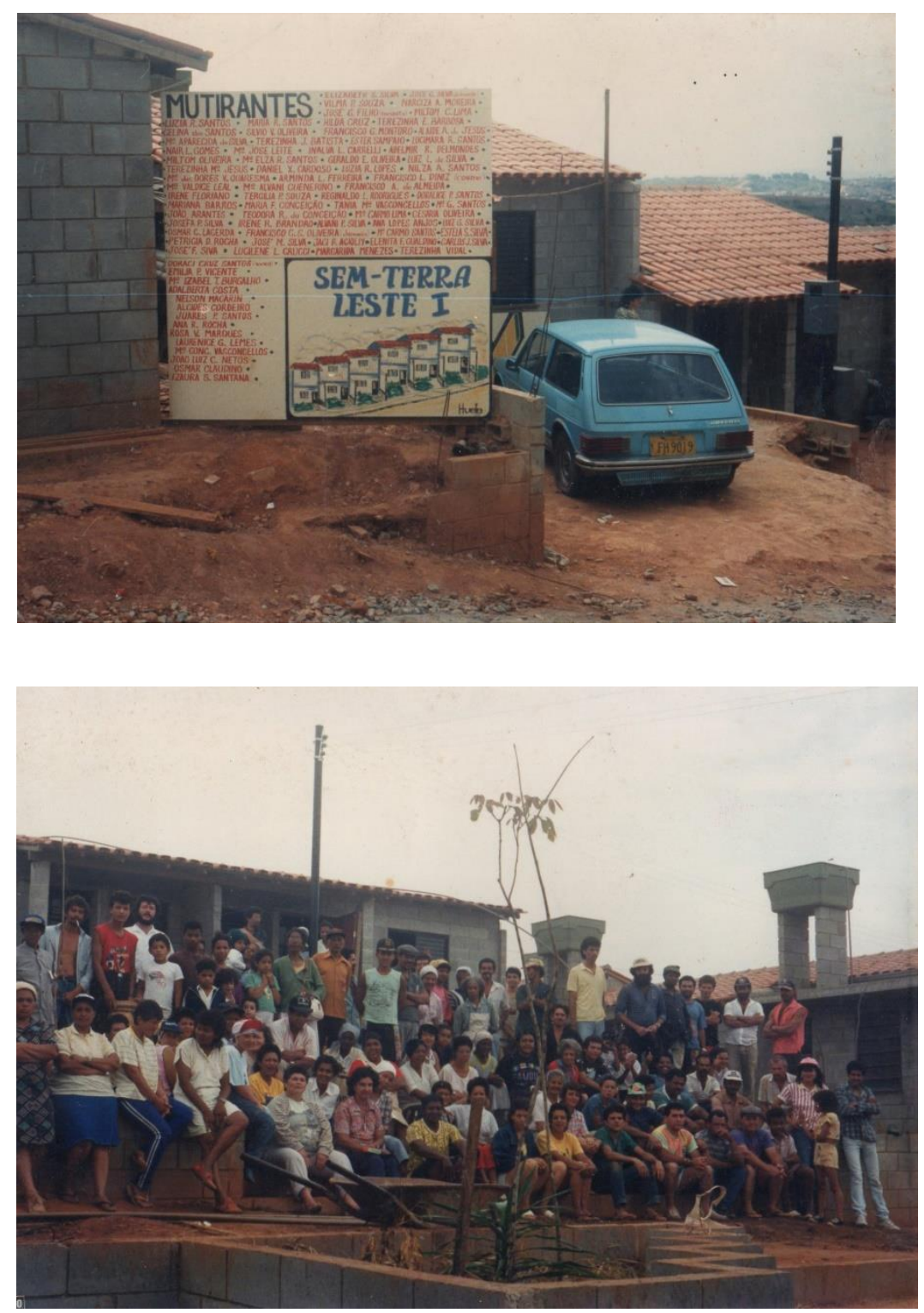

Fonte: Acervo MST Leste 1

Especialmente se comparado com os programas que se sucederam nos anos seguintes nas demais esferas de governo, fica evidente a determinação política em viabilizar rapidamente o programa alternativo naquele momento histórico.

Ainda segundo RONCONI (1995, ob. cit. p.) o programa passou a operar a partir de uma nova estrutura, baseada na reformulação administrativa da SEHAB, na nova interpretação dada ao artigo $7^{\circ}$, inciso II, da Lei do FUNAPS que passou a admitir a contratação com as pessoas jurídicas (associações sem fins lucrativos ou cooperativas) e por uma série de regulamentos internos, então denominados, 
Instruções de Serviços, que puderam estabelecer o conjunto de regras e procedimentos para a atuação cotidiana do programa.

Sobre o marco institucional que emoldurava o programa, é necessário registrar também que ele se estabeleceu a partir da utilização dos recursos orçamentários e extra orçamentários alocados no FUNAPS.

O Fundo de Atendimento à População moradora e Habitação Subnormal FUNAPS foi criado pela Lei Municipal no $8.906 / 79$ se constituiu como um fundo especial de natureza financeira, vinculado ao atendimento de pessoas físicas ou jurídicas de menor renda e moradora em áreas inadequadas, conforme critérios da administração, a partir de recursos orçamentários e extra orçamentários do Município.

Criado no âmbito da Secretaria Municipal de Habitação e Desenvolvimento, aproveitando-se da existência da Lei Municipal no 8.906, de 27 de abril de 1979, foi regulado também por meio do Decreto nำ15.889, de 23 de maio de 1979.

O programa combinava a determinação dos gestores e ao mesmo tempo respondia a uma pressão concreta dos movimentos sociais embrionários do período de distensão do regimento autoritários para o regime democrático Nas palavras da de ROSSETO (2003, p. 28):

\footnotetext{
"era uma forma de responder à pressão da Igreja Católica, das comunidades de base e de organizações populares, incluindo a de favelados, dotando o setor responsável de um instrumento jurídico financeiro com maior capacidade de ação".
}

Ao longo dos anos, na rica trajetória contada pelos autores citados nesse capítulo, passou do atendimento habitacional de caráter assistencialista, pontual e esparso, ao principal mecanismo de sustentação financeira do programa de mutirão autogerido.

O FUNAPS implicou numa mudança radical da forma de enfretamento do problema habitacional na medida em que buscava substituir remoção forçada realizada com o abuso da repressão policial pela tentativa do atendimento individual por meio de ações emergenciais. Ainda segundo a Autora (2003, ob. cit. p. 30):

"É importante ressaltar como a lei que criou o Funaps permitiu que o Município começasse uma atuação autônoma em relação ao governo federal por meio da viabilização de novas diretrizes para a moradia". 
"A lei que havia instituído o Funaps era muito clara em relação a dois aspectos fundamentais: a demanda a ser atendida era constituída pela população residente no Município que ganhava até 4 salários mínimos regionais e morava em habitação considerada subnormal e os recursos poderiam ser aplicados a Fundo perdido".

Ao constituir um fundo de habitação, criou-se uma conta específica para a qual fluiriam determinados recursos com a finalidade de ampliar a possibilidade de intervenção para fins habitacionais. Ou seja, tendo em vista que as políticas habitacionais se desdobram para além do exercício orçamentário anual, o que se buscou foi a garantia de uma fonte permanente de recursos, formada por recursos orçamentários e extra orçamentários, onerosos e não onerosos num "mix" capaz de suportar o desenvolvimento da obra até a sua conclusão definitiva sem eventuais interrupções próprias dos ajustes orçamentários vinculados à arrecadação anual da administração.

A constituição de um fundo financeiro permitiu também a adoção de uma política de subsídios adaptável à realidade socioeconômica dos futuros beneficiários por meio da combinação da concessão de financiamentos com diferentes níveis de retorno ou mesmo a fundo perdido de modo a permitir a adoção de ações de políticas públicas redistributivas visando a obtenção da igualdade material no atendimento aos cidadãos.

Em termos concretos, ainda conforme Rossetto (2013, p.18), com a criação do FUNAPS foi possível priorizar a demanda de menor renda moradora de áreas insalubres, permitir à administração municipal constituir uma alternativa habitacional para aqueles que não podiam acessar os recursos do Sistema Financeiro da Habitação, habilitando-se, inclusive como um novo agente financeiro com capacidade de captação de recursos de outras fontes. Ou seja, busca-se garantir o atendimento da população de menor renda a fundo perdido ou em financiamentos subsidiados e o atendimento da população com melhores condições de renda nos programas públicos desenvolvidos com recursos onerosos e conforme as regras do Sistema Financeiro da Habitação.

Inicialmente, conforme a previsão legal, o FUNAPS estava vinculado à Secretaria de Administrações Regionais e, especialmente, às coordenadorias de bem estar social desses órgãos, razão pela, ainda conforme RONCONI (1995, p. 268) de início suas intervenções tinham caráter pontual e foram alocados para a realização de pequenas intervenções esparsas no território tais como a compra de 
barracos, passagens para mudanças para o estado de origem, melhorias habitacionais, dentre outras ações de natureza emergencial.

A chamada lei do FUNAPS também buscou instituir, por meio de um conselho deliberativo, um esboço de sistema de controle social com atribuições de planejamento, flexibilidade de regulamentação que poderia ser encaminhada com o uso de Resoluções, Instruções de Serviços ${ }^{21}$, de interlocução com a Câmara Municipal e de fiscalização da utilização dos recursos.

O programa, de forma inovadora, estabeleceu um valor máximo por família e por m2 da unidade habitacional, fixou um tamanho mínimo para as unidades (60m2) e destinou recursos para o pagamento de assessoria técnica (contratada pelas associações), para a compra de ferramentas, para a locação de equipamentos, organização do canteiro de obras e pagamento da mão de obra especializada;

Como já se disse o programa contou com grande engajamento dos atores políticos e dos atores com atuação na sociedade civil, ainda que, como é salutar ao processo democrático, não estivesse infenso à eventuais críticas. Para CONSTANTINO (2007, p. 141) o programa de mutirões:

\begin{abstract}
"Mas, apesar de uma ampla maioria muito favorável, evidentemente, não há uma unanimidade em relação ao programa, mesmo dentro dos setores mencionados. (...) O grande estusiamos pelo programa é justificado, geralmente, pelas vantagens que teria de permitir uma redução dos custos de produção, de apresentar projetos e construções de melhor qualidade, de possibilitar a participação do futuros moradores na elaboração do projeto e na gestão da obra... (...) Já as críticas que esse programa recebe concentram-se em torno do sobre-trabalho; de que teria baixa produtividade; da prevalência dos critérios definidos pelas associações, no processo de seleção da demanda, em detrimento de critérios "universais"; de dificuldades do poder público para conter eventuais "desmandos" de lideranças e injustiças em relação a mutirantes..."
\end{abstract}

Nos movimentos de moradias reconhecidos por sua atuação naquele momento histórico, guardadas as devidas nuances, também prevalece relativo

\footnotetext{
${ }^{21}$ De acordo com o Manual de Redação da Presidência da República, instituído na Lei Federal no a lei é um ato normativo primário e contém, em regra, normas gerais e abstratas, postas em regra por meio de processo legislativo (projeto de lei, discussão e aprovação legislativa e sanção do titular do poder executivo). Por outro lado, a regulamentação da lei, quando necessária, ocorre por meio da edição de decretos são atos administrativos da competência exclusiva do chefe do executivo, ou delegados aos demais gestores, destinados a prover situações gerais ou individuais, abstratamente previstas. O regulamento é veiculado por meio de Decretos, Resoluções, Portarias ou Instruções de Serviço. No caso especifico do FUNAPS, conforme Amaral (2002, p. 141), as Instruções de Serviços expedidas no programa eram submetidas ao Conselho do FUNAPS e se destinavam à definir os os parâmetros urbanísticos dos projetos, os critérios de avaliação dos orçamentos, as formas de prestação de contas, dentre outros.
} 
consenso no sentido de que o programa atendeu às demandas formuladas: Para PESSINA (2005), arquiteto da Assessoria Técnica CAAP reconhecido por sua atuação desde os primórdios do cooperativismo habitacional uruguaio e pioneiro também na experiência brasileira, com firme atuação na vida orgânica das organizações da época:

"Essa política pública foi possível porque existiram uma vontade
política clara, um movimento forte e organizado que tinha propostas
e experiência nesse campo, e um grupo de técnicos que
assessoravam esse movimento e que foi chamado a ocupar a
Superintendência de Habitação Popular (Habi) da Secretaria
Municipal de Habitação e Desenvolvimento Urbano".

Cabe ainda registrar que posteriormente à promulgação da Constituição Federal, coube aos entes estaduais elaborarem suas constituições estaduais e aos entes municipais elaborar sua própria Lei Orgânica ${ }^{22}$.

A Lei Orgânica do Munício de São Paulo possui a particularidade de destacar - grau de comprometimento com a gestão de políticas públicas com ampla participação da sociedade e, inclusive, com o reconhecimento da relevância dos movimentos sociais. Diz logo de início no capítulo destinado à regular sua organização administrativa:

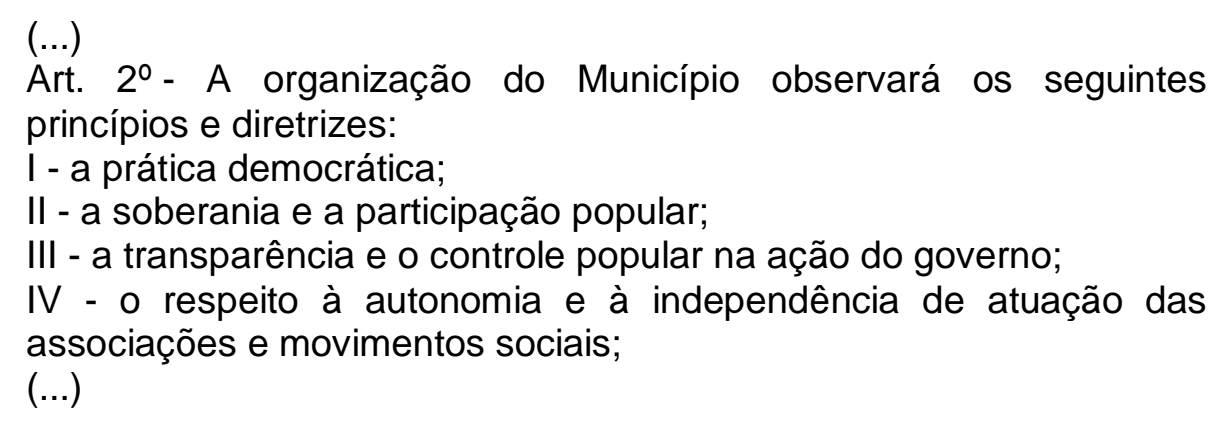

Evidentemente que não é possível aferir uma relação direta entre o texto idealizado presente na norma jurídica e a sua aplicação eficaz nas políticas públicas concretas. Mas, por outro lado, não se poderá acusar de juridicamente ilegítima a busca de constituir novas normas e programas compatíveis com a previsão dos Estatutos programáticos.

\footnotetext{
${ }^{22}$ A Lei Orgânica é um instrumento jurídico previsto no art. 29 da Constituição Federal e constitui instrumento normativo primário destinado a regular, de modo subordinante - e com inegável primazia sobre o ordenamento positivo municipal - a sua vida jurídico administrativa e político-institucional. É o ato fundante da ordem jurídica local. É informalmente tratada como uma espécie de constituição do âmbito local.
} 
A Lei que criou o FUNAPS possuía onze artigos destinados à: criar o fundo, determinar o atendimento do público de baixa renda, constituído por famílias com até 04 (quatro salários mínimos regionais), em condição de precariedade habitacional, constituía as receitas integrantes do fundo (ações da Prefeitura Municipal, dotações orçamentárias próprias ou que lhe fossem destinadas, reaplicação de seus próprios recursos, dentre outras fontes ${ }^{23}$ ), a destinação das rubricas (aquisição de lotes, compra de material, aquisição da casa própria, melhorias habitacionais, dentre outras ações equivalentes), a criação de um conselho deliberativo, composto por integrantes da administração e da população beneficiária, inclusive representantes das associações representativas, órgão com competência deliberativa, autorizava a utilização dos recursos para obras de infraestrutura, celebrar contratos de financiamento com pessoas físicas ou jurídicas, e dá dava outras providências administrativas.

O Decreto Municipal no 15.889/79, com alterações posteriores, regulamentou a Lei de referência para estabelecer o detalhamento da operacionalização dos programas dele derivados, abarcando aspectos como forma de concessão do financiamento, órgãos e departamentos responsáveis pelo processamento dos projetos, meios de atendimento direto à população, formas de garantia dos recursos tomados, prevalecendo a garantia hipotecária ${ }^{24}$, competência da SEHAB para avaliação do imóvel objeto do financiamento e representar a administração nos contratos pertinentes, regulamentaram o funcionamento do Conselho Deliberativo, dentre outras alterações de natureza administrativa. As alterações que transferiram as competências da Secretaria de Bem Estar Social para a SEHAB foram instituídas pelo Decreto Municipal n 32.923, de 29 de Dezembro de 1992.

De ampla relevância para o funcionamento do programa, foram as chamadas ordens de serviço. A primeira ordem de serviço expedida regulava os seguintes aspectos do programa: Definição dos agentes envolvidos, parâmetros para atuação da associação, com forte valorização de sua autonomia, papel da assessoria técnica, acolhendo o pleito de liberdade de escolha dos técnicos identificados com trajetória daquele grupo, dentre outras diretrizes para obtenção do financiamento, titularidade do terreno, prazos e limites do financiamento.

\footnotetext{
${ }^{23} \mathrm{Na}$ época integravam ainda o Fundo, parcelas dos recursos provenientes da Loteria Estadual

${ }^{24}$ Entende-se por garantia hipotecária um tipo de direito real em que um bem do devedor assegura ao credor o pagamento de uma dívida. O instituto está regulado no artigo 1225, inciso IX do Código Civil Brasileiro.
} 
A Instrução de Serviço oo 07 estabeleceu normas para uniformizar os procedimentos de financiamento habitacional direto às associações comunitárias para a construção de moradias por mutirão, relacionou os documentos técnicos necessários à análise da viabilidade, a forma jurídica da contratação (convênio), o regime de execução e a possibilidade de contratar serviços especializados. Também estabeleceu a forma de aprovação, fiscalização e supervisão dos convênios (análise da demanda).

As demais instruções de Serviço, conforme a compilação de RONCONI (1995, p. 63-74), buscam regulavam aspectos do relacionamento entre a administração e as conveniadas e diretrizes da própria organização das entidades que visavam estabelecer princípios e parâmetros cujo debate se faz presente ainda nos dias atuais.

Basicamente, estabeleceram a administração compartilhada assentada no trinômio: administração, associações comunitárias e assessoria técnica de arquitetura. Ao governo competia disponibilizar imóveis (seja pela cessão de imóveis públicos ou em desapropriação), pela disponibilização de recursos financeiros (garantidos num fundo público e gerido democraticamente) e também exercício do dever de fiscalizar e regular o programa, As associações comunitárias, por sua vez, competia constituir e organizar o grupo de associados e coordenar o processo de elaboração dos projetos, de execução da obra e do trabalho social e, finalmente, as assessorias técnicas especializadas, formadas por profissionais de arquitetura com atuação no ramo habitacional, a quem competia aportar o conhecimento técnico suficiente para a aferição do atendimento à condições tecnológicas dos projetos.

O marco regulatório inicial do programa de mutirões se dedicou a regulamentar a definição dos agentes, da assessoria técnica, do modelo de financiamento, das características dos imóveis, e implicou em constantes alterações tanto na estrutura administrativa como no funcionamento das organizações.

O Decreto Municipal no 29.213/90 permitiu a integração dos recursos do FUNAPS ao sistema de execução orçamentária da Prefeitura, aperfeiçoando o controle de gastos e permitindo maior transparência no acesso às informações sobre sua utilização.

Posteriormente, com a edição do Decreto Municipal no 15.889/79 com a redação que the foi dada pelo Decreto Municipal o 32.923/92, também foras estabelecidos procedimentos necessários à atuação da Secretaria Municipal de 
Habitação e Desenvolvimento Urbano, especialmente para a formalização dos contratos, adoção de um sistema de garantia hipotecária, avaliação financeiras das moradias produzidas e registro imobiliário dos empreendimentos.

Portanto, no nascimento do programa autogestionário de habitação, a principal alteração não dependeu da formulação de uma nova lei, mas, a partir de uma nova orientação política, da operacionalização do redirecionamento dos recursos financeiros, até então majoritariamente destinados às ações pontuais, para sua integração no esforço de constituição de uma política habitacional com princípios comunitários.

De acordo com Amaral (2002, p. 27) a administração da época eliminou as divisões regionais de atendimento, transferiu funcionários experientes, desmontou equipes técnicas e mecanismos de controle, paralisou projetos em andamento, interrompeu programas de reforma dos cortiços, de fornecimento de assessoria técnica e suprimiu a maioria dos canais de construção democrática da política.

No caso do programa de mutirões autogerido, os convênios do programa foram submetidos a uma auditoria promovida pelo Tribunal de Contas do Município. CARVALHO (2004, p. 35) registra que o procedimento tinha por justificativa a investigação sobre a eventual prática de crime de loteamento ${ }^{25}$ e nas relações contratuais das associações com assessorias jurídica e social para o desenvolvimento dos projetos. O Procedimento encontrou irregularidades pontuais, que em nada desnaturavam o programa e que envolviam um único convênio (de um conjunto habitacional de um total de 93) e não resultou em nenhum procedimento criminal ou condenação judicial. Entretanto, serviu como justificativa política da administração de turno, para determinar a paralisação do programa.

Com a finalização das auditorias e diante de forte pressão dos movimentos de moradia, o governo do Prefeito Celso Pitta retomou a contratação de novos projetos. No entanto, embora a contratação tenha significado a destinação de terrenos e o início da execução dos contratos, com a liberação da parcela de recursos relativa a instalação dos canteiros, ao menos em alguns dos contratos, nenhuma das obras contratadas foi iniciada.

\footnotetext{
${ }^{25} \mathrm{O}$ parcelamento do solo urbano sem prévio registro (que implica em prévio licenciamento urbanísticoambiental) constitui crime contra a administração pública, conforme a previsão do art. 50 da Lei Federal 6.766, de 19 de Dezembro de 1979, conhecida como Lei dos loteamentos.
} 
Posteriormente, ainda nessa gestão, o FUNAPS foi extinto e suas atribuições foram transferidas para o Fundo Municipal de Habitação que até hoje suporta as ações da política habitacional que se relaciona com a proposta autogestionária, como se verá adiante.

No entanto, em breve síntese, o programa FUNAPS - Comunitário financiou e desenvolveu a primeira a iniciativa de fôlego de produção autogestionária no Brasil. O tripé formado pela atuação conjunta entre o Poder Público, as associações dos futuros moradores e as organizações de assessoria técnica permanece no imaginário dos atores envolvidos e na experiência concreta como a fórmula básica para a viabilização de qualquer programa dedicado a essa nova forma de produção habitacional.

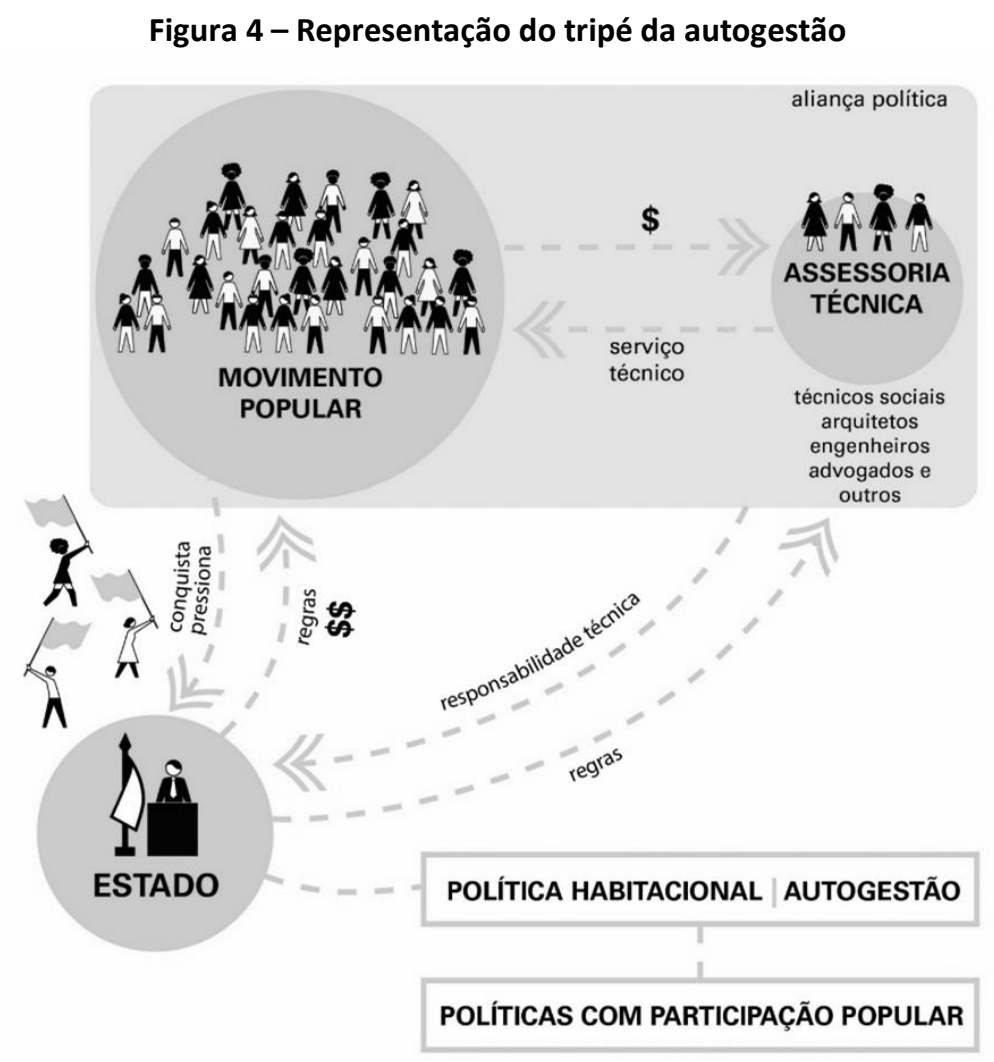

Fonte: UNMP, 2009

Do ponto de vista dos desafios jurídicos, BONDUKI (1992, p. 141) seleciona, dentre os temas polêmicos dos processos autogestionários: (i) a forma da propriedade da terra e das unidades habitacionais; (ii) as opções arquitetônicas e urbanísticas das unidades habitacionais; (iii) o processo de produção; AMARAL (2002, ob. cit. 136) aposta questões relativas ao (i) grau de autonomia das 
associações; (ii) maior profissionalização das lideranças; (iii) o desenvolvimento de atividades de geração de renda, como cozinhas e padarias comunitárias ou de garantia de direitos como projetos de assistência social, dentre outras possibilidades. Os questionamentos decorrentes das auditorias mencionadas por RONCONI (1995, ob. cit.) e CARVALHO (2004, ob. cit.) prenunciam a complexização das questões relacionadas aos procedimentos de prestação de contas e à regularidade dos procedimentos de licenciamento urbanístico, dentre outros aspectos.

Ao mesmo tempo em que o sucesso do programa incentiva a formulação de novos regramentos, como se deu no caso da propositura do primeiro projeto de lei de iniciativa popular nos marcos do processo participativo proposto na nova CF, também as dificuldades levaram os autores a refletir sobre a necessidade de ampliar o regramento dos programais habitacionais autogestionários.

\subsubsection{O Programa de Produção de Moradias em regime de mutirão autogerido}

Mesmo após o período do FUNAPS - Comunitário, com a superveniência do Fundo Municipal de Habitação, as propostas de produção autogestionária continuaram sua trajetória, desta vez reguladas na Lei Municipal no 11.632, de 22 de julho de 1994, regulamentadas por Resoluções expedidas inicialmente pelo Conselho Gestor do Fundo Municipal de Habitação e, posteriormente, pelo Conselho Municipal de Habitação. E os projetos, ainda que em posição de menor relevância nas estratégias públicas, permaneceram sendo desenvolvidos ${ }^{26}$.

Entre o final de governo de Luiza Erundina (1992) no âmbito municipal e o início do primeiro governo Lula âmbito federal (2002), alternaram-se na gestão da cidade de São Paulo, governos conservadores (Paulo Maluf, 1993-1996; Celso Pitta, 1997-2000 e José Serra/Gilberto Kassab, 2005-2012) e progressistas (Marta Suplicy, 2001-2004 e Fernando Haddad, 2013-2016).

O período é caracterizado, ainda que ressalvas a diferença de postura nos governos petistas, nos estudos nos quais essa pesquisa se baseia como portador de

\footnotetext{
${ }^{26}$ O Programa de Mutirões ainda continua formalmente vigente até os dias atuais, desenvolvidos, atualmente no âmbito da Diretoria Técnica da COHAB/SP. No entanto, rarearam definitivamente as novas contratações e basicamente, restaram apenas alguns contratos cuja execução encontra-se paralisada momentaneamente ou em andamento.
} 
um retrocesso significativo da política urbana e habitacional de forma geral e, isso se aplica integralmente em relação ao programa de mutirão autogerido.

No entanto, no campo normativo, a proposta autogestionária continuou presente, inclusive em razão das fortes mobilizações sociais do período. A Lei Municipal n 11.632, de 22 de julho de 1994, visava pretensamente criar uma política municipal de habitação para a população de baixa renda e sua aplicação variou, conforme a orientação política preponderante em cada administração que se seguiu. No governo de Paulo Maluf, de fato, significou a paralisação dos projetos autogestionários e o redirecionamento das prioridades. O projeto mais relevante do período se chamava "Projeto Cingapura" que, conforme a própria administração era uma iniciativa da Secretaria Municipal de Habitação e Desenvolvimento Urbano que visava a urbanização definitiva de favelas e de áreas degradadas, com a construção de prédios de apartamentos, urbanização dos lotes a serem preservados e relocação das habitações e lotes remanescentes para atendimento das diretrizes do projeto global de cada área com eliminação das áreas de risco, transformando as favelas em verdadeiros bairros e cujos recursos estavam diretamente ligados ao gabinete do Secretario de Habitação.

Por outro lado, inicialmente a Lei constituiu o Conselho Municipal do FMH, disciplinado nos artigos 12 e 13 passou um longo período de embates entre a administração e os movimentos de moradia que vigorou entre 1994 e 2002, tendo inclusive expedido cerca de uma dezena de resoluções com a regulamentação de ações habitacionais relevantes. No entanto, a nova lei, construída sem o amplo debate que marcava até então a discussão de política habitacional, embora vigente, possui pouca efetividade, dado que há tempos, na cidade, a política de habitação, estava fortemente concentrada na implantação de um programa controverso chamado "Projeto Cingapura", supostamente voltado à urbanização de favelas.

A Lei da política habitacional se inicia prometendo que a SEHAB elaboraria uma política de habitação com princípios, objetivos e diretrizes compatíveis com a noção de direito à moradia:(i), facilitar e promover o acesso a habitação, com prioridade para a população de baixa renda; (ii) articular, compatibilizar e apoiar a atuação dos órgãos e entidades que desempenhem funções no campo da habitação de interesse social; (iii) priorizar programas e projetos habitacionais que contemplem a melhoria da qualidade de vida da população de menor renda e contribuam para a geração de empregos; (iv) democratizar e tornar transparentes os procedimentos e 
processos decisórios; (v) desconcentrar poderes e descentralizar operações; (vi) economizar meios e racionalizar recursos visando a auto-sustentação econômicofinanceira; (vii) fixar regras estáveis simples e concisas; (viii) adotar mecanismos adequados de acompanhamento e controle do desempenho dos programas habitacionais; (ix) empregar formas alternativas de produção e de acesso à moradia, através do incentivo à pesquisa e ao desenvolvimento tecnológico, objetivando novas técnicas de produção, construção, comercialização e distribuição de habitações; (x) integrar os projetos habitacionais com os investimentos em saneamento e os demais serviços urbanos; (xi) viabilizar estoque de terras urbanas, necessária a implementação de programas habitacionais.

A Lei buscou ainda equalizar o papel da SEHAB, conferindo-lhe a qualidade de órgão central e a quem competiria orientar a ação dos demais entes públicos nas diferentes instâncias e da iniciativa privada e o papel da Companhia Metropolitana de Habitação - COHAB/SP a quem foi atribuído o papel de órgão operador da política, a quem competiria implementar a Política Municipal de Habitação em consonância com as metas e prioridades estabelecidas pela SEHAB e aprovadas pelo Conselho Municipal de Habitação, além de responsabilizar-se pelo processo de execução dos programas, inclusive os de produção das unidades.

Finalmente, a Lei ainda criou o Fundo Municipal de Habitação - em substituição ao antigo FUNAPS - e o Conselho Municipal Gestor do Fundo. O novo fundo nasceu vinculado diretamente à COHAB, composto por recursos orçamentários próprios ou advindos de outros entes, o retorno de suas aplicações, multas, juros e correção monetária oriundos de suas aplicações, os provenientes de empréstimos, dentre outras fontes.

Após a aprovação da Lei, foi aprovado a Resolução CFMH no 04, de 17 de setembro de 1997 que aprovou um conjunto de 04 programais, quais sejam: (i) Programa Municipal de Moradia de Interesse Social; (ii), Programa de Programa Municipal de Urbanização de Áreas Ocupadas; (iii),Programa de Recuperação de Conjuntos Habitacionais e de Edificações Deterioradas; e (iv), Programa Municipal de Reassentamento Habitacional e Programa Municipal de Regularização de Loteamentos Irregulares, a partir dos quais decorriam linhas especificas, cada uma delas voltadas para o enfrentamento de determinada demanda habitacional.

O Programa FUNAPS Comunitário foi "rebaixado" à condição de subprograma dentre ao lado de outras três outras possibilidades dentro do programa destinado à 
produção habitacional. Dado o contexto da época, vê-se, claramente que o objetivo era produzir um "apagamento" do volume de produção e do significado do programa da gestão anterior.

A Resolução CFMH oo 04/1997regra aprovada introduziu a obrigatoriedade de prévia regularização do terreno e do parcelamento do solo e a possibilidade de cadastramento de entidades para o desenvolvimento de novos projetos em parceria com a administração. Os projetos em mutirão deveriam

No entanto, o governo Celso Pitta ficou marcado por escândalos de corrupção que mantiveram o governo permanentemente sob fortes criticas de diversos setores da sociedade e, inclusive dos movimentos de moradia. $O$ processo de negociação visando a retomada dos programas não avançou e apenas no último ano foram assinados alguns convênios para novos empreendimentos ${ }^{27}$, que, no entanto, somente foram iniciados no governo de Marta Suplicy.

Enquanto no FUNAPS não dispunha de personalidade jurídica e por estar ligado à administração direta, no FMH, por sua vez, conforme ROSSETTO (2003, p. 60) ao ligar o FMH à COHAB-SP, buscava-se garantir maior agilidade às comercializações das unidades, com benefício aos usuários è administração que poderiam obter a regularidade contratual e a titulação jurídica, fazendo supor uma preocupação com a segurança jurídica das relações. Além disso, a instituição de uma personalidade jurídica também teria a vantagem de acelerar a contratação de serviços, dado que por sua natureza jurídica, a COHAB-SP poderia realizar contratações em procedimentos mais simplificados em relação à administração direta.

No entanto, a eleição de Marta Suplicy, a segunda mulher a dirigir a cidade, (2001-2004) também à época filiada ao Partido dos Trabalhadores, deu-se no contexto politicamente diverso do anterior.

Em síntese, as inovações democráticas prometidas na Constituição Federal não encontravam um solo fértil para seu desenvolvimento. A ideia de inovação da administração pública como sinônimo de ampliação de direitos encontrava limites na formulação de que a administração pública deveria se subordinar a uma lógica de eficiência calcada na redução da atuação do Estado.

\footnotetext{
${ }^{27}$ É o caso dos mutirões Unidos Venceremos, Paulo Freite e Che Guevara, todos do MST Leste 1.
} 
Tampouco era possível encontrar na capacidade de incidência dos movimentos populares como visto na década anterior. CAVALCANTI (2006, p. 135), ao analisar a relação da UMM/SP com a administração de Marta Suplicy, conclui que:

\begin{abstract}
"existem mudanças nos papéis desempenhados por organizações populares junto às administrações governamentais do campo de esquerda no país. Tais mudanças, têm-se mostrado problemáticas, em virtude do uso, por parte da referida gestão, de mecanismos e instrumentos que visavam antes de qualquer coisa o controle político das entidades civis: uma típica ação autoritária, portanto".
\end{abstract}

O PT já não ostentava o mesmo vigor político de outrora, seja em razão da memória das administrações que já haviam exercido, seja em razão da chamada burocratização, e tudo isso acabou por limitar a participação da proposta autogestionária no programa e na formulação de políticas públicas da época.

Do pondo de vista do financiamento, em razão da precariedade das contas municipais, afetadas pelo comprometimento havido pela construção de grandes obras viárias na gestão de Paulo Maluf e pela renegociação das dívidas municipais realizadas por seu sucessor, pois, conforme afirmam BONDUKY e ROSSETTO (2017, p.184) cerca de $13 \%$ da arrecadação do município estavam comprometidos com o pagamento do refinanciamento da dívida municipal. Nesse contexto, avaliavase como prioritária a obtenção de recursos extra orçamentários (CONSTANTINO, 2005, p. 96) de modo em que se pretendia acrescentar aos recursos próprios outros oriundos de fontes como os financiamentos obtidos junto ao (BID) Banco Interamericano de Desenvolvimento, e do BIRD (Banco Mundial), além de parcerias com os demais entes governamentais. Ainda assim, manteve-se uma proposta de programa de mutirões, ainda que numa escala inferior aquela verificada na gestão Erundina. Segundo CONSTANTINO (ob. cit., p.149) que é analista e agente do processo pois exerceu a função de diretor técnico da COHAB/SP no período e recebeu as atribuições que outrora estiveram em $\mathrm{HABI}$, em relação aos mutirões, o período é marcado por novos questionamentos políticos e jurídicos, especialmente aqueles relativos à ausência de controles efetivos tanto da formação do grupo associativo, como dos mecanismos de controle interno das associações e a questão da ausência de licitação para a contratação dos materiais e serviços necessários à execução da obra. 
Contudo, retomou-se o programa noutras bases legais, definidas por Resolução do Conselho Municipal de Habitação. Nesse período, a inovação de maior relevância foi a adoção de um procedimento de chamamento público para a escolha das entidades com regras de credenciamento e hierarquização definidas em edital público. Para CONSTANTINO (ob. cit., p. 153):

\begin{abstract}
"Esse processo de credenciamento e seleção de sociedades civis foi uma das mais importantes mudanças introduzidas no programa, durante a gestão 2001-2004. Com ele, buscava-se garantir a isonomia e a transparência no processo de definição das associações que seriam atendidas no Programa de Mutirões com Autogestão. E, juntamente com uma nova visão das normas do Programa (a ser abordada adiante), buscava melhorar o arcabouço legal de forma a contribuir para sua continuidade, independentemente da simpatia que por ele tivessem as futuras administrações municipais".
\end{abstract}

O procedimento de chamamento público visava atender ao reclamo por aplicação de critérios concorrenciais aos processos de seleção de entidades aptas a desenvolver projetos em parceria com a administração. O tema da obrigatoriedade ou não da realização de processos licitatórios nas relações com as entidades privadas é recorrente e será objeto de maior detalhamento no Cap. IV dessa dissertação.

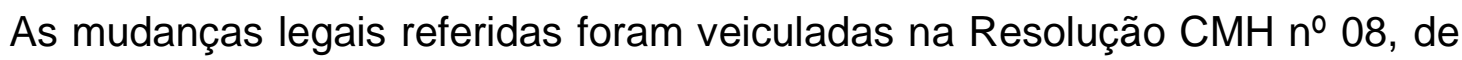
24 de março de $2004^{28}$, último ano de governo.

Do ponto de vista da legitimidade, supera-se a formulação unilateral da administração pública, ampliava-se a participação dos agentes envolvidos por meio da discussão bilateral, no entanto, do ponto de vista da segurança jurídica, não se pode avançar na constituição de leis capazes de projetar o programa a um novo patamar em termos de políticas públicas.

O FMH passou por alterações pontuais: A Lei $\mathrm{n}^{0}$ 13.509/03 permitiu a possibilidade de aquisição antecipada de imóveis para a viabilização de programas habitacionais, a possibilidade de produção de moradias destinadas à locação social ou arrendamento residência com opção de compra, a possibilidade de compra e a

\footnotetext{
${ }^{28}$ A Secretaria Municipal de Habitação, por meio da Secretaria Executiva do Conselho Municipal de Habitação, mantém um sítio eletrônico com o conteúdo das Leis, Decretos, Resoluções, Instruções Normativas, atas de reunião e demais documentos expedidos pelo Conselho, disponíveis para acesso endereço: https://www.prefeitura.sp.gov.br/cidade/secretarias/habitacao/participacao social/conselhos e orgao s colegiados/cmh/index.php? $\mathrm{p}=180547$.
} 
autorização para firmar convênios e parcerias com entidades públicas ou privadas, inclusive instituições financeiras, com o aporte de recursos, mesmo sob a forma de bens imóveis, inclusive com a possibilidade de doação para subsidiar programas habitacionais por elas desenvolvidos; A Lei ํo 13.741/04 introduziu a autorização para que os recursos do fundo pudessem ser usados para prover garantia em transações de locação social; Ou seja, ao longo dos anos, o processo político garantiu algumas alterações pontuais na lei, buscando ampliar o leque de possibilidades de atuação.

Após uma série de embates em torno do tema, somente com a aprovação da Lei municipal ำ 13.425/2002, de autoria do Vereador Adriano Diogo, houve alteração de seu caráter, ampliando suas atribuições. O Conselho Municipal do FMH, passou a ser nomeado Conselho Municipal de Habitação, numa tentativa de ampliar sua atuação para o conjunto das políticas desenvolvidas na área, explicitando-se o seu caráter deliberativo e ampliando a participação da sociedade civil na sua composição. Ainda assim sua efetividade foi relativa, tendo em vista que mesmo nos governos posteriores, inclusive nos de matiz ideológica à esquerda do espectro político, a habitação social deixou de ser uma prioridade explícita. Numa visão panorâmica sobre o período, na síntese de CYMBALISTA e MOREIRA (2002, p. 39):

\begin{abstract}
A implantação desse projeto de lei, no entanto, não correspondeu às exigências de descentralização e transparência dos procedimentos e processos decisórios municipais, tal como visualizado pelos movimentos populares e outros atores da sociedade civil. A representatividade dos movimentos populares ficou restrita e as decisões muito circunstanciais, visto que elas estavam relacionadas diretamente aos programas de mutirão e não a todos os desenvolvidos pela Secretaria de Habitação, cujo principal foco era o Cingapura.
\end{abstract}

Para os projetos de mutirão com autogestão, não houve avanços significativos na estrutura administrativa e no tratamento legislativo.

Ou seja, ainda que o marco legal tenha se mantido vigente, há consenso relativo de que não houveram avanços concretos no plano das políticas públicas habitacionais no âmbito do município nesse período.

Os governos de José Serra e Gilberto Kassab tampouco incentivaram programas autogestionários. No período, o foco da política esteve mais voltado à 
definição de parâmetros para a comercialização das unidades produzidas do que para a viabilização de novos empreendimentos autogestionários.

A Resolução oㅡ 22, de 28 de setembro de 2006 aprova diretrizes para a realização de ações conjuntas entre o Município e Associações Comunitárias, em regime de mutirão associativo, em operações vinculadas ao FMH.

A regra determina que os parâmetros de cada uma das ações a partir de novas decisões do presidente do $\mathrm{CMH}$ (ou seja, o Secretário de Habitação) e que os procedimentos operacionais serão fixadas pela COHAB-SP. Além disso, foram detalhadas diretrizes e definições para as futuras parcerias. Foram definidos: (i) um conceito de mutirão como forma de produção habitacional; (ii) a natureza da mão de obra mutirante, que seria prestada gratuitamente pelos futuros moradores; (iii) o papel da SEHAB como agente gestor e da COHAB como agente operadora do programa e das associações como agentes promotoras; (iv) as modalidades construtivas que poderiam ser a produção habitacional, incluindo a aquisição de terreno, infraestrutura básica pública ou condominial, unidade habitacional, equipamentos comunitários, bem como para a elaboração do Plano de Trabalho Social e sua implantação; (v) e inovava ao admitir uma modalidade de execução de obras de urbanização em assentamentos irregulares ou precários ou mesmo a execução de melhorias habitacionais; (vi) o cadastramento e mapeamento de famílias ocupantes de assentamentos objeto de regularização fundiária; (vii) a regularização dos mutirões existentes; (viii) a realização de trabalho social pré e pós comercialização; (ix) a avaliação de resultados, dentre outras.

A Resolução do Conselho Municipal de Habitação no 36 de 17 de junho de 2008 diante do quadro de inexecução dos programas anteriores, reconhece a existência de "solicitações" dos movimentos de moradia em defesa de um programa de mutirões, reconhece a produção autogestionária é historicamente relevante e favorece a integração e a organização social das comunidades, mas como método para a continuidade dos programas propõe a constituição de um grupo de trabalho dedicado a reformular o programa de mutirões e instituir novas rotinas e procedimentos operacionais.

No final da gestão, quando no plano nacional havia um forte debate sobre a construção de um sistema nacional de habitacional, com o pleno funcionamento do Conselho Nacional das Cidades, o governo municipal aprovou algumas resoluções, dentre as quais a Resolução no 48, de 16 de setembro de 2010, que, dentre outros 
aspectos, regulou a aplicação dos critérios de elegibilidade, hierarquização, seleção e indicação dos beneficiários a ser atendida nas unidades habitacionais construídas através do Programa Minha Casa Minha Vida com recursos do (FAR) - Fundo de Arrendamento Residencial e determinou que a indicação de famílias se faria exclusivamente a partir de um cadastro unificado organizado pela SEHAB no âmbito de programas municipais.

A Resolução $\mathrm{CMH}$ № 50, expedida em 25 de novembro de 2010, autoriza a COHAB-SP a realizar um procedimento de credenciamento de entidades, que, por meio de um convênio, poderiam indicar parte da demanda habitacional dos programas federais e, na mesma operação, exercer o trabalho social de pré e pós ocupação dos empreendimentos. Nessa concepção, além de indicar parte da demanda, a participação das famílias se daria como uma espécie de prestação de serviços de organização social que incluía a orientação dos beneficiários acerca da documentação necessária à comercialização das unidades, processos pedagógicos de "preparação" da famílias para a nova rotina de vida em um empreendimento em regra com caráter de condomínio vertical, de promoção de ações sócio- educativas, em suma visa considerar que o papel da entidades seria equivalente ao de uma administradora de condomínios.

Ou seja, não faltaram propostas de regulamentação dos programas autogestionárias no período. Faltou, efetivamente, a execução necessária para demonstrar a sua viabilidade prática.

\subsubsection{A autogestão no governo Haddad.}

O terceiro governo municipal petista em 20 anos era portador de uma elaboração progressista baseada na ideia de combater as assimetrias geradas pelo histórico processo de exclusão social que marcou a urbanização da cidade, mas, para realiza-la, apoiou-se numa coligação política ${ }^{29}$ que revelava uma nova tática da esquerda, lastreada na construção de uma ampla base parlamentar que reunia, para além dos partidos de esquerda, também parte dos partidos de direita.

\footnotetext{
${ }^{29}$ O Prefeito Fernando Haddad foi eleito em 2012, como representante da Coligação "Para mudar e renovar São Paulo", formada pelos seguintes partidos políticos: PT, PC do B, PSB e PP. A coligação elegeu 16 vereadores, de um total de 55 que compõe a Câmara Municipal da cidade.
} 
No plano da política de desenvolvimento urbano, o período é marcado pela discussão de um novo PDE (Plano Diretor Estratégico) para a cidade. O instrumento, embora controverso, desenvolvido sempre sob forte desconfiança de vários setores da sociedade, buscou consolidar e dar auto aplicabilidade aos instrumentos urbanísticos previstos no Estatuto das Cidades e dar continuidade às estratégias já definidas no $\mathrm{PD}$ anterior.

No PDE A questão da habitação foi tratada como diretriz para o desenvolvimento urbano (Art. 6o objetivos específicos e na adoção de instrumentos adequados. Merece destaque a ressignificação das ZEIS (Zonas Especiais de Interesse Social), cujo conceito, grau de aplicabilidade e quantidade de áreas foram alterados. Ainda segundo ROSSETTO e BONDUKI (2017, ob. cit. pg. 212) para o atendimento de demanda por demarcação de novas ZEIS trazidas tantos por atores tradicionais organizados sob uma rede denominada Frente em Defesa da Cidade e reforçada pelo surgimento de novas organizações como o MTST (Movimento dos Trabalhadores Sem Teto) foi responsável por substancial ampliação da quantidade de áreas, pela revisão dos parâmetros urbanísticos de modo a compatibilizar a ampliação do potencial de aproveitamento com a necessária preservação ambiental e a destinação prioritária ao atendimento a famílias de menor renda.

O PDE também relacionou de forma pioneira o estímulo à produção social da moradia como diretriz da política habitacional.

A Secretaria de Habitação, de forma inédita em relação aos governos petistas anteriores, é atribuída aos integrantes do Partido Progressista, como parte de uma estratégia que buscava, basicamente, facilitar as condições de entendimento entre a administração e os agentes políticos do Ministério das Cidades e ao mesmo tempo sinalizar aos vereadores dos demais partidos que havia a disposição em constituir alianças políticas para ampliar a base de apoio do governo na Câmara Municipal. ${ }^{30}$

$O$ balanço de gestão que busca consolidar uma análise qualitativa do processo, produzido pela própria SEHAB (2016, p. 14-67) é transparente em relação ao objetivo da estratégia traçada:

\footnotetext{
${ }^{30} \mathrm{Na}$ época, o Ministério das Cidades do governo Dilma era ocupado por Mario Negromonte, sucedido por Aguinaldo Ribeiro, ambos do mesmo partido progressista que integrava a coligação municipal.
} 
"No campo da habitação, um dos principais desafios do Prefeito Fernando Haddad ao assumir seu mandato era conseguir estruturar uma Secretaria capaz de se alinhar com as políticas públicas elaboradas no plano federal desde 2009, que colocavam à disposição recursos financeiros necessários para a produção de habitacional de interesse social."

...

"uma cidade do porte de São Paulo deve ser capaz de estruturar um sistema de financiamento próprio para a manutenção da política em momentos de maiores dificuldades econômicas e de eventuais estrangulamentos dos recursos federais e/ou estaduais".

A decisão de cooperação entre os entes, em si, se alinha com a noção de competência concorrente para a elaboração de programas habitacionais e aparentemente estava absolutamente correta do ponto de vista da conjuntura econômica e política de então, de precariedade fiscal no âmbito municipal e pujança de recursos no âmbito federal, em razão de programas como o (PAC) - Programa de Aceleração do Crescimento e o próprio MCMV, mostrou-se, na realidade, uma promessa não cumprida, na medida em que, paulatinamente, especialmente a partir de 2014, o governo federal foi reduzindo a quantidade de unidades contratados. Ver Gráfico 4.

Os programas municipais da área da habitação, e dentre eles o programa de mutirões, continuaria no rol de programas habitacionais, especialmente porque haviam obras em andamento vindas de governos anteriores, mas claramente preteridos em relação à busca por participação no MCMV.

O programa de metas $^{31}$, elaborado pela gestão Haddad se estruturava a partir da premissa de que a realidade profundamente desigual da cidade decorria não apenas dos baixos investimentos realizados, mas principalmente pela má utilização dos mecanismos de planejamento. Daí a estratégia de reverter a situação a partir de uma ação territorial coordenada de maneira transversal na execução das políticas. Por isso, o programa de metas relacionou 123 metas agrupadas segundo três eixos temáticos (compromissos com os direitos sociais e civis, desenvolvimento

\footnotetext{
${ }^{31}$ O Programa de Metas é uma exigência da Lei Orgânica do Município de São Paulo desde 2008, ano no qual uma mobilização da sociedade civil conseguiu fazer com que a Câmara Municipal aprovasse a criação do Programa de Metas. A partir daquele momento, todo prefeito eleito tem a obrigação de apresentar, em até noventa dias após a sua posse, um Programa que descreva as prioridades de seu governo, explicitando as ações estratégicas, os indicadores e as metas quantitativas para cada um dos setores da administração pública municipal. Fonte: Prefeitura Municipal de São Paulo.
} 
econômico com redução das desigualdades e gestão descentralizada, participativa e transparente), que por sua vez, se desdobram em 20 objetivos estratégicos ${ }^{32}$.

Especificamente, em relação à política de habitação, no item "garantia acesso à moradia adequada", constou como compromisso, a construção de 55 mil unidades habitacionais nos programas de provisão habitacional, atender 70 mil famílias nos programas de urbanização de favelas e beneficiar 200 mil famílias nos programas de regularização fundiária.

Para a compreensão do período é necessário separar dois períodos muito distintos: o período inicial marcado caracterizado pela estratégia preponderante de vinculação ao governo federal, ocorrido entre 2013 e 2015 e o período final da gestão, especialmente no ano de 2016, marcado pela busca de estruturação de uma política municipal de habitação.

No primeiro período, o governo estabeleceu mecanismos institucionais para dar suporte aos programas habitacionais, seja por meio da reestruturação administrativa da SEHAB e da criação de uma secretaria específica para o licenciamento urbanístico dos empreendimentos da cidade, inclusive os de caráter habitacional, o que se deu por meio da Lei $n^{0}$ 15.764/2013, e pelo significativo conjunto de normas urbanísticas, onde merece destaque a aprovação de um novo Plano Diretor para a cidade, amplamente favorável à habitação social, de uma nova Lei de Zoneamento, do encaminhamento de um novo Código de Obras e de um Plano Municipal de Habitação.

No que diz respeito aos empreendimentos autogestionários, ainda no primeiro período, registra-se a prevalência da retomada do procedimento de chamamentos públicos por meio do lançamento de editais discutidos com as principais organizações dos movimentos de moradia. Os chamamentos tinham como objetivo a destinação de terrenos públicos ou em desapropriação pelo município a associações habilitadas pelo Ministério das Cidades, para produção habitacional com recursos do Programa Minha Casa Minha Vida Entidades.

A discussão da retomada dos chamamentos teve forte participação da União dos Movimentos de Moradia, cuja pressão fez constituir um grupo ligado à Secretaria Municipal de Relações Governamentais e à Secretaria Municipal de

\footnotetext{
${ }^{32}$ Fonte: Prefeitura Municipal de São Paulo: Programa de Metas participativo. Disponível em: https://www.prefeitura.sp.gov.br/cidade/secretarias/upload/planejamento/arquivos/15308004 AF FolhetoProgrmadeMetas2Fase.pdf. Acesso em 22/04/2020.
} 
Governo, que basicamente, reivindicavam a cessão de terrenos públicos, como contrapartida no âmbito do MCMV - E. Em geral, a terra representava cerca de 15\% do valor total dos empreendimentos, e, mais importante do que isso, eram praticamente inacessíveis aos movimentos de moradia que, dada a sua natureza não lucrativa, não possuem terras ou meios financeiros necessários à sua obtenção no mercado.

Figura 5 - Prefeito discursa em manifestação da UMM/SP, 2014

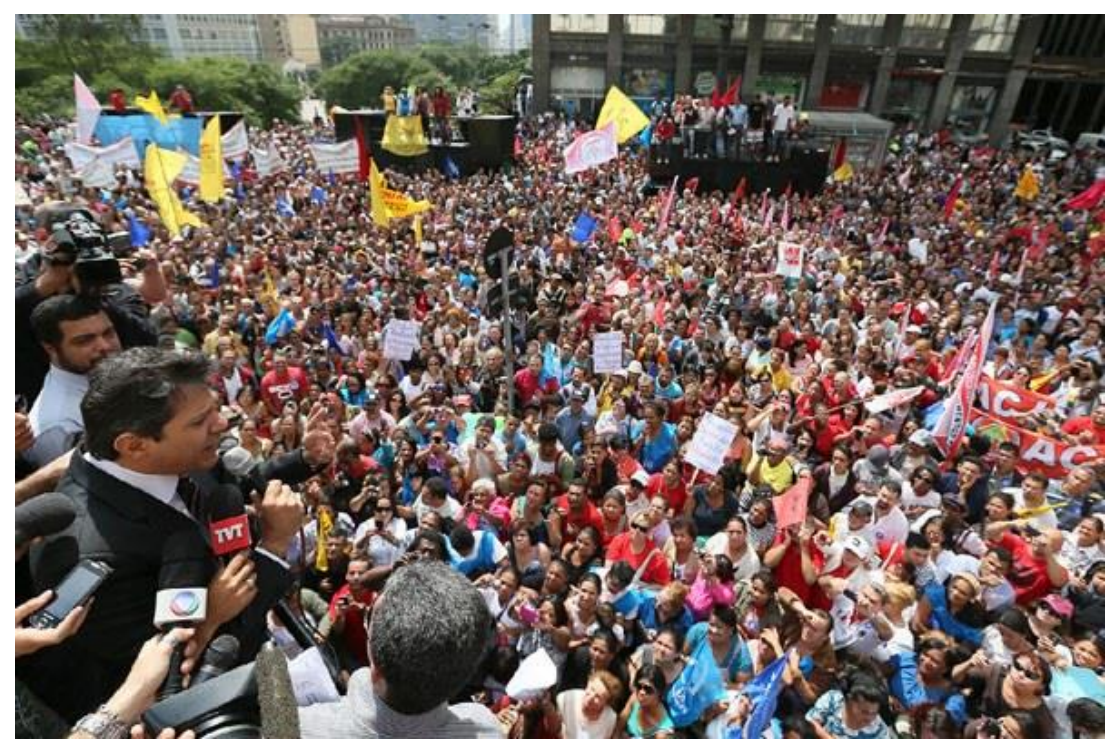

Foto: Cesar Ogata. SECOM/PMSP

A Resolução CMH oo 79 de 25 de outubro de 2016, autorizou a administração a transferir formalmente um conjunto de imóveis (terrenos ou prédios) diretamente para as entidades organizadoras representativas dos movimentos de moradia. A transferência se dava por meio de instrumentos juridicamente precários (cartas de anuência, termos de Vinculação e cessão de Posse Provisória) ou definitivos (Escritura de doação condiciona registrada na matrícula imobiliária). A situação merece registro, inclusive, porque historicamente a propriedade dos terrenos ficava em nome da administração e a comercialização era realizada diretamente com as famílias mutirantes.

Os procedimentos de seleção de entidades simbolizam o conjunto de preocupações jurídicas que se somaram historicamente ao longo do histórico dos projetos habitacionais, dentre os quais se destacam: (a) a necessidade de procedimento de licitação pública para a seleção de entidades para atuação no 
programa com a garantia ao cumprimento de todos os princípios decorrentes; (ii) o prévio licenciamento urbanístico e ambiental dos projetos; (iii)

Além dos programas da administração, no período também foi aprovada a Lei Municipal n 16.587, de 12 de dezembro de 2016, também de autoria do Vereador Nabil Bonduki, a partir de um debate com representantes dos principais atores dedicados aos processos autogestionários, em síntese, a lei se preocupa em regular os seguintes elementos: (i) buscar consolidar um conceito de autogestão; (ii) reconhece o protagonismo das famílias no controle do processo produtivo; (iii) caracteriza a modalidade como uma forma de provisão destinada ao atendimento das famílias de menor renda; (iv) admite a urbanização ou a regularização de assentamentos precárias de forma autogestionária; (v) estabelece a autonomia das associações para regulamentar conforme seus estatutos os processos de seleção das famílias, observados os princípios constitucionais e as competências do $\mathrm{CMH}$; (vi) dá parâmetros para a realização de procedimentos de seleção de projetos; (vi) autoriza a administração a criar um programa de autogestão na moradia e delineia seus principais procedimentos burocráticos; (vii) estabelece diretrizes políticas próximas daquelas desenhadas na época do FUNAPS Comunitário, ressaltando o respeito à autonomia das associações e cooperativas, a garantia ao acesso à moradia digna, a participação das famílias em todas as etapas do processo, o estímulo ao mutirão e à autogestão, a valorização do trabalho social, o estímulo às formas coletivas de fruição da posse ou da propriedade das unidades, dentre outras; (viii) define fontes de recursos, articulando as fontes orçamentárias com os recursos oriundos da aplicação dos instrumentos de indução ao desenvolvimento previstos no Plano Diretor da cidade; (ix) busca definir os agentes intervenientes e o seu papel no processo; (x) fixa o papel central do $\mathrm{CMH}$ como organismo responsável pelo detalhamento das regras de operação para além das definidas na própria lei, definindo as metas quadrienais de produção, os critérios territoriais para aplicação dos recursos financeiros no território, critérios para o enquadramento das entidades, critérios gerais para a seleção das famílias, critérios para a definição de parâmetros de qualidade dos projetos, modalidades construtivas (autogestão, co-gestão, etc.), formas de monitoramento dos resultados dos programas e formas de contratação;

FERREIRA e JUNCAL (2017) asseveram que a COHAB disponibilizou 124 terrenos ou imóveis, 42 na modalidade FAR-Empresas/Faixa 1, com potencial para a construção de 16.361 unidades, e outros 82 na modalidade FDS-Entidades/Faixa 1, 
correspondendo a um potencial de mais 13.143 unidades habitacionais. Entretanto, no caso dos projetos autogestionários, a transferência efetiva dos terrenos (condição para contratação no PMCV-E) ocorreu apenas no final do segundo semestre da gestão, de modo que, embora relevante porque disponibilizaram os terrenos, a ação não se materializou em contratações até o final da gestão ${ }^{33}$. Além disso, essa destinação ocorreu no momento em que o programa federal já estava em declínio de seu número de contratações, como será exposto à frente.

\section{4 Autogestão e Governo do Estado. Os mutirões da CDHU.}

A política de habitação no âmbito do governo estadual historicamente como braço operacional a Companhia de Desenvolvimento Habitacional e Urbano do Estado de São Paulo, também designada, conforme seus Estatutos Sociais, pela sigla "CDHU"34. Além disso, a partir de setembro de 2011, foi instituída a agência Casa Paulista, na Secretaria de Estado da Habitação, para fomentar e executar programas e ações na área de habitação de interesse social do Estado.

Entretanto, a história da intervenção do Governo do Estado na habitação popular remonta, em termos institucionais, à década de 40 do século $\mathrm{XX}$, e efetivamente aos idos de 1967, quando a CECAP - Companhia Estadual de Casas Populares - inicia a produção de habitações para a população de baixa renda. Os passos iniciais da ação da empresa contemplavam ações na linha da comercialização de unidades ou de lotes urbanizados no âmbito dos programas desenvolvidos pelo BNH e pelo SFH. (DENIZO, 2007, p. 103).

Nas ações de produção habitacional prevaleceu, contudo, a modalidade de construção por empreitada ${ }^{35}$, em relação à qual, eram dirigidas críticas idênticas às

\footnotetext{
${ }^{33}$ No primeiro ano da administração seguinte, em continuidade ao trabalho anterior foram contratadas algumas obras relevantes como os empreendimentos Lord, Cambridge, Igarapé do Índio e Igarapé do Frade. Os demais terrenos tendem a ser absorvidos no programa "Pode Entrar", recentemente lançado pela Prefeitura Municipal.

34 A CDHU é uma empresa pública, criada sob a forma de sociedade anônima, parte integrante da administração indireta do Estado de São Paulo.

${ }^{35} \mathrm{O}$ conceito de empreitada, em termos jurídicos, está regulado nos artigos do Código Civil Brasileiro (art. 610 e seguintes) e corresponde, sinteticamente, a modalidade de contratação na qual uma parte (empreiteiro) se obriga, sem subordinação, a executar uma obra para a outra parte (proprietário, comitente), em troca de um pagamento em dinheiro. A Lei Federal 8.666/93, conhecida como Lei das Licitações, determina que a empreitada poderá ser: a) empreitada por preço global; b)empreitada integral; c) empreitada por preço unitário.
} 
que os movimentos de moradia e técnicos faziam em relação à produção habitacional pública em geral.

Neste contexto, um conjunto de eventos foi consolidando a ideia de que também no âmbito estadual seria necessário desenvolver um programa nos moldes do FUNAPS Comunitário para atender a pressão constante dos movimentos de moradia.

A experiência autogestionária pioneira no âmbito da empresa está consolidada no empreendimento denominado Vila Comunitária de São Bernardo do Campo $^{36}$, executada em 1983, que incluía o elemento do mutirão, mas ainda era embrionária em termos de reconhecimento da autonomia da associação, na medida em que pouco contemplava a ideia de autogestão.

A primeira grande ocupação da Fazenda da Juta ocorreu no início de 1988, na região lesta da cidade de São Paulo e coordenada pelo MST Leste 1 e articulava a pressão por meio de ação direta com a proposta de construção em regime de mutirão com autogestão. No caso, inicialmente um acordo foi celebrado - com a atuação decisiva do Bispo Auxiliar da região Belém, Dom Luciano Mendes de Almeida - e as famílias deixaram a área, com o compromisso de que a CDHU o desapropriaria e o destinaria para o movimento construir as moradias. $\mathrm{O}$ acordo foi frustrado pela inércia do governo estadual e cerca de três anos depois, após uma nova ocupação, um novo acordo foi celebrado para a construção de 512 unidades habitacionais. Em uma operação que envolvia o governo estadual (por meio da $\mathrm{CDHU}$ ) que aportou o terreno e a Prefeitura Municipal (por meio da SEHAB) que aportou os recursos necessários para a construção.

Em 1991, após intensa pressão da UMM SP, o governador Fleury criou um programa piloto, que informalmente se chamava Programa Mutirão UMM, e que contratou empreendimentos em diversas regiões da capital e em Osasco, com regulação ainda bastante precária.

Essas experiências motivaram o desenvolvimento de uma institucionalidade voltada para a viabilização de projetos habitacionais produzidos em regime de mutirão com autogestão até então inexistente na Companhia (DENIZO, 2007, p. 151; BARROS, 2011, p.69). Para DENIZO:

\footnotetext{
${ }^{36}$ O empreendimento pioneiro, conforme Royer (2002, pg.137), foi executado no âmbito no Programa São Bernardo em parceria com a Associação de Construção Comunitária por Mutirão - ACCM.
} 
"O programa de Mutirão-UMM se introduziu na CDHU como um programa piloto, exigindo da CIA a criação de novos procedimentos de acompanhamento técnico e social, de prestação de contas, análise e aprovação de projetos contratados pelas associações, controle e gestão da produção habitacional, entre outros."

O programa piloto em seguida foi ampliado, ganhou "status" de programa na gestão do governador Mario Covas (1995-1998) e se transformou no Programa Paulista de Mutirões até que inicia seu declínio ${ }^{37}$.

Desse esforço, resultaram um conjunto de normas que compõe o quadro institucional dos programas estaduais de habitação em regime de mutirão com autogestão.

A Lei Estadual nำ 6.556/89 não se relacionava diretamente com a produção em regime de mutirão com autogestão, mas foi relevante para prover os recursos necessários ao desenvolvimento de programas alternativos aos que eram historicamente realizados pela Companhia. Para os movimentos de moradia ligados à UMM, inclusive, no nascimento, representava mais uma concessão do então governador Orestes Quércia, para as empresas construtoras, como se verifica no jornal da entidade, publicado em agosto de 1994:

"O Governador Orestes Quércia, pressionado pelas empreiteiras, aumentou a alíquota do ICMS e começou um programa de habitação voltado para as empreiteiras e os prefeitos que o apoiavam. Para Quércia, o movimento só atrapalhava e secretário de habitação dizia que o povo não sabia fazer uma parede que ficasse em pé"

Ela elevou a alíquota do Imposto obre Operações Relativas à Circulação de Mercadorias e sobre Prestações de Serviços de Transporte Interestadual e Intermunicipal e de Comunicação - ICMS de 17\% - para 18\% (art.3ํ), estabeleceu como diretriz para a execução orçamentária que o resultado dessa ampliação seria destinado ao aumento do capital da Nossa Caixa ${ }^{38}$, (art. 4º), vinculou a aplicação dos recursos para a finalidade habitacional de baixa renda em programas desenvolvidos pela CDHU. (arts. 5ำ 6ํㅜ $7^{\circ}$ ).

\footnotetext{
${ }^{37}$ Em 2007 a CDHU criou um programa destinado à construção com a participação de entidades, denominado "Gestão Compartilhada". No entanto, o programa está paralisado e sem perspectiva de retomada.

${ }^{38}$ A Nossa Caixa foi um banco público brasileiro, originário das caixas econômicas paulistas, fundado em 30 de dezembro de 1916 e encerrado oficialmente em 30 de novembro de 2009, quando foi incorporado ao Banco do Brasil.
} 
Em 1997 houve um questionamento jurídico sobre a legalidade da vinculação de recursos previstos nessa lei. Por meio de uma ação direta de inconstitucionalidade, obteve-se uma decisão judicial que desconstituiu o modelo ${ }^{39}$. A partir daí, com maior fragilidade política, aprova-se anualmente a elevação da alíquota, mas sem a vinculação, de modo que paulatinamente, os recursos foram sendo destinados às outras ações de Estado.

A Lei Estadual ํㅜ 6756/90 criou o Fundo de Financiamento e Investimento para o Desenvolvimento Habitacional e Urbano, conhecido como Fundo Estadual de Habitação (Art. $1^{\circ}$ ), qualificou o significado do direito à moradia na medida em que incorporou como objetivo dos projetos a noção de "geração de condições de vida adequadas à população de diferentes níveis de renda, viabilizando o acesso à habitação e serviços urbanos (Art. $2^{\circ}$ ), criou a figura de um conselho de orientação, composto por membros do governo e representantes dos acionistas da Nossa Caixa Nosso Banco (com previsão de que parte deles deveriam ser adquirentes de unidades), reafirmou as atribuições da CDHU para as atividades de análise e fiscalização dos projetos (funções que também deveriam ser exercidas pelas entidades populares, nos termos da Lei dos Mutirões), dentre outras previsões. A gestão financeira do Fundo ficou delegada à Nossa Caixa Nosso Banco e o fundo seria constituído por recursos oriundos das dotações orçamentárias estaduais, das contribuições e doações de pessoas jurídicas de direito público e privado, das contribuições e doações de organismos internacionais, dos recursos financeiros obtidos mediante a colocação de quotas ou certificados de participação, das rendas advindas dos imóveis ou bens de propriedade da Administração Centralizada ou Descentralizada estadual e/ou municipal que the venham a ser transferidos, dos terrenos de propriedade privada, de pessoas físicas ou jurídicas, que lhe fossem transferidos, dos recursos financeiros provenientes do orçamento fiscal do Estado e Municípios, destinados à execução de obras de infraestrutura e equipamentos urbanos e comunitários de sua responsabilidade, dos recursos financeiros provenientes de adquirentes que desejem usar seu depósito do Fundo de Garantia

\footnotetext{
${ }^{39}$ ADIN - STF no 213.739 de 10/06/1997. Posteriormente, a Reslução do Senado Federal ํo 7 de $21 / 06 / 2007$ suspendeu a execução dos artigos $3^{\circ}, 4^{\circ}, 5^{\circ}, 6^{\circ}, 7^{\circ}, 8^{\circ}$ e $9^{\circ}$ da Lei $n^{\circ} 6.556$, de 30 de novembro de 1989, e das Leis nos 7.003, de 27 de dezembro de 1990; 7.646, de 26 de dezembro de 1991; e 8.207, de 30 de dezembro de 1992, todas do Estado de São Paulo.
} 
por Tempo de Serviço como poupança ou parte de pagamento de habitação própria junto ao Fundo, dentre outras fontes eventuais.

A Lei tomou ainda outros cuidados para garantir a possibilidade de constituir um patrimônio cujos bens pudessem ser utilizados nos programas habitacionais, garantir a aplicação dos recursos integralmente em projetos de habitação de interesse social e criar mecanismos de gestão da comercialização das unidades decorrentes.

A Lei Estadual no 9.142/95, elaborada com ampla participação popular, decore do PL № 138/1991 e foi apresentada pelo então Deputado Estadual Roberto Gouveia (PT), tendo sido aprovada por unanimidade de votos. Conhecida como lei dos mutirões, destinou parte (10\%) dos recursos alocados no Fundo Estadual de Habitação para os empreendimentos desenvolvidos por associações comunitárias de construção ou cooperativas habitacionais (art. $1^{\circ}$ ), ampliou a possibilidade de utilização dos recursos que estavam restritos à produção habitacional para o uso em outras modalidades de ações habitacionais, como lotes urbanizados, urbanização de favelas, intervenções em cortiços, reformas de unidades habitacionais e equipamentos comunitários (Art. $1^{\circ}, \S^{\circ}$ ), buscou simplificar o procedimento de contratação (Art. $2^{\circ}$ ), determinou a competência da CDHU para a execução dos programas (Art. $4^{\circ}$ ) e reafirmou o grau de autonomia das entidades para que determinassem a forma de gestão dos recursos, com a devida prestação de contas, a execução da obra no regime de mutirão e com a liberdade para a contratação da equipe de assessoria técnica (Art.6\%).

A Lei Estadual no Lei 10.535/2000, também de autoria de Roberto Gouveia, conhecida como Lei da compra da terra, visava disponibilizar uma linha de crédito para a compra da terra para projetos autogestionários, por meio de associações representativas dos futuros moradores. Ela define como fontes de financiamento os recursos advindos da sobretaxação de ICMS e eventuais operações de crédito realizados pelo governo estadual, regulamenta os documentos que as entidades deveriam providenciar para acessar aos recursos, numa preocupação com a operacionalização do programa e determina que a relação será regulada por um convênio entre a CDHU e a entidade interessada.

A estrutura institucional arquitetada na CDHU na fase inicial do Programa de Mutirões - UMM não tinha uma preocupação explícita com o controle do processo de seleção das entidades, dado que o programa era uma resposta política às 
reivindicações do movimento, mas na gestão dos contratos, priorizava o detalhamento do fluxo de liberação de recursos, da forma de prestação de contas, optando por um modelo burocrático de controle de notas fiscais. Posteriormente, no Programa Paulista de Mutirões, novos procedimentos de contratação de terceiros sob a alegação de necessidade de aumento da produtividade, introduziram questões relacionadas aos processos licitatórios e de controle da qualidade dos serviços prestados.

Em termos quantitativos, os programas de mutirão construíram cerca de 3040 unidades habitacionais no Programa Mutirão UMM e 13.392 unidades no Programa Paulista de Mutirão (ROYER, 2002, p. 72 e p. 132), demonstrando que embora o período tenha sido marcado por constante enfrentamento entre os atores envolvidos, ainda assim, há um conjunto relevante de empreendimentos produzidos.

O programa de Mutirões da CDHU, inicialmente muito inspirado no programa de mutirões da Prefeitura de São Paulo, ao longo do tempo foi sendo limitado a tal ponto de se transformar numa forma de produção muito próxima da produção convencional por empreitada.

A pesquisa de ROYER (2002, p. 103), constatou a partir da análise dos documentos oficiais da empresa que, dentre as alegações para sustentar a limitação, estão o limite de escala, pela insuficiência de equipes técnicas, a ausência de atuação das administrações municipais, em contraponto ao que ocorria nos programas anteriores da Companhia, além de questões já abordadas, relativas ao grau de autonomia das associações no processo de produção, com a indicação da demanda e das assessorias técnicas. 


\section{3 - Autogestão e produção social da moradia}

O termo Produção Social da Moradia é o gênero que comporta dentro de si diversos sistemas construtivos: a autoconstrução privada formal, quando o futuro morador com esforço próprio executa sua moradia com a participação de profissionais e anuência do Poder Público, a autoconstrução informal, possivelmente a forma majoritária em que a população de menor renda acessa a moradia, sem o auxílio de profissionais ou Poder Público, os sistemas de mutirão em diferentes graus de participação que pode variar de experiências que prescindem do trabalho físico, como ocorre nas modalidades de empreitada global, ou, finalmente, os mutirões autogestionários, cuja característica central é a participação dos futuros moradores em todas as etapas do processo, passando pela escolha do terreno, pelo desenvolvimento de métodos participativos de discussão de projeto, pela administração e execução das obras e pela definição da forma de organização comunitária posterior à ocupação.

Portanto, embora o termo Produção Social da Moradia abarque distintas concepções e graus diferenciados de participação dos beneficiários nos processos decisórios, há razoável entendimento de que ele se diferencia das demais na medida em que pode viabilizar formas participativas de produção, de relações de trabalho nos canteiros de obras e na formação de níveis de consciência, entendidos na concepção desenvolvida por Paulo Freire ${ }^{40}$, necessários à obtenção de ganhos relacionados com a organização comunitária, especialmente da pós-ocupação dos empreendimentos e com construção da cidadania plena.

Para ORTIZ (2011, p. 26), entende-se por Produção Social da Moradia (PSM):

\footnotetext{
"aquela centrada na manifestação de uma nova cultura em que predominam a solidariedade, a ajuda mútua, a gratuidade e que gera uma convivência mais humana, harmônica e criativa."

"Ainda segundo o Autor a PSM: "Está se gerando, em diversas frentes, lugares e escalas o outro mundo possível que anima os
}

\footnotetext{
${ }^{40}$ Paulo Freire trata dos níveis de consciência em seu livro Pedagogia do oprimido, e consolida as categorias de análise no trabalho Ação cultural para a liberdade e outros escritos. O autor se apropria do instrumental de análise para estabelecer uma relação dialética entre a cultura do silêncio e a cultura dominante, cultura do silêncio entendida como aceitação das relações de dominação e o próprio reconhecimento de que há uma cultura dominante.
} 
sonhos e que imaginam e constroem passo a passo uma nova sociedade". (livre tradução do autor)".

"uma noção de construção de poder popular (...) de uma cultura de transformação, de desenvolvimento organizacional a partir da perspectiva de ser parte dos processos unitários do campo popular, para transformar a atual realidade socioeconômica e cultural e construir uma nova realidade"

GONZALEZ (2011, p.245) relaciona cinco eixos comuns aos países latinoamericanos e centrais para a efetivação de políticas permanentes que possam favorecer a PSM: "1. El fortalecimiento de los actores sociales; 2. La existencia de marcos legales adecuados; 3. Acceso al suelo; 4. Acceso a financiamento; 5 . La herramienta de la incidencia política". Para BALBIM e KRAUSE (2014), entretanto, a PSM:

"compreende as formas variadas de produção da habitação, que envolvem, em graus diversos, circuitos formais da economia, sejam públicos ou privados, mas que guardam a organização do processo e a definição das principais diretrizes do projeto e do pós-morar nas mãos e nos mecanismos de organização coletiva dos próprios moradores".

Anda segundo tais autores, no Brasil, a experiência da PSM, embora tenha cerca de 50 anos de história e exemplos de aplicação nos diversos programas desenvolvidos ao longo desse período, não deixou marcas relevantes na confrontação com a produção convencional de habitação.

Ou seja, não há unanimidade em torno da viabilidade desse sistema de produção habitacional.

No entanto, para os principais movimentos de moradia dedicados à construção da proposta de autogestão na moradia ${ }^{41}$, a pauta continua presente no cotidiano nas reivindicações, ainda que existam nuances em relação ao conteúdo que cada uma delas atribui ao termo.

A produção social da moradia é realizada sem finalidade lucrativa, ainda que inserida no contexto da produção capitalista e responde principalmente as demandas da população de menor renda.

\footnotetext{
${ }^{41}$ Nesse ponto nos referimos as entidades de caráter nacional mais relevantes do cenário político, quais sejam: UNMP - (União Nacional por Moradia Popular); CONAM - (Confederação Nacional de Associação de Moradores); (iii) CMP - (Central dos Movimentos Populares); MNLM - (Movimento Nacional de Luta pela Moradia); e: MTST - (Movimento dos Trabalhadores Sem Teto).
} 
Em vez de estimulá-la, o que se tem visto é a imposição de limitações e até mesmo de uma espécie de "criminalização burocrática" de seus agentes.

\subsection{A busca por um conceito de autogestão da moradia.}

Como já dito no capítulo anterior, o quadro de crise econômica nos anos 80 , aliado aos processos de retomada da mobilização social urbana estão na origem da formação dos movimentos de luta por mutirão com autogestão que combinavam a critica ao sistema vigente com a busca de soluções concretas para suas necessidades.

Assim, inspirados pelas novas formas de mobilização e a partir dos estímulos dos assessores técnicos e agentes pastorais da igreja católica, ocorreu uma preocupação com o processo de produção realizado de forma autônoma, o quanto mais livre possível da ingerência do Estado e das empresas privadas.

Portanto, conforme BONDUKI (1992, p. 33) o surgimento de propostas autogestionárias nasceu a partir do reconhecimento de que a mera ocupação de terras que seria capaz de resolver definitivamente os problemas habitacionais. A isso deve ser somada a experiência do cooperativismo uruguaio, que na época já havia construído milhares de moradia em regime de ajuda mútua através de cooperativas habitacionais. O autor relata as principais bandeiras de luta dessas organizações e merece que sejam reproduzidas (BONDUKI, 1992, ob. cit. p. 41):

"As propostas básicas dos movimentos de conquista de moradia são formuladas neste período. Suas linhas gerais são as seguintes: formação de entidade representativa da comunidade organizada, encarregada de promover e gerir todas as etapas do empreendimento habitacional, a obtenção da terra com recursos governamentais, a serem repassados às entidades a custo zero, obtenção de financiamento compatível com a renda em torno de um salário mínimo, para a compra do material de construção suficiente para a construção de uma casa com aproximadamente 42m2, construção da casa através da utilização, ao menos em parte, da mão de obra da própria comunidade organizada em mutirões coletivos, subsídio para a execução da infraestrutura, gestão pela entidade de todo o processo de escolha e compra do material, constituição de equipe técnica de confiança da comunidade para assessorá-la na elaboração do projeto, no controle e organização da obra e nos contatos com os órgãos públicos". 
A par disso, é possível ver traços trazidos da concepção cooperativista ou socialista do início do século XIX, que, conforme a afirmação de CANÇADO (2009), caracteriza-se como: um modelo de organização em que o relacionamento e as atividades econômicas combinam propriedade e ou controle efetivo dos meios de produção com participação democrática na gestão, que se contrapõe à forma heterogestão, vista como a forma tradicional de desenvolvimento das relações verticalizadas de trabalho presentes na sociedade capitalista.

Numa primeira aproximação o termo autogestão reconhecido nos discurso dos principais movimentos de moradia pode ser considerado, conforme a definição de RODRIGUES (2013, p. 31) como "um processo de gestão do empreendimento habitacional no qual os futuros moradores, organizados em associações ou cooperativas, administram a construção da moradia em todos os seus aspectos".

A Lei Municipal no 16.587/16 da cidade de São Paulo buscou conceituar a autogestão na moradia, fazendo-o nos seguintes termos:

\begin{abstract}
"Entende-se por autogestão na produção da moradia o processo construtivo em que as famílias participantes, organizadas numa associação ou cooperativa habitacional e com auxilio de assessoria técnica regularmente cadastrada realizam - em regime de democracia direta - as etapas de concepção, planejamento, desenvolvimento e execução dos projetos habitacionais e do trabalho social, exercendo todas a atividades de administração da obra e de definição da forma de organização da pós ocupação".
\end{abstract}

Como existem processos que se utilizam de todos os elementos do processo autogestionário, diretamente ou mesmo por meio da contratação de terceiros e outros processos que se utilizam de poucos dos elementos, podemos especular sobre a oportunidade de utilização de cada um deles em cada contexto histórico. Isso se torna relevante no contexto do MCMV-E entidades, dado que, como veremos, muitas em muitas situações a autogestão sofreu constrangimentos em detrimento de formas tradicionais de produção.

\title{
3.2. Características da participação autogestionária.
}

Enquanto na experiência que serviu de paradigma para os projetos autogestionários desenvolvida pela FUCVAM no Uruguai se utiliza da forma cooperativa para viabilizar seus projetos habitacionais (BONDUKI (1992); PESSINA 
(2003); BARAVAELLI (2006), no Brasil, prevalece a forma jurídica das associações sem fins lucrativos ${ }^{42}$.

É razoável supor que a simples existência de uma estrutura associativa não significa necessariamente um avanço democrático ou garantia de ampliação de direitos. Como parte da sociedade, elas também reverberam os valores gerais que a sociedade expressa.

Um aspecto de relevante que integra o processo de produção autogestionária é a institucionalização por meio da constituição de associações sem fins lucrativos. A possibilidade de organização de instituições de caráter público não estatal está presentes na legislação brasileira desde o código civil de 1916. Na atual redação foi regulada nos seguintes termos:

Art. 44. São pessoas jurídicas de direito privado:

I - as associações;

II - as sociedades;

III - as fundações.

IV - as organizações religiosas; (Incluído pela Lei no 10.825 , de 22.12.2003)

V - os partidos políticos. (Incluído pela Lei no 10.825 , de 22.12.2003)

$\mathrm{VI}$ - as empresas individuais de responsabilidade limitada. (Incluído pela Lei no 12.441, de 2011) (Vigência)

§ 1 ㅇão livres a criação, a organização, a estruturação interna e o funcionamento das organizações religiosas, sendo vedado ao poder público negar-lhes reconhecimento ou registro dos atos constitutivos e necessários ao seu funcionamento. (Incluído pela Lei ํㅜ 10.825, de 22.12.2003)

$\S 2{ }^{\circ}$ As disposições concernentes às associações aplicam-se subsidiariamente às sociedades que são objeto do Livro II da Parte Especial deste Código. (Incluído pela Lei no 10.825, de 22.12.2003)

$\S 3$-Os partidos políticos serão organizados e funcionarão conforme o disposto em lei específica. (Incluído pela Lei ํㅜ 10.825, de $\underline{22.12 .2003)}$

$\mathrm{Na}$ interpretação contemporânea, as associações propiciam a reunião de pessoas em caráter formal para a prática de atividades lícitas sem fins lucrativos com objetivos altruísticos. A reunião indica uma capacidade mobilização social. A formalização por meio de Estatutos Sociais confere a necessária estabilidade

\footnotetext{
${ }^{42}$ O cooperativismo habitacional uruguaio surgiu a partir de 1966 com algumas experiências realizadas por grupos assessorados pela CCU (Centro Cooperativista Uruguaio), uma espécie de organização de assessoria técnica que estimulou a formação de cooperativas de consumo. Em 1968, conquistou-se a Lei Nacional de Habitação naquele país. Em síntese, a lei unificou as decisões de política habitacional, consolidou os mecanismos de funcionamento e criou o Fundo Nacional de Habitação e eleva as cooperativas à condição de agentes promotoras de habitação. $O$ trabalho de Baravelli (2006) detalha o funcionamento do programa.
} 
das regras de convivência estabelecidas democraticamente entre os associados. O exercício de atividades lícitas é o requisito subjetivo, intrínseco a sua natureza. A ausência de finalidade lucrativa de um lado reflete o fato de que os associados não podem obter lucro a partir de suas atividades, mas de outro, não afasta a utilidade das atividades econômicas que ela desenvolve. E, finalmente, os objetivos altruísticos revelam a dimensão da solidariedade no trata para com a sociedade.

Entretanto, sua consolidação como ator político no processo de formulação e execução de políticas sobre variações significativas conforme o período e a região do país que se quiser avaliar.

BASTOS (1999, p. 168), elenca os motivos para seu desenvolvimento tardio em termos históricos a partir das seguintes constatações: (i) os governos temiam as facilidades de contestação que as liberdades publicas proporcionavam; (ii) as liberdades públicas não tem herança ideológicas na Declaração de Direitos dos Homens de 1789 de caráter marcadamente individualista; (iii) o liberalismo político temia entidades que pudessem postar entre o indivíduo e a coletividade total, deturpando a "vontade geral"; e (iv) o liberalismo econômico desconfiava das associações pelo prejuízos que poderiam trazer a uma economia de mercado, fundada em contratos individuais e na livre concorrência.

Nos processos de produção autogestionária da moradia, o associativismo encarna um aspecto produtivo evidente, especialmente a partir da celebração de convênios com a administração pública submetida a um conjunto de regras de controle necessários ao cumprimento da legalidade dos processos.

STORTO (2014, p. 40) chama a atenção para três aspectos fundamentais para o exercício das atividades associativas: (i) não interferência; traduzida no direito subjetivo de mantê-las protegidas de interferência não justificada pelo Estado; (ii) participação, traduzida no direito de representação coletiva, seja para integrar programa público ou para promover medidas judiciais de caráter coletivo; (iii) financiamento, traduzido no conceito de contratualização, que numa de suas vertentes implica no direito de demandar ao Estado que execute políticas públicas em parceria com as associações. 


\subsection{Autogestão e Cooperativismo}

No contexto contemporâneo, o conceito de cooperativa deve ser interpretado a partir da definição aprovada no Congresso de Manchester, no ano de 1995, segundo o qual a cooperativa "é uma associação autônoma de pessoas que se unem, voluntariamente, para satisfazer aspirações e necessidades econômicas, sociais e culturais comuns, por meio de uma empresa de propriedade coletiva e democraticamente gerida".

BUCCI (2003, p. 81-90) revela que o desenvolvimento cooperativista brasileiro difere frontalmente do paradigma uruguaio. No caso brasileiro, as iniciativas nascem de "cima pra baixo", sob forte controle estatal e constrangido por regramentos que paulatinamente foram desnaturando a finalidade original das entidades. Se a primeira regra estabelecida para disciplinar o funcionamento das cooperativas, Ihe reservava um papel relevante no conjunto de estratégias para o enfrentamento do déficit habitacional ${ }^{43}$, paulatinamente foram sendo constrangidas por regramentos seja pela ampliação do controle estatal - que chegava em alguns casos a prever a aprovação dos Estatutos por órgão do BNH - passando pela constituição de cooperativas dependentes de construtoras ou vinculadas à sindicatos submetidos à legislação de orientação fascista. Dentre os diversos aspectos mencionados pela autora, um deles parece estar presente desde a gênese do processo associativo cooperativista brasileiro: embora apresentado como portador de valores relacionados com a solidariedade e a justiça social, os processos tenderam a cooptação por interesses privados ou por interesses políticos da administração de turno. A utilização das cooperativas habitacionais como mera fachada para o acesso ao crédito público continua como uma prática que embaralhou as relações do MCVM-E.

Com a Constituição Federal de 1988 houve a liberalização compatível com a nova ordem principiológica baseada na democratização das relações sociais, Por meio do prestígio à liberdade de profissional e de atividades relacionadas e determinando que as legislações buscassem estimulá-las e outros estímulos

\footnotetext{
${ }^{43}$ A autora constata, com apoio dos ensinamentos de Bulgarelli, que ainda na gestão de Sandra Cavalcanti, o BNH baixou a Instrução no 01 em 30/11/1964, que por sua vez, além de fixar normas para o registro, funcionamento e fiscalização das cooperativas para a construção ou aquisição da moradia, ressaltava suas qualidades: caráter não lucrativo, popular, com possibilidade de filiação ilimitada, participação do sócios, votos singulares, etc.
} 
presentes em políticas específicas determinadas pelo texto, mas por outro, com o encerramento das atividades do $\mathrm{BNH}$, limitou sensivelmente a possibilidade de obtenção de recursos financeiros para a continuidade das atividades. ${ }^{44}$

Novamente com apoio na pesquisa de BUCCI (2003, ob. cit. p. 165) é possível afirmar que, além desses motivos preponderantes, outros aspectos devem ser considerados: (i) necessidade de poupança prévia dos próprios sócios em geral complementados por aportes de fundos públicos; (ii) normatização insuficiente. A autora ainda ressalta 0 fato de que a própria legislação do SFH criava constrangimentos à viabilidade da cooperativa na medida em que impunha, que, uma vez comercializados os empreendimentos, deveriam as cooperativas encerrar sua atividade, deixando de existir juridicamente.

A motivação para que pessoas se unam em torno de uma cooperativa vem do senso ético da solidariedade e da ajuda mútua e nisso ela difere de uma entidade de natureza empresarial.

DICKMANN (2018, p. 62) contrapõe ao modelo tradicional de cooperativismo que se estabeleceu no país um tipo ideal do que denomina como "cooperativismo autogestionário". Para o autor é possível relacionar os princípios cooperativistas como os elementos da autogestão com a educação popular e a economia solidária.

Finalmente, existem proposições no sentido de constituir uma legislação específica para reconfigurar o cooperativismo habitacional no pós Constituição de 1988.

A Lei Federal no 11.124/05 incluiu as cooperativas no rol de legitimados ao desenvolvimento de programas habitacionais no âmbito do SNHIS, nos seguintes termos:

Art. 5ํIntegram o Sistema Nacional de Habitação de Interesse Social - SNHIS os seguintes órgãos e entidades:

VII - fundações, sociedades, sindicatos, associações comunitárias, cooperativas habitacionais e quaisquer outras entidades privadas que desempenhem atividades na área habitacional, afins ou complementares, todos na condição de agentes promotores das ações no âmbito do SNHIS; e

VIII - agentes financeiros autorizados pelo Conselho Monetário Nacional a atuar no Sistema Financeiro da Habitação - SFH.

\footnotetext{
${ }^{44} \mathrm{O}$ estimulo ao cooperativismo ficou consagrado no texto constitucional em diversas passagens: (Art. 146, inciso III, letra "c", que determina aos Estados que Ihe confiram benefícios tributários; Art. 172 , §3ํำ e $4^{\circ}$ que favorem as cooperativas dedicadas à exploração de atividades minerárias; Art. 192 que inclui as cooperativas de crédito no rol de legitimados para atuação no mercado financeiro;
} 
A Lei Federal no 11.888/08, previu a posssibilidade de apoio financeiro para as atividades de assistência técnica gratuita:

Art. $3^{\circ}$ A garantia do direito previsto no art. $2^{\circ}$ desta Lei deve ser
efetivada mediante o apoio financeiro da União aos Estados, ao
Distrito Federal e aos Municípios para a execução de serviços
permanentes e gratuitos de assistência técnica nas áreas de
arquitetura, urbanismo e engenharia.
$\S 1^{\circ}$ A assistência técnica pode ser oferecida diretamente às famílias
ou a cooperativas, associações de moradores ou outros grupos
organizados que as representem.

As deficiências dos modelos anteriores, longe de invalidar o modelo cooperativista como um dos mecanismos de enfrentamento do problema habitacional incluiram na agenda dos movimentos a necessidade de construir regras legais capazes de estabelecer as condições adequadas de funcionamento no âmbito de uma nova política habitacional.

Embora sejam avanços relevantes, ainda restam outros aspectos que mereceriam regulamentação, quais sejam: (i) facilidades financeiras, que podem ser compreendidas como fontes permanentes de financiamento em condições favoráveis; (ii) incentivos fiscais, tais como isenção ou remissão de tributos que incidem sobre operações imobiliárias como é o caso do IPTU (Imposto sobre a propriedade Territoria Urbana) de âmbito municipal, o ITCM-D (Imposto de Transmissão Causa Mortis e Doação) de âmbito estadual) ou o IR (Imposto de Renda) de âmbito federal; (iii) maior flexibilidade para a criação e funcionamento das cooperativas; (iv) estímulo à adoção de requisitos urbanísticos especiais;

Para os movimentos de moradia, a Entendida como uma forma de organização cujos elementos centrais são a pessoalidade e a finalidade não lucrativa e considerando que sua atuação deve ser limitada aos empreendimentos pequenos e médios, não se admitindo nessa modalidade que o controle seja exercido por empresas capitalistas, caberia à proposta legislativa estabelecer um conjunto de princípios gerais para o enquadramento das propostas, tais como: posse coletiva dos meios de produção pelas pessoas que as utilizam para produzir; gestão democrática; o estímulo à participação direta dos futuros moradores; a soberania assemblear nos empreendimentos, dentre outros. 


\subsection{Autogestão e ajuda mútua.}

A participação dos "usuários ${ }^{45 "}$ ou dos futuros moradores no trabalho físico de produção da casa em geral, nos estudos localizados no campo da reforma urbana, sempre esteve associada aos processos de autoconstrução e de mutirão artesanal, característicos dos processos de construção de moradias nas periferias urbanas das grandes cidades. E sempre foi vista sob a reserva de que possivelmente se constitui como um dos elementos [ao lado dos baixos salários] que contribuem para a reprodução das desigualdades no interior do processo de acumulação capitalista. A afirmação clássica de OLIVEIRA, (2003, p. 59), por relevante, continua presente nos debates que dizem respeito ao tema:

"Uma não insignificante porcentagem das residências das classes
trabalhadoras foi construída pelos próprios proprietários, utilizando
dias de folga, fins de semana e formas de cooperação como mutirão.
Ora, a habitação, bem resultante dessa operação, se produz por
trabalho não pago, isto é, supertrabalho. Embora aparentemente
esse bem não seja desapropriado pelo setor privado da construção,
ele contribui para aumentar a taxa de exploração da força de
trabalho, pois seu resultado - a casa - reflete-se numa baixa
aparente do custo de reprodução da força de trabalho - de que os
gastos com habitação são um componente importante - e para
deprimir os salários reais pagos pelas empresas. Assim, uma
operação que é, na aparência, uma sobrevivência de práticas de
"economia natural" dentro das cidades, casa-se admiravelmente bem
com um processo de expansão capitalista, que tem em suas bases e
dinamismo na intensa exploração da força de trabalho."

MARICATO (1982, p. 71), por sua vez, se refere ao mutirão em meio urbano, no contexto da sociedade capitalista, como uma forma de solidariedade forçada, ainda que não the desmereça como estratégia possível não apenas para a construção da casa, mas para a construção de equipamentos de uso público minimamente necessários à garantia de alguma dignidade na vida urbana.

A noção de autoconstrução, trazida por RAMOS (2007, p. 40) segundo a qual a autoconstrução é um processo de produção de habitações pelo próprio habitante, geralmente realizada de forma isolada e sem a presença do Estado ajuda a compreender a celeuma.

\footnotetext{
${ }^{45}$ A influência de John Turner influenciou o debate sobre os caminhos da política de habitação desde os anos 60 no Brasil. No Brasil um continuador de suas ideias foi o arquiteto Carlos Nelson Coutinho que pode ser considerado um pioneiro da urbanização de favelas com participação popular.
} 
Entretanto, a ideia de mutirão ${ }^{46}$ como elemento constituinte dos processos autogestionários, não se pretende como parte do processo de acumulação capitalista, mas como parte de um processo de produção não mercantil da moradia.

No caso da autogestão, alguns governos progressistas premidos pelos contornos explosivos que a questão da moradia começava a assumir, resolveram liberar a título de urgência recursos próprios para a construção de moradia popular. Vários desses programas previam apenas o financiamento de materiais de construção, ficando a mão de obra por ser fornecida pelos próprios interessados em regime de ajuda mútua, fosse ela realizada em mutirão coletivo ou individual.

VELASCO, $(2018$, p. 65) registra que desde o início da prática do mutirão autogerido até os dias de hoje percebe-se uma mudança de metodologia de ação conforme alteração do contexto político. O canteiro mutirante como um local que originalmente possuía grande foco na mão de obra do mutirão como construtor efetivo das casas, passou a se transformar em um espaço com menor protagonismo dessas atividades de ajuda mútua e mais próximo de um canteiro tradicional da construção civil. Essa mudança aconteceu de forma gradual, no decorrer dos anos em que houve produção habitacional promovida pelos movimentos sociais.

Será, entretanto, uma pratica de mutirão adaptada às novas lógicas propostas pela nova configuração da divisão social do trabalho no pós-neoliberalismo.

\subsection{Autogestão e o marco legal da economia solidária.}

O tema da autogestão habitacional, por sua vez, se insere num contexto mais amplo, da denominada "Economia Solidária".

Termo polissêmico, para o Fórum Brasileiro de Economia Solidária ${ }^{47}$, o conceito de economia solidária pode ser definido em três dimensões: econômica, cultural e política, ou seja, tem caráter multidimensional.

No Brasil, se consolidaram historicamente na forma de cooperativas, associações de produtores, grupos informais, redes de cooperação solidária, entre

\footnotetext{
${ }^{46}$ O termo "mutirão" remete a ideia de mobilização coletiva para auxílio mútuo em caráter gratuito e vem sendo utilizado desde o início das experiências autogestionárias.

${ }^{47}$ Outros autores explicitam seu caráter técnico motivacional (GOLEMAN, 2015) que a concebe como forma de estimular a inteligência emocional do colaborador na busca por maior eficiência produtiva no interior de organizações capitalistas de produção e, finalmente, há outros ainda destacam, essencialmente, seu caráter político, como forma de organização da ação coletiva com vistas à transformação social (BARCELOS e LECHAT, 2008).
} 
outras formas de organização, ligada aos excluídos do processo de produção de caráter mercantil e das políticas públicas de geração de emprego, renda e desenvolvimento.

LAGO (2015, p. 02) busca relacionar o movimento de produção habitacional autogestionária com o movimento de economia solidária, e nesse esforço necessário afirma que ambos acionam em suas práticas discursivas o princípio da autogestão coletiva como a base para "uma outra economia" e "para uma outra cidade", respectivamente. Entenda-se a "outra economia" como anticapitalista e a "outra cidade" como democrática e des-mercantilizada. Ambos também pressupõem a disputa pela apropriação do fundo público e por sua regulação como condição para a legitimidade e difusão das experiências autogestionárias. A luta pela legitimação dessas experiências passou pela institucionalização dos dois movimentos com a criação, respectivamente, do Fórum Brasileiro de Economia Solidária (FBES) e do Fórum Nacional de Reforma Urbana (FNRU).

SILVA e SILVA (2015, p. 91) afirmam que apesar dos avanços os empreendimentos de economia solidária apresentam grandes fragilidades na organização da produção e da comercialização de seus produtos e serviços, com difícil acesso a conhecimentos (formação, assistência técnica e tecnologias) e ao crédito para investimentos e capital de giro, inclusive em decorrência do grau de informalidade desses empreendimentos.

Daí a mobilização social do movimento nacional da economia solidária para viabilizar a apreciação de marco legal para o setor.

A proposta define economia solidária como um conjunto de atividades de organização da produção e da comercialização de bens e de serviços, da distribuição, do consumo e do crédito, observada os princípios da autogestão, do comércio justo e solidário, da cooperação e da solidariedade, a gestão democrática e participativa, a distribuição equitativa das riquezas produzidas coletivamente, o desenvolvimento local, regional e territorial integrado e sustentável, o respeito aos ecossistemas, a preservação do meio ambiente e a valorização do ser humano, do trabalho e da cultura.

A análise do comportamento da economia solidária no campo das políticas públicas sinaliza claramente o modo incremental com que o temas relacionados às políticas contra hegemônicas vem se viabilizando no pais. 
Nesse contexto, quanto tais interesses esbarram nos dilemas próprios da relação em um campo de disputa de interesses bastante profundo, que exige uma importante capacidade de mediação política e de articulação de forças. 


\section{4 - O marco legal da política e dos programas autogestionários nos governos Lula e Dilma.}

O programa de governo do então candidato Luís Inácio Lula da Silva incluiu a chamada questão do desenvolvimento urbano no marco da construção de uma estratégia para o desenvolvimento da infraestrutura e desenvolvimento sustentável e registrou como parte da análise a compreensão segundo a qual embora o papel central para a solução dos problemas urbanos coubesse aos municípios, não se poderia afastar a responsabilidade do ente nacional.

As diretrizes iniciais que estruturaram o debate sobre a política habitacional do governo Lula foram consolidadas no documento denominado "Projeto Moradia". Organizado em parceria com a Fundação Djalma Guimarães. O Projeto Moradia foi concluído em maio de 2000 e apresentou soluções concretas para o problema do déficit habitacional no Brasil, a partir do conceito inovador de "moradia digna". Em, partiu das premissas de que os programas habitacionais deveriam permitir a democratização do acesso ao crédito, diversidade de programas e projetos e da participação das "famílias envolvidas" e tais premissas permitiram acolher a proposta de produção cooperativa e associativa. A produção associativa (que inclui cooperativas organizadas pela população de menor renda e, portanto, mais articulada com o ideário da economia solidária) e associações sem fins lucrativos seria aquela voltada à ação pública por meio da ampliação dos subsídios públicos repassados diretamente às entidades representativas dos movimentos sociais e comportaria também o estímulo à organização política dos beneficiários e, portanto, estaria mais associada à ideia de moradia como direito social autoaplicável.

Uma vez eleito para dar consequência a tal estratégia, foi criado o Ministério das Cidades que, conforme Maricato (2007):

\footnotetext{
"ocupou um vazio institucional que retirava o governo federal da discussão sobre a política urbana e o destino das cidades. Além da ausência da abordagem mais geral, havia a ausência de marcos institucionais ou regulatórios claros para as políticas setoriais urbanas, caso das áreas de saneamento, habitação e transporte. 0 Ministério das Cidades teve sua estrutura baseada nos três principais problemas sociais que afetam as populações urbanas e que estão relacionados ao território: a moradia, o saneamento ambiental (água, esgoto, drenagem e coleta e destinação de resíduos sólidos) e as questões do transporte da população urbana - mobilidade e trânsito".
} 
Como noutros momentos, optamos por atribuir aos governos do período o benefício de construir uma política pública ao mesmo tempo em que era necessário aplica-la.

Como referido por MOREIRA (2009, p. 77), o esforço tinha como desafio inovar em relação ao período imediatamente anterior, no qual as iniciativas de produção associativa para a população de menor renda tinham sido sufocadas por políticas fiscais restritivas. ${ }^{48}$

Como a análise do conjunto das políticas habitacionais desenvolvidas no período foge ao escopo dessa dissertação, necessário ao menos fixar algumas das questões relacionadas com os processos de produção autogestionária da moradia.

Do ponto de vista dos planos e programas públicos, a presença das possibilidades da execução de projetos com a participação de entidades representativas dos movimentos de moradia no processo de produção da moradia, está prevista no documento que instituía a PNH - (Política Nacional de Habitação), aprovado em 2004, realizada com base nas resoluções da $1^{\text {a }}$ Conferência Nacional das Cidades e aprovada no Conselho Nacional das Cidades.

Em síntese, a PNH estabelecia o arcabouço conceitual, estruturava institucionalmente as ações no campo da habitação a partir do Sistema Nacional de Habitação (SNH), identificava os agentes que atuariam na implementação da política, estabelecia os componentes e as linhas de ação que direcionavam os recursos e financiamentos habitacionais.

A partir de um diagnóstico da situação habitacional do país e estabeleceu diretrizes de atuação que, de um lado reconheciam o efeito vinculante do direito à moradia, indicando a necessidade de construção de um sistema nacional de habitação de interesse social e, por outro lado, ressaltou a importância da participação do setor privado na produção habitacional no segmento de mais baixa renda pela atuação das empresas ou das entidades representativas dos moradores. Diz o texto:

\footnotetext{
${ }^{48}$ Com apoio nos estudos desenvolvidos por SANTOS (1999), a autora registra que entre 1988 e 2001 foram desenvolvidos programas que objetivam atender a população de menor renda, foi a forma de estimular a sociedade a resolver seus problemas habitacionais, sem que houvesse, uma participação do Estado como agente produtor de novas moradias. Nessa linha, foram criados os programas: Carta de Crédito Individual, Carta de Crédito Associativo, o PAR (Programa de Arrendamento Residencial) e o PSH (Programa de Subsídio à Habitação de Interesse Social).
} 


\begin{abstract}
(...)
"A atuação do setor privado, de forma compartilhada com o setor público, permitirá a otimização econômica dos recursos públicos e privados investidos no setor habitacional, especialmente os recursos oriundos do FGTS que passariam a focalizar, preferencialmente, a faixa de renda até 05 salários mínimos. Assim, o componente provisão habitacional passa a compreender um conjunto de medidas a serem adotadas nos programas e linhas de atuação vigentes ou a serem criados, resultante das deliberações ocorridas na Conferência das Cidades, conforme se descreve a seguir: disponibilizar programas com créditos onerosos e subsidiados para ampliar o acesso da população de baixa renda a unidades habitacionais por meio da construção de novas unidades, produção de lotes urbanizados, promoção de melhorias e ampliações de domicílios existentes e a ocupação de unidades habitacionais vazias; implementar linhas de financiamento a pessoas físicas destinadas a: a aquisição de imóvel novo ou usado, construção em terreno próprio e construção por gestão associativa, incluindo terreno, material e projeto; e aquisição de materiais de construção com assessoria técnica para promoção de melhorias habitacionais e ampliação de unidades existentes; implementar linha de financiamento para cooperativas, associações autogestionárias, mutirões, sindicatos, organizações não-governamentais e outros agentes populares, com recursos onerosos e não onerosos; $(\ldots)$
\end{abstract}

A Política Nacional de Habitação propôs a universalização do acesso à moradia digna para todo cidadão, contribuiu com um processo participativo de elaboração de planos diretores municipais, com a constituição de conselhos e fundos municipais de habitação e orientou a formulação de um ambicioso Plano Nacional de Habitação, cujo detalhamento também reconhece o papel das entidades no processo de produção da moradia. Os movimentos de moradia foram atores fundamentais no processo de elaboração desta política.

\title{
4.1. O Plano Nacional de Habitação
}

O PLANAB (Plano Nacional de Habitação) estava relacionado como uma das ferramentas da PNH e surgiu como atribuição do Ministério da Cidades (Art. 14, III) em conformidade com as diretrizes de desenvolvimento urbano e em articulação com os planos estaduais, regionais e municipais de habitação.

Elaborado em 2009, o texto introdutório do chamado PLANAB reconhece a questão habitacional deve ser entendida como uma política de Estado, uma vez que 
o poder público é agente indispensável para a regulação urbana e do mercado imobiliário, e para a provisão da moradia e a regularização de assentamentos precários. Deve, portanto, ser uma política pactuada com a sociedade e que extrapole as gestões governamentais.

A partir de um objetivo geral de implementar o SNHIS (Sistema Nacional de Habitação de Interesse Social), criado na Lei no 11.124/05 e consolidar um modelo de política habitacional baseada na descentralização, articulação intergovernamental e Inter setorial, participação e controle social e, partir disso definiu como estratégia o fortalecimento do setor público e explicitar os papéis e competências ente subnacional.

O PLANHAB definiu propôs ainda a remodelagem de subsídios públicos, de modo a combinar recursos onerosos e recursos não onerosos, com vistas a ampliar - leque de programas passíveis de financiamento, que, estava associada à produção social da moradia, especialmente por meio do fornecimento de insumos à construção, incluindo lotes urbanizados, materiais de construção e assistência técnica.

O PLANHAB também reconheceu o papel das associações cooperativas e definiu entre suas diretrizes o estimulo à autogestão e à formação de cooperativas para a produção habitacional, garantindo-se a assistência técnica. Dentro da Linha Programática e de Atendimento para Produção e Aquisição da Habitação, o Plano prevê a construção de um Subprograma para Promoção por Autogestão de Unidades Habitacionais Urbanas, com o objetivo de "promover a oferta de unidades habitacionais urbanas destinadas aos Grupos de Atendimento 1 e 2 por meio da autogestão realizada por entidades privadas sem fins lucrativos (fundações, sociedades, sindicatos, associações comunitárias, cooperativas habitacionais, entre outros tipos de entidades) articuladas com agentes de assistência técnica, cuja atuação está amparada pela Lei 11.124/05. No entanto, a perspectiva de aplicação do PLANHAB, em tese favorável à execução de programas a partir das necessidades locais, foi superada pelo lançamento do MCMV e MCMV-E.

Entretanto, o que pode afirmar, e nesse sentido com diversos autores ${ }^{49}$, é que prevaleceu certa desarticulação entre as diretrizes da política e do PLANHAB, e os programas habitacionais executados, especialmente no que diz respeito ao MCMV.

\footnotetext{
${ }^{49}$ Nesse sentido: KRAUSE, BALBIM e NETO (2013), CAMARGO (2016), MOREIRA (2016), et. Al.
} 


\subsection{As regras do Programa Crédito Solidário}

O PCS (Programa Crédito Solidário) foi o primeiro programa habitacional de interesse social criado pela gestão do Presidente Lula. Até o MCMV-E, o Ministério das Cidades aprimorou os demais programas já existentes como o Programa de Subsídio Habitacional e a utilização de recursos do FGTS, com uma importante inovação, as Operações Coletivas, instrumento conhecido como Resolução FGTS 460, criado para conceder subsídios habitacionais junto com financiamento, através da utilização de recursos do patrimônio líquido do Fundo.

Nesse sentido, houve grande expectativa sobre o PCS e sua capacidade de levar financiamento habitacional diferenciado em relação às opções existentes até então no FGTS e ao baixo valor dos programas subsidiados existentes. Podemos dizer que o PCS teve uma "curva de aprendizagem", que consumiu algum tempo tanto para as entidades se apropriarem do programa, como de adaptação do Programa e de seus agentes públicos na sua efetivação. NAIME (2012, p. 77) registra o seguinte aspecto:

"Considerando as modificações que foram feitas ao longo da etapa de implementação, identifica-se uma forte dimensão de processo. 0 programa foi criado com normas que se mostraram difíceis, ou mesmo impossíveis de serem cumpridas. O normativo foi sofrendo diversas alterações ao longo da implementação do programa, conforme os problemas iam surgindo."

A autogestão envolve a ajuda mútua dos beneficiários finais na produção, gestão e manutenção dos empreendimentos habitacionais que podem ser de propriedade cooperativa. Esse regime de propriedade imobiliária poderá se efetivar a partir de adesões por parte dos moradores desses empreendimentos. No entanto, a participação da autogestão na política habitacional continuou residual. Apesar de não ser o único fator a ser analisado, é significativo o pequeno peso dos programas autogestionários no volume de recursos destinados e, em consequência, no número de unidades produzidas. Além disso, poucas ações para fortalecer a capacidade de gestão das associações e cooperativas foram realizadas, tornando o processo muito mais efetivo pela iniciativa das entidades do que de uma política efetiva para o setor. 
As diferenças mais marcantes entre os Programas Crédito Solidário e Minha Casa Minha Vida Entidades estão na forma de financiamento de cada um deles. Apesar de ambos estarem abrigados no Fundo de Desenvolvimento Social (FDS), a origem de seus recursos e a forma de concessão de financiamento são totalmente distintos. O PCS tem como recurso os próprios depósitos do FDS e o MCMV-E é baseado em recursos do Orçamento Geral da União repassados ao FDS, através da lei 11.977/2009.

O FDS foi criado em 1991, com recursos de aquisições compulsórias e voluntárias de cotas, por entidades financeiras, emitidas pelos Fundos de Aplicação Financeira (FAF) e pelo resultado de suas aplicações.

Trata-se de recurso oneroso, que tinha, porém, um patrimônio líquido significativo que pôde dar melhores condições aos financiamentos.

O PCS é um programa de financiamento, onde o beneficiário retorna integralmente o valor de investimento, em até 20 anos, sem taxa de juros, o que o torna uma exceção no panorama dos demais financiamentos habitacionais da época, podendo ser tomado por famílias de menor renda em relação, por exemplo, àquelas atendidas pelo FGTS.

No PCS 1 havia alguns encargos a serem pagos durante a obra, como a atualização monetária do financiamento e o seguro, o que resultou em desequilíbrio financeiro em diversas obras, já que as famílias encontraram dificuldades em arcar com tais pagamentos, especialmente os idosos que tinham premio de seguro com valores às vezes maiores que a própria prestação da moradia. Esse tema foi alvo de muitas reivindicações dos diversos movimentos. Uma das mudanças mais importantes do PCS 2 foi que o FDS passou a arcar também com esses custos.

Nesse sentido, é sintomático que dentre as preocupações que motivaram a criação do PCS tenham afirmado a importância de estimular o cooperativismo e o associativo habitacionais. No preâmbulo da Resolução nº3/04 do Conselho Curador do Fundo de Desenvolvimento Social - FDS, consta a seguinte determinação:

"Considerando que o estímulo ao regime de cooperativismo habitacional e ao princípio da ajuda mútua, são formas de garantir a participação da população como protagonistas na solução dos seus problemas habitacionais comuns, proporcionando-a dentro das necessidades e características com os usos e costumes locais". 
Nos processos de produção social da moradia, prevalece a noção de moradia como direito e não como propriedade, o protagonismo dos cidadãos em detrimento dos interesses empresariais envolvidos, a diversidade de modalidades construtivas, entre outros aspectos.

Enquanto na espécie denominada "autogestão na produção da moradia" o que se busca é o protagonismo dessas famílias na gestão do processo de produção dos empreendimentos, sem finalidade de lucro, representadas por associações ou cooperativas habitacionais genuínas e a partir de relações contratuais estabelecidas com o Estado.

Os programas de produção autogestionária da moradia tiveram muito inferior aos programas de produção executados por meio da contratação de empesas construtoras, mas isso não significa que sejam irrelevantes.

\subsection{Autogestão no Minha Casa Minha Vida - Entidades}

O programa Minha Casa Minha Vida foi criado pela Medida Provisória oㅡ 459, de 25 de março de 2009 destinado a financiar em condições especiais a produção habitacional de interesse social e de mercado para renda média, criado no governo Lula com uma característica dúplice: viabilizar a produção de moradias e estimular o mercado da construção civil, numa de combate à crise e à instabilidade política e econômica - bem como aos seus impactos negativos sobre os níveis de emprego decorrentes da crise financeira a que o país estava submetido ${ }^{50}$.

Noutra perspectiva, os movimentos de moradia sustentaram um projeto alternativo, mais articulado com o conjunto de medidas pactuadas no Plano Nacional de Habitação e construídas coletivamente nas discussões do Fórum Nacional de Reforma Urbana.

Antes de apresentar as propostas do Fórum, descrevo em linhas gerais suas considerações iniciais sobre o plano. Em linhas gerais, o FNRU defende um conjunto de medidas articuladas, que aproveite os imóveis públicos vazios e subutilizados, aplicando a concessão de uso especial para fins de moradia; que

\footnotetext{
${ }^{50} \mathrm{O}$ programa foi anunciado com meta de construção de 1 milhão de moradias, face ao déficit habitacional brasileiro o que também possuía uma grande apelo político.
} 
priorize, além da produção social da moradia, assistida tecnicamente com base na lei federal 11.888/08, também a alocação de recursos para a construção das casas nas áreas centrais e infra-estruturadas, com serviços de saúde, educação, transporte e saneamento básico, revertendo a tendência atual de concentrar os empreendimentos de construção de moradia popular em áreas distantes e sem infra-estrutura urbana, provocando o aumento da segregação. Que também, paralelamente à construção das novas moradias, seja garantida a implementação da política de regulação do uso do solo, de forma a coibir a especulação imobiliária. Que haja garantia de controle social na utilização dos recursos e redução da burocracia na implementação dos empreendimentos habitacionais e rapidez nos procedimentos de contratação, início e liberação das obras.

$\mathrm{Na}$ oportunidade, o FNRU manifestou por meio de carta aberta apresentando as seguintes reinvindicações:

- Prioridade para a construção de moradias em sintonia com a política nacional de desenvolvimento urbano, garantindo que a construção de 1 milhão de novas moradias esteja articulada com o Plano Nacional de Habitação ( PLANHAB) que está sendo finalizado no âmbito no Conselho Nacional das Cidades em conjunto com o Ministério das Cidades;

- Prioridade para as famílias com renda familiar de 0 a 3 salários mínimos, que é a faixa onde se concentra $90 \%$ do déficit habitacional, com a garantia de subsídios adequados para essa faixa de renda, visto que estas famílias são aquelas que apresentam maiores necessidades e maiores dificuldades em acessar os programas de moradia. Uma dessas medidas deve ser o estabelecimento de um Fundo Garantidor para facilitar o acesso ao financiamento e arcar com as prestações dos mutuários que porventura fiquem desempregados;

- Que o programa adote mecanismos de sustentabilidade ambiental, como o uso de madeira certificada, de energia solar, de racionalização do uso da água, e de coleta, tratamento e destinação final dos esgotos de forma tecnicamente correta;

- Prioridade para a Produção Social da Moradia, assistida tecnicamente com base na lei federal 11.888/08; 
- Prioridade na alocação de recursos para os grandes centros urbanos, nas áreas centrais e infra- estruturadas, com parâmetros diferenciados de financiamento, de modo que os setores privado e público priorizem a implantação de moradias em locais com serviços de saúde, educação, transporte e saneamento básico, revertendo a tendência atual de concentrar os empreendimentos de moradia popular em áreas distantes e sem infraestrutura urbana e social, o que provoca o aumento da segregação e da violência urbana;

- Que as concessionárias de serviços públicos de saneamento e energia sejam obrigadas a implantar a infra-estrutura de abastecimento de água, esgoto e energia nos programas de habitação popular, tendo em vista que estes investimentos serão amortizados pela cobrança da prestação do respectivo serviço aos futuros moradores. É importante ressaltar que este investimento, que representa em média $6 \%$ do custo da unidade habitacional, é atualmente bancado pelos empreendedores (que repassam aos futuros moradores) ou pelo Poder Público Municipal. Neste sentido, também é fundamental regulamentar a lei nacional de saneamento ambiental (lei 11.445/07), de forma a viabilizar a universalização dos serviços de saneamento e o controle social sobre estes.

- Que paralelamente à construção das novas moradias, seja garantida a implementação da política de regulação do uso do solo e dos instrumentos previstos no Estatuto da Cidade, de forma a coibir a especulação imobiliária e pressionar pela ocupação dos vazios urbanos;

- Que os recursos sejam alocados no Fundo Nacional de Habitação de Interesse Social, de forma a garantir que sua utilização seja realizada com controle social, ou seja, com a participação da sociedade organizada. Além disso, deve ser garantida a alocação de mais recursos ao programa federal vinculado à Ação de Apoio à produção social da moradia e ao Programa Crédito Solidário, de forma a impulsionar as ações vinculadas aos grupos autogestionários, organizados em associações comunitárias e cooperativas habitacionais.

- Redução da burocracia na implementação dos empreendimentos habitacionais e maior rapidez nos procedimentos de contratação, início e 
liberação das obras;

- Desapropriação de terras e imóveis com recursos federais;

- Promover o acesso a terra urbanizada para as populações de baixa renda, fomentando programas e processos de regularização fundiária, especialmente aqueles em áreas já reconhecidas como ZEIS pelos Planos Diretores Municipais, viabilizando o acesso aos recursos para a melhoria da infra-estrutura habitacional e regularização jurídica dos assentamentos.

- Controle social em todas as fases da implantação das medidas, de modo a buscar evitar o desperdício, o desvio ou a apropriação dos recursos sem nenhum controle pelas empreiteiras, garantindo o início e a conclusão das obras.

Ou seja, desde sempre esteve colocada como pano de fundo desse processo de construção política uma disputa entre os atores, visando dar sentidos diversos à política habitacional do país. Sem mecanismos efetivos de mediação, esta disputa foi tratada por meio da criação de diversas modalidades distintas, com importância e financiamentos muitos diferenciados, para cada um desses agentes.

O contraponto ao modo tradicional poderia ser representado pela proposta de produção autogestionária de moradia que ficou regulada com a criação do MCMV-E. No entanto, como revela LAGO (2015, ob. cit. pg. 11):

A partir de 2003, o quadro de contradições no campo da política urbana se amplia em função da crescente alocação, pelo governo federal petista, de recursos públicos para formas associativas de produção habitacional e, dialeticamente, da crescente absorção dessas experiências coletivas pela racionalidade dominante da valorização imobiliária. Nos últimos dez anos, já foram implantados três programas de financiamento para empreendimentos habitacionais autogeridos por associações comunitárias e cooperativas em todo o país ${ }^{15}$. No entanto, nenhum dos programas pode ser considerado como ação prioritária, e sim como respostas tímidas do poder público às reivindicações dos movimentos nacionais de moradia $^{16}$.

$\ldots$

$\mathrm{Na}$ realidade, a conquista pelos movimentos sociais de recursos públicos para a produção autogestionária da moradia não está sendo acompanhada por uma significativa alteração na correlação e forças que define as normas e princípios que regulam o uso desses recursos. Podemos destacar como exemplo a inoperância dos governos locais na redistribuição da terra urbanizada e ociosa, 
principal recurso para a democratização do acesso à cidade. Não faltam instrumentos legais nos marcos regulatórios nacionais e locais, tais como desapropriação, doação ou concessão de terras, para a reversão do domínio territorial pelas classes dominantes.

Mas, ao revés, as análises contemporâneas dão conta de que a produção ou equivaleu-se à produção realizada de forma tradicional por empresas ou, mesmo nos casos em que se obteve melhor qualidade ou foi subjugada e tragada no contexto de desregulamentação e financeirização da economia. Assim, ao invés de fortalecida, a proposta autogestionária - naqueles elementos que a caracterizavam historicamente - teria saído enfraquecida. Para Risek, (2014, p.244):

"Importante notar aqui que a modalidade Entidades teria sido
responsável por um suposto contraponto ao incentivo e incremento
das soluções de mercado. Pelo menos num primeiro momento, a
modalidade entidades parecia contemplar o movimento social de
moradia, em sua dinâmica multifacetada (regionalmente e entre
inspirações político ideológicas diversas) com uma política pública de
âmbito nacional. Com o avanço dos empreendimentos e o desenrolar
dos processos em tela, porém, essa legitimidade e essa esperança
se desvaneceram quase por completo".

É possível identificar uma certa convivência de projetos cujas características se aproximam dos projetos gestados na década de 80 , onde são perceptíveis processos de mobilização anteriores à conquista do projeto habitacional, participação dos beneficiários finais na discussão do projeto, no gerenciamento da obra e, muitas vezes, no trabalho mutirante necessário à execução das obras, e, finalmente na aplicação de programas de gestão da pós ocupação com processos em que, ao menos algum desses elementos, foram terceirizados para organizações estranhas à entidade promotora do empreendimento habitacional. Em suma: mesmo no âmbito da produção associativa, verificou-se uma convivência entre produção não mercantil autogestionária e produção mercantil que pode ser qualificada, no máximo, como cogestão da produção habitacional.

$\mathrm{Na}$ realidade, mesmo no "Entidades" é possível verificar um conjunto de contradições próprios da tentativa de viabilizar a mudança de paradigma de forma incremental, num contexto adverso e movido por forças e interesses conjunturais muito específicos.

Contradição entre o discurso direito à cidade que defender a boa localização e a localização periférica dos conjuntos já apontada em vários estudos. 
Contradição entre os valores políticos originais dos processos autogestionários: participação dos futuros moradores, autogestão da produção, ajuda mútua, e a adaptação aos novos programas em que a participação é tênue a autogestão e a ajuda mútua tornam-se dispensáveis, a propriedade da terra é aquela tradicionalmente utilizada nas relações mercantis e a participação e o trabalho social limita-se à aplicação burocrática de métodos tradicionais de educação desvinculados da ideia básica de emancipação.

Contradição da formatação dos programas entre a forma original baseada no tripé: poder público consorciado com as assessorias técnicas de caráter interdisciplinar e não lucrativo e com as entidades representativas dos futuros moradores e a forma adotada majoritariamente no programa: Poder público consorciado com entidades representativas desvirtuadas de suas finalidades originais para "representar" uma demanda indeterminada, muitas vezes reunida apenas e tão somente para a obtenção de moradia e cuja obras seriam efetivamente controladas por empresas construtoras, ausentes os mecanismos de debate democrático de projeto e de controle social do processo.

As contradições verificadas na análise dos documentos das entidades, na avaliação crítica da legislação e nas entrevistas com os diversos atores (lideranças sociais, profissionais das assessorias técnicas ou das empresas, gestores públicos, pesquisadores do tema) já tornou evidentes tais efeitos, mas a pesquisa, para além da sistematização de tais questões, também objetiva investigar as motivações que levaram às decisões especificamente consideradas. Um primeiro passo será avaliar no contexto sócio econômicos em que se desenvolveram as decisões que afetaram tanto os poderes públicos como as cooperativas e associações.

Após uma longa e sentida ausência em termos de iniciativa governamental, a política pública de provisão de habitação de interesse social foi hegemonizada na última década pelas ações do programa Minha Casa Minha Vida. O programa federal nublou quaisquer outras iniciativas dos demais entes federativos em razão de sua magnitude.

Entretanto, de forma geral, note-se o programa repete a fragilidade dos programas pioneiros na medida em que padece de uma institucionalização, pois está estruturado basicamente a partir de decretos, instruções normativas, portarias e resoluções administrativas do poder executivo, passível, como ocorre de fato, a sucessivas alterações, interrupções e constrangimentos. Nessa condição, persistirá 
certa insegurança jurídica aos agentes interessados no desenvolvimento do programa.

Em princípio, o marco legal utilizado para viabilizar os programas augestionários de moradia é insuficiente e precário. É ineficiente porque os conceitos essenciais, os princípios e os critérios operacionais não estão positivados em Lei no sentido estrito. É precário porque, na realidade, as regras existentes estão parcialmente veiculadas na forma que os juristas denominam Regulamento, ou seja, em Decretos, Resoluções, Portarias e Instruções Normativas. Para Bandeira de Mello (2004, p.337):

"O Regulamento não pode ser instrumento para regular matéria que, por ser legislativa, é insuscetível de delegação, menos ainda poderão fazê-los atos de estirpe inferior, quais instruções, portarias e resoluções".

Subdivido em modalidades, o programa se desenvolveu em três faixas de renda, mas paulatinamente, ao longo dos anos, foi ampliando a aplicação de recursos nas faixas de menor renda em relação ao que foi aplicado nas faixas de maior renda. Ou seja, desse ponto de vista, nada a considerar: finalmente, um programa habitacional, levou em consideração um dos principais defeitos das nossas políticas habitacionais. Foi um programa destinado à produzir habitação para os que dela precisam. O quadro abaixo permite constatar o que está enunciado:

O Programa Minha Casa Minha Vida foi desenvolvido em três fases. A primeira delas foi lançada em 25 de março de 2009, durante o último biênio da segunda gestão do Presidente Luís Inácio Lula da Silva e teve duração de quase dois anos, até o final do seu mandato. A segunda fase correspondeu ao primeiro mandato da presidenta Dilma Roussef, de 2010 a 2014, com duração de 4 anos. A terceira etapa iniciou-se em $2015^{51}$ no início do segundo mandato da presidenta Dilma Roussef e, formalmente, segue existindo até o final de 2019. No entanto, é notório que o programa perdeu seus investimentos e prioridade após o processo de impeachment iniciado em maio de 2016 e concluído em 2018. Em 2019, não houve contratações na Faixa 1 do programa, apenas nas Faixas 2 e 3, com recursos do

\footnotetext{
${ }^{51}$ Apesar das regras da terceira fase do programa terem sido formalizadas apenas em 30 de março de 2016, o Ministério das Cidades considera as contratações de 2015 como parte dessa fase (Caixa, 2016).
} 
FGTS. Esta dissertação abordará a produção contratada de 2009 até o final de 2016 e considerará esses números para as suas análises.

\begin{tabular}{|c|c|c|}
\hline MCMV 1 & MCMV 2 & MCMV 3 \\
\hline 2009 a 2010 & 2011 a 2014 & 2015 a 2016 \\
\hline
\end{tabular}

Fonte: Caixa, 2019

O chamado Programa Minha Casa Minha Vida contava com três faixas de renda. Durante as três fases do programa, os limites de renda foram sendo atualizados, sem, no entanto, serem indexados pelo salário mínimo, conforme anunciado em seu lançamento. A Faixa 1 era composta de 4 modalidades, todas financiadas com recursos exclusivamente do Orçamento Geral da União. As Faixas 2 e 3, contavam com financiamento oneroso do FGTS a taxas reduzidas e a Faixa 2 tinha um desconto ou subsídio na aquisição do imóvel. Esse subsídio tinha como fonte principal o FGTS e também contava com recursos do OGU.

Tabela 2 - Faixas de renda atendidas em cada Fase do PMCMV

\begin{tabular}{c|l|l|l|l}
\hline $\begin{array}{c}\text { Faixa de } \\
\text { renda } \\
\mathbf{( R \$ )}\end{array}$ & \multicolumn{1}{|c|}{ MCMV 1 } & \multicolumn{1}{|c|}{ MCMV 2 } & \multicolumn{1}{|c}{ MCMV 3 } & \multicolumn{1}{c}{$\begin{array}{c}\text { MCMV 3 } \\
\text { (atualização em } \\
\text { 2018) }\end{array}$} \\
\hline 1 & Até $1.395,00$ & Até R\$ $1.600,00$ & Até $1.800,00$ & Até $1.800,00$ \\
\hline 1,5 & não se aplica & não se aplica & Até $2.350,00$ & Até $2.600,00$ \\
\hline 2 & $1.396,00$ a $2.790,00$ & $1.601,00$ a 3.275,00 & $\begin{array}{l}2.351,00 \mathrm{a} \\
3.600,00\end{array}$ & $\begin{array}{c}2.601,00 \mathrm{a} \\
4.000,00\end{array}$ \\
\hline 3 & $2.791,00$ a $4.650,00$ & $3.276,00$ a $5.000,00$ & $\begin{array}{l}3.601,00 \mathrm{a} \\
6.500,00\end{array}$ & $\begin{array}{c}4.001,00 \mathrm{a} \\
7.000,00\end{array}$ \\
\hline
\end{tabular}

Fonte: Caixa Econômica Federal, Base 31-12-2016

No MCMV 3 foi incluída a popularmente chamada "Faixa 1 e meio" que tinha regras semelhantes ao Faixa 2, no entanto, com maior subsidio. Para efeito da 
computação dos números do programa, a Caixa incluiu as unidades do faixa 1 e meio na faixa 2.

Tabela 3 - Número de Unidades habitacionais contratadas em cada fase do programa, por Faixa de Renda

\begin{tabular}{l|r|r|r|r}
\hline & \multicolumn{1}{c|}{ MCMV 1 } & \multicolumn{1}{c|}{ MCMV 2 } & \multicolumn{1}{c}{ MCMV 3 } & \multicolumn{1}{c}{ TOTAL } \\
\hline FAIXA 1 & 482.741 & 1.226 .586 & 53.748 & 1.763 .075 \\
\hline FAIXA 2 & 375.764 & 1.216 .341 & 626.812 & 2.218 .917 \\
\hline FAIXA 3 & 146.623 & 307.054 & 108.761 & 562.438 \\
\hline TOTAL & 1.005 .128 & 2.749 .981 & 789.321 & 4.544 .430 \\
\hline
\end{tabular}

Fonte: Caixa Econômica Federal, Base 31-12-2016

\section{Gráfico 1 - Participação percentual de cada faixa de renda do programa, em cada fase}

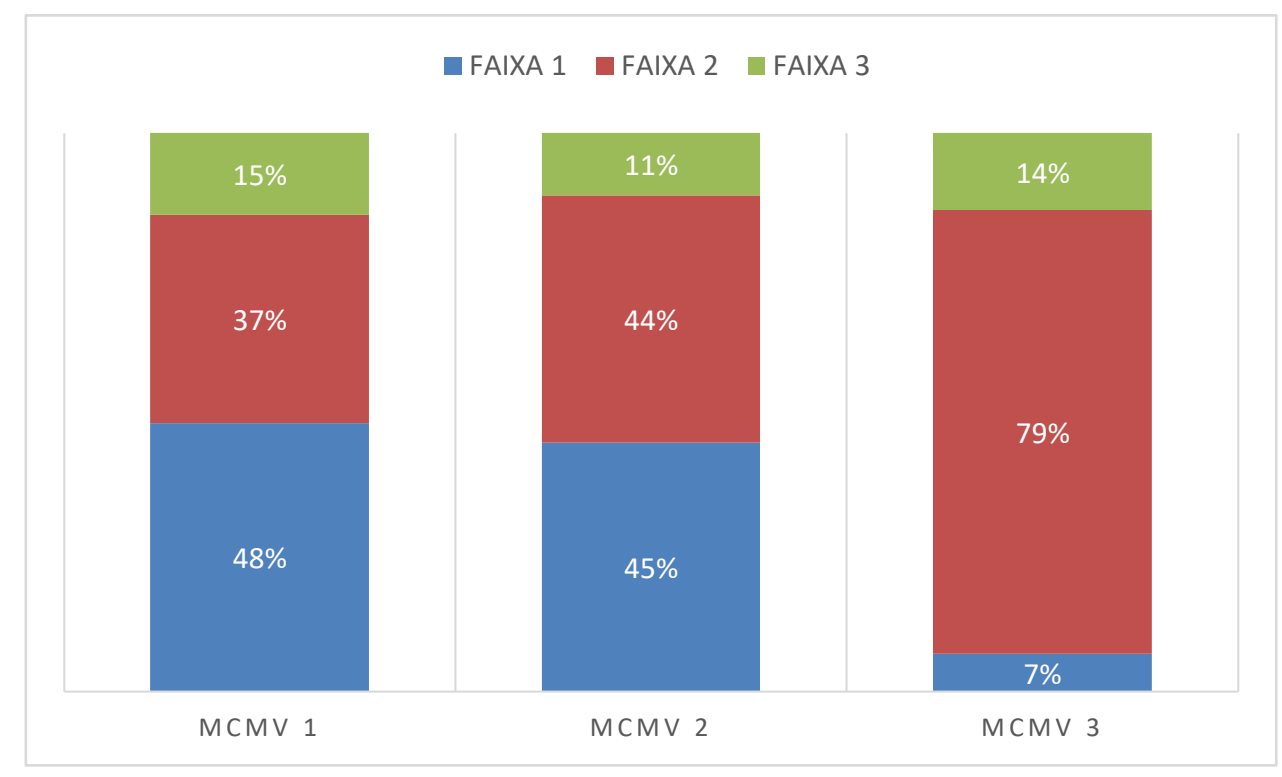

Fonte: Caixa Econômica Federal, Base 31-12-2016

Desses dados, é possível verificar algumas questões:

A Faixa 1, que dependia exclusivamente de recursos do Orçamento Geral da União foi severamente reduzida na terceira fase do programa, época que coincidiu com a crise econômica ocorrida no país. Nesse cenário, não só os números totais absolutos caíram drasticamente (de 687.495 em média por ano, no MCMV 2 para 394.661 em média por ano, no MCMV 3), mas essa queda se concentrou na Faixa 1 
(de 306.647 em média por ano, no MCMV 2 para 26.874 em média por ano, no MCMV 3).

As Faixas 2 e 3, que contavam como principal fonte de recursos o FGTS, sofreu bem menos os efeitos da crise. Especialmente a faixa 2 manteve medias anuais muito semelhantes no MCMV 2 e 3 (304.085 e 313.406, respectivamente). A perenidade dessa fonte de recursos, naquele momento, apesar de contar com algum subsídio do OGU, pode ser apontada como causa desse resultado.

É importante destacar que esses dados refletem a quantidade de unidades contratadas no Programa e não os recursos investidos. Via de regra, os valores de cada unidade habitacional na Faixa 1 são bem menores daqueles das Faixas 2 e 3. E mesmo na Faixa 1, os valores do FAR e FDS são muito menores que os valores das unidades do Rural e Sub 50.

Apenas a título de ilustração, já que este trabalho compreende os períodos de 2009 a 2016, verificamos que, durante os 31 meses do mandato do presidente Michel Temer, o perfil de contratação foi bastante semelhante àquele observado nos primeiros anos do MCMV 3, embora tenha crescido a contratação na faixa 1, houve expressiva participação da Faixa 2.

Tabela 4 - Número de Unidades habitacionais contratadas em cada modalidade da faixa 1, por fase do programa, até 2018

\begin{tabular}{l|r|r|r|r|r}
\hline & MCMV 1 & MCMV 2 & $\begin{array}{r}\text { MCMV 3 } \\
\text { (Até 2016) }\end{array}$ & $\begin{array}{r}\text { MCMV 3 } \\
\text { (Pós 2016) }\end{array}$ & \multicolumn{1}{c}{ Totais } \\
\hline FAIXA 1 & 482.741 & 1.226 .586 & 53.748 & 133.259 & 1.896 .334 \\
\hline FAIXA 2 & 375.764 & 1.216 .341 & 626.812 & 795.399 & 3.014 .316 \\
\hline FAIXA 3 & 146.623 & 307.054 & 108.761 & 93.925 & 656.363 \\
\hline TOTAL & $\mathbf{1 . 0 0 5 . 1 2 8}$ & $\mathbf{2 . 7 4 9 . 9 8 1}$ & $\mathbf{7 8 9 . 3 2 1}$ & $\mathbf{1 . 0 2 2 . 5 8 3}$ & $\mathbf{5 . 5 6 7 . 0 1 3}$ \\
\hline
\end{tabular}

Fonte: Caixa Econômica Federal, Base 31-12-2018 
Gráfico 2 - Participação percentual de cada faixa de renda do programa, até 2018

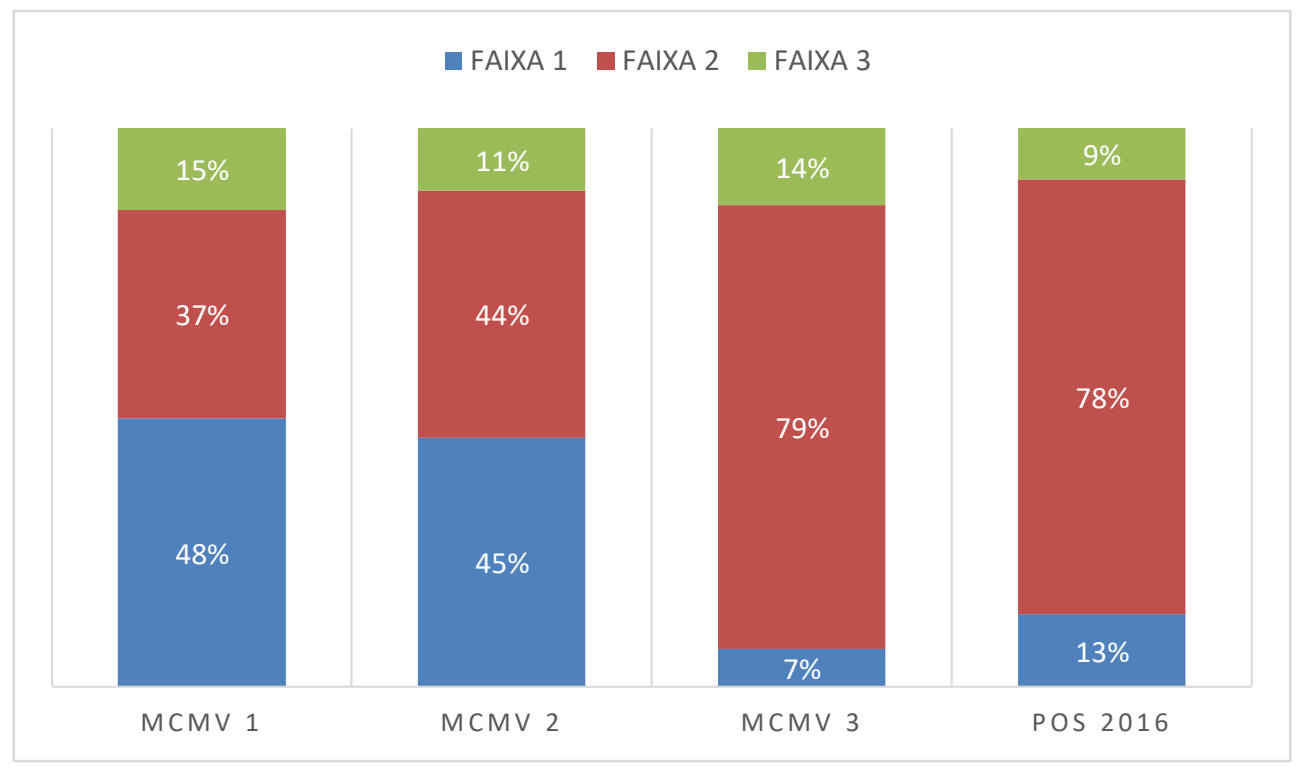

Fonte: Caixa Econômica Federal, Base 31-12-2018

\subsection{Contratações na Faixa 1 do PMCMV}

A Faixa 1 do Programa Minha Casa Minha Vida foi destinada ás famílias de mais baixa renda (ver Tabela 2) e contou com mecanismos para o atendimento de famílias excluídas pelas demais formas de financiamento de mercado e mesmo das demais políticas habitacionais. Os principais mecanismos para esse acesso foram o enorme subsídio concedido às famílias ${ }^{52}$, a não exigência de comprovação de renda, que poderia ser autodeclarada, a possibilidade de atendimento de famílias cujos membros tinham restrição cadastral no Sistema de Proteção ao Crédito (SPC) e nos estabelecimentos bancários (SERASA) e a não exigência de poupança prévia ou entrada para acesso às moradias. Essas medidas só puderam ser adotadas devido a que todas as modalidades da Faixa 1 serem custeadas exclusivamente por recursos não onerosos advindos do Orçamento Geral da União.

A Faixa 1 do PMCMV constituiu-se de 4 modalidades operacionais:

- MCMV FAR - Com contratação diretamente com as empresas, que eram responsáveis pela viabilização da terra, licenciamento, construção e legalização das

\footnotetext{
${ }^{52}$ Em alguns momentos do programa, a prestação mínima da Faixa 1 foi de $\mathrm{R} \$ 50,00$ por 120 meses, fazendo com o que o teto do subsídio pudesse chegar a $92 \%$ da unidade habitacional, em uma moradia com valor de investimento do FAR ou FDS de R\$96.000,00.
} 
unidades que eram destinadas à demanda selecionada pelos municípios. O recursos do OGU eram repassados ao Fundo de Arrendamento Residencial, que era responsável pela transferência de recursos ao empreendimento.

- MCMV Entidades - Com contratação diretamente com as entidades organizadoras, que eram responsáveis pela constituição do grupo de famílias, viabilização da terra, licenciamento, construção, legalização das unidades. O recursos do OGU eram repassados ao Fundo de Desenvolvimento Social (FDS), que era responsável pela transferência de recursos ao empreendimento.

- MCMV Rural ou Programa Nacional de Habitação Rural (PNHR) - Com contratação diretamente com as entidades organizadoras ou prefeituras, que eram responsáveis pela constituição do grupo de famílias, viabilização da terra e construção das unidades. O recursos do OGU eram repassados diretamente ao empreendimento.

- Oferta Pública de Recursos ou Sub 50 - Contratação de instituições financeiras e a agentes financeiros do Sistema Financeiro da Habitação (SFH), de modo a operacionalizar a subvenção econômica do programa a beneficiários em municípios com população de até $50 \mathrm{mil}$ habitantes. Esta modalidade foi interrompida durante a fase 2 do programa.

A Caixa atuou como agente operador e financeiro das três primeiras modalidades (FAR, FDS e Rural) e o Banco do Brasil atuou como agente financeiro no FAR e Rural.

Em todas as modalidades, era facultado aos municípios e aos estados participarem com contrapartidas não onerosas, que poderiam ser em terrenos, obras complementares de infraestrutura ou recursos financeiros.

Ao longo das 3 fases do programa, foram contratadas 1.763.075 unidades habitacionais nessa faixa, com a seguinte distribuição por modalidade: 
Tabela 5 - Número de unidades habitacionais contratadas nas modalidades da faixa1, em cada fase

\begin{tabular}{l|r|r|r|c}
\hline & MCMV 1 & MCMV 2 & MCMV 3 & Totais \\
\hline MCMV FAR & 404.128 & 917.815 & 7.012 & 1.328 .955 \\
\hline MCMV RURAL & 6.817 & 159.839 & 28.322 & 194.978 \\
\hline MCMV Entidades & 8.024 & 45.839 & 18.414 & 72.277 \\
\hline SUB 50 & 63.772 & 103.093 & - & 166.865 \\
\hline FAIXA 1 & $\mathbf{4 8 2 . 7 4 1}$ & $\mathbf{1 . 2 2 6 . 5 8 6}$ & $\mathbf{5 3 . 7 4 8}$ & $\mathbf{1 . 7 6 3 . 0 7 5}$ \\
\hline
\end{tabular}

Fonte: Caixa Econômica Federal, Base 31-12-2016

Como demonstrado no gráfico abaixo, a modalidade destinada à contratação com as empresas construtoras (MCMV FAR) foi a modalidade principal do Programa, com $75 \%$ das unidades habitacionais contratadas.

Destaque deve ser dado à contratação da modalidade MCMV Rural ou Programa Nacional de Habitação Rural (PNHR), com cerca de 10\% das contratações e mais de 190 mil unidades habitacionais e que foi operado, em sua maior parte, por entidades ligadas ao movimento da agricultura familiar, trabalhadores rurais e assentados da reforma agrária. A habitação rural era um item antigo da pauta de reivindicações de diversos movimentos camponeses ${ }^{53}$ e se concretizou na criação do PNHR. Antes dele, parte dessa demanda foi atendida por programas do Instituto Nacional de Colonização e Reforma Agrária (INCRA), dentro dos recursos de instalação de novos assentamentos ou ainda no Programa Crédito Solidário (2004 a 2008).

\footnotetext{
53 Movimentos sociais, tais como Confederação Nacional dos Trabalhadores na Agricultura CONTAG, Confederação Nacional dos Trabalhadores Trabalhadoras na Agricultura Familiar do Brasil - CONTRAF / FETRAF-BRASIL, Movimento Camponês Popular - MCP, Movimento dos Atingidos por Barragens - MAB, Movimento dos Pequenos Agricultores - MPA, Coordenação Nacional de Articulação das Comunidades Negras Rurais Quilombolas - CONAQ e Movimento dos Trabalhadores Rurais Sem-Terra, integraram a Mesa da Habitação Rural com interlocução permanente com o governo federal.
} 
Gráfico 3 - Participação percentual das modalidades da faixa1

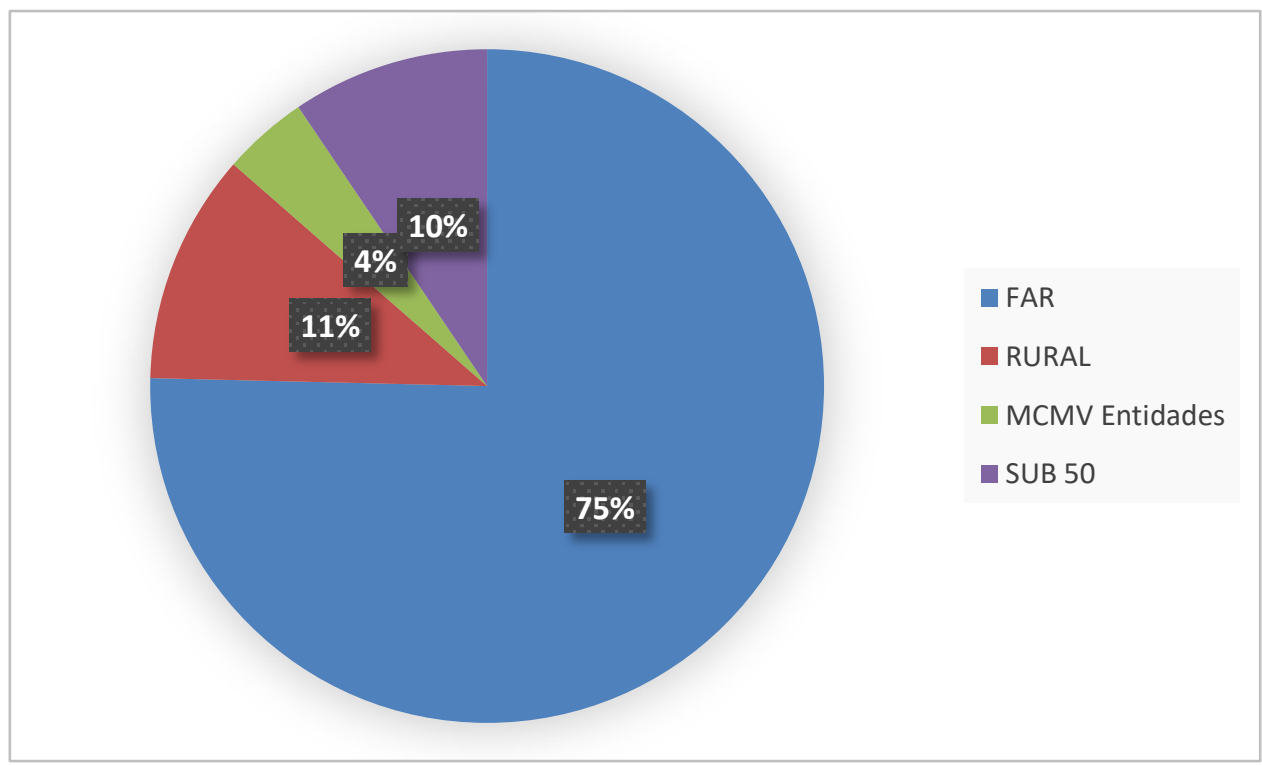

Fonte: Caixa Econômica Federal, Base 31-12-2016

O MCMV Entidades somou, ao longo do período analisado, o total de 72.277 unidades habitacionais contratadas, totalizando $4 \%$ de toda a Faixa 1 do PMCMV. $O$ ritmo de contratação do MCMV Entidades foi bastante irregular, conforme vemos no Gráfico 4:

Gráfico 4 - Evolução da contratação do MCMV-E, por ano (unidades contratadas)

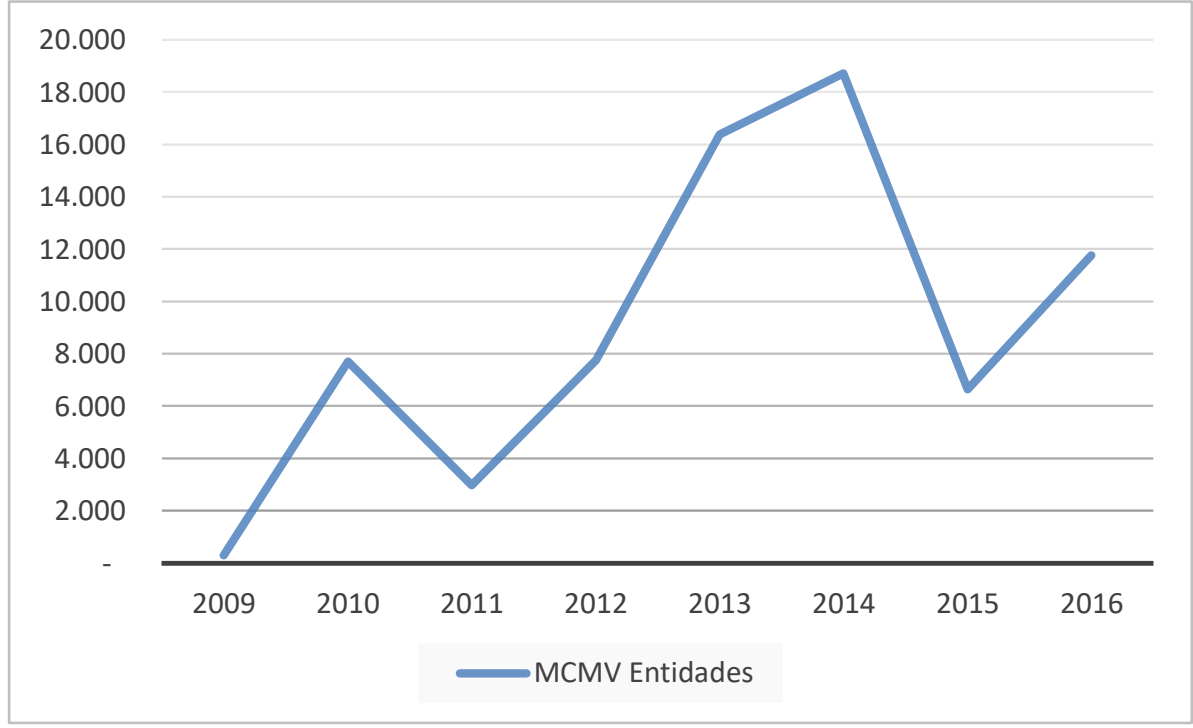

Fonte: Caixa Econômica Federal, Base 31-12-2016 
É possível perceber uma "curva de aprendizado" na atuação do programa, que envolveu tanto as Entidades Organizadoras quanto o poder público. Nos primeiros anos do programa, havia mais recursos disponíveis do que propostas aptas para contratação, fazendo que "sobrassem" recursos na modalidade, que eram remanejados para outras modalidades, especialmente para o FAR. Nesse período, o programa não contava com critérios para a hierarquização das propostas, pois todas aquelas que venciam as diversas etapas de análise no Agente Financeiro eram selecionadas pelo Ministério das Cidades.

A partir de 2015, esse quadro se reverte. Com mais propostas aprovadas no Agente Financeiro do que recursos disponíveis para contratação, a Secretaria Nacional de Habitação passa a fazer processos de hierarquização das propostas. Nesse momento, o MCMV Entidades sofre os mesmos efeitos da redução de recursos orçamentários sofridos por todas as modalidades da faixa 1 do Programa e reduz sensivelmente as suas contratações.

Após o processo de impeachment que afastou a presidenta Dilma Roussef até o final de 2016, não houve nenhuma nova seleção ou contratação. As portarias 173 e 186/2016, que pré-selecionavam empreendimentos para futura contratação no programa, foram canceladas pelo Ministro Bruno Araújo, indicado pelo presidente Michel Temer imediatamente após a sua posse, por meio da Portaria 186.

\section{5 - Implicações políticas ${ }^{54}$ e jurídicas nos processos de produção autogestionária da moradia.}

No chamado Estado Democrático, a ação de Estado se manifesta por meio da execução de políticas públicas, que como já dito, podem ser entendidas como um conjunto articulado de ações governamentais.

Tais ações governamentais são caracterizadas por determinadas intencionalidades, que na garantia do interesse público, devem ser construídas com a participação direta dos atores interessados. Chrispino $(2018$, p. 30) defende que o estudo das políticas públicas deve considerar o plano das ideias, quando se

\footnotetext{
${ }^{54}$ O texto considera como implicações políticas conforme seu significado clássico moderno sintetizado por BOBBIO (1995, p. 954) para quem na interpretação do conceito de política devem ser considerados os meios pelos quais um determinado grupo social busca a obtenção de determinadas vantagens no contexto de um contrato social que legitima o monopólio da coerção do Estado.
} 
relaciona com a concepção de mundo que orienta a administração e como ação de governo que se materializa nas normas juridicamente colocadas. O Autor ressalta a importância de questionar as intencionalidades por detrás dos processos de formulação, inclusive para desvendar eventuais silêncios ou não decisões que poderiam dar rumos distintos aos processos de formulação e execução.

Como já dito no capítulo II, o MCMV-E responde à pressão realizada por movimentos de moradia pela execução, no âmbito do governo federal, de um programa habitacional capaz de dar conta de desafios colocados por 30 anos de experiências locais de autogestão no país e que podem ser relacionadas aos abaixo relacionados:

\subsubsection{Autogestão e os princípios constitucionais.}

A Constituição relacionou um conjunto de direitos individuais esclarecendo que a sua proteção se estende aos brasileiros e aos estrangeiros residentes no País, sem distinção aparente entre pessoas físicas ou pessoas jurídicas. Para a discussão sobre a efetividade dos regramentos dos programas habitacionais é importante reter a noção de que sua interpretação deve estar pautada na concepção de valores como igualdade substancial (isonomia), da legalidade, impessoalidade, moralidade, publicidade e eficiência.

A isonomia pressupõe o tratamento uniforme entre todas as pessoas. Não se trata, como se vê, de um tratamento igual perante o direito, mas de uma igualdade real, materialmente verificável. A ideia tal como a reconhecemos na atualidade nasce no processo da revolução francesa. Tratava-se de abolir a sociedade estamental então vigorante.

A igualdade se manifesta quanto todo e qualquer cidadão não ser desigualado pela lei senão em consonância com os critérios relacionados implícita ou explicitamente presentes na constituição federal.

O princípio legalidade diz que que ninguém é obrigado a fazer ou deixar de fazer algo senão em virtude de lei. A sua significação é dúplice. De um lado representa o marco avançado do Estado de Direito, que procura jugular os comportamentos, quer individuais, quer dos órgãos estatais, às normas jurídicas das quais as leis são a suprema expressão. Nesse sentido, o princípio da legalidade é 
de transcendental importância para vincar as distinções entre o Estado constitucional e o absolutista.

De outro lado, o princípio da legalidade garante o particular contra os possíveis desmandos do Executivo e do próprio Judiciário. Instaura-se, em consequência, uma mecânica entre os Poderes do Estado, da qual resulta ser lícito apenas a um deles, qual seja o Legislativo, obrigar aos particulares.

A impessoalidade está intimamente ligada a outros princípios, tais como o da finalidade, o da isonomia e mesmo o da legalidade. De fato, a lei tem de ser aplicada de molde a não levar em conta critérios nela não inseridos. Toda vez que o administrador pratica algum entorse na legislação para abranger uma situação por ela não colhida ou para deixar de abarcar uma outra naturalmente inclusa no modelo legal, a Administração está-se desviando da trilha da legalidade. Essa derrapagem nem sempre é ostensiva.

O princípio da moralidade como reitor da atuação da Administração Pública. Não que esse princípio fosse absolutamente desconhecido do nosso direito administrativo aumento do controle jurisdicional sobre a atividade administrativa. Aliás, a concretização desse princípio dá-se em diversos pontos da Constituição. $O$ $\S 4.0$ do art. 37 postula que os atos de improbidade administrativa importarão a suspensão dos direitos políticos, a perda da função pública, a indisponibilidade dos bens e o ressarcimento ao erário, na forma e gradação previstas em lei, sem prejuízo da ação penal cabível. Figura como crime de responsabilidade o ato do Presidente da República que atente contra a probidade na administração, consoante $\mathrm{o}$ art. 85, V. E, ainda, nos termos do art. 5.0 LXXIII, consigna a Constituição que qualquer cidadão é parte legítima para propor ação popular que vise a anular ato lesivo à moralidade administrativa.

Finalmente, a Emenda Constitucional n. 19, de 4 de junho de 1998, deu nova redação ao caput do art. 37 da Constituição Federal, acrescentando mais um princípio, o da eficiência, aos quais a Administração Pública direta e indireta de qualquer dos Poderes da União, dos Estados, do Distrito Federal e dos Municípios deve obediência.

No entanto, embora a Emenda n. 19/98 ter consagrado o princípio da eficiência, este, certamente, já poderia ter sido extraído do nosso sistema, pois não seria razoável pensar em atividade da Administração Pública desempenhadas com 
ineficiência e sem o atingimento do seu objetivo maior que é o da realização do bem comum.

\subsubsection{Autogestão e a efetividade do direito à moradia.}

O Comentário Geral nº 4 do Comitê dos Direitos Econômicos, Sociais e Culturais da ONU, o direito à habitação digna se confunde com o conceito de moradia adequada e reúne um conjunto de elementos, nenhum deles passíveis de serem desconsiderados, mas que no processo autogestionário podem ser realçados: A segurança da posse, a disponibilidade de serviços, materiais, instalações e infraestrutura, a economicidade, a habitabilidade, a acessibilidade e a localização tendem a ser mais bem preservados em processos controlados pelos futuros moradores e onde a lucratividade do empreendimento não seja o valor fundamental.

A referência fundamental para a compreensão da extensão desse direito decorre do conteúdo da Declaração Universal dos Direitos Humanos, que inclui o

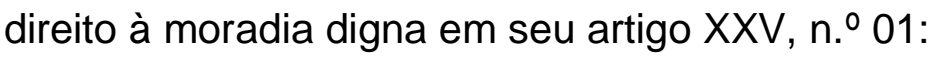

\footnotetext{
"Toda pessoa tem direito a um padrão de vida capaz de assegurar a si e a sua família saúde e bem estar, inclusive alimentação, vestuário, habitação, cuidados médicos e os serviços sociais indispensáveis, e o direito à segurança em caso de desemprego, doença, invalidez, viuvez, velhice ou outros casos de perda dos meios de subsistência fora de seu controle".
}

O Brasil incorporou este valor ao nosso sistema legislativo quando ratificou o Pacto Internacional de Direitos Civis e Políticos da ONU, por meio do Decreto 59, de 6 de julho de 1992, época da Conferência de Istambul. Esse Pacto em seu artigo 11, prevê a obrigação do Estado brasileiro de proteger e promover o direito à moradia digna nos seguintes termos:

"Art. 11. 1. Os Estados-partes no presente Pacto reconhecem o direito de toda pessoa a um nível de vida adequado para si próprio e sua família, inclusive à alimentação, vestimenta e moradia adequadas, assim como a uma melhoria contínua de suas condições de vida. Os Estados-partes tomarão medidas apropriadas para assegurar a consecução desse direito, reconhecendo nesse sentido, a importância essencial da cooperação internacional fundada no livre consentimento". 
Igualmente, por meio do Decreto 592, o país internalizou o Pacto Internacional de Direitos Civis e Políticos da ONU , que também prevê a proteção ao direito à moradia, no âmbito dos direitos de personalidade, ou seja, no âmbito propriamente privado.

Além disso, também dão suporte normativo de status constitucional ao direito à moradia digna, 0 artigo $\mathrm{V}$ da Convenção Internacional sobre a Eliminação de Todas as Formas de Discriminação Racial (1965), o artigo 14.2 (h) da Convenção sobre a Eliminação de todas as Formas de Discriminação contra a Mulher (1979) , o artigo 21, item 1 e 3 da Convenção sobre os Direitos da Criança (1989) .

No âmbito do Sistema Interamericano de Proteção aos Direitos Humanos, da OEA - Organização dos Estados Americanos, o Brasil entabulou compromissos de proteger e promover o direito à moradia digna nos seguintes, fazendo-os ingressar como norma constitucional no Direito interno brasileiro. Em especial, os retratados nos artigos 11, 24 e 26 da Convenção Americana de Direitos Humanos - Pacto de San José da Costa Rica.

Para evitar qualquer dúvida interpretativa acerca da natureza de direito humano fundamental - inclusive na forma de políticas públicas - editou-se a Emenda 64/2010, inserindo explicitamente a moradia no rol dos direitos sociais (artigo 6ㅇ).

Quanto à aplicabilidade das normas de direito internacional veiculadas nos tratados e convenções, SAULE JÚNIOR (2004, p. 87):

\footnotetext{
$(\ldots)$

"O posicionamento adotado em relação às normas dos tratados internacionais de direitos humanos, dos quais o Brasil seja parte, é o de que terão o mesmo valor jurídico das normas constitucionais e aplicação imediata em nosso ordenamento jurídico, resultando no entendimento de ser o Estado brasileiro incumbido, no campo dos direitos humanos, de respeitar e aplicar as normas destes tratados internacionais, destinadas à proteção do direito à moradia." $(\ldots)$
}

Especificamente, nos que diz respeito aos processos autogestionários, é possível relacionar alguns desdobramentos decorrentes de interpretação quanto à auto aplicabilidade.

Destaca-se aqui alguns aspectos fundamentais da autogestão na produção habitacional e de que forma estes foram tratados no Programa Minha Casa Minha 
Vida Entidades. Para isso, este trabalho considerará a primeira resolução e instrução normativa do programa, quando criado em 2009 e a última em vigor em 2016, o período estudado. O programa foi criado pela resolução $n^{0} 141$, de 10 de junho de 2009 do Conselho Curador do Fundo de Desenvolvimento Social e regulamentado pela instrução normativa (IN) no 36, de 15 de julho de 2009. Em 2016, vigorava a resolução $n^{\circ}$ 200, de 5 de agosto de 2014 e a instrução normativa $\mathrm{n}^{\circ} 39$, de 19 de dezembro de 2014 complementada pela IN $\mathrm{n} \cong 9$, de 28 de abril de 2016.

Destaca-se aqui alguns aspectos fundamentais da autogestão na produção habitacional e de que forma estes foram tratados no Programa Minha Casa Minha Vida Entidades. Para isso, este trabalho considerará a primeira resolução e instrução normativa do programa, quando criado em 2009 e a última em vigor em 2016, o período estudado. O programa foi criado pela resolução no 141 , de 10 de junho de 2009 do Conselho Curador do Fundo de Desenvolvimento Social e regulamentado pela instrução normativa (IN) no 36, de 15 de julho de 2009. Em 2016, vigorava a resolução n 200, de 5 de agosto de 2014 e a instrução normativa $\mathrm{n}^{\circ} 39$, de 19 de dezembro de 2014 complementada pela IN $\mathrm{n} \cong 9$, de 28 de abril de 2016.

Várias das alterações de normativo ocorridas durante esse período foram em decorrência da pressão dos movimentos sociais que atuavam no programa, apresentadas tanto no Conselho Nacional das Cidades quanto em atividades de pressão, como passeatas, caravanas e acampamentos.

\subsubsection{O caráter não mercantil da produção autogestionária.}

O MCMV-E foi criado exclusivamente para a participação da "população (...) organizada em cooperativas habitacionais ou mistas, associações e demais entidades privadas sem fins lucrativos ${ }^{55}$ ", num claro estímulo ao cooperativismo e associativismo, sendo vedada a participação de empresas como tomadora dos financiamentos ou promotora dos empreendimentos.

\footnotetext{
${ }^{55}$ Item 2 da Resolução CCFDS 141, 2009.
} 
Para participar do programa, a associação ou cooperativa deveria habilitar-se no Ministério das Cidades, demonstrando cumprir os requisitos do programa ${ }^{56}$. As exigências eram basicamente a sua constituição formal, demonstrada por atas e estatutos, e sua regularidade fiscal, por meio de certidões emitidas pelas fazendas dos três níveis de governo. Também era necessário demonstrar que a entidade estava constituída juridicamente há pelo menos 3 anos e ter, dentre os seus objetivos, a produção habitacional para seus associados.

Além disso, no mesmo procedimento, após cumprir os requisitos de qualificação a entidade era qualificada e recebia uma classificação de "A" a "D", que definia o número máximo de unidade que poderia contratar simultaneamente, com o mínimo de 50 e o máximo de 1.000 unidades. Essa análise era baseada em atributos e experiência da entidade, como atividades desenvolvidas com os seus associados, participação em instâncias formais como conselhos e conferências da área e experiência anterior em produção habitacional. Todos os requisitos deveriam ser comprovados por meio de documentos a serem entregues ao agente financeiro.

Nas primeiras portarias, estabelecia-se um prazo para a apresentação de documentos e publicação das entidades habilitadas. Posteriormente, o processo de habilitação ficou aberto de forma permanente.

A exigência de experiência para obter o grau de habilitação para construção de mais unidades levou à mudança, ao menos nas organizações do Estado de São Paulo, a mudarem uma de suas características importantes. Tanto nos programas municipais quanto no estadual, era parte da estratégia de organização formar uma associação específica somente com as famílias integrantes daquele empreendimento para celebrar contrato e gerir os recursos daquela obra. Nessa perspectiva, o movimento, de onde esse grupo se originava, era chamado "entidademãe", responsável por organizar a luta e travar as negociações, mas não tinha entre as suas atribuições, a gestão da produção habitacional: quem administrava era quem iria habitar. Ao exigir experiência prévia da personalidade jurídica que se habilitava, os movimentos ou entidades-mãe passaram a se habilitar eles próprios, deixando aberta a possibilidade que outros dirigentes, que não as famílias que iriam morar no conjunto, fossem responsáveis formais pelo contrato.

\footnotetext{
${ }^{56}$ Diversas portarias de habilitação de entidades sucederam-se durante o período estudado. A primeira delas foi a portaria no 313, de 01 de julho de 2010.
} 


\subsubsection{Autogestão como um dos regimes de construção}

A autogestão estava dentre os regimes de construção admitidos ${ }^{57}$, inicialmente com a denominação de administração direta, conceito inspirado na Lei de Licitações (Lei 8.666/1993), onde seu artigo 6º trata da "Execução direta - a que é feita pelos órgãos e entidades da Administração, pelos próprios meios". No entanto, desde o PCS, essa modalidade estava pouco definida, admitindo uma série de interpretações distintas a depender do agente financeiro local e da entidade. Apenas após 2014, houve uma definição melhor do que o programa entendia como autogestão:

\section{REGIMES DE CONSTRUÇÃO}

\subsection{SOB AUTOGESTÃO}

6.1.1 É a utilização exclusiva de meios próprios para a gestão da produção das $\mathrm{UH}$, conjugadas ou não com a contratação de profissionais ou empresas para execução parcial dos serviços necessários, nos seguintes regimes construtivos, de forma exclusiva ou conjugados:

a) autoconstrução: cada beneficiário produz sua UH;

b) mutirão ou ajuda mútua: todos os beneficiários produzem todas as $\mathrm{UH}$;

c) administração direta: a E.O e/ou CAO contrata profissionais ou empresas para execução parcial dos serviços necessários (IN 39, 2014).

Desde a sua concepção, o programa admitiu que a chamada "entidade organizadora" pudesse adotar o regime de empreitada global para a execução dos projetos e das obras. A partir de 2014, esse regime passou a ser chamado de cogestão, também com uma definição mais precisa:

\subsection{SOB COGESTÃO}

6.2.1 É a utilização de empresa do ramo da construção civil para produção total das $\mathrm{UH}$, no seguinte regime construtivo:

a) empreitada global: a E.O e/ou CAO contrata empresa especializada para execução total das obras e serviço por preço certo e total, mediante a formalização de contrato de empreitada global, permanecendo a gestão do empreendimento sob a responsabilidade da E.O e/ou CAO (IN 39, 2014).

Além disso, uma série de empecilhos formais e restrições nas tratativas com o agente financeiro demonstravam que a empreitada global seria a modalidade padrão

\footnotetext{
${ }^{57}$ A Resolução 141 elencava os seguintes regimes de construção: a) autoconstrução; b) sistema de auto-ajuda ou mutirão; c) administração direta e autogestão, e d) empreitada global.
} 
do programa e que uma série de exigências adicionais eram apresentadas quando a associação propunha a adoção de outro regime.

A UNMP tem afirmado, ao longo do tempo, que o regime de autogestão deveria ser priorizado pelos programas destinados a movimentos e cooperativas, defendendo os ganhos políticos e de resultados desse sistema, em detrimento da empreitada global.

No regime de construção por cogestão, o movimento decide por entregar todo este controle de projeto e de obra para uma empresa a construtora, que funciona dentro da lógica capitalista de obter o maior lucro possível com a administração da obra (UNMP, 2019, p. 18).

No entanto, ainda que sem informações precisas sobre as contratações do MCMV-E, é possível afirmar que a maioria dos empreendimentos foram contratados sob regime de empreitada global ou cogestão.

Uma das regras que desfavoreciam autogestão era a redução do valor da unidade quando o empreendimento adotasse regime distinto à empreitada global.

9.1.2 Para os demais regimes de construção permitidos no Programa, os valores serão reduzidos em $8 \%$ (oito por cento), exceto para propostas da modalidade de "requalificação de imóveis urbanos".

9.2 A redução prevista no subitem anterior poderá ser reincorporada aos valores da operação, desde que direcionada à ampliação da área construída por UH e/ou a construção de equipamentos comunitários no empreendimento, limitada ao valor máximo de operação definidos por Unidades da Federação ou ao valor de investimento aprovado, o menor dos dois.

A justificativa era de que nesses regimes não haveria o lucro da empresa construtora e, portanto, o valor final da unidade seria menor. A associação poderia reaver esse valor se apresentasse projeto com tamanho maior da unidade habitacional do aquele estipulado como mínimo para o programa ou equipamentos de uso comunitário, em valor equivalente.

Outra exigência presente em todos os normativos do programa era que, caso a associação não adotasse o regime de empreitada global,

"é obrigatório que o Responsável Técnico ou a Assessoria Técnica da Entidade Organizadora comprove, junto ao Agente Financeiro, acervo técnico compatível ao projeto elaborado". (IN 9, 2016). 
Para a empreitada global, apenas eram exigidas garantias financeiras, que era a que a empresa fosse aprovada no processo de análise de risco da Caixa (GERIC), muito mais relacionada com sua capacidade financeira do que que com a capacidade ou experiência técnica.

$\mathrm{Na}$ última etapa do programa houve o questionamento da área de normas e padrões da caixa sobre a adoção do percentual de Bônus e Despesas Indiretas (BDI) nos empreendimentos executados por autogestão, com a alegação de que como não se tratava de atividade lucrativa, o item "bônus" não deveria constar dos orçamentos dos empreendimentos. As entidades entendiam que a supressão dos 8\% acima apresentada já eram suficientes para demarcar essa questão. Em seguida, foi exigido que as associações abrissem os itens que compunham o BDI em seus orçamentos, exigência considerada descabida tanto porque já existia um padrão de BDI admitido para as obras públicas, quanto por essa exigência nunca ter sido feita às empresas privadas.

\subsubsection{Seleção das famílias participantes}

A formação do grupo de famílias participantes de um empreendimento autogestionário antecede a sua contratação no programa habitacional. Afinal, para chegar às condições de contratação

O Ministério das Cidades regulamentou essa questão por meio de diversas portarias sucessivas. A primeira portaria publicada sobre o assunto foi a $n^{\circ} .140$, de 5 de abril de 2010. Toda a portaria regula os procedimentos para a seleção de famílias para o FAR, colocando apenas uma sessão para o MCMV-E:

\section{SELEÇÃO DA DEMANDA AO PMCMV ENTIDADES}

As entidades sem fins lucrativos são responsáveis por fixar os critérios de seleção da demanda, os quais deverão ser divulgados nos meios de comunicação no município.

Essa forma gerou divergências na interpretação da portaria, que ora aplicava todo o seu conteúdo para a seleção de demanda do FAR no FDS, ora apenas solicitavam a indicação da demanda dentro das regras de enquadramento ${ }^{58}$. A portaria $n^{\circ}$ 610, de 26 de dezembro de 2011 detalhou melhor os procedimentos de

\footnotetext{
${ }^{58}$ As regras de enquadramento durante todo o programa eram: a) renda familiar bruta abaixo do teto vigente, b) não estar inscrito no CADMUT, c) não possuir imóvel em qualquer unidade da federação.
} 
seleção, mas ainda traziam as regras aplicáveis ao FDS em meio às regras do FAR. Somente com a portaria no 412, de 6 de agosto de 2015, já depois de muitos questionamentos ao programa, estabeleceu-se um regramento específico ao MCMV-E, já com algumas restrições para a atuação das associações e cooperativas.

Esses normativos previam que a entidade organizadora poderia adotar para 0 processo de seleção das famílias participantes, além dos três critérios nacionais do programa $^{59}$, três critérios adicionais, definidos em assembleia geral da entidade. Até 2015, não havia qualquer cerceamento ao tipo de critério a ser adotado, no entanto, a partir da Portaria 412, o MCidades apresentou uma lista prévia de 17 critérios que deveriam ser escolhidos pelas entidades. Se, até então, a maioria dos critérios de seleção das associações e cooperativas se referiam à participação da família em atividades do movimento social, esses novos critérios do Ministério tratavam tão somente da condição socioeconômica da família.

A participação no processo de elaboração da proposta e conquista do empreendimento foi considerado requisito de participação para integrar o grupo de elegíveis para o empreendimento.

2.1.3. Deverão ser considerados os requisitos de participação:

a) adesão à proposta do empreendimento;

b) participação nas atividades da EO; e

c) participação nas ações necessárias à elaboração do projeto e contratação do empreendimento. (Portaria 595)

Caso o número de famílias elegíveis fosse maior do que o número de unidades previstas, a entidade deveria proceder à hierarquização por meio dos critérios previstos.

Essas regras tentaram responder a críticas, denúncias e recomendações dos órgãos de controle e do Ministério Público acerca do papel dos movimentos sociais na definição dos beneficiários da política pública, numa clara tentativa de cerceamento da organização popular e da autogestão. Os movimentos argumentam que a existência do programa, por si só, não garante o acesso à moradia, mas que a mobilização e organização são essenciais para a apresentação e contratação de

\footnotetext{
${ }^{59}$ Os critérios nacionais de priorização eram: a) mulher chefe de família, b) moradores de áreas de risco e c) famílias com pessoa com deficiência.
} 
uma proposta habitacional. Nesse sentido, a proposta pertence àquele grupo de famílias organizadas representadas pela associação.

Uma outra questão que teve que ser enfrentada pelas associações e cooperativas foi a exigência de inclusão das famílias dos empreendimentos no Cadastro Único para Programas Sociais (CadÚnico) e a atribuição ao município da competência de vinculação do CadÚnico ao empreendimento e envio para o Sistema de Tratamento de Arquivos Habitacionais da Caixa Econômica Federal (SITAH) para enquadramento da demanda.

O CadÚnico é uma base de dados do Ministério do Desenvolvimento Social que deveria ser utilizada para a definição de beneficiários de todos os programas sociais e é alimentado pelas prefeituras municipais por meio dos Centros de Referência de Assistência Social (CRAS). A inclusão de uma família no sistema não significa necessariamente sua inclusão em algum desses programas sociais e deveria ser um ato administrativo aberto a todos os interessados.

No entanto, algumas prefeituras passaram a dificultar a inscrição da "demanda do movimento" no cadastro ou a exigir a inclusão de parte de seu cadastro na demanda do empreendimento quando da transmissão ao SITAH. Essa medida limitou a autonomia do movimento na organização das famílias e gerou alguns conflitos que, em alguns casos, resultou na inclusão ao grupo associativo de famílias estranhas a ele.

\subsubsection{Direito à Assessoria Técnica}

Desde a sua concepção e também baseando-se na experiência do Programa Crédito Solidário, o componente assistência técnica esteve presente no MCMV-E. A lei que criou o MCMV incluiu em seu artigo 4 o seguinte parágrafo: "§ $2^{\circ}$. A assistência técnica deve fazer parte da composição de custos do PNHU" (Lei 11.977/2009). A contribuição dos movimentos à discussão trouxe a concepção utilizada nos programas com autogestão, ou seja, que a equipe de assessoria técnica deveria ser apresentada pela associação ou cooperativa. O agente financeiro apenas regularia as condições para essa atuação, como exigência de experiência prévia, apresentação de responsável técnico e anotação de responsabilidade técnica e não poderia interferir na escolha da equipe que acompanharia o projeto. Cabe lembrar que a contratação do empreendimento 
envolvia apenas a associação ou cooperativa e o agente financeiro; a equipe de assessoria não fazia parte do contrato. De acordo com diversas resoluções do programa "A elaboração do projeto e a obtenção das aprovações necessárias são de responsabilidade da Entidade Organizadora60" A relação entre assessoria e associação era uma relação privada e deveria ser negociada entre essas duas partes somente.

No entanto, não foi incomum a influência do agente financeiro nessa relação, por vezes tratando aspectos do empreendimento diretamente com a equipe de assessoria técnica ou até induzindo a seleção ou não de determinada equipe.

Inicialmente, para a contratação dos empreendimentos, era necessário que o projeto estivesse completamente elaborado e licenciado nos órgãos responsáveis. Isso exigia um investimento inicial e de risco das famílias, entidades e assessorias técnicas, o que impedia a participação de diversos grupos. Caso a operação não fosse contratada, todo o investimento seria perdido. Nesse sentido, desde o início do programa, foi proposto pelos movimentos a possibilidade de contratação de projetos em fase anterior à fase de obras. Isso se concretizou por meio da regulamentação da modalidade "para aquisição de terreno e pagamento de Assistência Técnica para elaboração de projetos, vinculados ao processo de financiamento para a produção de unidades habitacionais" na Resolução n. 143, de 26 de novembro de 2009. Posteriormente foi criada uma nova modalidade para pagamento de projeto em imóveis públicos doados ou cedidos para o programa.

$\mathrm{Na}$ maioria dos normativos do programa, os valores para a elaboração de projeto estavam definidos, por meio de um percentual do valor da operação, sendo inversamente proporcional à quantidade de unidades do empreendimento:

“I. Limitado a $3 \%$ (três por cento) do custo de produção total para projetos com até 100 (cem) unidades habitacionais;

II. Limitado a $2 \%$ (dois por cento) do custo de produção total para projetos que apresentem entre 101 (cento e uma) a 300 (trezentos) unidades habitacionais; e

III. Limitado a 1,5\% (um e meio por cento) do custo de produção total para projetos que apresentem mais de 300 (trezentas) unidades habitacionais" $"$.

\footnotetext{
${ }^{60}$ Resolução 200/2014

${ }^{61}$ Resolução 200/2014
} 
Por diversas vezes essa medida foi questionada por não levar em consideração a distinção de complexidade de elaboração e aprovação em diferentes situações, mas tal medida nunca foi alvo de excepcionalidades por parte do gestor do programa.

Outro fator de divergências foi a definição, por parte do gestor do programa, das especificações mínimas para as unidades habitacionais e sua implantação. Esse tema foi alvo de críticas desde o seu lançamento, tanto porque estabelecia parâmetros nacionais sem considerar diferenças regionais, quanto por limitar e induzir a elaboração de projetos padrão. As especificações foram ampliando a sua complexidade ao longo do programa, e incluiu, por exemplo, a acessibilidade universal e a adoção da norma de desempenho para os materiais utilizados (ABNT NBR $15575^{62}$ ). Uma das características da autogestão é a discussão e elaboração de projeto com a participação das famílias participantes do empreendimento, adotando soluções que atendam às suas expectativas e melhor adaptação às características da área e do entorno, bem como favorecer a qualidade do ambiente urbano. As especificações muitas vezes limitavam essa ação. Tampouco, os analistas do agente financeiro demonstravam interesse e raramente apoiavam soluções inovadoras no desenho ou na utilização de materiais.

A área mínima exigida, áreas construídas de $42 \mathrm{~m}^{2}$ para apartamento e $38 \mathrm{~m}^{2}$ para casa ${ }^{63}$ também foi alvo de várias críticas por ser considerada muito pequena para uma família. Na autogestão, em geral, as áreas construídas superaram esse padrão mínimo. Na Revista da Produção de Habitação em Autogestão, a UNMP afirma que "A área média da unidade habitacional é $52,34 \mathrm{~m}^{2}$ e a área média de varredura da UH é de 44,18 m" (UNMP, 2019, p.17). Em alguns empreendimentos essa área chegou a cerca de $60 \mathrm{~m}^{2}$.

Nos primeiros normativos, a exigência de equipe de assessoria técnica para acompanhamento da execução das obras foi adotada exclusivamente para o regime de construção por autogestão ou administração direta. No entanto, posteriormente, tal exigência foi estendida para todos os regimes de construção. Ainda assim, havia certa imprecisão em quais serviços e responsabilidades estariam alocados nessa rubrica do orçamento. No MCMV-E, " O somatório dos itens "projeto", "assistência técnica" e "administração da obra", financiados pelo FDS, está limitado a $8 \%$ (oito

\footnotetext{
${ }^{62}$ Norma de Desempenho de Edificações, da Associação Brasileira de Normas Técnicas (ABNT).

${ }^{63}$ Portaria $141 / 2010$.
} 
por cento) do Valor da Operação" (IN 39/2015), o que levou a algumas dificuldades e conflitos tanto devido o limite importa, considerado insuficiente por algumas associações e assessorias, como pela falta de distinção entre o que comportaria a assistência técnica e o que seria considerado administração de obras.

\subsubsection{Participação direta na tomada de decisão}

O MCMV-E exigia a formação de apenas duas comissões para a gestão do empreendimento, a Comissão de Acompanhamento de Obras (CAO) e a Comissão de Representantes do Empreendimento. Ambas deveriam ser eleitas em assembleia convocada pela EO, com registro em Ata, composta por mínimo três pessoas, sendo duas do grupo de beneficiários dos projetos e com membros distintos entre $\mathrm{si}^{64}$. $\mathrm{A}$ CAO tinha como objetivo o desenvolvimento físico da obra e o acompanhamento das vistorias e medições feitas pelo agente financeiro. A CRE fazia toda a movimentação financeira dos recursos disponibilizados para o contrato.

Nos normativos, além de algumas assembleias para assuntos específicos, como eleição da CAO e CRE, aprovação do regulamento de mutirão, quando existente ou alguma mudança no curso da obra, não havia nenhuma instância regulamente prevista para a participação do conjunto de famílias integrantes do empreendimento. Nem mesmo estava prevista a prestação de contas dos recursos recebidos ou instâncias para decisões ordinárias da obra, como a contratações de empresas, assessoria técnica ou fornecedores.

Dessa forma, ficava facultado à entidade organizadora a forma de democratização na gestão do empreendimento. Se, por um lado, isso dava maior autonomia para os grupos se organizarem da maneira mais adequada à sua realidade, também demonstrava a pouca importância dada pelo gestor do programa aos mecanismos de participação. Havia uma exigência muito maior na regularidade formal dos procedimentos de obra de que na efetiva mobilização coletiva.

A autogestão caracteriza-se exatamente por uma complexa estrutura para garantir a tomada de decisão coletiva, com capacitação de seus membros, organização horizontal e eficiência na produção habitacional. O processo estimula o envolvimento do conjunto de famílias seja por meio da participação nas

\footnotetext{
${ }^{64}$ Resolução 141/2009.
} 
assembleias, nas comissões de gestão e nas formas de representação. É comum que grupos que adotam a autogestão organizem diversas comissões com temas específicos para tratarem de diversos aspectos do processo de produção ao mesmo tempo que organizam a nova comunidade que se forma a partir da construção do empreendimento.

Outro aspecto fundamental trata da exigência da transparência e da prestação de contas dos recursos recebidos a todos os integrantes do grupo. $O$ MCMV-E adota o sistema de medição física para avaliar o avanço de obra, baseado no orçamento aprovado à época da contratação do empreendimento. Deferente, por exemplo, dos programas municipais e estadual em São Paulo, em que, além do avanço físico era exigido a prestação de contas contábil de toda a movimentação financeira, o MCMV-E não estabelecia a apresentação desses documentos. Processos autogestionários exigem, no entanto, que, independente da regulação feita pelo poder público, o conjunto dos integrantes do grupo devem ter conhecimento e poder de intervenção sobre os recursos colocados sob sua responsabilidade. Comissões de prestação de contas, conselho fiscal e aprovação das contas em assembleia devem fazer parte do cotidiano do grupo.

Destaca-se nos normativos do MCMV-E que a realização de assembleia dos participantes é exigida quando da existência de algum problema que impeça a conclusão da obra.

"21.4 Nas situações em que a Entidade Organizadora der causa à ineficácia contratual, a mesma poderá ser substituída mediante assembleia dos beneficiários registrada em ata e após anuência dos Agentes Financeiro e Operador e Secretaria Nacional de Habitação, independente de outras sanções legais" (Resolução 200/2014).

O que chama a atenção nesse e em outros dispositivos dos normativos é que a entidade organizadora e os chamados beneficiários não são vistos pelo gestor do programa como parte de um mesmo ente, mas que têm interesses diferentes e até conflitantes. Interessante salientar que parte dos movimentos populares inclusive rejeitam a expressão "beneficiários", adotando a denominação "participantes", enfatizando a responsabilidade coletiva de seus integrantes.

No entanto, ao longo do programa foram observadas situações onde ficava evidente da falta de vínculo entre a demanda, a associação e o empreendimento, com um distanciamento do processo de gestão e acompanhamento da obra. Houve, 
inclusive, denúncias de que empresas privadas teriam cooptado entidades habilitadas para apresentar seus próprios projetos, numa prática que ficou popularmente conhecida como "barriga de aluguel".

\subsubsection{Mutirão}

O conceito de mutirão também foi pouco definido no MCMV-E. Inicialmente a expressão "sistema de autoajuda em mutirão" foi definido como um dos regimes de construção na IN 36/2010. No entanto, na interpretação do agente financeiro, esse regime seria adotado quando não houvesse nenhuma mão de obra contratada, além da assessoria técnica, para a produção do empreendimento. Não há notícia que nenhum empreendimento tenha sido construído dessa forma, mesmo aqueles de estrutura mais simples. Nos empreendimentos com autogestão, em geral, pode-se ou não adotar o sistema de mão-de-obra voluntária dos participantes em complemento à mão-de-obra contratada, sendo esta em maior proporção quanto maior a complexidade do projeto.

$\mathrm{Na}$ Resolução 200, finalmente, a denominação do regime de construção passou a ser autogestão e a IN 39 permitiu a utilização do mutirão e da administração direta (com a contratação de parte da mão de obra) simultaneamente, o que já vinha ocorrendo em diversos empreendimentos.

Ao longo do programa, as associações e cooperativas passaram a contabilizar o trabalho mutirante incluindo seus valores na planilha orçamentária, denominada "contrapartida em mão-de-obra". Isso permitiu a medição do trabalho executado coletivamente, dando visibilidade na sua importância ao processo.

Além disso, quando da adoção do mutirão no empreendimento, a associação ou cooperativa deveria apresentar à Caixa o regulamento de obras aprovados pela assembleia dos participantes do empreendimento, assegurando seu compromisso de aportar as horas de trabalho acordadas.

\subsubsection{Trabalho Social}

A destinação de recursos para a execução do Trabalho Social foi um ganho importante para o processo de produção habitacional. NO PCS já havia esse dispositivo, com uma escala bem menor. No MCMV-E destinou-se de 1,5 a $2 \%$ do 
valor da operação para o Projeto Técnico de Trabalho Social que abrangia a fase anterior à contratação do empreendimento, a fase de obras e a fase de pósocupação. Importante ressaltar que os mesmos percentuais eram aplicados ao MCMV FAR, porém o trabalho social nesse programa se resumia a poucos meses anteriores a entrega do empreendimento e à fase de pós-ocupação. Ou seja, cabia às associações e cooperativas realizar um projeto muito maior, com os mesmos recursos.

Ao mesmo tempo que eram feitas as análises de engenharia, a equipe de Trabalho Social deveria elaborar o projeto de Trabalho Social para a etapa de obras e de pós ocupação. O normativo de Trabalho Social do Ministério das Cidades e o Cadernos de Orientações da Caixa não se adequavam a processos autogestionários, pois não incluíam os processos de gestão coletiva da produção habitacional. Nesse sentido, os projetos continham duas partes: aquela exigida pelos normativos do programa e outra, com as questões relacionadas ao funcionamento da autogestão.

\subsubsection{Orçamento e aportes}

Os orçamentos apresentados no momento da contratação da fase de obras devem ser baseados na tabela SINAPI ${ }^{65}$, de forma a detalhar cada um dos insumos de obra, com seus custos unitários. A regra aplicada ao MCMV-E e a grande parte de programas do governo federal impede qualquer forma de reajuste do valor contratado até a conclusão das obras, não importando o prazo que levem. Nesse sentido, o contrato fica desprotegido por possíveis variações de mercado desses itens e, quanto mais longa for a obra, maior o desequilíbrio financeiro que o contrato acumulará.

Qualquer valor adicional necessário é tratado como "suplementação" e somente podem ser aprovados por meio da demonstração de "fatores supervenientes", analisados de forma bastante subjetiva pelos Agentes Financeiro e Operador do Programa. Não é permitido, por exemplo, a solicitação de valor

\footnotetext{
${ }^{65}$ A tabela SINAPI (Sistema Nacional de Pesquisa de Custos e Índices da Construção Civil) é uma tabela utilizada no orçamento de obras, mantida pela Caixa Econômica Federal e pelo IBGE, que informa os custos e índices da Construção Civil no Brasil, com atualizações mensais.
} 
suplementar para mudanças de preço de determinado item ao longo do contrato, ainda que a atualização da tabela SINAPI o comprove.

Parte desses desequilíbrios acabam sendo absorvidos pelo valor destinado ao $\mathrm{BDI}$ atribuído à obra, porém nem sempre os valores são suficientes face a essas variações, fazendo com que cada associação tivesse que buscar alternativas para eventuais déficits de obra.

\subsubsection{Propriedade Coletiva}

A propriedade, se vista do ângulo do direito civil, não é senão um direito subjetivo, consistente em assegurar a uma pessoa o monopólio da exploração de um bem e de fazer valer esta faculdade contra todos que eventualmente queiram a ela se opor. Se, contudo, mudarmos o enfoque da questão e passarmos a considerar a propriedade nas suas relações com o Poder Público, a sua natureza ganha uma coloração bastante diversa. É que aqui a propriedade interfere na própria estrutura do Estado, sendo perfeitamente discerníveis atualmente no mundo os países que a asseguram de maneira ampla (Estados predominantemente liberais) e aqueles outros que a negam pelo menos quando têm por objeto os bens geradores de riqueza (Estados de ideologia marxistaleninista).

Do ponto de vista da sua conceituação, o que se vê é que a propriedade, no direito civil, consiste na fruição plena e exclusiva, por uma pessoa, de um determinado bem corpóreo. A sua definição seria, portanto, extraível das prerrogativas que o domínio oferece: usar, gozar, dispor e o de reivindicar a coisa de quem quer que indevidamente a detenha.

O conceito constitucional de propriedade é mais lato do que aquele de que se serve o direito privado. É que do ponto de vista da Lei Maior tornou-se necessário estender a mesma proteção, que, no início, só se conferia à relação do homem com as coisas, à titularidade da exploração de inventos e criações artísticas de obras literárias e até mesmo a direitos em geral que hoje não o são a medida que haja uma devida indenização da sua expressão econômica.

A propriedade tornou-se, portanto, o anteparo constitucional entre o domínio privado e o público. Neste ponto reside a essência da proteção constitucional: é impedir que o Estado, por medida genérica ou abstrata, evite a apropriação particular dos bens econômicos ou, já tendo esta ocorrido, venha a sacrificá-la 
mediante um processo de confisco. É certo existirem bens inapropriáveis pelos indivíduos, mas estes

Constituem o domínio público constitucionalmente definido. É certo de outra parte que os proprietários podem ter os seus bens lesados por outros particulares, mas para coibir estes abusos, basta a legislação ordinária. É por isto que vemos na proteção constitucional da propriedade uma limitação da esfera do Estado no campo econômico. Não há que negar-se que esta proteção não é absoluta. A própria tributação é uma forma de apropriação estatal de bens privados. A desapropriação também. Mas ambos os institutos têm de ser utilizados na forma constitucional.

A referida multiplicidade de propriedades leva a uma correspectiva diversificação dos regimes jurídicos de cada uma.

É que a nossa Carta, malgrado algumas incursões estatizantes ou nacionalistas, ainda assim é um documento eminentemente consagrador do liberal capitalismo.

No nosso sistema, a propriedade privada tanto colabora para a expressão da individualidade, quando incidente sobre meios de produção, quanto sobre bens de consumo. Daí porque no nosso sistema constitucional a propriedade estar simultaneamente vinculada ao regime das liberdades pessoais que estatui como também à própria ordem econômica.

As restrições ao direito de propriedade que a lei poderá trazer só serão aquelas fundadas na própria Constituição, ou então nas concepções aceitas sobre o poder de polícia.

Como direito fundamental ela não poderia deixar de compatibilizar-se com a sua destinação social. Aliás, tem sido uma constante nestes nossos comentários a evidenciação de como mesmo os mais absolutos direitos, tais como formulados no Texto, acabam por submeter-se à necessidade de harmonizar-se com os fins legítimos da sociedade.

Mesmo naqueles que nada prescrevem sobre a sua destinação social, fica implícito que hão de encontrar limites no exercício dos outros direitos individuais.

O cerne do nosso sistema jurídico-político repousa no fato de que não há uma oposição irrefragável entre o social e o individual ou mesmo de que o social avança na medida em que se sufocam os direitos individuais. A feição ainda predominantemente liberal da nossa Constituição acredita que há uma maximização do atingimento dos interesses sociais pelo exercício normal dos direitos individuais. 
O liberalismo não consagra a propriedade como privilégio de alguns, mas, sim, acredita ser a gestão individual do objeto do domínio a melhor forma de explorá-lo, gerando destarte o bem social. Este não é senão um subproduto natural e espontâneo da livre atuação humana que, motivada pela recompensa que pode advir da exploração do bem, sobre ele exerce uma criatividade e um trabalho sem equivalente nos países que a renegam.

Portanto, há uma perfeita sintonia entre a fruição individual do bem e o atingimento da sua função social. Só esta harmonia e compatibilização podem explicar por que os países que mais se desenvolvem economicamente são os que o fazem sob a modalidade do capital privado.

A função social visa a coibir as deformidades, o teratológico, os aleijões, digamos assim, da ordem jurídica. É o que cumpre examinar agora. Vale dizer, em que consistem aquelas destinações que poderão levar ao uso degenerado da propriedade a ponto de colocar o seu titular em conflito com as normas jurídicas que a protegem.

A chamada função social da propriedade nada mais é do que o conjunto de normas da Constituição que visa, por vezes até com medidas de grande gravidade jurídica, a recolocar a propriedade na sua trilha normal.

Não há um regime único da função social porque também são diversos os domínios sob os quais se exerce a propriedade. O que se pode dizer é que a Constituição se interessou sobretudo pelos bens materiais, mais especificamente 0 domínio da terra, quer rural, quer urbana.

Queiramo-lo ou não, seja ou não do nosso gosto pessoal, o fato é que os objetivos fundamentais dos Estados modernos continuam a ser aqueles voltados ao desenvolvimento do seu potencial econômico.

A propriedade coletiva ou cooperativa das unidades habitacionais nunca foi admitida no programa. A concepção vigente durante todo o período foi a da individualização das matrículas das unidades habitacionais para concessão do financiamento individual, com alienação fiduciária ao FDS. Inicialmente, todas as unidades já deveriam estar individualizadas por meio de registro de loteamento ou incorporação imobiliária no início do contrato com o contrato de financiamento do FDS com cada uma das pessoas físicas beneficiárias. Posteriormente se admitiu o contrato com a entidade organizadora como representantes temporárias dos 
beneficiários finais, mas sempre com a obrigatoriedade de individualização da matrícula ao final da obra.

Documentos dos movimentos apresentados em diversas ocasiões ao Ministério das Cidades propunha a adoção da propriedade coletiva como alternativa à propriedade individual. No entanto, essa proposta não contou com apoio de todas as organizações e tampouco avançou nas discussões junto ao governo. 


\section{5 - Os efeitos das limitações políticas e jurídicas nos empreendimentos habitacionais Florestan Fernandes e José Maria Amaral.}

Neste capítulo, será apresentada na forma de um estudo de caso, o histórico e os desafios da execução de dois empreendimentos contratados no Programa Minha Casa Minha Vida Entidades: os empreendimentos Florestan Fernandes e José Maria Amaral.

$\mathrm{Na}$ realidade, embora formalmente sejam considerados dois empreendimentos distintos, ambos os projetos existem fisicamente no mesmo terreno, fruto do mesmo processo de luta. A divisão em dois empreendimentos deuse apenas por razões urbanísticas. Faz parte da tradição da entidade organizadora, executar empreendimentos menores como forma de contribuir para uma boa convivência na pós ocupação. A área comportava, segundo os estudos iniciais, cerca de 600 unidades habitacionais, respeitando-se os parâmetros da legislação, mas durante os debates da concepção do projeto, optou-se pela execução de uma quantidade de unidades que garantisse uma compatibilidade entre o potencial construtivo e a qualidade de vida decorrente da implantação.

Os empreendimentos foram contratados em nome da entidade Movimento dos Trabalhadores Sem Terra Leste 1, filiado à União dos Movimentos de Moradia de São Paulo, na Cidade Tiradentes, cidade de São Paulo.

Os mutirões contaram com a assessoria técnica Ambiente Arquitetura desde a busca e compra de terreno, a fase de projeto e licenciamento e também na fase de obras. O trabalho técnico social e a assessoria jurídica foram feitos pelo próprio movimento.

Os empreendimentos foram contratados na modalidade aquisição de terreno e construção e no regime de construção denominado administração direta, com autogestão.

Tabela 6 - Dados dos empreendimentos Florestan Fernandes e José Maria Amaral

\begin{tabular}{l|c|c}
\hline \multicolumn{1}{c|}{ Característica } & \multicolumn{2}{|c}{ Ambos os conjuntos } \\
& FF & \multicolumn{2}{|c}{ JMA 1} \\
\hline Zoneamento do terreno: & \multicolumn{2}{|c}{$18.770,67 \mathrm{~m}^{2}$} \\
\hline Tamanho do terreno: & $9.385,33 \mathrm{~m}^{2}$ & $9.385,34 \mathrm{~m}^{2}$ \\
\hline $\begin{array}{l}\text { Tamanho do terreno de cada } \\
\text { condomínio }\end{array}$ & $1.804,99 \mathrm{~m} 2$ & $1399,39 \mathrm{~m} 2$ \\
\hline Área de APP: & & \multicolumn{2}{|c}{} \\
\hline
\end{tabular}




\begin{tabular}{|c|c|c|}
\hline Quantidade de UH & 198 & 198 \\
\hline Quantidade de blocos & 4 & 4 \\
\hline Número de pavimentos: & $\begin{array}{l}\text { Bloco A :10 pav/ Bloco B : } \\
12 \text { pav/Bloco C e D: } 15 \text { pav }\end{array}$ & $\begin{array}{l}\text { Bloco A: 10pav/ Bloco B: } \\
13 \text { pav/ Bloco C: } 14 \text { pav/ } \\
\text { Bloco D: } 15 \text { pav. }\end{array}$ \\
\hline $\begin{array}{l}\text { Quantidade de elevadores } \\
\text { por família: }\end{array}$ & $\begin{array}{c}1 \text { elevador a cada } 13 \\
\text { famílias }\end{array}$ & $\begin{array}{c}1 \text { elevador a cada } 13 \\
\text { famílias }\end{array}$ \\
\hline $\begin{array}{l}\text { Quantidade Total de } \\
\text { Elevadores }\end{array}$ & 16 & 16 \\
\hline Área construída: & $14.301,82 \mathrm{~m} 2$ & $14.301,82 \mathrm{~m} 2$ \\
\hline $\begin{array}{l}\text { Coeficiente de } \\
\text { aproveitamento permitido } \\
\text { pelo zoneamento: }\end{array}$ & \multicolumn{2}{|c|}{2,5} \\
\hline $\begin{array}{l}\text { Coeficiente de } \\
\text { aproveitamento utilizado: }\end{array}$ & \multicolumn{2}{|c|}{1,3} \\
\hline Taxa de ocupação: & \multicolumn{2}{|c|}{0,135} \\
\hline Área dos apartamentos & $56 \mathrm{~m} 2$ & $56 \mathrm{~m} 2$ \\
\hline $\begin{array}{l}\text { Número de vagas de } \\
\text { estacionamento }\end{array}$ & 34 & 42 \\
\hline Equipamento Comunitário & $289,59 \mathrm{~m} 2$ & $289,65 \mathrm{~m} 2$ \\
\hline Reservatório de água (tipo): & 1 reservatório tipo torre & 1 reservatório tipo torre \\
\hline $\begin{array}{l}\text { Solução de esgotamento } \\
\text { sanitário: }\end{array}$ & \multicolumn{2}{|c|}{1 estação elevatória } \\
\hline $\begin{array}{l}\text { Reservatórios de água } \\
\text { pluvial }\end{array}$ & 2 & 2 \\
\hline
\end{tabular}

Fonte: Elaborada pelo autor com base em dados coletados em campo

Tabela 7 - Linha do tempo dos empreendimentos Florestan Fernandes e José Maria Amaral

\begin{tabular}{l|l}
\hline Dez/08 & Assinatura do compromisso de compra e venda do terreno \\
\hline Abr/10 & Assinatura do contrato de Fase 1 do MCMV E - Compra do terreno \\
\hline Dez /10 & Contrapartida da Secretaria Estadual de Habitação \\
\hline Nov/11 & Aprovação do projeto na PMSP \\
\hline abr/13 & Assinatura do contrato de obras do MCMV E \\
\hline set/13 & Início efetivo das obras \\
\hline Jun/16 & Impasse sobre a utilização dos juros para conclusão da obra \\
\hline Mar/17 & Contrapartida da Secretaria Municipal de Habitação \\
\hline Jul/19 & Paralisação dos repasses do MCMV E - reprogramação \\
\hline Jan/20 & Retomada dos repasses do MCMV E \\
\hline
\end{tabular}

Fonte: Elaborada pelo autor com base em dados coletados em campo 


\subsection{Organização do Movimento Sem Terra Leste 1}

A Leste 1 se organiza, desde a sua fundação, por meio de grupos de base territoriais, chamados de "grupos de origem". É nestes grupos que todas as famílias iniciam sua participação no movimento e atuam para a conquista de um novo terreno e projeto habitacional. Assim que ingressa no movimento, em um encontro específico para esta finalidade, o novo integrante escolhe um grupo de origem, onde participará quinzenalmente de reuniões que organiza as atividades de pressão ao poder público e recebe informações acerca do andamento das negociações, de atividades de capacitação e outras atividades do movimento. Atualmente, a Leste 1 conta com 37 grupos de origem, a grande maioria (cerca de 80\%) localizados nas regiões de Sapopemba, São Mateus e Cidade Tiradentes. O movimento conta ainda com grupos em Itaquera, Itaim, Belém e Vila Prudente.

Figura 6 - Área de Abrangência do MST Leste 1

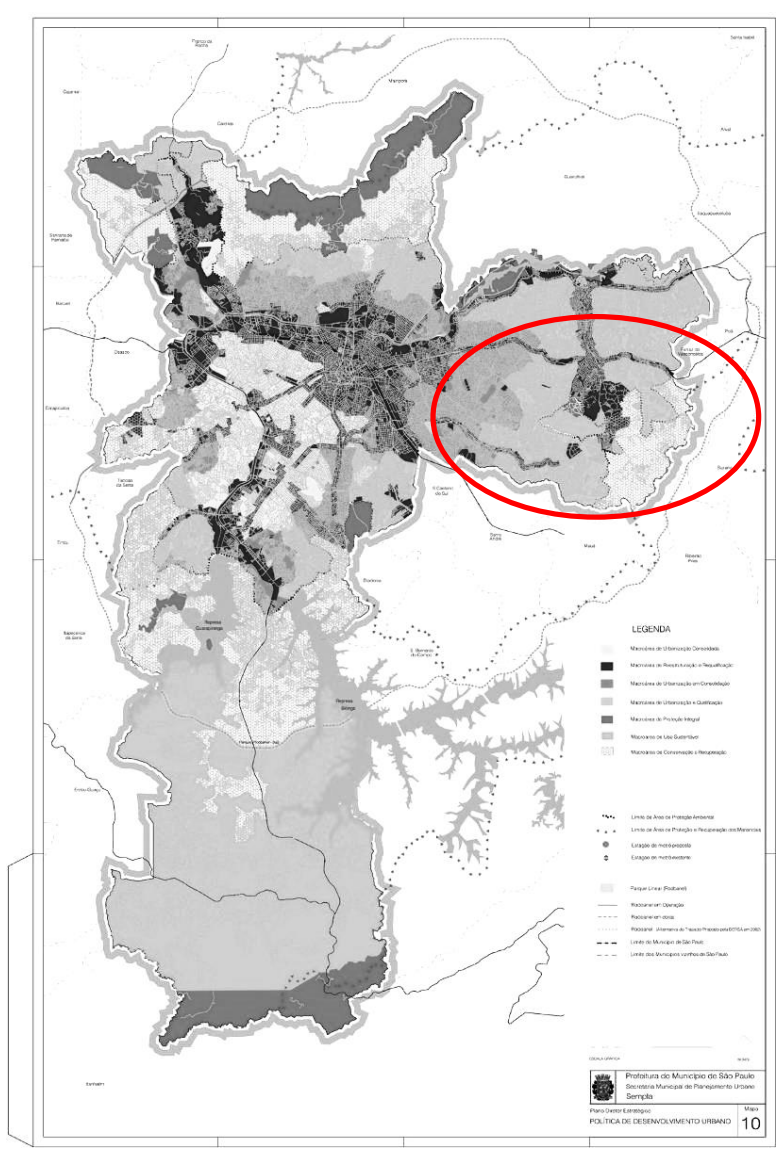

Fonte: Acervo do MST Leste 1 
Esses grupos elegem periodicamente seus coordenadores que participam da reunião semanal de coordenação ampliada e que define as estratégias a serem adotadas pelo movimento. Há ainda uma coordenação executiva, eleita pela coordenação ampliada, que tem a tarefa de conduzir as atividades, articulações e ações necessárias para a conquista e viabilização dos empreendimentos habitacionais.

Figura 7 - Atividade de acolhida novas famílias

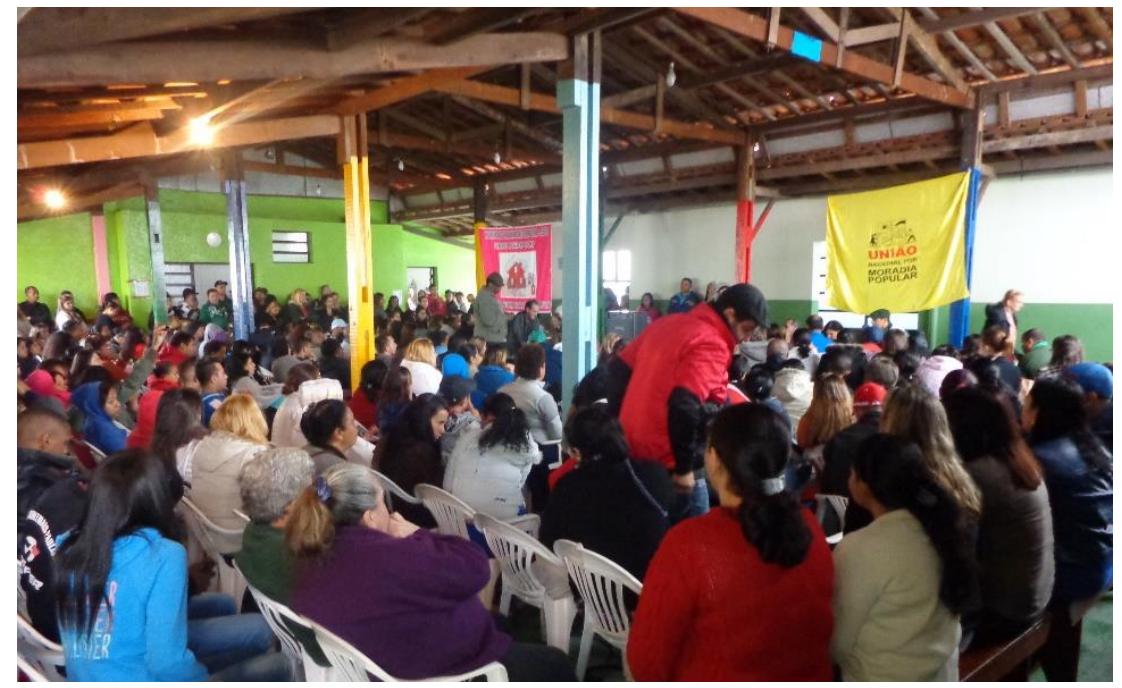

Fonte: Acervo do MST Leste 1

O movimento adota como critério para elegibilidade dos associados ao projetos habitacionais conquistados, a sua participação nas reuniões ordinárias do grupo de origem ao qual está ligado, bem como nas atividades de pressão aos órgãos públicos (atos, passeatas, manifestações, acampamentos), ocupações em imóveis vazios, atividades de participação institucional (audiências públicas, conferências, eleições de conselhos), atividades de capacitação (cursos, seminários, atividades formativas) e de solidariedade a outras lutas da classe trabalhadora.

"Sem prejuízo da observância aos critérios estabelecidos pelos órgãos financiadores dos projetos habitacionais na definição de famílias para participarem em projetos habitacionais conquistados, são adotados critérios adicionais, idênticos para todos os associados do movimento. A participação das famílias e dos grupos serão medidas por pontuação, conforme a tabela abaixo:

DA PONTUAÇÃO DAS FAMÍLIAS

\begin{tabular}{|l|l|}
\hline Atividade & Pontuação \\
\hline Ocupações (ato da ocupação) & 15 pontos \\
\hline Ocupações (por dia de permanência) & 05 pontos \\
\hline
\end{tabular}




\begin{tabular}{|l|l|}
\hline Debates/Formação - Atividade externa & 05 pontos \\
\hline Reunião de grupo & 01 ponto \\
\hline $\begin{array}{l}\text { Acompanhante (em atividades definidas pela } \\
\text { Coordenação Ampliada) }\end{array}$ & $\begin{array}{l}\text { 02 pontos cada, com } \\
\text { limite máximo de 10 } \\
\text { pessoas; }\end{array}$ \\
\hline Contribuição paga em dia & 01 ponto \\
\hline Passeata & 10 pontos \\
\hline Ida à Brasília & 10 pontos + 5 por dia \\
\hline
\end{tabular}

O coordenador do grupo deve fazer demonstrativo de pontuação das famílias mensalmente e para a coordenação executiva do Movimento que consolidará as informações de forma centralizada e dará ampla publicidade"66.

Quando o movimento conquista uma nova área e define, junto com sua assessoria técnica, o número de unidades previsto para aquele empreendimento, a coordenação ampliada divide esse número pelos grupos de origem existentes, proporcionalmente à participação de cada grupo nas atividades realizadas no período imediatamente anterior.

À época da formação do grupo de famílias dos Mutirões Florestan Fernandes e José Maria Amaral, o movimento adotava um controle manual das participações, por meio do arquivamento de listas de presença de cada atividade e, no momento da divisão das vagas nos projetos habitacionais, somava a participação de cada grupo e dividia proporcionalmente as vagas. Atualmente, a Leste 1 conta com um sistema informatizado e disponível na internet para esse controle, garantindo maior fidelidade das informações e transparência para as famílias associadas.

Em seguida, os coordenadores de grupo são responsáveis por apresentar a lista hierarquizada das famílias para a atribuição das vagas que foram destinadas àquele grupo. As famílias são consultadas se desejam integrar aquele projeto sucessivamente até que se completem as vagas. Não é incomum, que uma família que estaria classificada para aquela vaga, decida por não aceita-la, devido, por exemplo, à localização do futuro empreendimento. Quando isso ocorre, a vaga é oferecida à próxima família da lista hierarquizada.

\footnotetext{
${ }^{66}$ Regimento da Leste 1 vigente em 2008.
} 


\subsection{Formação do grupo}

A primeira parte das famílias que compuseram a demanda dos Mutirões Florestan Fernandes e José Maria Amaral foi constituído em 2005, para apresentar um projeto para o Programa Crédito Solidário. O Movimento chegou a avançar bastante no desenvolvimento de projeto, em parceria com a Grão Assessoria, na área "Luís Mateus", na Cidade Tiradentes. No entanto, todo o trabalho foi perdido devido à dívida de IPTU de seus proprietários, fazendo o grupo voltar à estaca zero. Devido à frustração do projeto, muitas das famílias envolvidas no projeto acabaram voltando para os seus grupos de origem ou saindo do movimento.

As famílias remanescentes foram fundamentais para a formulação de uma nova estratégia para a viabilização de uma nova proposta, bem como o "Grupo de Terras", como veremos abaixo.

Em 2008, já com uma a área identificada e um novo número de unidades previstas, novamente a Leste 1 distribuiu as vagas segundo os critérios de participação e novas famílias se somaram ao grupo original.

A demanda do projeto foi composta, portanto, por famílias dos diferentes grupos de origem, moradoras em diversos bairros da Zona Leste. Todas elas foram enquadradas nos critérios do programa, que definia a renda máxima como $\mathrm{R} \$$ 1.350,00, cerca de 3 salários mínimos, à época. Em diagnóstico realizado pela equipe de Trabalho Social ${ }^{67}$, verificou-se que $70 \%$ das famílias eram chefiadas por mulheres, um aspecto bastante relevante para o movimento de moradia. 55\% dos titulares se declarava preto ou pardo e quase $70 \%$ era natural de São Paulo ou Região Metropolitana. Sobre as condições de moradia, cerca de $50 \%$ pagava aluguel e $50 \%$ morava em casas cedidas ou em coabitação familiar.

\subsection{Busca do terreno}

O Movimento Sem Terra Leste 1, desde 2005, constituiu um "Grupo de Terras", formado por integrantes dos grupos de origem, que ficou responsável por buscar terrenos à venda e receber sugestões vindas dos participantes do

\footnotetext{
${ }^{67}$ Dados obtidos no Projeto de Trabalho Técnico Social dos empreendimentos, 2011. Acervo do MST Leste 1.
} 
movimento. A partir daí, elaboraram uma espécie de roteiro que verificava a titularidade do imóvel e a consistência dos documentos apresentados, o zoneamento e potencial construtivo da área, a existência de possíveis restrições para construção (questões ambientais, contaminação, ocupação da área, dentre outros). Encontrado algum terreno de interesse, o grupo visitava a área e buscava interlocução com os proprietários. A maioria das áreas estavam vinculadas a imobiliárias da região e nem sempre se dispunham a abrir negociação com o Movimento. Também nesse momento, buscávamos o apoio das assessorias técnicas que já haviam trabalhado com o movimento para avaliar o potencial da área para o desenvolvimento de projeto e verificar se o preço era compatível com o programa.

No primeiro momento, até 2008, na vigência do programa Crédito Solidário, os valores teto para a unidade habitacional eram bastante limitados ${ }^{68}$, sendo muito difícil conseguir propostas viáveis para o Movimento. Além do preço e localização, muitos terrenos tinham problemas com sua regularidade fiscal, necessitavam de retificação ou alguma outra providência. No entanto, o PCS só admitia a aquisição de áreas com nenhuma pendência, o que restringia muito o universo da busca.

No 1․․ semestre desse ano, já com apoio da Ambiente Arquitetura, o Movimento intensificou a busca por áreas. Cerca de 30 áreas foram analisadas e, por algumas das razões acima, descartadas. Dentre elas, foi identificada a área localizada na Vila Paulista, Cidade Tiradentes, apresentado por um captador de terrenos da região que nos levou à imobiliária que anunciava a área. Após as avaliações necessárias, o Movimento fez uma carta proposta que deveria ser apresentada pela imobiliária ao proprietário. O Movimento juntou um catálogo com sua experiência anterior na construção de empreendimentos habitacionais. Passado cerca de dois meses, sem resposta, a imobiliária informou ao Movimento que não tinha interesse na proposta. O Movimento chegou a pedir uma reunião com o proprietário, mas a imobiliária afirmou que este "não queria conversar com Sem Terra" (sic).

A Leste 1 seguiu buscando áreas, mas sem sucesso. Passados alguns meses, decidiu retomar a mesma área, mas agora tentando uma conversa direta com o proprietário, sem a intermediação da imobiliária. Após pesquisa na matrícula do terreno, o Movimento conseguiu o contato do proprietário que aceitou receber os

\footnotetext{
${ }^{68} \mathrm{Em} 2004$, o valor teto para a unidade habitacional do PCS era de $\mathrm{R} \$ 30.000,00$, chegando a $\mathrm{R} \$ 36.000,00 \mathrm{em}$ 2008, valores bem abaixo dos praticados no Programa MCMV Entidades, a partir de 2009.
} 
coordenadores e que informou que nunca havia recebido a proposta apresentada à imobiliária.

Figura 8 - Localização do terreno dos empreendimentos

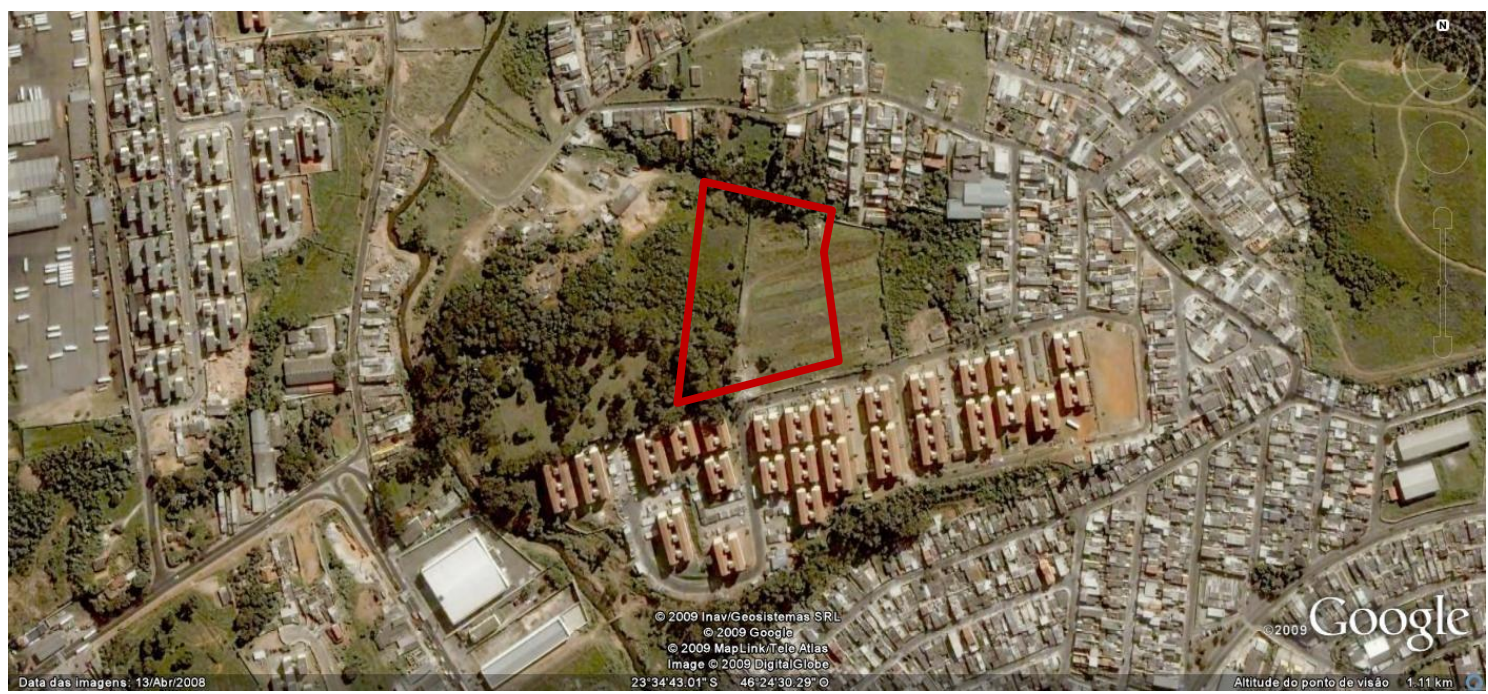

Fonte: Acervo do MST Leste 1

Nessa ocasião, o governo federal ainda discutia o lançamento do Programa Minha Casa Minha Vida e, com a crise econômica internacional, o mercado de imóveis vivia um momento de baixa. No entanto, o Movimento, dentro do Conselho Nacional das Cidades e em audiências com o governo federal, já vinha discutindo com o governo federal, o lançamento de um novo programa e por isso, buscava áreas para apresentar projeto.

O proprietário recebeu a coordenação do movimento e após algumas conversas, assinou a opção de compra e venda com o prazo de 15 meses, nas seguintes condições: nos primeiros 3 meses, o movimento faria os estudos necessários a identificar a viabilidade da área para um projeto de habitação popular e também a situação jurídica da área. Verificada a viabilidade da área, o Movimento deveria depositar o equivalente a $10 \%$ do valor do terreno, o que garantiria a opção de compra. Caso, no final do prazo, a compra não se realizasse, o Movimento perderia o valor pago. O Movimento apresentou aprovada a área para o grupo de famílias, que aprovou o prosseguimento das negociações. Mesmo com o risco que envolvia tal operação, a Leste 1 decidiu assinar a proposta, em dezembro de 2008 e pagou os $10 \%$, em março de 2009, o mesmo mês do lançamento do MCMV. 
Figura $9-1^{\text {a }}$ visita das famílias no terreno dos empreendimentos

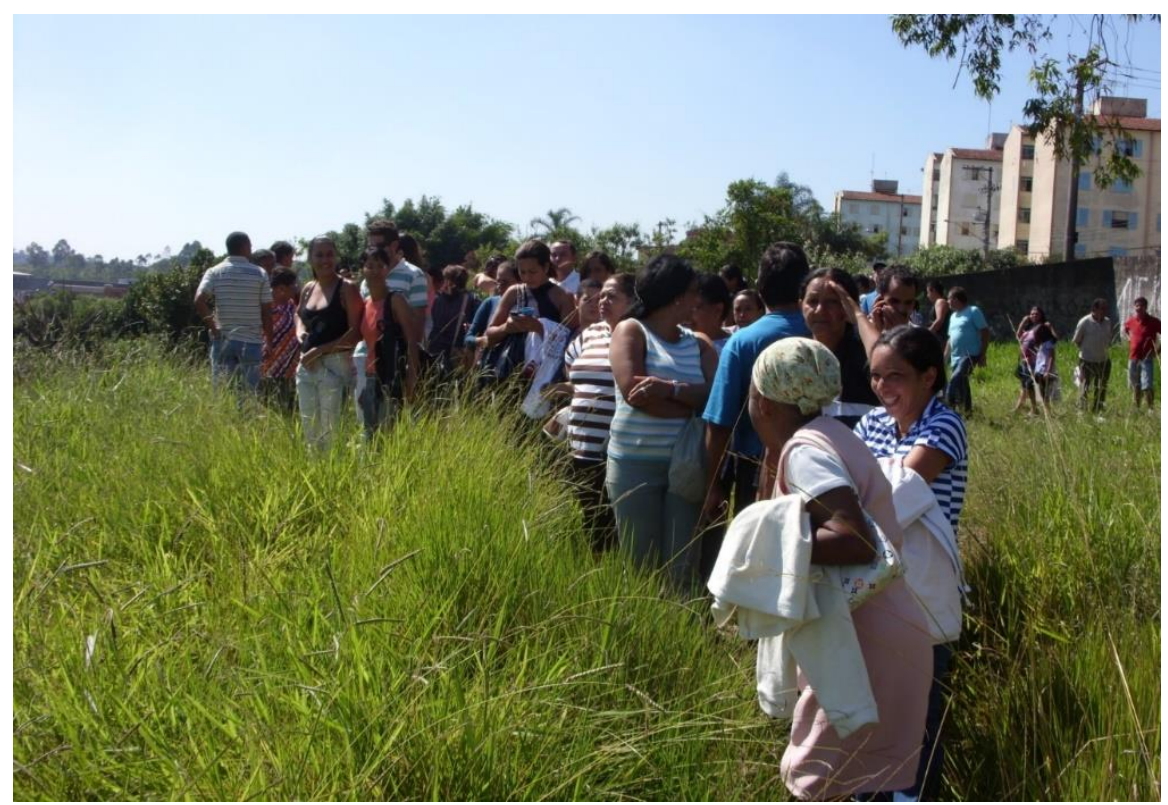

Fonte: Acervo do MST Leste 1

Em 2009, pouco antes do lançamento do programa Minha Casa Minha Vida, a UNMP apresentou uma proposta ao governo solicitando antecipação de parte dos recursos do empreendimento para a compra do terreno, projetos, topografia e sondagem e capacitação de grupo para autogestão na fase pré-obra. A próxima etapa seria a liberação de recursos para a construção de casas, o terreno ficaria em nome da associação até a liberação de recursos para construir as moradias a garantia real seria o terreno. Essa proposta iria garantir a área para as entidades e prazo para desenvolvimento e aprovação de projetos, já que com o aquecimento do mercado imobiliário seria muito difícil para as associações conseguirem opções de compra com o prazo necessário para o desenvolvimento do projeto e o licenciamento para só então efetivar a compra da área.

\subsection{Contrapartida financeira das famílias}

A estratégia aprovada para viabilizar a elaboração do projeto para apresentação no Programa Crédito Solidário ou em outro programa que viesse a sucede-lo, envolvia reunir os elementos técnicos necessários para a contratação no programa (de elaboração de projetos, licenciamento, aspectos jurídicos e de 
enquadramento das famílias participantes) em um prazo coerente com aquele obtido com a opção de compra do terreno e que evitasse retrabalhos ou perda de trabalho executado como havia ocorrido na proposta anterior.

Em suas experiências anteriores com a prefeitura e o governo estadual, a definição da área para construção - sempre de propriedade pública - e a elaboração de projetos aconteciam previamente. Dessa forma, o movimento não tinha praticamente que assumir nenhum custo financeiro nesse momento, já que a elaboração do projeto estava incluída no programa e era paga previamente. No PCS, a situação era inversa, conforme descrito anteriormente.

Dessa forma, era necessário ter uma estrutura dedicada do movimento, recursos para a assessoria técnica, para os laudos e estudos necessários (topografia, sondagem, laudos ambientais, entre outros), para a regularidade jurídica da proposta (avaliação dos documentos e certidões dos proprietários e da área) e para o trabalho social para a preparação do grupo. A avaliação do movimento é que não era mais possível, viabilizar esse conjunto de ações de forma voluntária e gratuita.

Para isso, o movimento definiu que, a partir desse momento, cada família integrante de um empreendimento deveria participar, além das atividades de gestão e de mutirão, com uma contrapartida financeira para custear as atividades necessárias à viabilização da contratação do empreendimento.

Esta decisão envolveu um longo debate e também algumas reações contrárias de lideranças do movimento. Até então, o movimento contava apenas com contribuição mensal no valor de duas passagens de ônibus municipal de cada participante para o custeio de sua estrutura e atividades. Havia tanto o temor que tal medida excluísse as famílias mais carentes quanto de que o movimento fosse identificado com uma organização mal intencionada, que enganava seus participantes.

Para esclarecer e dar segurança às famílias participantes, o movimento levou a proposta a todos os grupos de origem, fez reuniões de esclarecimento, antes da adesão de cada família à proposta.

"Para viabilizar esse projeto, precisamos organizar as famílias e constituir uma contrapartida. A assessoria técnica Ambiente está nos assessorando nesta proposta. 
1. A contrapartida será utilizada para:

- dar sinal na compra do terreno

- Pagar projeto arquitetônico e urbanístico

- pagar despesas administrativas do empreendimento

2. Cada família assinará um contrato individual com o Movimento, constando seus direitos e deveres. Inclusive a forma de ressarcimento em caso de desistência. Os pagamentos deverão ser feitos somente em banco.

3. Os valores e prazos para o pagamento da contrapartida são os seguintes:

\begin{tabular}{|l|c|l|}
\hline \multicolumn{1}{|c|}{ Opção 1 } & $\begin{array}{c}\text { Valor em } \\
\mathbf{R} \$\end{array}$ & \multicolumn{1}{c|}{ Prazo de pagamento } \\
\hline Parcela inicial & 150,00 & Na assinatura do contrato \\
\hline $2^{\text {a }}$ Parcela & 150,00 & 30 dias após \\
\hline $3^{\text {a. }}$ Parcela & 150,00 & 60 dias após \\
\hline $4^{\circ}$. Parcela & 150,00 & 90 dias após \\
\hline $\begin{array}{l}5^{\text {a }} \text {. a 19 } \\
\text { parcela }\end{array}$ & 50,00 & $\begin{array}{l}15 \text { Parcelas mensais, sempre no dia 15 } \\
\text { de cada mês }\end{array}$ \\
\hline Total & $\mathbf{1 . 3 5 0 , 0 0}$ & \\
\hline
\end{tabular}

4. A prestação de contas da contrapartida será mensal e feita pela coordenação da entidade e acompanhada por um grupo de representantes das famílias" ${ }^{\prime 6}$.

Além disso, foi elaborado pela assessoria jurídica do movimento, um contrato de adesão individual com as condições de participação, do enquadramento no programa, do pagamento da contrapartida e de sua restituição em caso de desistência ou exclusão do empreendimento.

Ainda assim, parte dos grupos inicialmente definiram por não participar do empreendimento, tendo revertido sua decisão quando o terreno já estava comprado.

A adesão das famílias se deu de forma bastante lenta, sendo necessário, além das reuniões citadas anteriormente, um atendimento individualizado feito por um membro da coordenação executiva que foi contratada para dedicar-se exclusivamente ao projeto.

Dessa forma, o movimento obteve os recursos necessários para fazer o estudo da área (ver descrição abaixo) e cumprir as demais exigências para a contratação. No entanto, quando da assinatura da opção de compra, foi exigido uma

\footnotetext{
${ }^{69}$ MST Leste 1, parte do Folder distribuído às famílias do movimento para orientação quanto à contrapartida financeira, 2009.
} 
caução de $10 \%$ do valor da área $(R \$ 111.000,00)$ e a contrapartida não tinha, até aquele momento reunido essa quantidade de recursos. O movimento conseguiu emprestar parte dos recursos necessários com uma entidade católica da região e de um projeto de fundo rotativo coma entidade internacional Habitat para a Humanidade, ambos com um prazo bastante grande para devolução. Essa estratégia foi aprovada na assembleia das famílias e efetivada, garantindo os recursos para a caução. Com os recursos da contrapartida, ambos compromissos financeiros foram saldados antes do prazo previsto.

\subsection{Compra do terreno}

Após o lançamento do MCMV Entidades, a UNMP seguiu em discussão com a SNH para a regulamentação do programa. A resolução № 141 foi publicada em 10 de junho de 2009 e a Instrução Normativa no 36, de 14 de julho de 2009. Somente após essas normativas é que o Programa efetivamente pôde iniciar.

Nesse sentido, em julho de 2009, a Leste 1, com a parceria com a assessoria técnica Ambiente, apresentou carta-consulta à Caixa Econômica Federal, dando início à tramitação oficial do empreendimento. Desde o primeiro momento, a proposta foi apresentada para a modalidade "aquisição de terreno e contratação de Assessoria Técnica" que, apesar de ser prevista nos normativos publicados, enfrentava grande resistência do Agente Operador do FDS, que não definia os procedimentos necessários para a contratação de tal modalidade.

Inicialmente foi apresentado uma ficha bastante sintética sobre o terreno, que foi seguida de uma vistoria da área de engenharia da Caixa em São Paulo, indicando que o terreno tinha as características necessárias para se enquadrar no programa (localização, infraestrutura externa, entre outros).

A partir daí, o Movimento e a Assessoria passaram a desenvolver o chamado "estudo de viabilidade" para a contratação no MCMV Entidades. Os empreendimentos José Maria Amaral e Florestan Fernandes foram os primeiros a serem contratados na modalidade "aquisição de terreno e contratação de Assessoria Técnica". A Caixa não possuía uma lista de documentos e peças técnicas necessárias e, inicialmente, exigiu, praticamente o mesmo conteúdo para a uma 
contratação de fase de obras. Isso foi motivo de muitas divergências entre os movimentos e a Caixa.

Figura 10 - Mobilização na Caixa para a implementação da Compra Antecipada

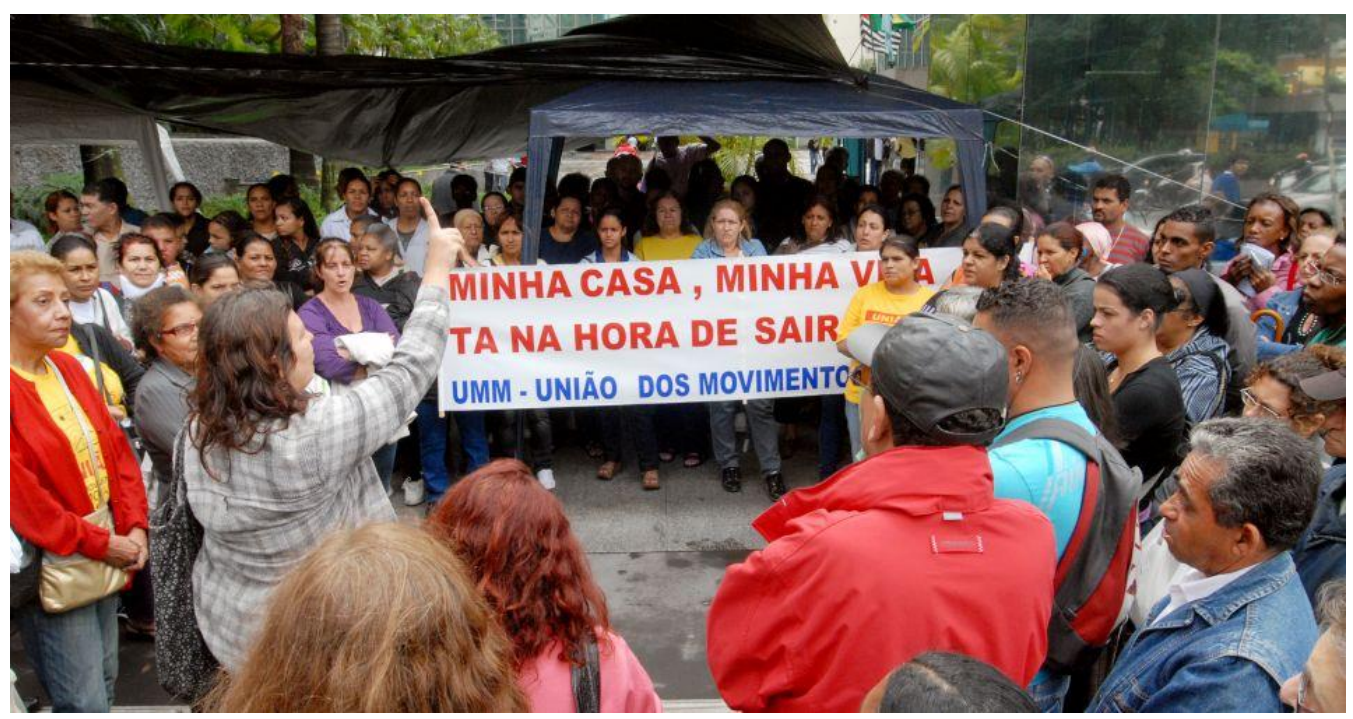

Fonte: Acervo do MST Leste 1

Os movimentos defendiam que a Caixa deveria exigir o mínimo necessário para considerar que o projeto seria "aprovável", ainda que não estivesse aprovado. No final do processo, definiu-se que um "estudo de massa" seria suficiente para essa definição, com um número de unidades previsto, embora os projetos de JMA e FF já estivessem fase bem mais avançada. Além disso, foi exigido topografia, sondagem e diretrizes de viabilidade de uso e ocupação do solo, das concessionárias de água, esgoto e energia para o que se chamaria de "compra antecipada". Também foram solicitadas informações acerca da infraestrutura existente no entorno da área e da localização de equipamentos religiosos; equipamentos sociais e culturais; serviços; equipamentos de educação; equipamentos de saúde; meios de transporte; equipamentos de lazer e comércio descritos em mapa.

Ao consultar a Prefeitura sobre a necessidade de uma "diretriz de viabilidade" da proposta, a assessoria técnica recebeu a resposta de que esta somente se manifestaria por meio da aprovação do projeto e que não existiria tal diretriz. Foi fornecido apenas os parâmetros de uso e ocupação do solo, disponível em legislação, que está reproduzido em figura abaixo. O agente financeiro local alegava que tal informação era insuficiente e foi um dos itens de intenso debate. Por fim, a 
Caixa aceitou o documento junto com uma declaração da assessoria técnica de que a proposta atendia aos parâmetros da legislação municipal e era passível de aprovação. Anos após este fato, devido a novos pedidos de outras entidades interessadas na modalidade de "compra antecipada", a SMDU desenvolveu um padrão para fornecer uma declaração que atendesse à exigência do Agente Financeiro.

Figura 11 - Parâmetros fornecidos pela Prefeitura para o terreno

\begin{tabular}{|c|c|c|c|c|c|c|c|c|c|c|c|c|}
\hline$N^{\circ}$ CONTRIBUINTE & $\operatorname{IaCRA}$ & 238 & 580 & 2 & -8 & SUBPRE & EFEITURA & 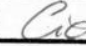 & cle & 11 & lente; & \\
\hline \multirow{3}{*}{$\begin{array}{l}\text { CLASSIFICAÇÃO } \\
\text { DE VIA }\end{array}$} & \multirow{3}{*}{ ZONA DE USO } & \multicolumn{3}{|c|}{ COEFICIENTE DE APROVETIAMENTO } & \multicolumn{5}{|c|}{ CARACTERISTICAS DE APROVEITIAMENTO E OCUPACĀ̄o } & \multicolumn{3}{|c|}{ RECUOS MiNIMOS (m) } \\
\hline & & \multirow{2}{*}{ мімммо } & \multirow{2}{*}{ Básico } & \multirow{2}{*}{ MáXIMO } & \multirow{2}{*}{$\begin{array}{c}\text { TAXA DE } \\
\text { OCUPACAOO } \\
\text { MAXXIMA }\end{array}$} & \multirow{2}{*}{$\begin{array}{c}\text { TAXADE } \\
\text { PERMEABLIIDADE } \\
\text { MiNNAMA } \\
\end{array}$} & \multirow{2}{*}{$\begin{array}{c}\begin{array}{c}\text { Lote Minmuo } \\
\left(\mathrm{m}_{2}\right)\end{array} \\
\end{array}$} & \multirow{2}{*}{$\begin{array}{c}\text { ERENTE } \\
\text { MiNiMA (m) }\end{array}$} & \multirow{2}{*}{\begin{tabular}{|c|} 
GABARITO DE \\
ALtTrRA \\
MâXXMO (m) \\
\end{tabular}} & \multirow{2}{*}{ FRENTE } & \multicolumn{2}{|c|}{ FUNDOS ELATERAIS } \\
\hline & & & & & & & & & & & $\begin{array}{l}\text { ALTURA A EDEFF, MENOR } \\
\text { OU IGUAL } 6.00 \mathrm{~m}\end{array}$ & \begin{tabular}{|l} 
ALTURA DA EDIF. \\
MAIOR $6,00 \mathrm{~m}$ \\
\end{tabular} \\
\hline & ZEIS 1-2144 & 0,2 & $\$, 0$ & 2.5 & $\begin{array}{l}0,5 \\
1 a) \\
\end{array}$ & 0,15 & 125 & 5,0 & $\begin{array}{c}\text { sem } \\
\text { linite } \\
*\end{array}$ & $\begin{array}{l}5,0 \\
(\alpha)\end{array}$ & now evigido & $\begin{array}{c}\frac{H-6}{10} \\
m i n-3 m\end{array}$ \\
\hline \multicolumn{13}{|c|}{ 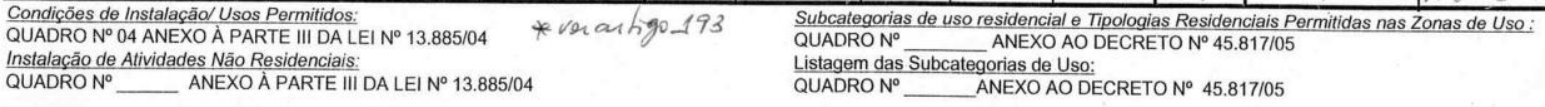 } \\
\hline \multicolumn{8}{|c|}{ http://sempla.prefeitura.sp.gov.br/urb_zon.php } & & & & & \\
\hline
\end{tabular}

Fonte: Acervo do MST Leste 1

Um dos temas de debate para a compra da área e contratação do projeto foi a proposta de verticalização apresentada pelo Movimento, com edifícios com 11 pavimento e, por consequência, com elevadores. O Movimento apresentou a proposta para a Caixa após extensa discussão com o grupo de famílias e a assessoria, que trouxe elementos sobre o melhor aproveitamento do terreno e de sua topografia, a destinação de áreas para outros usos e o custo do metro quadrado. Também foi considerado o custo de manutenção dos elevadores na fase de pós-ocupação, a partir de orçamento feitos com diversas empresas do mercado. No entanto, houve resistência do governo, utilizando tanto argumentos em relação ao custo para famílias de baixa renda, quanto outros de caráter estritamente preconceituosos, como de que "famílias de baixa renda não saberiam utilizar ou quebrariam o equipamento"70. Essa e inúmeras outras questões não puderam ser resolvidas pela estrita observância dos normativos e foram objeto do que se costumou chamar de "excepcionalizações", aprovadas pela Matriz da Caixa ou pela Secretaria Nacional de Habitação.

Um outro tem que merece destaque neste relato foi em relação à questão levantada pelo agente financeiro se a área era ou não considerada "urbana",

\footnotetext{
${ }^{70}$ Frase de técnico da Caixa em São Paulo em reunião com a Leste 1.
} 
requisito do programa. O Plano Diretor de São Paulo desde 2002, extinguiu a zona rural de todo o território da cidade e demarcou essa área como Zona Especial de Interesse Social 1 - ZEIS. Portanto, não haveria dúvida sobre a área ser "urbana”, já que essa condição deve ser definida pelo Plano Diretor e ou Lei de Uso Ocupação do Solo, ambos de competência municipal. No entanto, a Prefeitura de São Paulo, até aquela data, não havia lançado a área no cadastro municipal, o que permitiria à municipalidade cobrar o IPTU. A área seguia, enquanto a municipalidade não o fizesse, pagando o imposto sobre a propriedade territorial rural (ITR). Tal fato foi alegado pela Caixa como impeditivo para a compra da área, pois entendia que o pagamento de ITR significava que se tratava de zona rural, embora essa figura não constasse na legislação municipal. O Movimento fez um parecer jurídico questionando tal posição, mas a área responsável não o aceitou. Foi preciso uma grande mobilização, que ocorreu de forma simultânea em São Paulo e Brasília, e uma audiência com o presidente da Caixa, para que tal situação fosse afastada e a compra do terreno fosse aprovada. Mesmo assim, o questionamento perdurou durante todo o período de projetos. O Movimento requereu o lançamento do IPTU da área, o que levou mais de 2 anos, e depois, conquistou a isenção.

Até o mês de fevereiro de 2010, a modalidade não havia sido regulamentada internamente pela Caixa. Cabe dizer que, além das normas publicadas pelo Conselho Curador do FDS (resoluções) e Ministério das Cidades (instruções normativas) que são públicas, a caixa possui os seus manuais operacionais ${ }^{71}$ que, por muitas vezes, extrapolam, as competências e definições expressas nas normas citadas anteriormente e que eram de uso privativo dos funcionários da Caixa. Como a opção de compra assinada com os proprietários venceria em março de 2010, novamente o movimento se mobilizou para pressionar o governo. Em reunião na Caixa em São Paulo, os proprietários concordaram em aditar a proposta em 1 mês e que não mais prorrogariam caso não houvesse a contratação. Naquele abril, finalmente foram concluídos os trâmites e, em 26 de abril de 2010, foi celebrado o contrato. Os mutirões Florestan Fernandes e José Maria Amaral foram os primeiros a serem contratados nessa modalidade em todo o país.

\footnotetext{
${ }^{71}$ Os movimentos costumaram a chamar esses normativos de "manual secreto da Caixa". Na prática eram dois documentos $(\mathrm{HH} 155$ e HH 164) elaborados pelas áreas relacionadas ao programa.
} 
Figura 12 - Atividade de celebração da compra da área e contratação do empreendimento

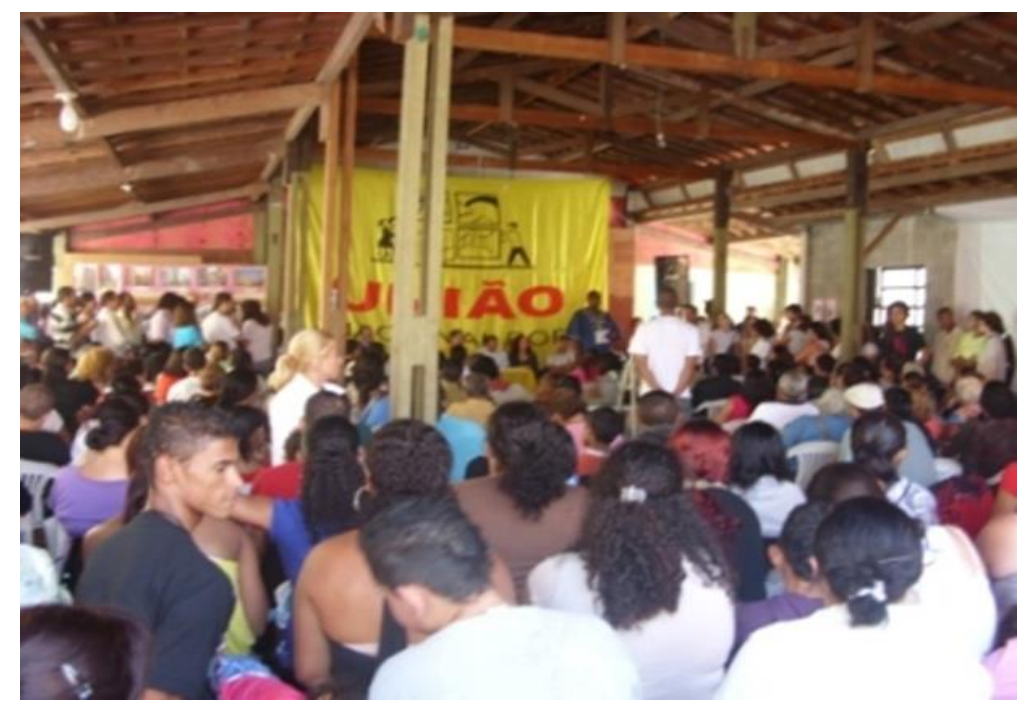

Fonte: Acervo do MST Leste 1

\subsection{Elaboração do projeto}

Com o terreno comprado, passamos à fase de elaboração e licenciamento de projeto. Para a compra da área, a assessoria técnica havia desenvolvido um projeto preliminar com algumas características que não poderiam ser mudadas: o mínimo de 396 unidades, divididas em 2 condomínios independentes. A proposta inicial consistia em 2 blocos em constituídos por 2 lâminas em cada condomínio. Havia também, na matrícula, a descrição de um córrego no fundo do terreno. Embora houvesse dúvida se era um córrego ou uma vala de esgoto clandestino, também foram deixados 30 metros exigidos pela legislação ambiental.

No entanto, depois do terreno comprado, tanto a área de engenharia da Caixa quanto as famílias fizeram alguns questionamentos sobre a proposta inicialmente apresentada. 
Figuras 13 e 14 - Implantação proposta para aquisição da área

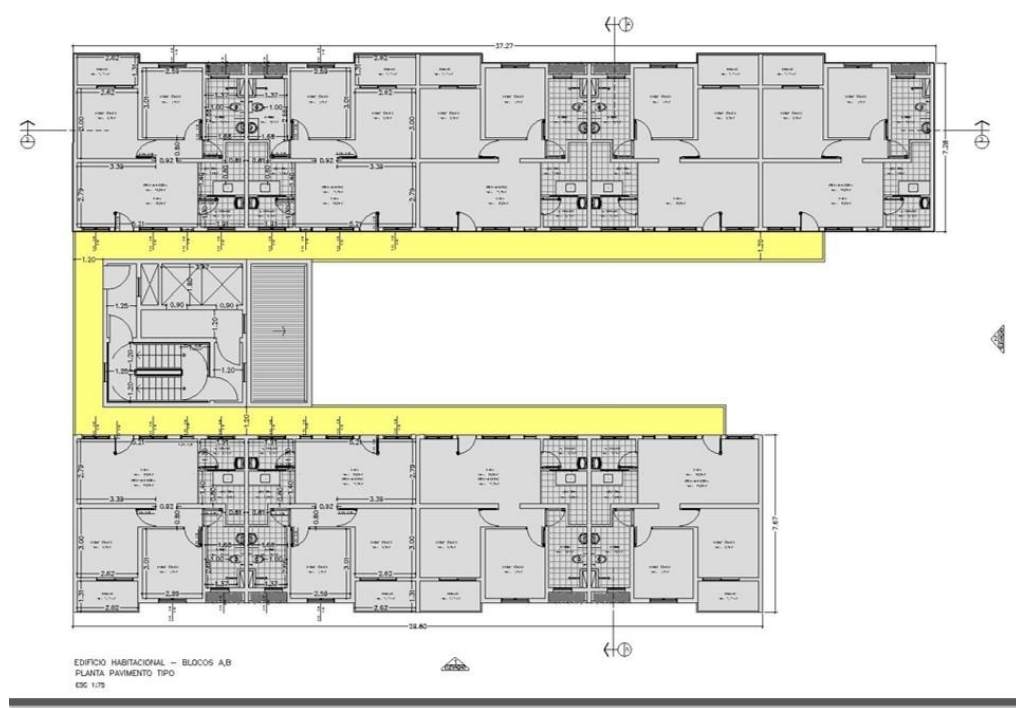

O EDIFÍCIO PAVIMENTO TIPO

LOTE 01 - 2 EDIFÍCIOS COM 11 PAVIMENTOS - TOTAL DE 198 UNIDADES LOTE 02 - 2 EDIFÍCIOS COM 11 PAVIMENTOS - TOTAL DE 198 UNIDADES

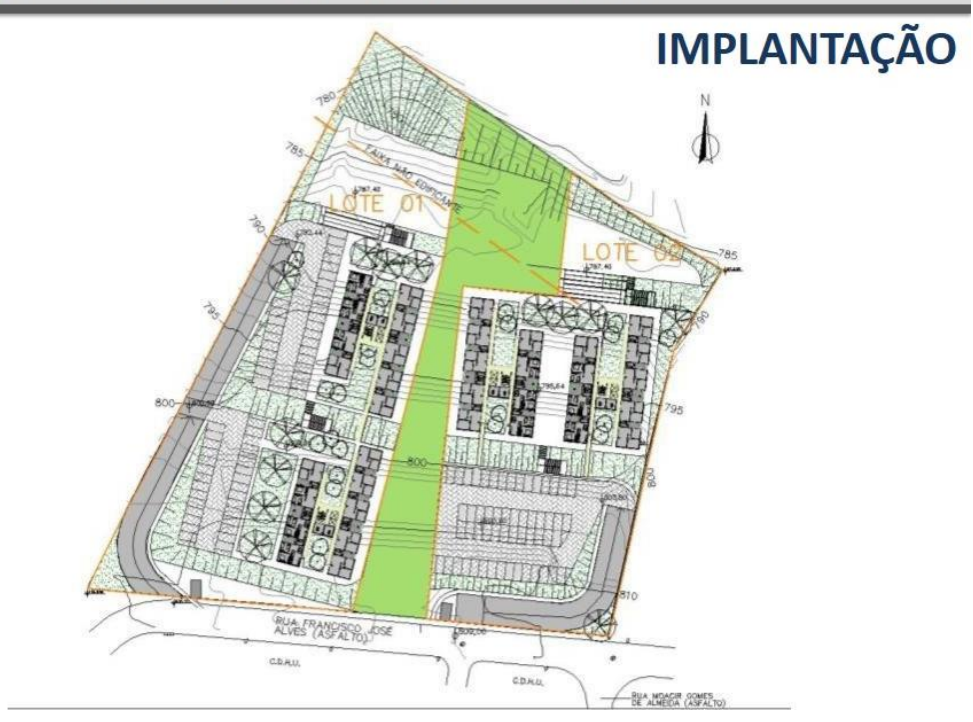

Fonte: Ambiente Arquitetura

Como a área tinha uma patamarização executada anteriormente e da qual não se tinha projeto ou maiores informações, a área de engenharia da Caixa sugeriu que fosse apresentada uma nova implantação que aproveitasse tal perfil do terreno e diminuísse a necessidade de movimentação de terra.

As famílias mutirantes, por outro lado, questionaram o formato de lâmina para os edifícios, afirmando que a proposta prejudicava a privacidade das famílias com unidades no meio da lâmina. Outro debate ocorreu por conta da localização da 
varanda, onde parte das famílias propunham a varanda na sala e parte em um dos quartos. A varanda era um ponto "inegociável" na elaboração do projeto, visto como um item que agregaria qualidade ao apartamento.

Figura 15 - Assembleia para a discussão de projeto

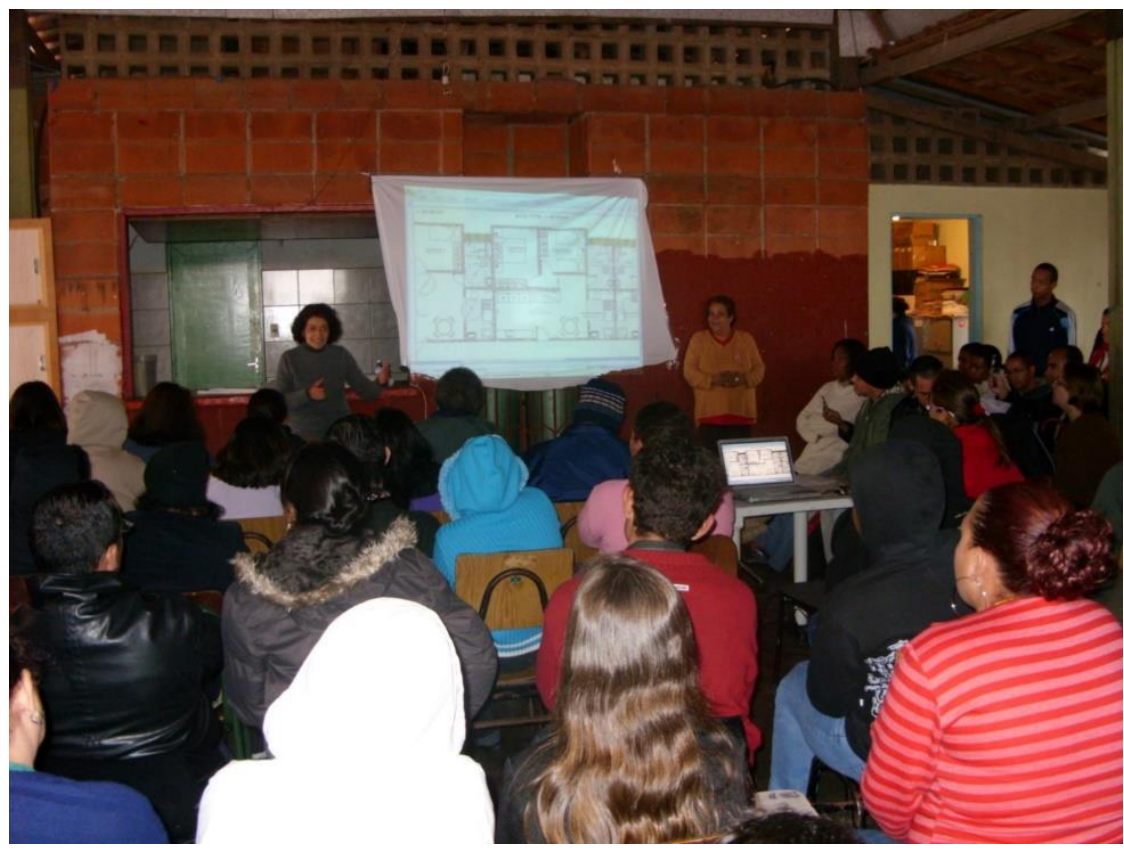

Fonte: Acervo do MST Leste 1

Nesse processo de discussão, a assessoria apresentou uma proposta com mudanças no conceito do conjunto. No lugar das lâminas, foram propostos blocos com 2 torres, conectadas por passarelas, distribuídas ao longo do terreno. Além disso, foi proposto um viário que serviria também para assegurar a acessibilidade, tendo em vista a acentuada declividade do terreno.

Também foram apresentadas pela assessoria algumas soluções, que se não podemos chamar de inovadoras, não são comuns com os projetos habitacionais populares, como a utilização de elementos vazados na circulação entre os apartamentos e na lavanderia e nas floreiras a serem construídas nas varandas. Para a discussão dessas e outras propostas, a assessoria trouxe referências de edifícios residenciais de diversos segmentos e localidades, ampliando o repertório das famílias para a tomada de decisão. 
Figura 16 - Implantação Final aprovada

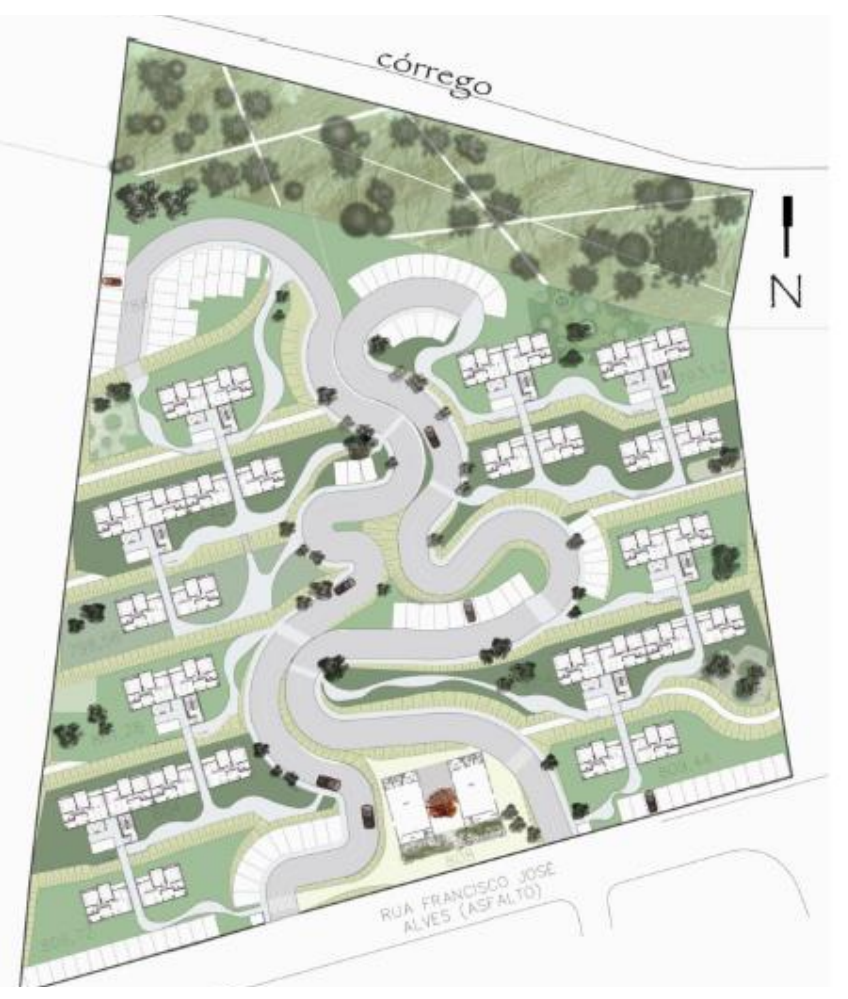

Fonte: Ambiente Arquitetura

Outra preocupação foi fazer com que o conjunto não significasse uma quebra abrupta do padrão do entorno. Os empreendimentos ficam em frente ao um antigo conjunto da $\mathrm{CDHU}$, com 5 pavimentos. $\mathrm{O}$ projeto aprovado tem menos pavimentos nos blocos localizados mais perto da rua e na parte mais alta do terreno e mais pavimentos no fundo, na parte mais baixa, chegando a 15 pavimentos.

Figura 17 - Corte esquemático

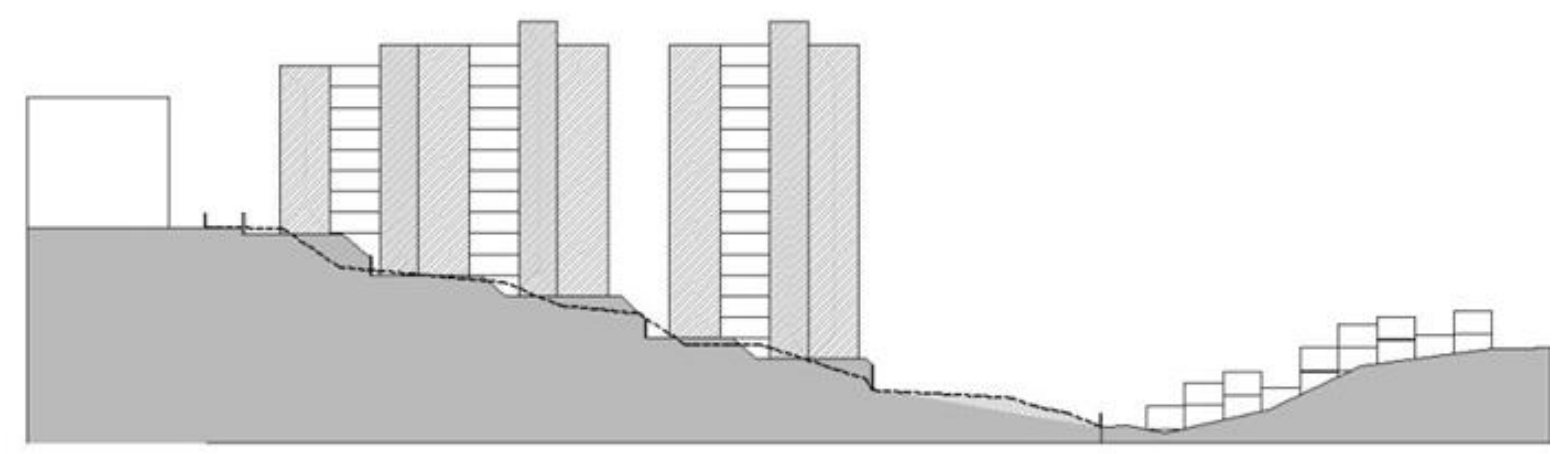

Fonte: Ambiente Arquitetura 
Uma contribuição da coordenação da Leste 1 para o projeto foi a forma e localização do Centro comunitário. A Leste 1 já tinha experiência em outros empreendimentos sobre as dificuldades de integrar o conjunto ao bairro e também do risco do centro comunitário permanecer sem atividades ou como mero "salão de festas". Nesse sentido, foi discutido com as famílias e com a assessoria a proposta de um equipamento que comportasse uma diversidade de atividades, pudesse receber projetos e convênios públicos para atendimento social e, para isso, deveria ficar de frente para a rua, com acesso independente da parte residencial.

Ainda que se tratasse de 2 condomínios, desde as primeiras discussões, foi trabalhada a ideia de não haver divisão física entre eles na área residencial nem no centro comunitário.

Figura 18 - Atividade de discussão de projeto

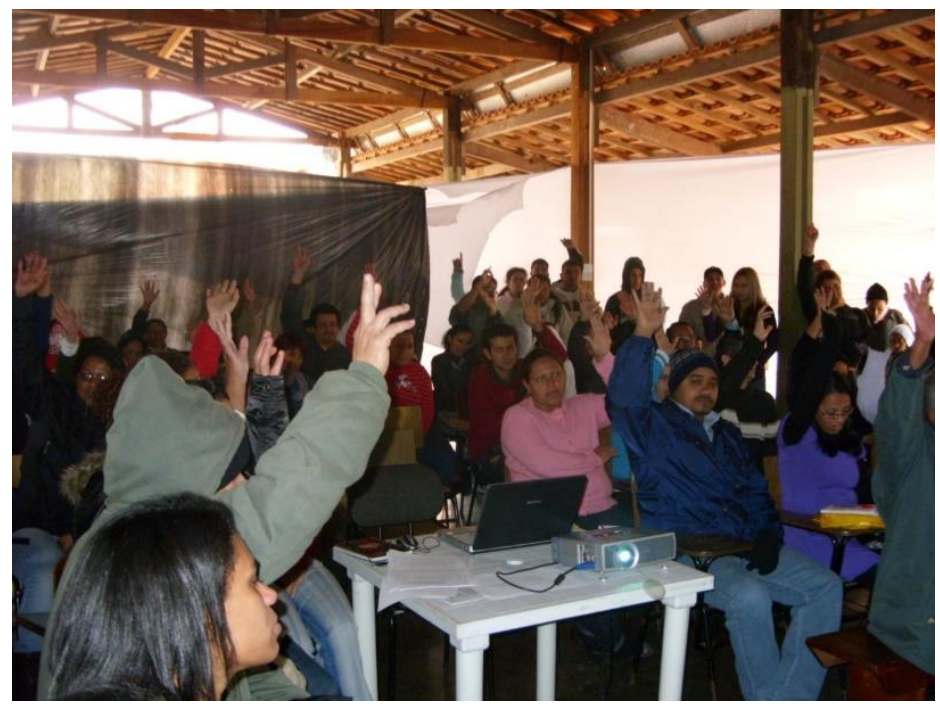

Fonte: Acervo do MST Leste 1

\subsection{Licenciamento do projeto}

Passada a compra do terreno e a aprovação do projeto junto às famílias, passou-se à fase de aprovação. Para o movimento, o processo de aprovação nos trâmites regulares do município era algo novo, pois os empreendimentos anteriormente construídos, seja com financiando municipal ou estadual, tinham sido aprovados apenas junto aos órgãos responsáveis pelo financiamento, como COHAB ou $\mathrm{CDHU}$ e regularizados depois da construção e ocupação. O MCMV Entidades trazia a necessidade do licenciamento prévio tanto do parcelamento do solo, quanto 
da edificação, bem como a aprovação junto às concessionárias de água, esgoto, energia, prevenção de incêndio e gás. Para o programa, o objetivo era que, ao final da obra fosse obtido o auto de conclusão de obra, conhecido na linguagem popular como "Habite-se" e também a averbação do condomínio junto ao Registro de Imóveis, a fim de obter uma matrícula individualizada para cada família, passível de alienação fiduciária junto ao Agente Operador do FDS.

Além disso, era preciso atender à toda a legislação incidente (plano diretor, lei de uso e ocupação do solo, decreto de habitação de interesse social, entre outros) e, ao mesmo tempo, atender às especificações mínimas previstas no Programa MCMV Entidades. Isso levava a um processo de dupla aprovação, onde a exigência de uma parte poderia comprometer a aprovação em outra. As especificações do MCMV também tiveram mudança da etapa 1 para a segunda etapa do programa, sendo esta mais exigente. Como a $1^{\underline{a}}$ fase dos empreendimentos Florestan Fernandes e José Maria Amaral foi contratada durante a etapa 1 do programa, o movimento poderia optar por atender as exigências já previstas ou ás novas. No entanto, mesmo que isso tenha significado o retrabalho de algumas peças técnicas, o movimento, a coordenação e a assessoria técnica definiram pela adaptação do projeto para a segunda etapa do programa, o que também significou um valor maior por unidade habitacional (de $R \$ 56.000,00$ para $R \$ 76.000,00$ ). Cumpre dizer, que os projetos apresentados sempre tiveram índices maiores do que os mínimos exigidos pelo programa. Para ilustrar essa questão, na etapa 1, o programa exigia o mínimo de $39 \mathrm{~m} 2$ de área útil da unidade habitacional e $42 \mathrm{~m} 2$ na etapa 2: os apartamentos dos empreendimentos estudado têm $56 \mathrm{~m}^{72}$. Apenas a questão da acessibilidade universal (todas as unidades deveriam ser adaptáveis) exigiu mudanças mais significativas no projeto inicial.

A Prefeitura de São Paulo levou exatamente 1 ano, 9 meses e 5 dias para licenciar os projetos dos empreendimentos Florestan Fernandes e José Maria Amaral, durante a gestão do prefeito Gilberto Kassab (2006 a 2012). A tramitação iniciou-se em janeiro de 2010 e somente terminou em novembro de 2011. Apesar do longo tempo decorrido, o processo administrativo de aprovação, no Departamento de Aprovação de Edificações (APROV), que à época se encontrava na Secretaria

\footnotetext{
${ }^{72}$ A Revista da Autogestão indicou que as unidades habitacionais dos empreendimentos produzidos por autogestão estudados têm, em média, 52,34 m2.
} 
Municipal de Habitação, teve apenas um "comunique-se" tendo ficado sem nenhuma análise por grande parte desse tempo.

Houve bastante insatisfação por parte das famílias em relação ao tempo decorrido após a compra do terreno. Os trâmites de aprovação não faziam parte do repertorio do movimento e muito menos dos mutirantes. Nas assembleias, eram prestadas as informações dos passos dados e das etapas ainda necessárias. Para isso foram desenvolvidas algumas ilustrações (Figuras 19 e 20) e os tempos despendidos em cada órgão.

Figura 19 - Representação da tramitação do processo de aprovação dos empreendimentos

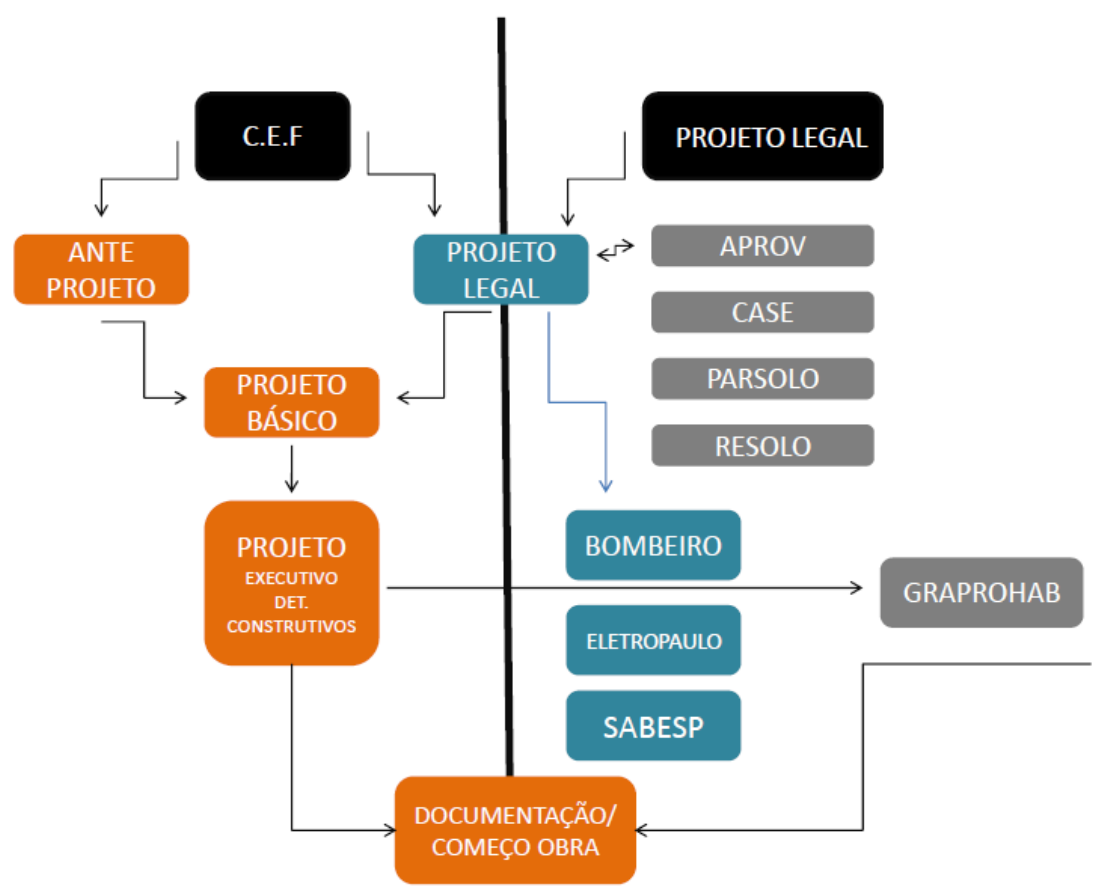

Fonte: Ambiente Arquitetura, 2010 


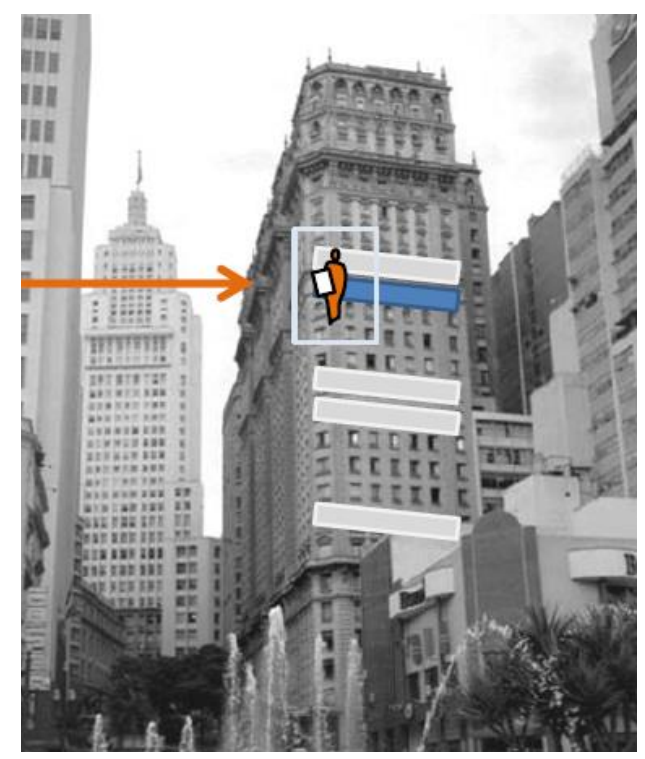

Fonte: Ambiente Arquitetura, 2010

Tal processo levou o movimento a acompanhar a aprovação mais de perto e se apropriar dos trâmites, bem como pressionar as autoridades relacionadas. No $2^{\circ}$. Semestre de 2011, uma mobilização da UMM na Sehab tinha, dentre as suas reivindicações, a prioridade para a aprovação para os empreendimentos de HIS. Mobilizações junto ao $\mathrm{CMH}$ também foram feitas antes da obtenção da aprovação do projeto em APROV.

Os empreendimentos obtiveram a dispensa de análise pelo GRAPROHAB Grupo de Análise e Aprovação de Projetos Habitacionais do Estado de São Paulo, devido a tratar-se de um desdobro e de cada um dos condomínios não ultrapassar o número 300 unidades habitacionais ${ }^{73}$. Essa dispensa economizou tempo para a conclusão do licenciamento, bem como a elaboração de novas peças técnicas.

Após a conclusão do licenciamento na Prefeitura, o movimento ainda buscou as aprovações dos projetos de energia, água e esgoto e de prevenção de incêndios.

No Corpo de Bombeiros, os projetos de prevenção de incêndios precisaram ser protocolados separadamente, conforme o regramento do órgão. Fato curioso foi que, apesar de se tratar de projetos idênticos, cada um deles foi distribuído a um técnico diferente, sendo que um aprovou o projeto sem ressalvas e o outro fez uma

\footnotetext{
${ }^{73}$ Artigo 5ํ do Decreto Estadual № 52.053 de 13/08/2007
} 
série de exigências, o que fez que a assessoria apresentasse algumas alterações e que, fez com que cada empreendimento tivesse itens distintos.

Ainda nessa fase, foram elaborados os projetos executivos e complementares de ambos os conjuntos e submetidos à Caixa. Com os projetos aprovados, coube à assessoria técnica elaborar o orçamento total da obra, dentro dos limites previstos para o programa, somado a um aporte de $R \$ 20.000,00$ por unidade conquistado junto à Secretaria Estadual de Habitação.

Os aportes foram conquistados pelas mobilizações dos movimentos junto ao governo estadual de São Paulo ainda no Programa Crédito Solidário (2004-2008) e seguiram no MCMV Entidades. Posteriormente, o governo criou a Casa Paulista e estendeu a possibilidade de aporte para toda a faixa 1 (FAR, PNHR e FDS), com o argumento de que os custos da habitação eram maiores no Estado de São Paulo e que os valores definidos pelo Governo Federal eram insuficientes. Os empreendimentos Florestan Fernandes e José Maria Amaral foram um dos primeiros contratos do MCMV Entidades a serem complementados com recursos estaduais, ainda em 2010, logo após a compra do terreno.

Além dos valores do FDS e da Secretaria Estadual de Habitação, também foram computados os aportes financeiros feitos pelas famílias e as horas de mão de obra mutirante, convertida em valores financeiros, com base na quantidade de horas de trabalho de ajudante de obras a serem realizadas em mutirão por cada família.

Ainda era preciso somar os recursos para a extensão da rede de água até a entrada do condomínio, considerada uma "infraestrutura não incidente" por estar fora do perímetro do terreno e não ser financiada pelo programa. Nesse sentido, as famílias tiveram que aportar $R \$ 51.842,91$ ( $R \$ 130,91$ por família) para esse componente.

No momento da contratação da fase obras, o movimento e a assessoria avaliaram não ser necessário o pedido de aporte municipal, já que, com a mudança do MCMV 1 para o MCMV 2 e o aporte estadual, os valores eram suficientes. A Prefeitura de São Paulo somente veio a aportar recursos em 2017, como veremos à frente. 
Figura 21 - Orçamento dos empreendimentos após aportes
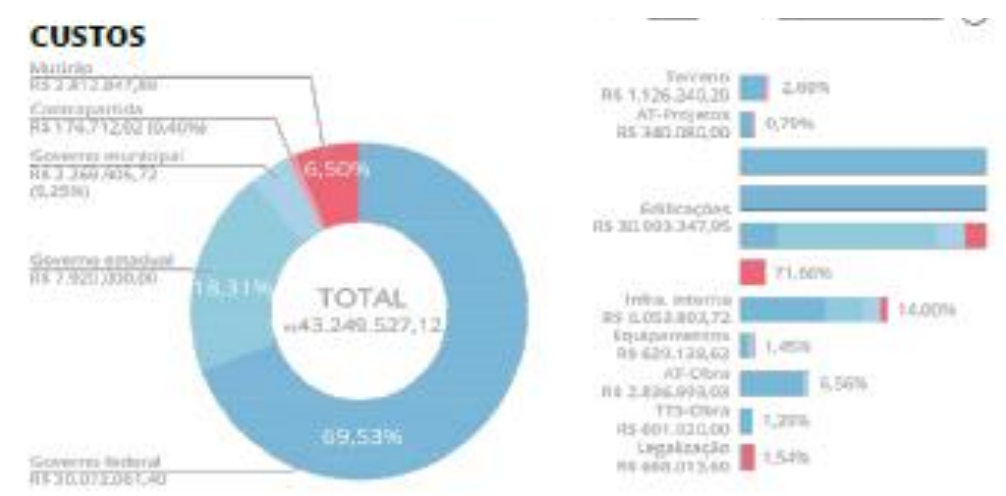

Fonte: UNMP, Revista da Autogestão, 2019

Ao mesmo tempo que eram feitas as análises de engenharia, a equipe de Trabalho Social elaborou o projeto de Trabalho Social para a etapa de obras e de pós ocupação. A equipe percebeu que o normativo de Trabalho Social do Ministério das Cidades $^{74}$ e 0 Cadernos de Orientações da Caixa não se adequavam a processos autogestionários, pois não incluíam os processos de gestão coletiva da produção habitacional. Nesse sentido, o projeto continha duas partes: aquela exigida pelos normativos do programa e outra, com as questões relacionadas ao funcionamento da autogestão.

\subsection{Contratação da fase de obras}

Vencidas as aprovações de engenharia e social, os empreendimentos seguiram para a etapa de contratação da fase de obras e novas questões se apresentaram.

A principal delas disse respeito ao formato previsto pela primeira regulamentação da "compra antecipada". Na Resolução do CCFDS n 143, de 26 de novembro de 2009, a Entidade Organizadora seria responsável pelo contrato desde a compra do terreno até a contratação da fase de obras. Nesse momento, segundo o normativo e com projeto aprovado, seria possível fazer a instituição do condomínio

\footnotetext{
${ }_{74}$ O Trabalho Social no MCMV Entidades estava regulado por meio da instrução normativa ํㅡ 45, de 8 de novembro de 2012
} 
e contratar a fase de obras com cada um dos beneficiários finais, à semelhança do que era feito no Programa Crédito Solidário e também nos empreendimentos de fase única do MCMV Entidades.

O MST Leste 1, junto com a UNMP, questionou o formato com diversos argumentos. O primeiro é que a incorporação imobiliária não seria o instituto jurídico apropriado para uma produção coletiva, pois é um instrumento de mercado, utilizado para vender unidades habitacionais a serem produzidas futuramente. Além disso, a designação da unidade final à família mutirante não observa as inúmeras mudanças que ocorrem durante o período de obra, fazendo com que a qualquer mudança no grupo familiar ou desistência do empreendimento necessitasse de um distrato no contrato de financiamento e registro tanto do distrato, quanto da entrada de nova família, gerando custos não previstos no orçamento. Soma-se a isso o fato que uma das estratégias do mutirão e da autogestão é que todos constroem a moradia de todos e somente no final, aferida a participação, a unidade específica é escolhida pela família, conforme a hierarquização obtida. Outro argumento focava no papel do movimento durante o período de obras, pois toda a produção seria feita de forma coletiva e não apenas uma soma de financiamentos individuais.

Novamente houve tensão entre o entendimento do gestor do programa e os movimentos. Após algumas reuniões e mobilizações, inclusive um acampamento no Ministério das Cidades, a Caixa apresentou uma alternativa que seria a continuidade do contrato em nome da entidade até o final da obra ${ }^{75}$, com a averbação do condomínio nesse momento, com a constituição de matrículas individuais para cada unidade habitacional e consequente contrato individual de financiamento e alienação fiduciária da unidade ao FDS.

A mudança da Resolução beneficiou todos os empreendimentos que haviam sido contratados na modalidade "compra antecipada" e marcou uma mudança de perspectiva do programa, onde mesmo os empreendimentos de fase única contratação direta da fase de obras - passaram a ser feitos com a entidade organizadora para serem individualizados ao final da obra.

\footnotetext{
${ }^{75}$ Resolução do CCFDS no 183 , de 10 de novembro de 2011
} 
Figuras 22 e 23 - Ocupação do Ministério das Cidades, 2013
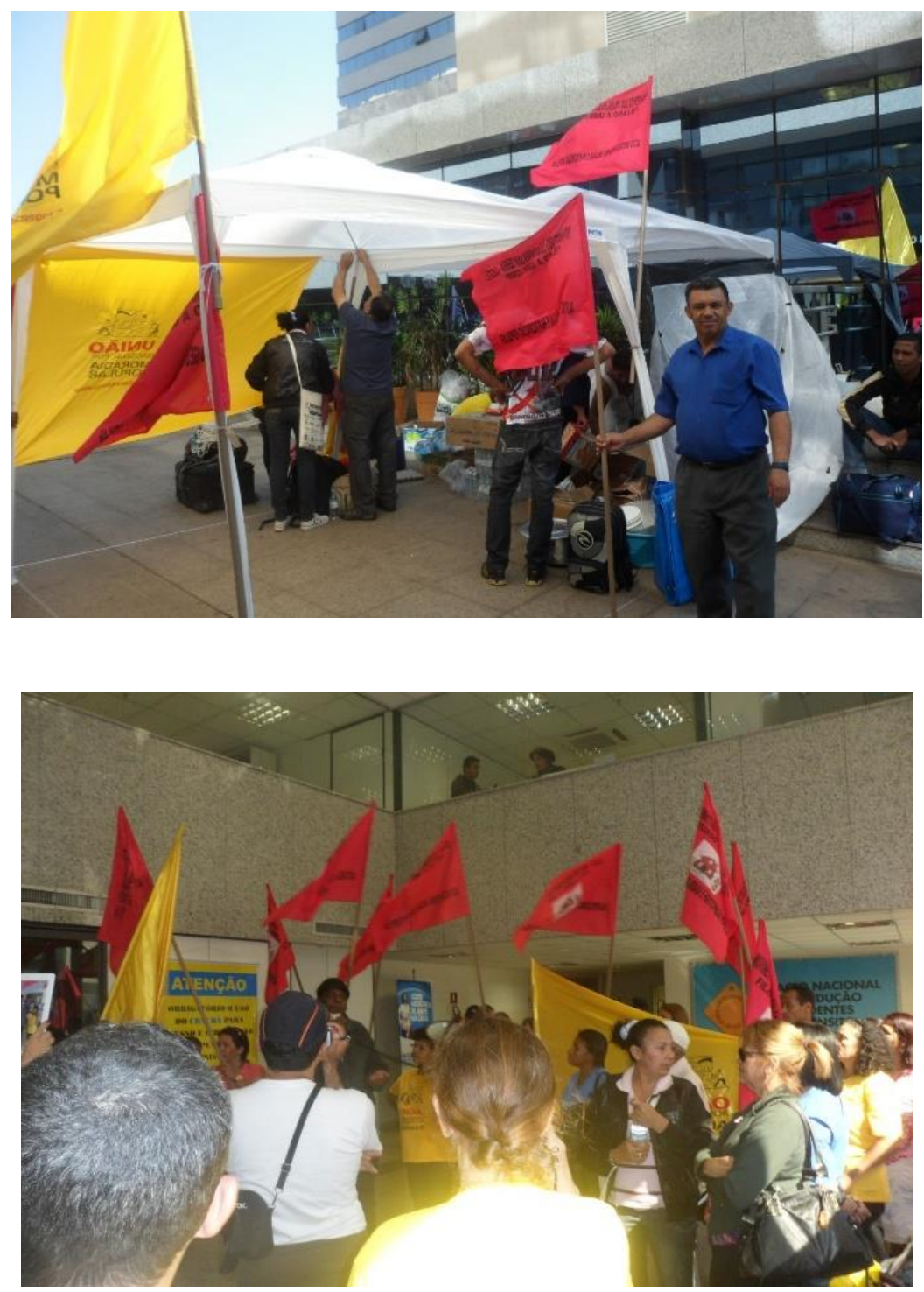

Fonte: Acervo MST Leste 1

Finalmente, o contrato da fase de obras foi assinado em março de 2013, em nome da associação, acompanhado de um Termo de Compromisso com cada uma das famílias participantes, já enquadradas pelo agente financeiro nas regras do programa. No entanto, o alvará de movimentação de terra só foi emitido em outubro de 2013, pela Prefeitura de São Paulo, quando foi possível iniciar efetivamente a execução da obra, sete meses após a data de vigência do contrato. 


\subsection{Regulamento de obras}

Ainda durante a fase de projeto, o grupo de famílias discutiu e aprovou o seu "Regulamento de Obras e Participação". Este documento é um conjunto de normas internas com as obrigações, comportamentos desejáveis e intolerados, orientações e sistema de reconhecimento e de penalizações, válido para todo o período da obra. Trata-se de uma pactuação entre todos os agentes envolvidos - mutirantes, coordenação do movimento, assessoria técnica - sobre a forma de organizar a ação em comum e distribuir as responsabilidades do processo. O Regulamento também trazia uma conceituação sobre o processo de mutirão com autogestão:

Entende-se o sistema de administração por AUTOGESTÃO com MUTIRÃO parcial como sendo aquele em que a administração e execução das obras é efetivada mediante a contribuição em horas trabalhadas pelos próprios interessados, havendo contratação de mão de obra para determinadas tarefas, sendo a administração realizada pela associação e assessorada pela equipe técnica. Portanto, para que haja AUTOGESTÃO e MUTIRÃO é necessária a presença de todas as famílias nas comissões e na obra, organizadas de acordo com este regulamento. ${ }^{76}$

O Regulamento foi discutido em uma série de reuniões e aprovados em uma assembleia geral, Cada família recebeu um exemplar e o documento foi registrado em cartório e entregue à Caixa. Além de organizar o cotidiano da obra (ver Tabela 8), também dá a base formal para a aplicação de penalidades ou a exclusão de uma família mutirante que não cumpra com as responsabilidades acordadas coletivamente.

Tabela 8 - Lista de atividades mensais obrigatórias para os mutirantes

\begin{tabular}{l|l}
\hline Assembleia Geral & 1 domingo $(4 \mathrm{hs})$ \\
\hline Trabalho Social & 1 domingo $(4 \mathrm{hs})$ \\
\hline Obra & 2 dias $(16 \mathrm{hs})$ \\
\hline Vigília noturna & 1 noite $(10 \mathrm{hs})$ \\
\hline Trabalho em comissões & Média de $5 \mathrm{hs}$ \\
\hline Total no mês & $\mathbf{3 9}$ hs \\
\hline
\end{tabular}

Fonte: MST Leste 1, Regulamento de Obras, 2011

\footnotetext{
${ }^{76}$ Regulamento de Obras e Participação, 2011, p.1
} 
. As atividades são registradas pela equipe de Pontuação, que acompanha o desempenho de cada família, aplica as sanções previstas, se for o caso, e serviram para a escolha do apartamento na última etapa da obra.

Todas as famílias participam em pelo menos uma das 16 Comissões de trabalho. As comissões são responsáveis pelos mais diversos temas, que se relacionam com o andamento da obra, a organização interna dos mutirantes e com aspectos da vida comunitária dentro e fora do empreendimento. Na fase final de obra foram criadas mais três comissões com objetivo de preparar a pós-ocupação.

Tabela 9 - Lista das comissões de trabalho

\begin{tabular}{|c|c|c|}
\hline \multicolumn{2}{|c|}{ Comissão } & \multirow{2}{*}{$\begin{array}{l}\text { Atribuição } \\
\text { Realiza as movimentações financeiras e faz o planejamento } \\
\text { financeiro da obra. }\end{array}$} \\
\hline $\begin{array}{l}1 . \\
\text { empr }\end{array}$ & $\begin{array}{l}\text { Representantes } \\
\text { endimento }\end{array}$ & \\
\hline 2. & Prestação de contas & $\begin{array}{l}\text { Acompanhar a movimentação financeira de todos os } \\
\text { recursos da obra e apresenta seu relatório em assembleia. }\end{array}$ \\
\hline 3. & Conselho Fiscal & $\begin{array}{l}\text { Verifica o relatório de prestação de contas e os documentos } \\
\text { comprobatórios }\end{array}$ \\
\hline 4. & Obra & Organiza as atividades/tarefas dos mutirantes na obra. \\
\hline $\begin{array}{l}5 . \\
\text { obra }\end{array}$ & Acompanhamento & $\begin{array}{l}\text { Acompanha as visitas do agente financeiro em dias de } \\
\text { medição e apoiar o planejamento da obra. }\end{array}$ \\
\hline 6. & Compras & Cuida dos orçamentos da obra. \\
\hline 7. & Almoxarifado & $\begin{array}{l}\text { Organiza o recebimento e destinação dos materiais e } \\
\text { ferramentas durante a jornada de mutirão. }\end{array}$ \\
\hline 8. & Prevenção de acidente & $\begin{array}{l}\text { Assegura o cumprimento das regras de segurança pelos } \\
\text { mutirantes nas atividades de obra e o uso de equipamentos } \\
\text { de proteção coletiva e individual. }\end{array}$ \\
\hline 9. & Socioeducativo & $\begin{array}{l}\text { Desenvolve atividade com crianças e adolescentes durante } \\
\text { os dias de mutirão e atividades para integração destes ao } \\
\text { processo de mutirão. }\end{array}$ \\
\hline & Saúde & $\begin{array}{l}\text { Avalia as condições de saúde das famílias para execução } \\
\text { das tarefas de obra e apoia em caso de doença. }\end{array}$ \\
\hline & Cozinha & Prepara a alimentação dos mutirantes nos períodos de obra. \\
\hline & Pontuação & $\begin{array}{l}\text { Faz o apontamento das presenças das famílias nas } \\
\text { atividades obrigatórias e facultativas da obra e apresenta } \\
\text { relatório periódico; }\end{array}$ \\
\hline & Comunicação & Divulga as informações do andamento do empreendimento \\
\hline
\end{tabular}




\begin{tabular}{|c|c|}
\hline & e outras de interesse do grupo. \\
\hline Limpeza & Zela pela limpeza dos locais de uso comum do canteiro. \\
\hline Segurança & $\begin{array}{l}\text { Organiza as atividades que visam a segurança do canteiro, } \\
\text { como vigílias e prevenção de furtos. }\end{array}$ \\
\hline Idosos & $\begin{array}{l}\text { Apoia os mutirantes idosos na sua participação no mutirão e } \\
\text { acesso a direitos básicos. }\end{array}$ \\
\hline \multicolumn{2}{|c|}{ Comissões criadas para a fase final de obra } \\
\hline $\begin{array}{l}\text { 17. Articulação com } 0 \\
\text { entorno }\end{array}$ & $\begin{array}{l}\text { Organiza o relacionamento com entidades, condomínios e } \\
\text { outras forças sociais do bairro }\end{array}$ \\
\hline $\begin{array}{l}\text { 18. Organização } \\
\text { condomínio }\end{array}$ & Prepara o grupo para a constituição do condomínio \\
\hline $\begin{array}{l}\text { 19. Associação } \\
\text { Moradores }\end{array}$ & $\begin{array}{l}\text { Organiza os moradores para necessidade e lutas } \\
\text { relacionadas a outros direitos }\end{array}$ \\
\hline
\end{tabular}

Fonte: MST Leste 1, organizada pelo autor

Figuras 24 e 25 - Reunião de comissão de trabalho
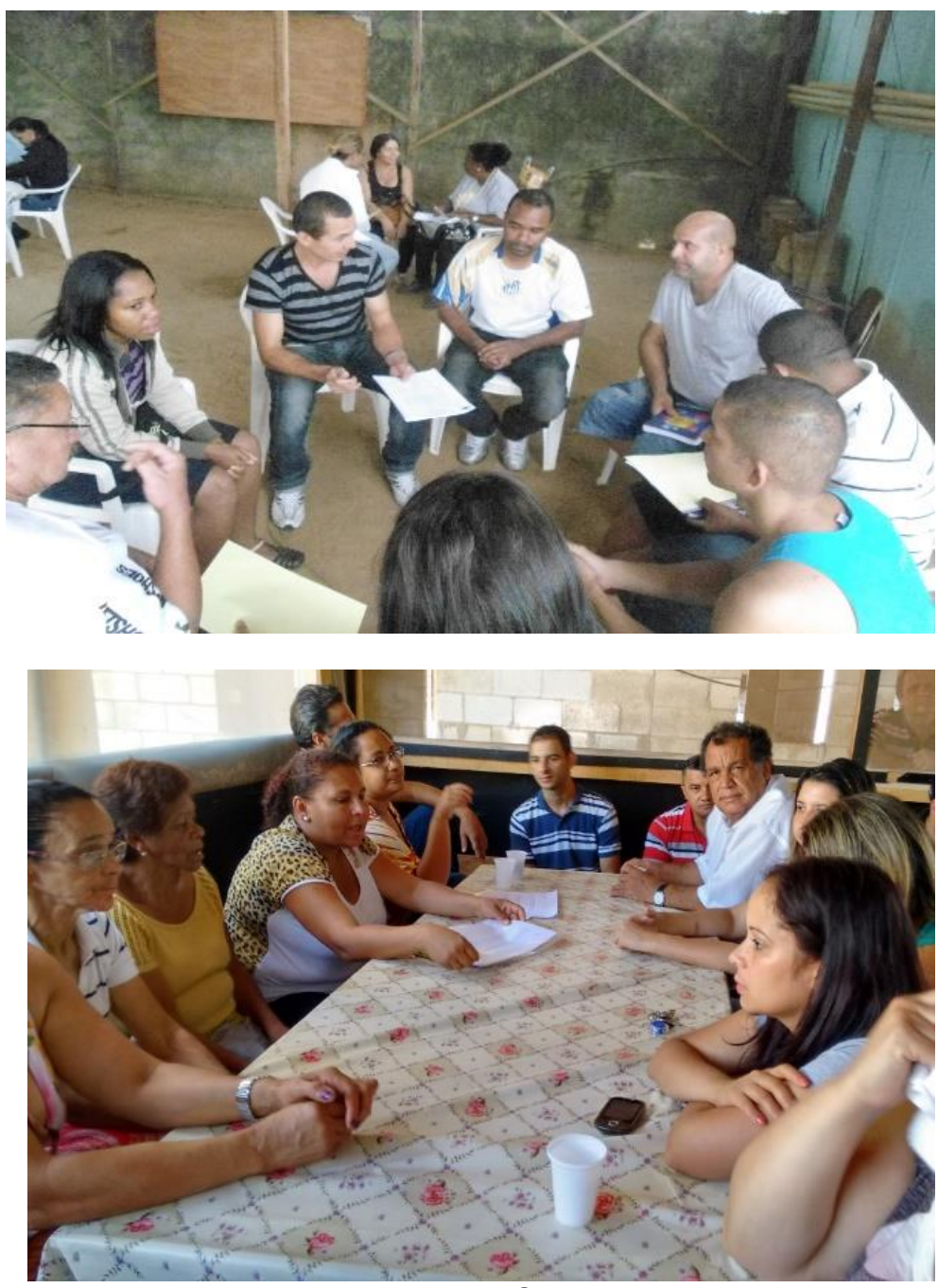

Fonte: Acervo do MST Leste 1 
Além disso, todos os mutirantes participavam, uma vez ao mês, de uma atividade desenvolvida pela equipe de trabalho social.

\subsection{Trabalho Social}

A opção do movimento foi desenvolver todo o trabalho social com a contratação de profissionais da área diretamente pelo movimento, que trabalhou em articulação com a coordenação de obra, a direção do movimento e a assessoria técnica.

As atividades de trabalho social focaram na preparação do grupo e das comissões para o processo autogestionário na etapa pré-obra. Durante a fase de obras, o trabalho social apoiou a coordenação e o funcionamento das comissões, principalmente na integração de seus temas e também na discussão de temas cidadãos, como direitos e políticas públicas setoriais, temas da conjuntura e ações de luta do movimento.

Figura 26 - Feira de habilidades dos mutirantes

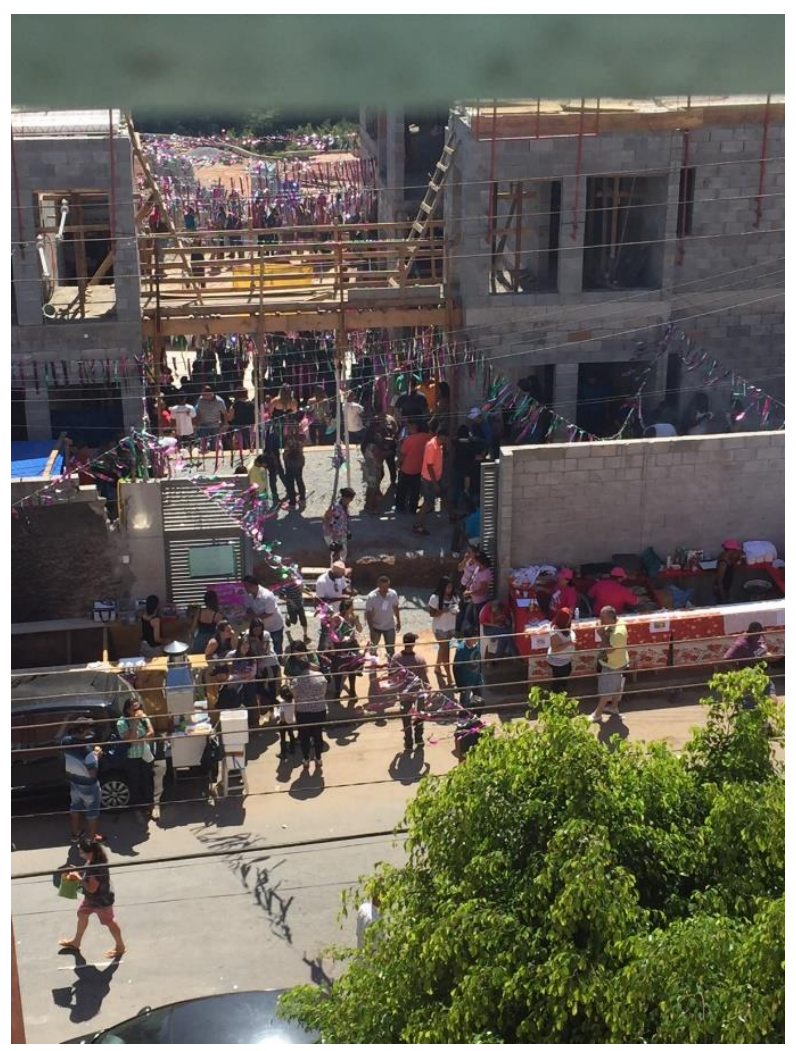

Fonte: Acervo do MST Leste 1 
Os normativos do programa exigiam a atuação do Trabalho Social nos seguintes Eixos: a) Organização Comunitária, b) Educação Ambiental, c) Educação Patrimonial, d) Planejamento e Gestão do Orçamento Familiar e e) Geração de Trabalho e Renda ${ }^{77}$, que foram desenvolvidos nas atividades mensais, com a proposta de geração de autonomia do grupo.

Já no período de finalização da obra, o trabalho social concentrou-se na organização da convivência no período de pós-ocupação, na formação do condomínio e na organização de uma associação de moradores para o enfrentamento das questões locais do bairro e da região.

Como explicado anteriormente, este escopo é muito maior do que aquele exigido pelo programa, mas avaliado pelo movimento como indispensável para o bom andamento do processo autogestionário e para a organização do grupo. Além disso, as liberações financeiras acompanhavam o avanço de obras, fazendo com que, em diversos momentos em que a obra andou mais lentamente ou foi paralisada, não houvesse recursos para a manutenção dos profissionais. O movimento teve que buscar outras fontes e, muitas vezes reduzir o quadro de profissionais e a remuneração destes, para enfrentar essa situação.

\subsection{Organização do trabalho mutirante}

Para organizar o trabalho mutirante, as 198 famílias de cada empreendimento estão divididas em 3 grupos, esses grupos estão caracterizados pelas cores rosa, azul e amarelo. Em dias de obra, os mutirantes de cada empreendimento estão caracterizados pela cor do capacete, sendo o Florestan Fernandes com capacete azul, e José Maria Amaral com capacete laranja, no entanto, não havia divisão física ou de tarefas entre os dois mutirões: todas as famílias trabalhavam indiscriminadamente nos dois canteiros. Todas as famílias deveriam cumprir um total idêntico de horas de trabalho. A família era responsável por, no mínimo, $60 \%$ das horas de trabalho mutirante e o restante, poderia, eventualmente, ser realizada por algum substituto. A regra foi definida para garantir que nenhuma família delegasse ou contratasse terceiros para o mutirão.

\footnotetext{
77 Conforme instrução normativa nำ 45, de 8 de novembro de 2012
} 
Logo de início, foi colocada a questão sobre quais trabalhos seriam desenvolvidos por mutirantes e quais seriam por mão de obra especializada contratada. Um primeiro elemento colocado foi o risco que envolve o trabalho em altura e o pequeno número de mutirantes que já possuíam experiência em construção civil com esse porte. Dessa forma, tomou-se a decisão de que os mutirantes somente trabalhariam "no chão" até que os edifícios estivessem com condições de segurança suficiente para que os mutirantes "subissem". Como os empreendimentos foram construídos no sistema de alvenaria estrutural, todo o trabalho para a construção das paredes e lajes foram feitos por mão de obra especializada contratada.

Dessa forma, os trabalhos executados pelos mutirantes nessa primeira fase da obra foram basicamente de apoio ao trabalho dos contratados: transporte de material para o local dos blocos, limpeza do canteiro com reciclagem dos materiais descartados, aterros e compactação das fundações, manutenção do canteiro, além da recuperação da APP. Para evitar uma alienação das famílias em relação ao que estava sendo construído, periodicamente, organizavam-se visitas de grupos de mutirantes aos blocos ainda em obras.

Figura 27 - Transporte de material em mutirão - "formiguinha"

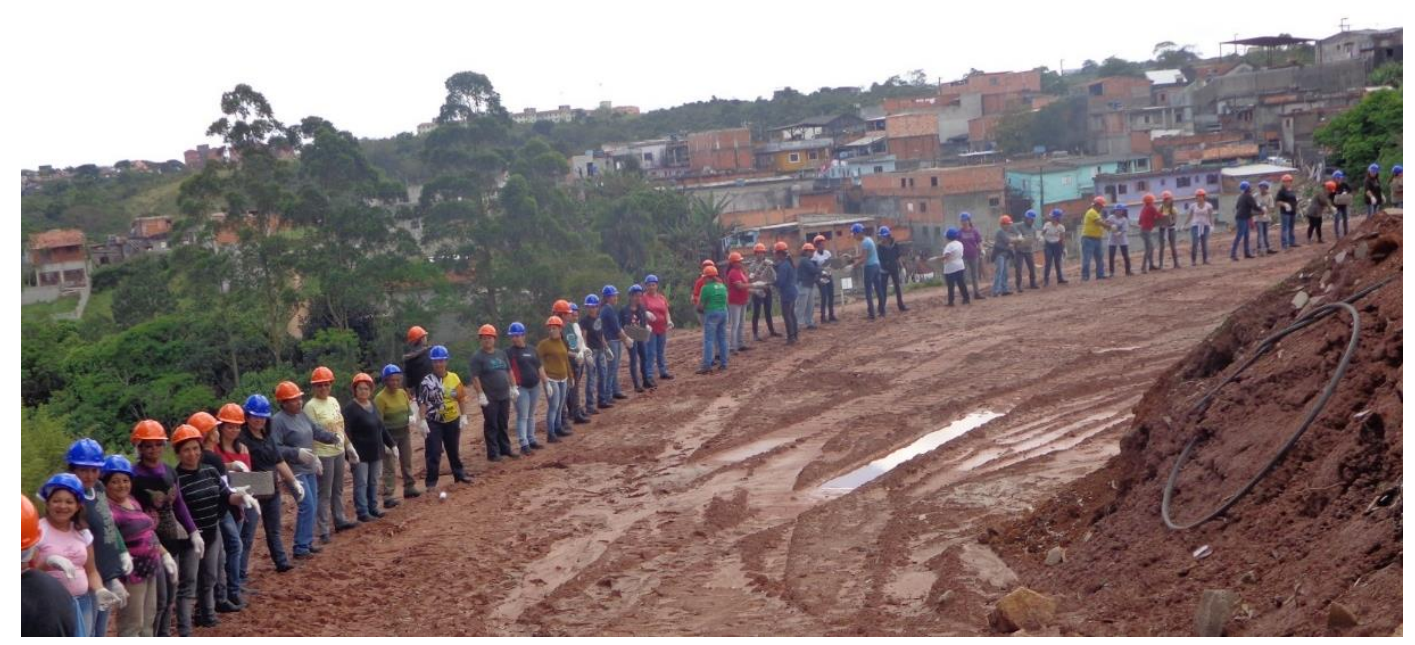

Fonte: Acervo do MST Leste 1 
Figura 28 - Organização de dia de obra

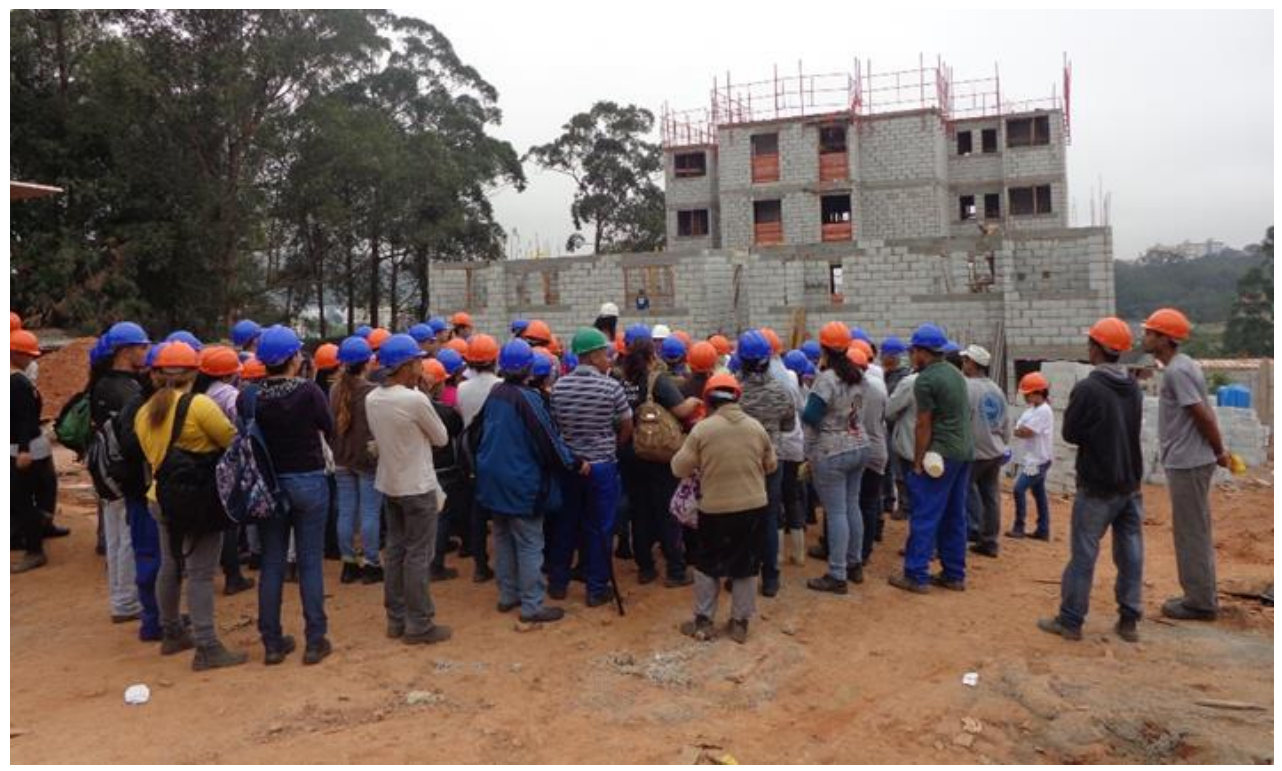

Fonte: Acervo do MST Leste 1

Figura 29 - Resultado do trabalho em uma jornada de Mutirão

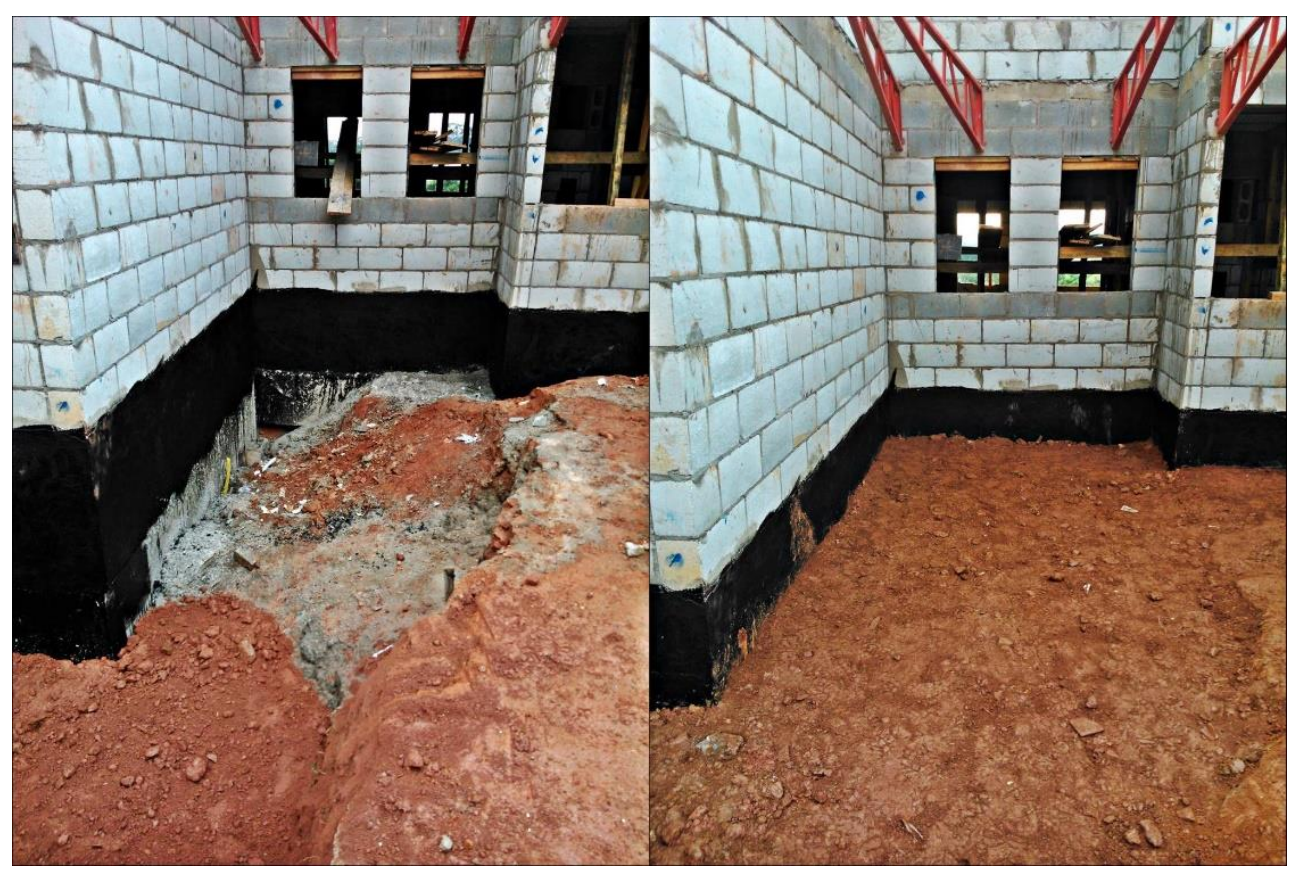

Fonte: Acervo do MST Leste 1

Assim, somente quando já os edifícios estavam erguidos e com as áreas de risco devidamente protegidas é que foram iniciados trabalhos dentro da área comum dos blocos e dos apartamentos, tais como limpeza das unidades, pintura das áreas comuns e da escada de emergência, rejunte dos pisos e revestimentos internos, 
preparo das portas de madeira. Até esse momento, as famílias não haviam feito a escolha de sua unidade e, portanto, trabalhavam indiscriminadamente em todos os blocos. Esse é um dos princípios defendidos pelo movimento, desde a produção de casas térreas e que seguiu também na produção verticalizada.

Já na última etapa da obra, como processo de escolha tendo sido concluído, as famílias puderam dedicar parte de seu tempo de trabalho mutirante para o acabamento de sua unidade, além de seguir o trabalho coletivo nas áreas comuns.

Uma questão nova enfrentada pelo movimento foi a de que havia parte significativa dos mutirantes que não exercia atividades braçais em sua vida cotidiana. O movimento avaliou que esse fato deveu-se tanto ao aumento de escolaridade nas periferias quanto ao recuo da atividade industrial na Região Metropolitana de São Paulo. No momento da contratação da fase de obras do empreendimento, em 2012, um levantamento feito pela equipe de trabalho social verificou que a maioria dos integrantes do grupo era de trabalhadores do setor de serviços e poucos atuavam no setor industrial ou de construção civil. Nesse sentido, poucos conheciam a dinâmica de uma obra.

\subsection{Organização da gestão - coordenação e assembleia}

Para a coordenação de todo processo produção dos empreendimentos foi constituída uma instância denominada coordenação. A coordenação é composta por representantes das comissões dos dois empreendimentos, todos os membros da CAO e CRE dos dois empreendimentos, representante da coordenação executiva do MST Leste 1 e acompanhada pela assessoria técnica e pela equipe de trabalho social. A coordenação se reunia semanalmente, porém nem sempre com a presença de todos os seus membros. 


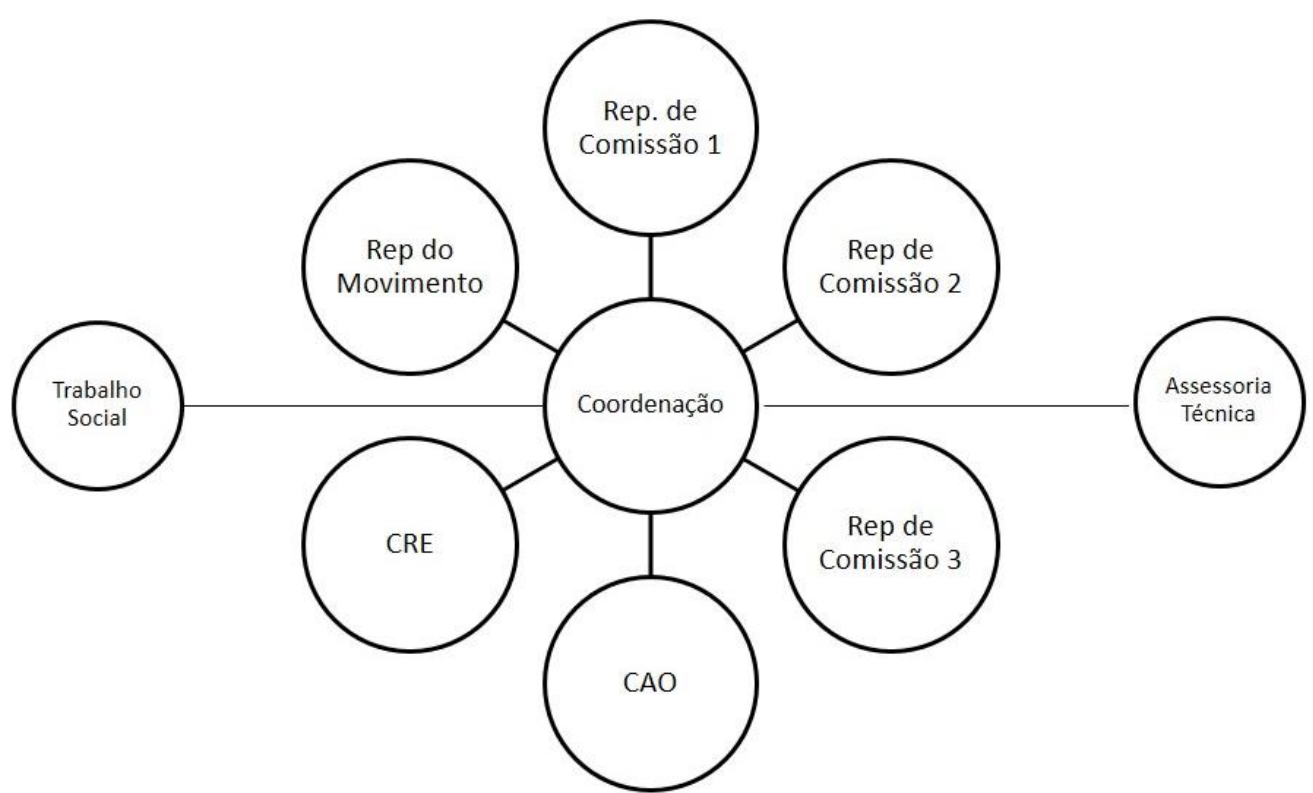

Fonte: MST Leste 1, Comissões de trabalho, administração de Obra e da Entidade, Trabalho em Mutirão, powerpoint de 2015

As decisões sobre todos os processos da obra (compras, contratações, etapas a serem desenvolvidas) são tomadas pela coordenação em sua reunião semanal, que também determinam as atividades mutirantes e para a mão de obra contratada. Na coordenação também se discutia as atividades de cada comissão e de como essas apoiavam o conjunto da obra. Também é um espaço de disseminação de informação, pois cada representante tem a reponsabilidade de transmitir as informações discutidas a seu grupo. No entanto, muitos dos representantes apresentaram dificuldades em desempenhar esse papel, o que exigia que determinados temas de maior complexidade fossem discutidos também nas atividades de trabalho social.

Ao longo do tempo, foi-se estabelecendo uma rotina que delegava à equipe administrativa da obra, algumas dessas funções. A equipe administrativa era composta por uma representante do movimento, que já possuía experiência em autogestão $^{78}$, e uma mutirante de cada um dos empreendimentos. Essa equipe foi contratada formalmente para trabalhar no canteiro durante a semana e implementar as decisões tomadas pela coordenação e assembleia. Cabia à equipe administrativa

\footnotetext{
${ }^{78}$ Coordenadora Executiva do MST Leste 1 e integrante do Mutirão Paulo Freire.
} 
coordenar as atividades na obra que acontecem de segunda a sexta - feira, por mão de obra contratada.

Os temas de maior relevância, bem como os desafios e dificuldades enfrentados durante a execução da obra e do contrato, no entanto, eram sempre debatidos em assembleia. As assembleias tinham periodicidade mensal e eram realizadas separadamente entre os dois empreendimentos. Apenas em algumas situações, em que era necessário em que se chegasse a uma deliberação comum, foram realizadas assembleias conjuntas.

$\mathrm{Na}$ Assembleia, além da organização para as demais lutas gerais e do movimento, acontecia a discussão do andamento da obra com todas as famílias e a prestação de contas dos recursos recebidos e gastos. Também a assembleia e decidia qual melhor solução para os problemas encontrados ao longo da implementação da obra, bem como do andamento junto aos diversos órgãos públicos que se relacionam como empreendimento.

Assim, a necessidade de pressão ou mobilização para enfrentamento de questões mais abrangentes, como mudanças de conjuntura política e do programa, ou específicas dos empreendimentos, como a aprovação de uma licença, eram discutidas e aprovadas pelo conjunto das famílias. A mobilização do grupo para essas atividades, no entanto, foi bastante irregular, com alguns momentos de grande participação e outros com clara omissão, delegando à coordenação essa responsabilidade.

Figuras 31 e 32 - Assembleia durante a fase de obras

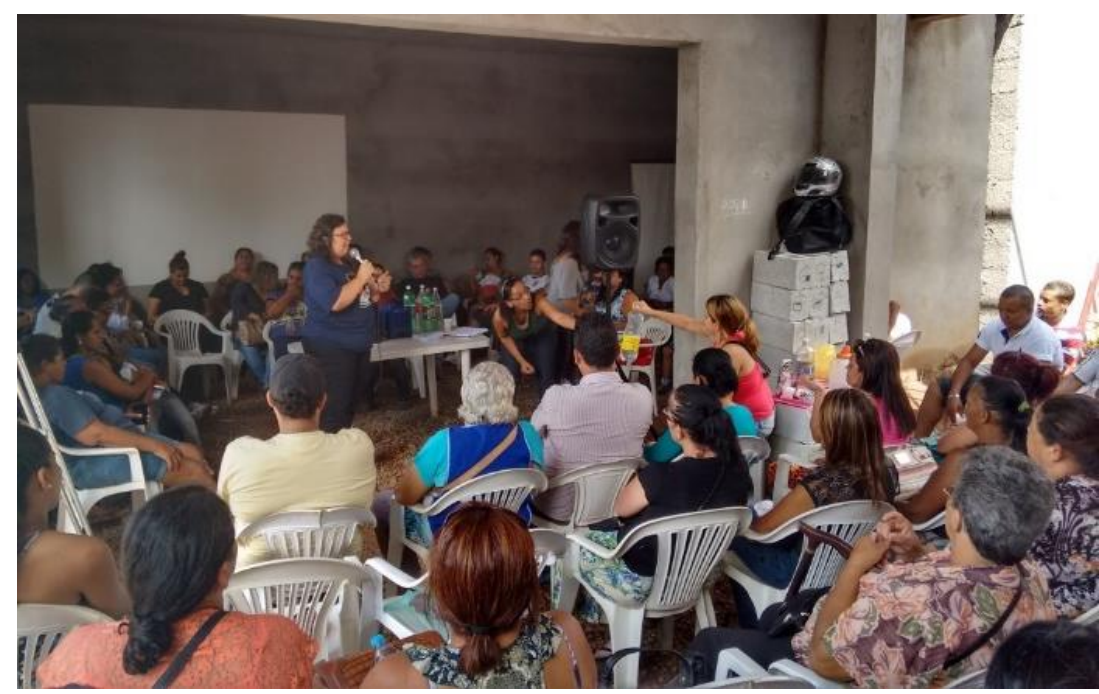




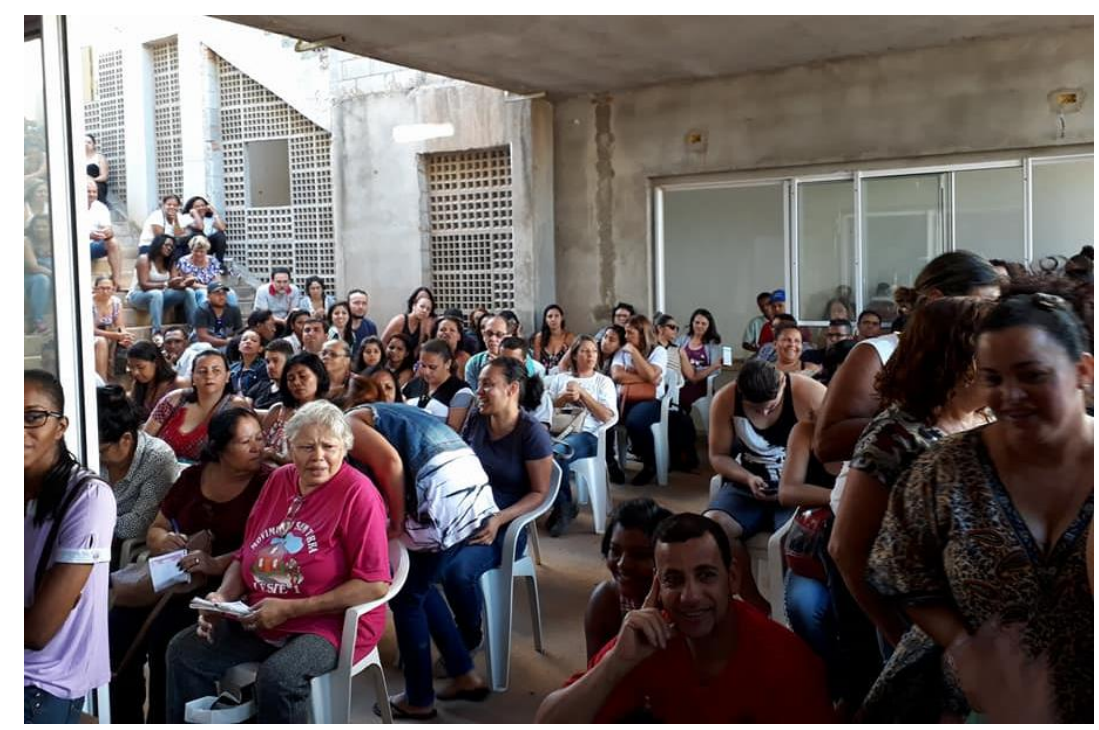

Fonte: Acervo do MST Leste 1

Também era na assembleia que os conflitos internos mais afloravam, muitas vezes relacionados com as formas de solucionar os problemas encontrados, como na forma de relacionar-se com as ausências ou descumprimentos do regulamento. Nessa questão, duas posições se destacavam: daqueles que defendiam a aplicação das regras sem espaço para mediação, excluindo os que não se enquadravam; e daqueles que tudo relevavam, e que empurravam esse tipo de questão sempre para uma próxima ocasião. Via de regra, a Assembleia sempre acolhia as justificativas apresentadas, quando acompanhadas de um compromisso de mudança de atitude do mutirante. Mas era implacável, aprovando a exclusão daqueles que não se justificavam ou que, reiteradas vezes, não mudavam seu comportamento perante $o$ grupo.

Também nas assembleias acontecia a discussão do andamento da obra. Como as informações de cronograma e da planilha de acompanhamento de serviços da Caixa eram muito complexas e detalhadas, a assessoria técnica desenvolveu algumas formas gráficas de representação, com um boletim (Figura 33) a ser entregue mensalmente às famílias, onde, além do percentual executado, os blocos estavam representados, com a situação no momento. Essa forma de apresentação somada ao conhecimento do canteiro facilitou as discussões tomadas de decisão sobre o andamento da obra e, nos momentos de interrupções, deu mais clareza ao que precisava ser feito. 
Figura 33 - Exemplo de boletim de andamento de obra

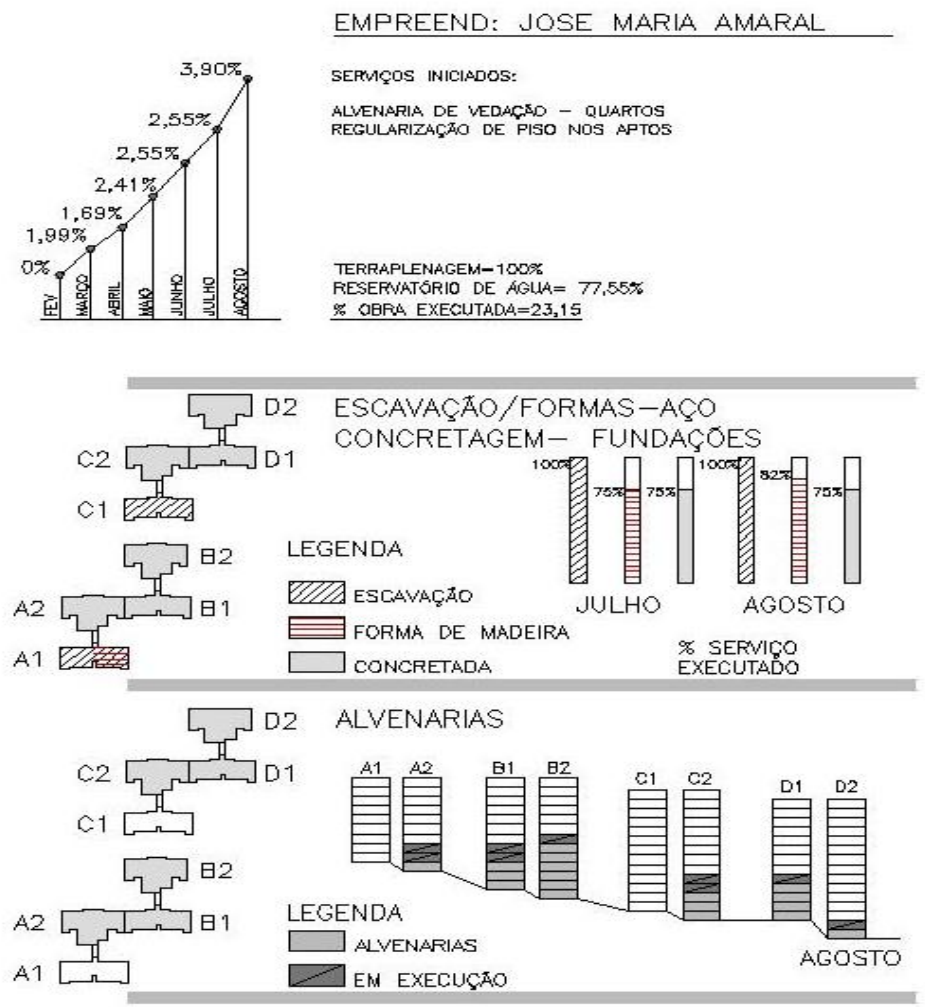

Fonte: Ambiente Arquitetura

Além disso, em cada Assembleia eram discutidos os serviços serem executados no próximo período, tanto pela mão de obra contratada, como pelos mutirantes, levando-se em consideração os recursos disponíveis e as porcentagens a serem atingidas para a seguinte medição. Também eram debatidos os itens que tiveram superávit ou déficit, comparados à planilha orçamentária aprovada pela Caixa.

A assembleia também teve como pauta a definição de alguns itens relevantes, onde era possível ter soluções diversas. O fornecedor dos elevadores foi um dos pontos mais aprofundados, pois tratava-se de um ponto crítico da obra, tanto por causa de seu alto custo, tanto pela preocupação com a manutenção posterior. A Comissão de Acompanhamento de Obras e a Comissão de Cotação, acompanhadas pela assessoria técnica, visitaram diversas empresas e analisaram as propostas de cada uma delas, tanto de fornecimento quanto de manutenção. Quando o tema foi levado à assembleia, foi acompanhada de uma avaliação da coordenação, para dar os elementos para a tomada de decisão. A empresa melhor avaliada pelas comissões foi a escolhida, demonstrando o peso dessa avaliação. 
Processos semelhantes ocorreram com o fornecimento de janelas, portas, pisos e revestimentos internos e externos.

Figura 34 - Assembleia para escolha dos acabamentos externos

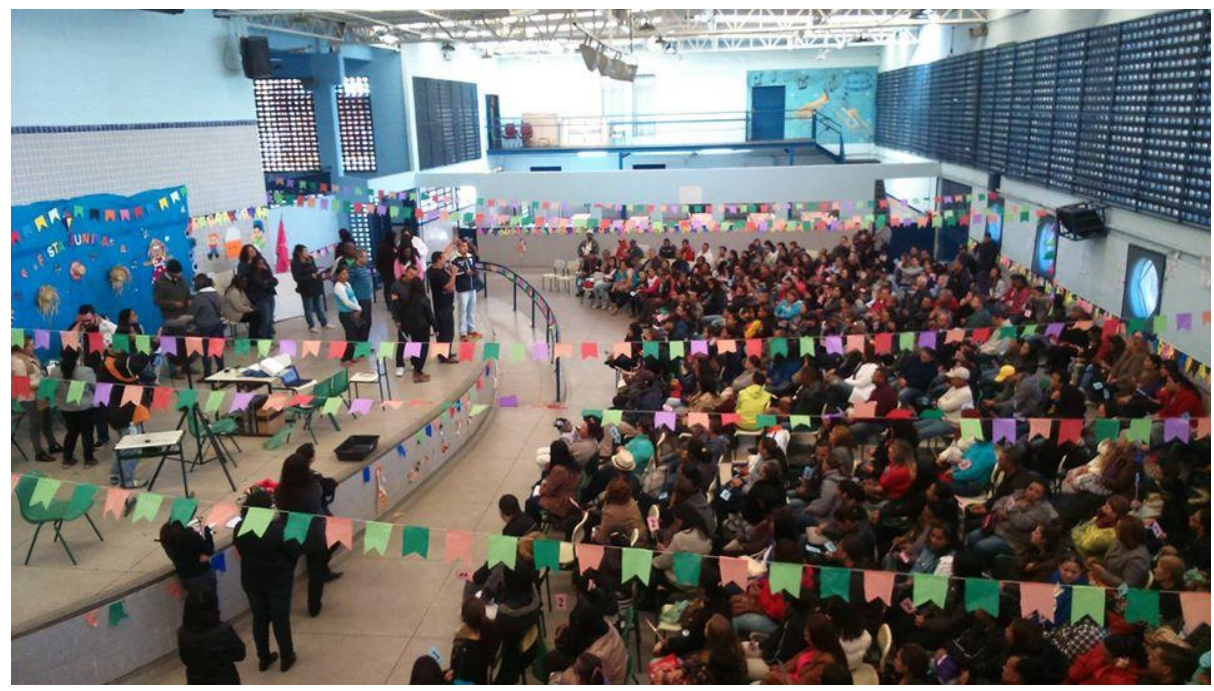

Fonte: Acervo do MST Leste 1

Figura 35 - Votação para escolha dos acabamentos externos

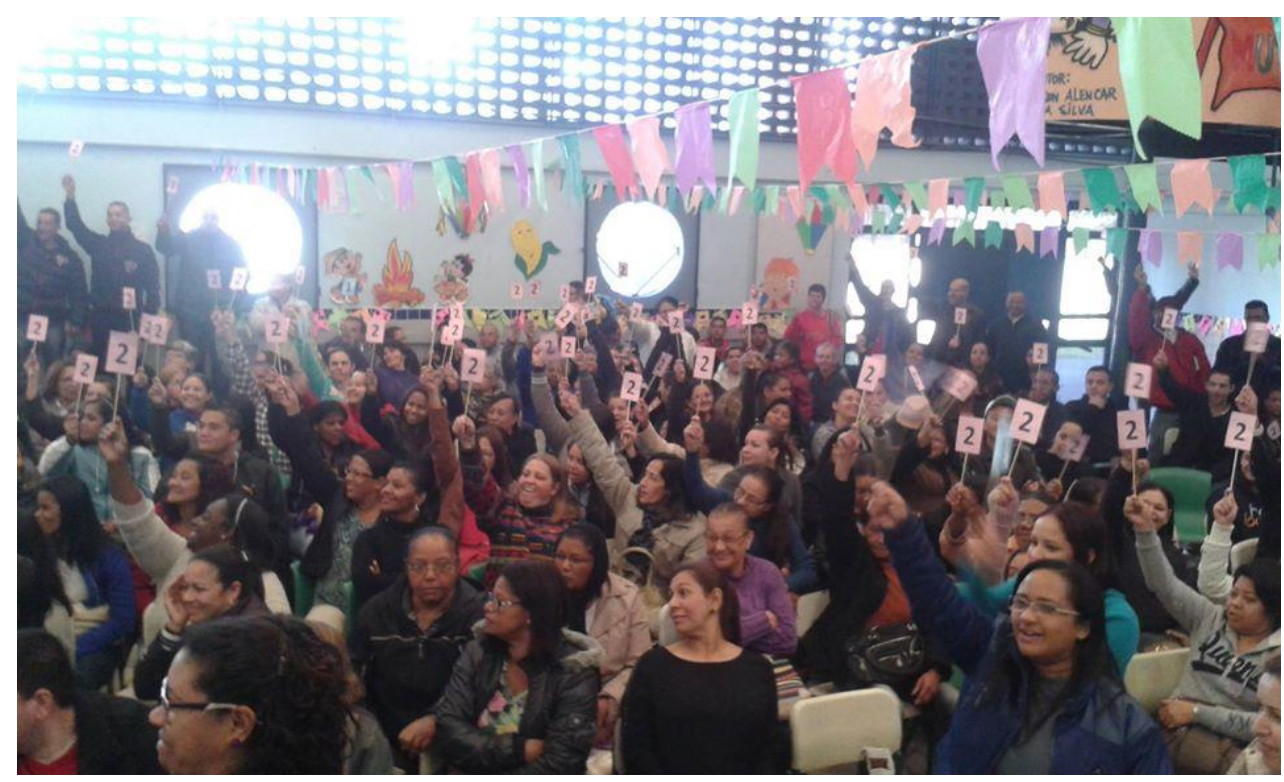

Fonte: Acervo do MST Leste 1

\subsection{Gestão coletiva das Finanças}

Nos empreendimentos Florestan Fernandes e José Maria Amaral, a coordenação acordou de que a CRE deveria transferir o valor integral das liberações 
dos recursos públicos (FDS, aporte estadual e municipal) que vinham na conta das pessoas físicas integrantes da CRE para uma conta bancária específica do empreendimento em nome da associação e era movimentada pela equipe administrativa. A CRE acompanhava a execução financeira dos empreendimentos em conjunto com a coordenação e a Comissão de Prestação de Contas.

Foi estabelecido um sistema para a realização da prestação de contas tanto dos recursos recebidos do poder público, quanto para a contrapartida e eventuais rateios de custos específicos. Todos os pagamentos eram feitos pela equipe administrativa, acordados tanto com a coordenação quanto com a assessoria técnica. Apesar do programa não possuir exigência de prestação de contas formal ao agente financeiro, o grupo estabeleceu suas próprias regras de movimentação financeira, como que a movimentação se desse apenas por meio de cheque ou transferência eletrônica diretamente ao fornecedor, sem a movimentação de qualquer valor em espécie no canteiro.

A prestação de contas era feita mensalmente pela comissão afim, a partir da documentação disponibilizada pela equipe administrativa, com extrato bancário, cópia de cheque ou transferência eletrônica, cópia dos comprovantes (nota fiscal), boletos e quitação de pagamento, quando fosse o caso e elaborar uma pasta com toda a documentação e uma planilha com as entradas e saídas do mês. Após esse procedimento, o Conselho Fiscal deveria verificar a consistência das informações. $\mathrm{Na}$ assembleia, a comissão de finanças apresentava a planilha com a leitura de todos os itens e entregava uma cópia física para todos os mutirantes. Eventuais questionamentos tanto sobre os valores, quanto da pertinência do gasto na etapa de obra eram esclarecidos pela equipe administrativa e pela assessoria técnica. Nos momentos de muitas frentes de obra simultâneas, tal apresentação se tornava muito extensa e não dava condições para uma melhor avaliação das famílias. Para uma melhor compreensão, além da planilha, passou-se adotar um resumo, agrupando os gastos em rubricas. Também, em alguns momentos, isolava-se um item específico, como fundações ou revestimento externo, por exemplo, somando-se os gastos em diversos meses para demonstrar o peso desse item ou se ele teria tido déficit ou superávit.

Esses expedientes foram adotados no sentido de dar maior transparência à utilização dos recursos financeiros e também para apoiar o planejamento das etapas 
subsequentes. Também foram bastante úteis na solicitação do aporte à prefeitura municipal e nas solicitações de prorrogação e reprogramação da obra.

No entanto, ainda se verifica a grande dificuldade de que esses processos sejam apropriados pela maioria das famílias. Muitas relações são estabelecidas baseadas nas relações de confiança do que nos procedimentos de prestação de contas. O que não impede que parte das famílias levantem dúvidas sobre a lisura do processo e, especialmente nos momentos de maior dificuldade da obra, questionem a existência de irregularidades ou má destinação dos recursos. Em assembleia no $2^{\circ}$. Semestre de 2019, após diversos questionamentos, a coordenação sugeriu a formação de uma comissão interna de auditoria, composta por mutirantes. Apesar de ter sido aprovada e realizado algumas reuniões, a auditoria não tem sido realizada pelos seus membros.

\subsection{Compras e contratações}

Desde a primeira liberação financeira de obra, foram definidos alguns procedimentos para a contratação de serviços e aquisição de materiais. Para isso, era fundamental o funcionamento da comissão de compras, que na realidade, não efetuava as compras mas tinha como função fazer a cotação dos materiais e serviços definidos pela AT e discutidos pela coordenação para a etapa de obras a ser executada com a parcela liberada.

A comissão de compras tinha como tarefa conseguir ao menos três orçamentos de cada um dos itens definidos, com as especificações técnicas apresentadas pela AT. Se, em empreendimentos anteriores, essas cotações eram feitas por telefone e às vezes pessoalmente, no Florestan Fernandes e José Maria Amaral, as cotações eram, em sua maioria, feitas por e-mail e por páginas de internet. Para facilitar o trabalho, foi criada uma pasta em ambiente virtual, onde a AT colocava a especificação do material ou serviço a ser cotado e os membros da comissão, ao longo da semana, inseriam as cotações. Em reuniões no final de semana, a comissão e a AT avaliavam os materiais recebidos, descartavam aqueles que não cumpriam as especificações e levavam à coordenação aqueles que julgavam adequados para a definição final. 
Figura 36 - Ciclo de cotação e compra de materiais ou contratação de serviços

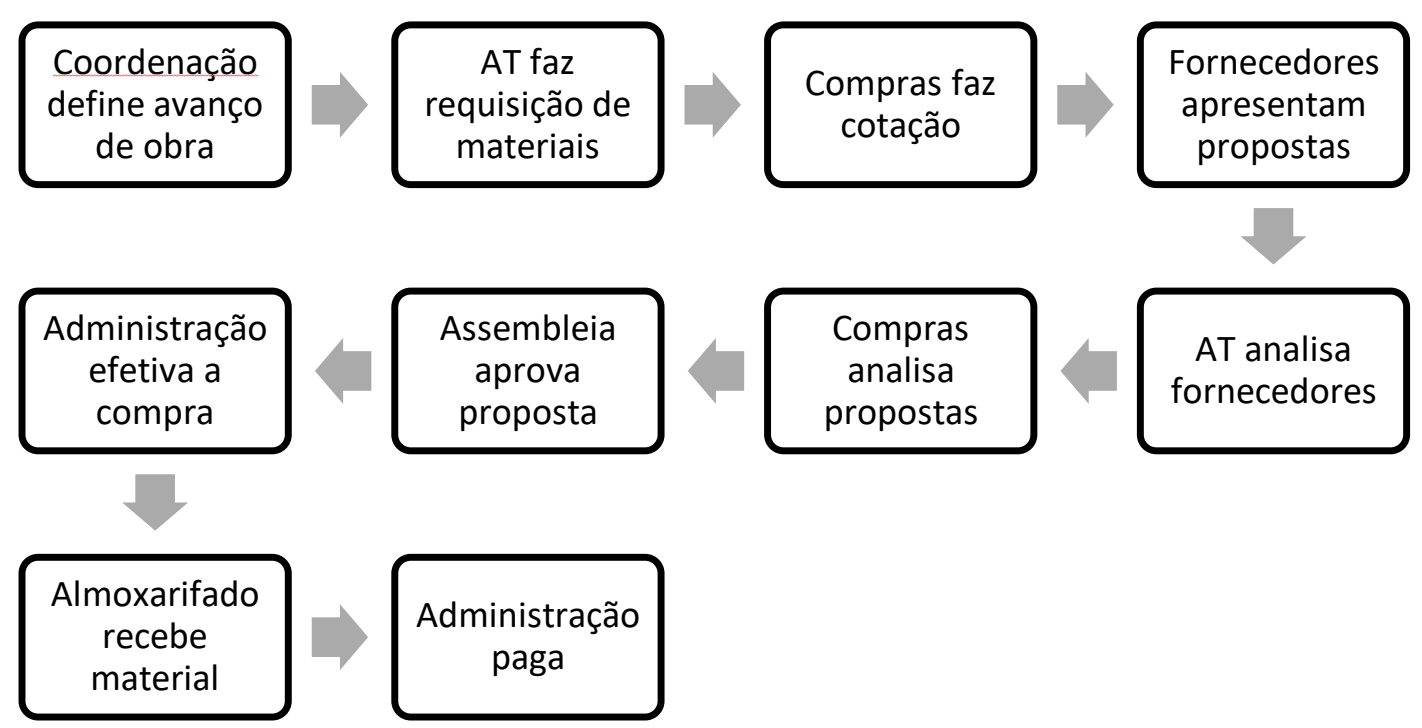

Fonte: Elaborada pelo autor com base em dados coletados em campo

Para os grandes itens, esse processo poderia levar muito mais tempo e envolver outros processos de checagem e negociação com os fornecedores e o processo de definição levava mais tempo, podendo chegar até à definição pela assembleia, como exposto acima. Em alguns momentos, a comissão não conseguia fazer as cotações a tempo da necessidade do avanço de obra, fazendo com que a administração assumisse a tarefa para que não houvesse atraso ou interrupção na obra. Esse fato foi motivo de alguns conflitos entre a coordenação e a comissão, que alegava pouco tempo disponível para execução da tarefa ou que a administração estaria extrapolando suas atribuições. Ao longo da obra, essa questão foi sendo ajustada. Também foi necessário a capacitação de alguns membros que não estavam habilitados para o uso da ferramenta virtual e, em alguns casos, que a administração fornecesse e recebesse o material impresso, para possibilitar a participação de alguns membros.

Um aspecto bastante importante do processo foi a definição da forma de contratação dos trabalhadores da obra. $O$ movimento, baseado em suas experiências anteriores e também na forma executada por outros grupos da UMM, decidiu que apenas faria a contratação direta, com registro em carteira, dos funcionários da administração da obra, mestres e encarregados de obra, almoxarife e técnico em segurança do trabalho. Os demais trabalhadores foram contratados por meio de empresas de mão de obra. Também definiu que não contrataria apenas 
uma única empresa para que a obra não ficasse totalmente dependente dessa. Assim foram contratadas quatro empresas que, a princípio ficaram responsáveis por uma torre cada uma. De acordo com o andamento da obra, a empresa receberia mais frentes de obra ou, ao contrário, findaria o seu contrato com o movimento.

Coube às empresas contratadas a formalização de todos os seus trabalhadores em canteiro, bem como o cumprimento da legislação e a convenção trabalhistas e o pagamento dos encargos devidos. O movimento, no entanto, tinha 0 dever de acompanhamento.

\subsection{Vigília e caseiros}

Um dos pontos de desafio e gerador de conflitos desde o início do processo foi a forma de se garantir a segurança do empreendimento, em suas diferentes fases. As preocupações se deviam tanto à possibilidade de ocupação do terreno inicialmente e da obra e das unidades, já na fase final e também de roubos e furtos dos materiais, especialmente aqueles com maior valor unitário.

Durante a fase de projeto, foram escolhidas duas famílias para morarem no terreno como caseiros. Para isso, com a contrapartida das famílias, foram construídas em mutirão duas casas de madeira. Essa forma de segurança seguiu até a primeira fase de obra.

No entanto, com o início da obra, começaram acontecer alguns furtos de materiais de pequeno valor, como ferro, placas de compensado de madeira, cimento, entre outros. A partir daí, for decidido em assembleia a adoção de um sistema de vigílias, onde cada grupo de famílias deveria passar ao menos uma noite por mês no terreno. No entanto, ocorreu um assalto a mão armada, o que levou a parte dos mutirantes questionar a eficácia e também os riscos que envolviam as vigílias. $\mathrm{Na}$ assembleia seguintes, várias propostas foram apresentadas, desde a contratação de policiais fora de horário de serviço até ao pagamento por proteção ao grupo que comandava o tráfico na região. A proposta que venceu a votação foi a de reforçar a vigília e exigir a presença de todos com mais intensidade. As vigílias foram realizadas de forma permanente, inclusive nos dias de feriado, quando os riscos de ocupação são considerados maiores. Foram realizadas ceias de natal e ano novo no 
terreno, dentre outras atividades, para amenizar as dificuldades na sua realização. As vigílias, no entanto, seguiram sendo fonte de diversos conflitos internos.

Importante também ressaltar a relação com o entorno. O terreno dos empreendimentos está localizado ao lado de um empreendimento da CDHU, da década de 1990. O seu projeto faz com que a rua de acesso tanto ao conjunto quanto aos empreendimentos Florestan Fernandes e Jose Maria Amaral se localizem em uma rua sem saída, acessível somente para pedestres, por meio de uma escada e uma ponte sobre o Córrego do Rodeio. Esse isolamento faz com que o local tenha pontos de atuação do tráfico de drogas local, bem como pouca presença de policiamento. Não houve, no entanto, nenhuma interferência desse grupo na implementação do empreendimento. Uma ação do trabalho social reuniu, por algumas vezes, os síndicos dos prédios do conjunto da CDHU, para discutir problemas comuns no bairro.

A partir do final de 2017, quando os apartamentos já estavam mais acabados, houve uma avaliação tanto da eficácia da vigília frente a uma eventual ocupação, quanto ao desgaste das famílias. Decidiu-se em ampliar o número de caseiros, utilizando os andares mais baixos de todos os prédios, de modo já garantir uma presença efetiva em todo o tempo. Foram estabelecidos critérios e condutas necessárias para a definição desses caseiros, entendendo que o empreendimento ainda se encontrava em obras e deveria haver um maior cuidado para a prevenção de acidentes no canteiro. Foram definidos, em resumo, os seguintes critérios:
a) Ser titular de vaga no empreendimento;
b) Possuir família constituída com, no mínimo, dois integrantes adultos;
c) Comprometer-se com o conteúdo do contrato de comodato elaborado pela associação e discutido coletivamente;
d) Utilizar todos os equipamentos de segurança de obra e respeitar integralmente os demais regulamentos da entidade. ${ }^{79}$

No entanto, em agosto de 2019, a Caixa notificou o MST Leste 1 com a alegação de havia recebido uma denúncia de que havia apartamentos ocupados na obra, sem que houvesse sido finalizada a obra e, portanto sem a expedição do

\footnotetext{
${ }^{79}$ Ata da assembleia geral, 2018
} 
"habite-se" e que caso o movimento não desocupasse imediatamente os apartamentos, a entidade seria penalizada.

O movimento argumentou sobre a necessidade de ter adotado tal medida e acrescentando de que no estado de São Paulo, havia inúmeros exemplos de empreendimentos nos quais a ocupação irregular realizada por terceiros, causava grave prejuízo à administração pública e ao direito daqueles que esperam por atendimento habitacional.

Argumentou também que sendo a obra executada parcialmente em regime de mutirão, significa que os associados participam concretamente da execução dos serviços em canteiro, manuseando ferramentas, aportando mão de obra e executando atividades próprias da área da construção civil. Ou seja, a presença dos associados no canteiro, não constituía novidade ou fosse motivo de qualquer controvérsia razoável. Não seria possível executar a obra em mutirão não fosse a presença ativa das famílias no canteiro.

Acrescentou também que tal situação não era desconhecida pela Caixa, já que o movimento já a havia informado em reuniões e de que o técnico responsável pelas vistorias mensais também já havia constatado a presença dos caseiros em seus apartamentos.

Para propor uma solução para o caso, o MST Leste 1 argumentou:

"Como se buscou demonstrar, a existência de associados exercendo a posse direta dos imóveis é uma medida refletida, aprovada democraticamente pela coordenação do empreendimento e cercada dos cuidados necessários ao controle da situação excepcional a que o conjunto está submetido.

Entretanto, a proposta de solução que apresentamos refuta as soluções tradicionais que se materializam na litigiosidade como forma de superação dos conflitos.

Nesse sentido, solicitamos que seja analisada a hipótese de celebração de um TAC (termo administrativo de ajustamento de conduta), como forma de solução mediada que não implique em redução das medidas de segurança e estabeleça os mecanismos necessários à formalização da estratégia de conclusão da obra" ${ }^{\text {80 }}$.

\footnotetext{
${ }^{80}$ MST Leste 1 - Ofício enviado ao Agente financeiro, em setembro de 2019.
} 
O TAC é uma espécie de acordo entre a administração e os administrados (agentes regulados). De maneira geral, pode-se afirmar que o TAC tem como objetivo principal a adequação das condutas irregulares praticadas pelos agentes (descumprimento de obrigações previstas na legislação, regulamentação e instrumentos contratuais aplicáveis) e, muitas vezes, estabelece obrigações alternativas à imposição de penalidades no âmbito de processos administrativos sancionadores. Justamente por ser uma forma de acordo, o TAC restringe-se àqueles casos que envolvem direitos disponíveis.

No caso concreto, o TAC poderia detalhar quais medidas complementares de segurança poderiam ser incorporadas ao contrato de comodato estabelecido pela associação e os associados, quais prazos seriam estipulados para a conclusão dos serviços necessários à obtenção do Alvará de Conclusão de Obra, dentre outros aspectos que poderiam ser discutidos pelas partes envolvidas.

No entanto, mesmo após essa argumentação e a declaração expressa das famílias dos caseiros sobre o fato de o conjunto não possuir "habite-se", a Caixa não aceitou a proposta do TAC e decidiu pela penalização da entidade, colocando-a no CONRES (cadastro interno restritivo da Caixa), que a impede de celebrar novos contratos com o banco durante o tempo que perdure a restrição.

\subsection{Desenvolvimento de obra}

$\mathrm{Na}$ autogestão, como o movimento não possui um capital próprio, como ocorre com as construtoras, é necessário que a parcela de recursos necessários para execução de cada etapa seja antecipada para as compras de material, contratação de trabalhadores e serviços. Após a execução, o movimento envia um relatório do serviço efetivamente executado ${ }^{81}$, o agente financeiro faz a vistoria no empreendimento e, caso seja verificado o andamento previsto, envia a solicitação de liberação de nova parcela financeira. Um dos aspectos levantado diversas vezes pelos movimentos de moradia é que esse trâmite levava, normalmente cerca de 15 dias e, caso houvesse algum fator intempestivo, até 60 dias. Nesse intervalo, entre o término da etapa e a efetiva liberação da próxima parcela financeira, a obra ficava sem recursos. Nesse sentido, fez parte da pauta de reivindicações dos movimentos

\footnotetext{
${ }^{81}$ Nos empreendimentos contratados junto à Caixa, esse relatório é denominado PLS (Planilha de Levantamento de Serviços).
} 
e foi instituído que haveria uma segunda antecipação de parcela financeira, logo após a verificação do início de obra, possibilitando que não houvesse interrupção no fluxo de recursos.

Na época do início da obra dos mutirões Florestan Fernandes e José Maria Amaral, a regulamentação do MCMV Entidades permitia essa forma de liberação, fazendo com que a obra sempre tivesse recursos em caixa para não interromper o andamento e também conseguir descontos nas compras de insumos e contratação de serviços, já que era possível fazer o pagamento à vista aos fornecedores. Além disso, era possível aplicar em fundos de investimento de curto prazo, os recursos que somente iriam ser gastos no mês seguinte. A premissa do programa era a realização de medições com intervalo mensal. No entanto, o andamento da obra acabou por não permitir a medição mensal, fazendo com que cada etapa levasse mais tempo do que o previsto.

A partir de dezembro de 2014, com a Instrução Normativa 39 publicada pelo Ministério das Cidades, a regra do programa foi alterada e não foi mais permitida a segunda antecipação. Os mutirões Florestan Fernandes e José Maria Amaral seguiram recebendo da forma anterior por certo tempo, por definição da própria Caixa, mas, sem informação prévia, tal dispositivo foi alterado, afetando o andamento da obra.

Outro elemento que reteve recursos e prejudicou o andamento da obra foi a retenção de recursos relacionados ao IPTU e ao recolhimento dos encargos trabalhistas.

Como foi descrito anteriormente, a área dos empreendimentos só teve seu IPTU lançado dois anos após a compra pelo movimento.

No entanto, para a obtenção da remissão dos valores lançados e da isenção do IPTU, o movimento precisou abrir um processo administrativo na Prefeitura de São Paulo, baseado na Lei municipal.15.360/2011, que levou mais de um ano para ser aprovado. Durante esse período, os valores equivalentes ao IPTU ficaram retidos nas liberações e só foram liberados quando a isenção foi enfim aprovada e os débitos cancelados. Cumpre dizer que o orçamento não incluía os valores para pagamento do IPTU tendo em vista a existência de legislação municipal que dava a isenção aos empreendimentos do MCMV.

Quanto aos encargos trabalhistas, é importante destacar que os normativos do programa determinam que a cada medição, a entidade deva apresentar a 
comprovação do recolhimento de $3 \%$ do valor liberado que seria o equivalente aos encargos trabalhistas da mão de obra necessária para a etapa de obra, segundo estimativa da Caixa. Caso não fossem entregues os comprovantes em valores suficientes, o agente financeiro glosava a diferença. No entanto, esse valor desconsidera a existência de mão de obra mutirante no canteiro, tratando toda a mão de obra necessária, como formalmente contratada e, portanto, devendo ter os encargos recolhidos da totalidade da mão de obra. Novamente, o normativo estava elaborado na perspectiva do regime de empreitada global e não para a autogestão e o mutirão. O movimento argumentou com a Caixa que essa medida era equivocada, já que o regulamento de obras em mutirão, apresentado na fase de contratação, previa as horas mensais de trabalho mutirante.

O caso foi levado ao Ministério das Cidades que afirmou só ser possível a mudança de entendimento com alguma resolução expressa da Previdência Social, pois o não recolhimento poderia pôr em risco a obtenção da CND (Certidão Negativa de Débitos), documento necessário para a legalização do conjunto e individualização das matrículas ao final da obra. A situação se estendia a todos os contratos que contavam com mão de obra mutirante, mas nunca houve resposta da Previdência Social.

Os mutirões Florestan Fernandes e José Maria Amaral chegaram a ter cerca de 600 mil reais glosados, causando mais atrasos à obra. Para a liberação desses recursos o movimento solicitou uma CND de obra inacabada, declarando os percentuais executados e apresentando o regimento de obras em mutirão. Após algumas negociações pontuais, a CND foi concedida e os recursos glosados foram liberados, sem que, no entanto, a questão tenha sido resolvida de forma definitiva.

A partir de março de 2016, o movimento identificou que haveria um desequilíbrio financeiro nas últimas etapas de obra devido ao tempo decorrido entre a elaboração do orçamento e a efetiva execução. Também identificou que, se no início de obra houve itens com significativo superávit, como na terraplanagem e fundação, já com $X \%$ de execução alguns itens se demonstraram deficitários. $O$ revestimento externo foi um desses itens, que consumiu boa parte dos recursos economizados nas etapas anteriores. 
Figura 37 - Vista panorâmica dos empreendimentos em 2016

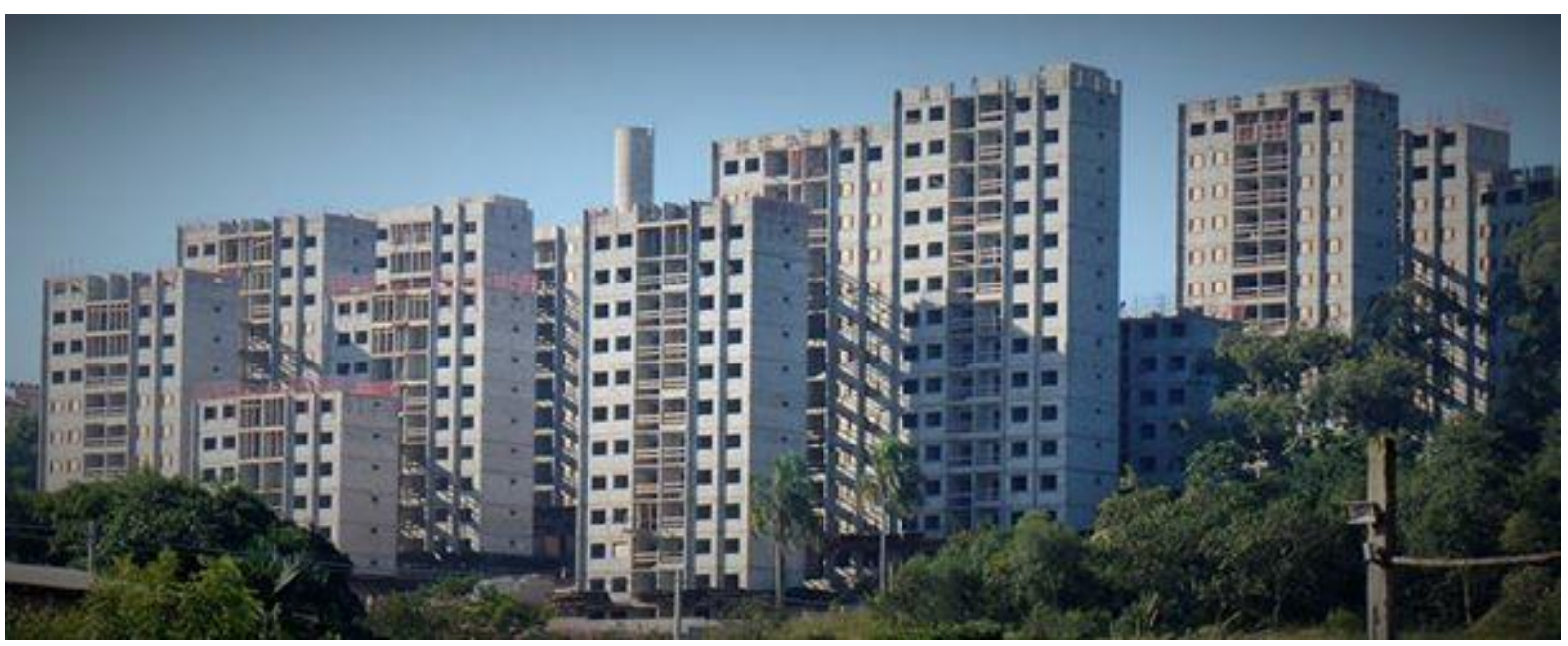

Fonte: Acervo do MST Leste 1

Com essa constatação, o movimento solicitou à Caixa a complementação dos valores desses itens, bem como a inclusão de novos itens no orçamento não previstos inicialmente, como mudanças no sistema de proteção de incêndio. Como o valor do FDS não teria como ser aditado, o movimento solicitou a liberação dos juros incidentes sobre o aporte do governo estadual, depositado integralmente na Caixa desde 2010 e que eram da ordem de $R \$ 2,2$ milhões.

O MST Leste 1 uniu-se a outros movimentos com situações semelhantes e reivindicou à Secretaria Estadual de Habitação e à Casa Paulista a utilização desse rendimento. Após manifestações e reuniões de negociação, a Secretaria concordou com a proposta desde que os movimentos apresentassem os orçamentos atualizados dos itens não incluídos anteriormente e uma justificativa para o pedido, que deveria ser anuída pelo agente financeiro. O MST Leste 1 apresentou a solicitação e os dados técnicos solicitados e a Caixa levou a solicitação à Casa Paulista. No entanto, como a Secretaria não respondia, novas manifestações foram feitas pelo movimento em conjunto com a UMM SP.

Nesse momento, a obra dos mutirões Florestan Fernandes e José Maria Amaral já apresentava muita dificuldade para seguir com seu andamento normal e atingir os percentuais para a medição. Dessa forma a obra foi paralisada, sendo mantidos apenas os custos fixos de canteiro. 
Figura 38 - Manifestação em defesa da liberação dos rendimentos do aporte

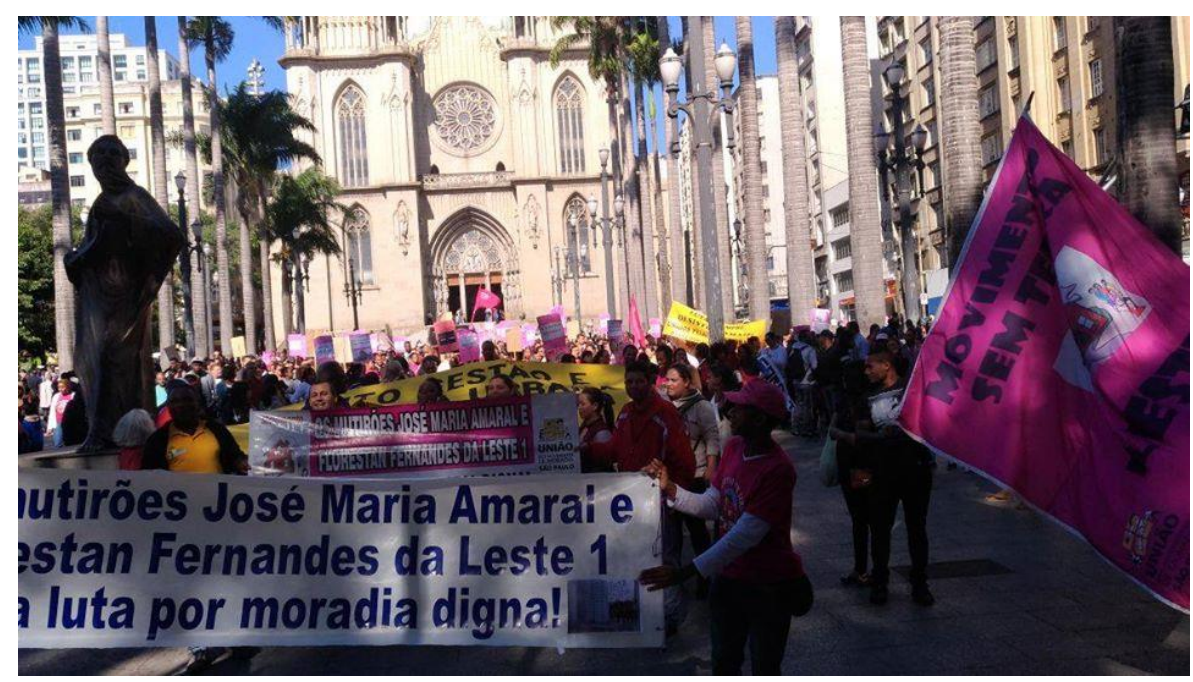

Fonte: Acervo do MST Leste 1

A Secretaria Estadual nunca chegou a dar uma resposta definitiva. Apenas alegava que havia um novo entendimento da Secretaria de Fazenda que impedia a liberação dos rendimentos e que estavam revendo a posição. Após mais de 6 meses sem resposta, o movimento decidiu mudar de estratégia, solicitando os mesmos valores à Prefeitura Municipal de São Paulo - Casa da Família - que não participava do empreendimento até então. A solicitação tramitou de forma relativamente ágil e, assim, a Prefeitura efetivou no início do $2^{\circ}$. Semestre de 2017 o aporte de $R \$$ 1.128.013,15 no José Maria Amaral e R\$1.112.708,82 no Florestan Fernandes, uma média de $\mathrm{R} \$ 5658,00$ por unidade habitacional. Isso possibilitou a retomada da obra embora ainda não fosse suficiente para a sua conclusão.

Em julho de 2019, novamente as liberações financeiras foram interrompidas por iniciativa do agente financeiro que exigia que o movimento demonstrasse que seria possível concluir a obra e também elaborasse um novo cronograma, com novos prazos.

Para o enfrentamento desse novo problema, novamente o movimento demonstrou o desequilíbrio financeiro comparando o valor orçado à época da contratação e o efetivamente executado. Considerando somente 0 valor do revestimento externo e telhado, os dois empreendimentos somaram $R \$ 679.000,00$ de déficit, o equivalente a $\mathrm{R} \$ 1.714,00$ por unidade habitacional. 
Tabela 10 - Desequilíbrio financeiro de itens de obra

\begin{tabular}{c|c|c|c}
\hline Item & Valor Orçado & $\begin{array}{c}\text { Valor de mercado } \\
\text { no momento da } \\
\text { execução }\end{array}$ & Déficit \\
\hline $\begin{array}{c}\text { Revestimento } \\
\text { externo }\end{array}$ & $\mathrm{R} \$ 807.000,00$ & $\mathrm{R} \$ 1.323 .000,00$ & $\mathrm{R} \$ 516.000,00$ \\
\hline Telhado & $\mathrm{R} \$ 177.000,00$ & $\mathrm{R} \$ 340.000,00$ & $\mathrm{R} \$ 163.000,00$ \\
\hline
\end{tabular}

Fonte: Ofício do MST Leste 1, 2019

Além disso o movimento construiu junto à coordenação e a Ambiente algumas alternativas que se somaram para viabilizar a conclusão da obra.

A primeira delas foi a atualização do orçamento dos itens faltantes e do cronograma para o término de obra, estabelecendo um percentual menor a ser realizado mensalmente, porém mais factível para essa etapa de obra. Também elaborou uma nova solicitação à Prefeitura para complementar em $R \$ 281,00$ por unidade, o aporte já feito, em itens ainda não executados e não incluídos em solicitações anteriores. As famílias mutirantes assumiram duas contrapartidas, a primeira delas seria na colocação efetiva de itens no próprio apartamento, como tanque, pia, vaso sanitário e acessórios. Além disso, foi feito um rateio dos valores orçados que excediam o levantamento feito. As famílias assumiram mais essa contrapartida, que ainda se encontrava em implementação no final de 2019.

Ainda que essas iniciativas tenham sido apresentadas ao agente financeiro em setembro de 2019 e a retomada das liberações fosse autorizada formalmente após manifestação na Caixa, em novembro, nova liberação financeira somente ocorreu no final de janeiro de 2020, atrasando, mais uma vez, o cronograma aprovado. Em março de 2020, o Mutirão Florestan Fernandes contava com 92,28 \% de obras executadas e o Mutirão José Maria Amaral com 95,21 \%.

Outro elemento que provocou parte dos atrasos foi a eletrificação do conjunto. Durante o período de obras houve algumas alterações dos normativos relacionados ao papel das concessionárias nos empreendimentos de habitação de interesse social. A Resolução oㅜ 414/2010 da Aneel (Agência Nacional de Energia Elétrica) e suas alterações previam que a distribuidora era

"a responsável pelos investimentos necessários e pela construção das redes e instalações de distribuição de energia 
elétrica para 0 atendimento das unidades consumidoras situadas em empreendimentos habitacionais para fins urbanos de interesse social e na regularização fundiária de interesse social ${ }^{82 "}$.

No entanto, essa disposição foi alterada em 2018, por meio da Resolução Normativa no $823 / 2018$, que tirou essa obrigatoriedade, mas os empreendimentos Florestan Fernandes e José Maria Amaral ainda faziam jus aos investimentos sob a responsabilidade da concessionária por terem tido suas solicitações protocoladas anterior à mudança da Resolução. A concessionária Eletropaulo fez diversas exigência e não havia aprovado o pedido até a sua venda para a empresa ENEL (Ente Nazionale per l'Energia Elétrica). Toda a tramitação teve que recomeçar e somente foi deferida no final de 2019, com prazo de 180 dias para a conclusão, após a cessão de servidão de passagem registrada na matrícula do imóvel, anuída pela Caixa, devido o terreno estar gravado com alienação fiduciária em garantia.

Com todas essas interrupções e atrasos, o grupo passou a ter mais conflitos e também ter um certo desânimo. Para enfrentar isso, a coordenação implementou algumas ações que, além de contribuírem para o avanço de obra, também buscavam recuperar o engajamento do grupo.

Uma delas foi a realização de alguns mutirões solidários, em que membros dos grupos de origem do movimento, que ainda não participavam de nenhum mutirão foram convidados a doar um dia de trabalho mutirante em atividades não especializadas. Foram feitos alguns dias de atividade de limpeza e plantio de grama nas áreas comuns, sempre acompanhadas de visitas ao empreendimento.

\footnotetext{
${ }^{82}$ Artigo 47 da resolução normativa nำ 414, de 9 de setembro de 2010 Agência Nacional de Energia Elétrica - ANEEL.
} 
Figura 39 - Mutirão Solidário com grupos de origem

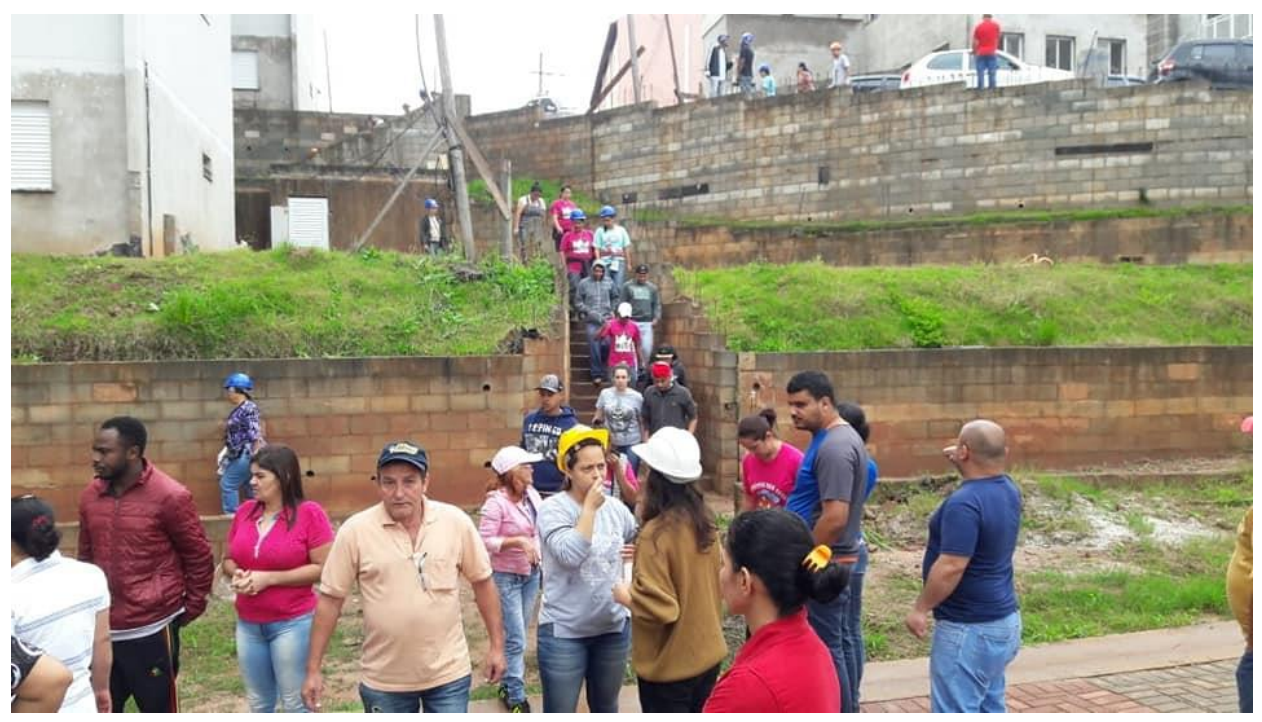

Fonte: Acervo do MST Leste 1

Figura 40 - Mutirão Solidário com grupos de origem

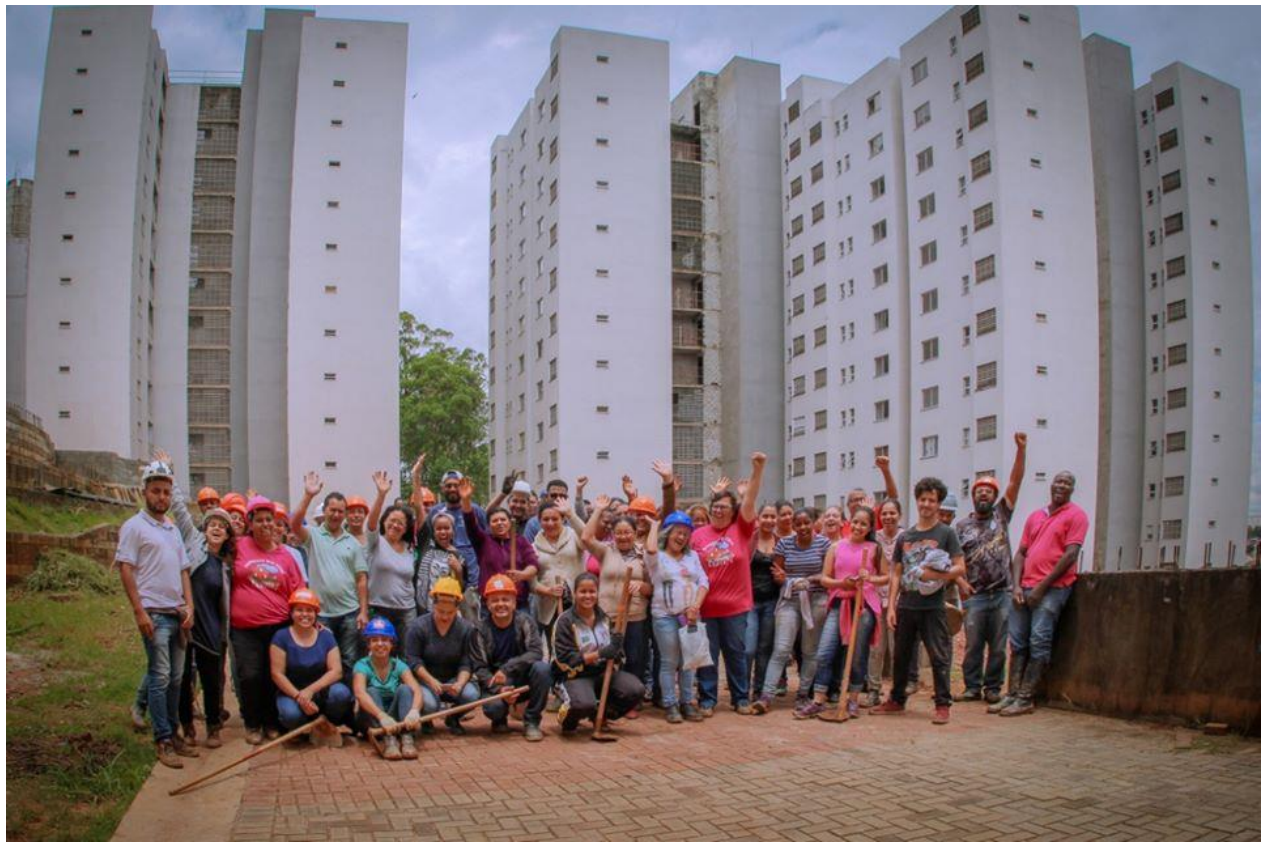

Fonte: Acervo do MST Leste 1

As comissões internas também se mobilizaram, com a venda de café da manhã e um bazar para angariar recursos para os gastos cotidianos do canteiro. Também foi realizado um bingo comunitário e uma festa de final de ano, com a participação de todos o movimento, em dezembro de 2019, com a renda revertida ao mutirão. 


\subsection{Associação de Moradores e Condomínio}

Uma das práticas comuns aos empreendimentos autogestionários é que todos os mutirantes trabalham igualmente em todo o conjunto, não sabendo de antemão qual unidade habitacional the será designada. Nos empreendimentos produzidos ou comercializados pelo poder público é bastante comum fazer o sorteio da unidade. Na autogestão, o critério de valorizar a participação se estende também para a escolha da unidade habitacional.

Nos empreendimentos Florestan Fernandes e José Maria Amaral havia apenas uma tipologia habitacional, com apenas uma variação da inclusão de uma janela a mais em metade das unidades. Nesse sentido, não houve a preferência por uma ou outra tipologia ou a sua relação com a composição familiar, o que ocorre quando há tipologias diferentes.

No final de 2017, já com cerca de $80 \%$ da obra executada, a coordenação propôs a realização da escolha dos apartamentos pelas famílias dos empreendimentos. Essa estratégia visava motivar o grupo que estava bastante desgastado com andamento da obra após a paralização em 2016 e também dava a possibilidade que as famílias já pudessem instalar alguns itens do apartamento que desejassem fora do padrão aprovado no orçamento da Caixa, sempre que instalassem algum item de qualidade superior. Esta estratégia acabou sendo ampliada em seguida, sendo alguns itens assumidos pelos mutirantes, como visto acima.

Para a realização da escolha, a comissão de pontuação sistematizou toda a participação das famílias desde o momento da sua entrada no grupo, que era, para parte das famílias, desde 2009. Além disso, todas as famílias deveriam estar quites com os dias de obra obrigatórios e com as contribuições financeiras para poder participar da hierarquização e escolha. Os mutirantes tiveram cerca de um mês para questionar a hierarquização publicada pela comissão e também para fazer uma visita guiada aos empreendimentos para definirem suas preferências de escolha.

Assim, na assembleia de dezembro de 2017, foi feito os processos de escolha, realizada em cada mutirão em uma data diferente. A assessoria preparou um material com a representação de cada um dos blocos e cada um dos apartamentos que possibilitava visualizar todo o conjunto. A partir da lista publicada, 
a coordenação chamava cada uma das famílias para escolher o seu apartamento e colocar uma etiqueta com a sua identificação.

As famílias escolhiam sua unidade a partir da localização do bloco e do andar preferido, mas também considerando os grupos de amigos formados durante a obra. A assembleia durou quase o dia todo, mas cada família fez sua escolha. Aqueles que pediram a palavra no momento da escolha, valorizavam o processo de participação e afirmavam que, em poucas ocasiões na vida, tiveram o poder de escolha respeitado. Mesmo as pessoas com posição inferior na hierarquização e que, portanto, tiveram menos opções de unidade habitacional para escolher, reconheceram a validade do processo.

Figura 41 - Atividade de escolha das unidades habitacionais

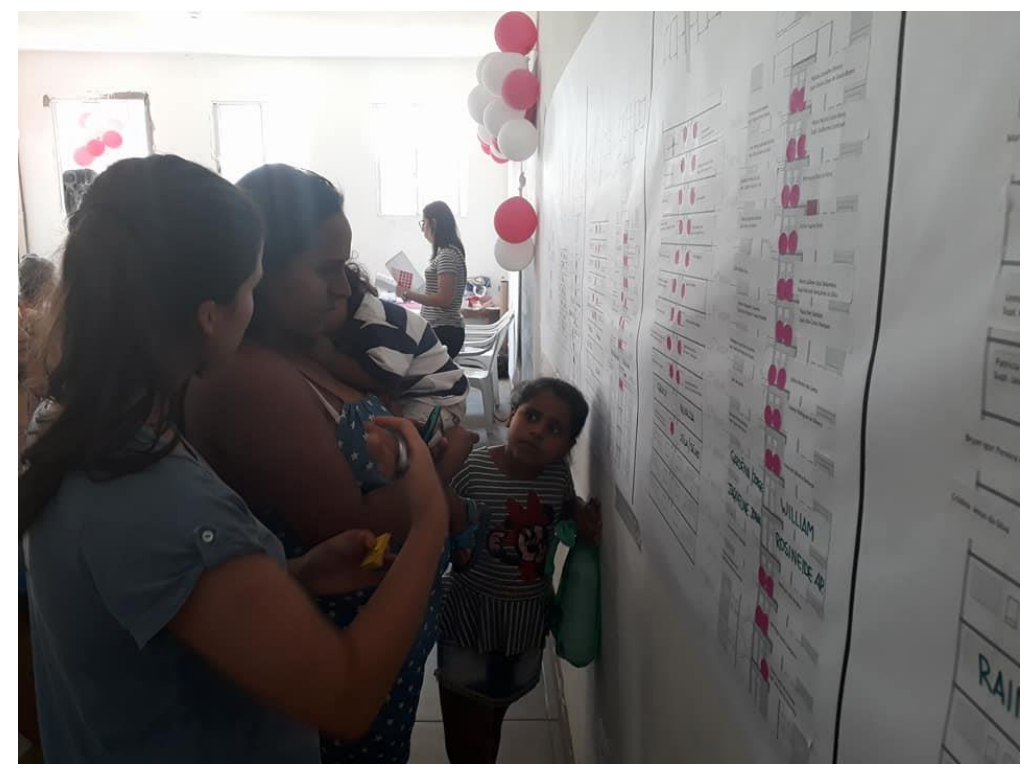

Fonte: Acervo MST Leste 1

A partir de 2018, o foco, além da conclusão da obra, passou a ser a organização do condomínio e das pós-ocupação.

A equipe de assessoria do trabalho social e a assessoria jurídica realizou um processo de formação sobre a organização do condomínio, contemplando os seus aspectos formais, a manutenção do empreendimento e a organização democrática para a convivência. Após essa formação, mesmo sem ainda a possibilidade de formalização do condomínio, a assembleia aprovou a convenção de condomínio.

Além disso, em setembro de 2019, assembleia elegeu a primeira gestão de cada um dos condomínios, que já passou a implementar as medidas aprovadas 
dentre as famílias que estão morando como caseiros na obra e assumindo a gestão da vida em comum.

Figura 42 - Centro comunitário

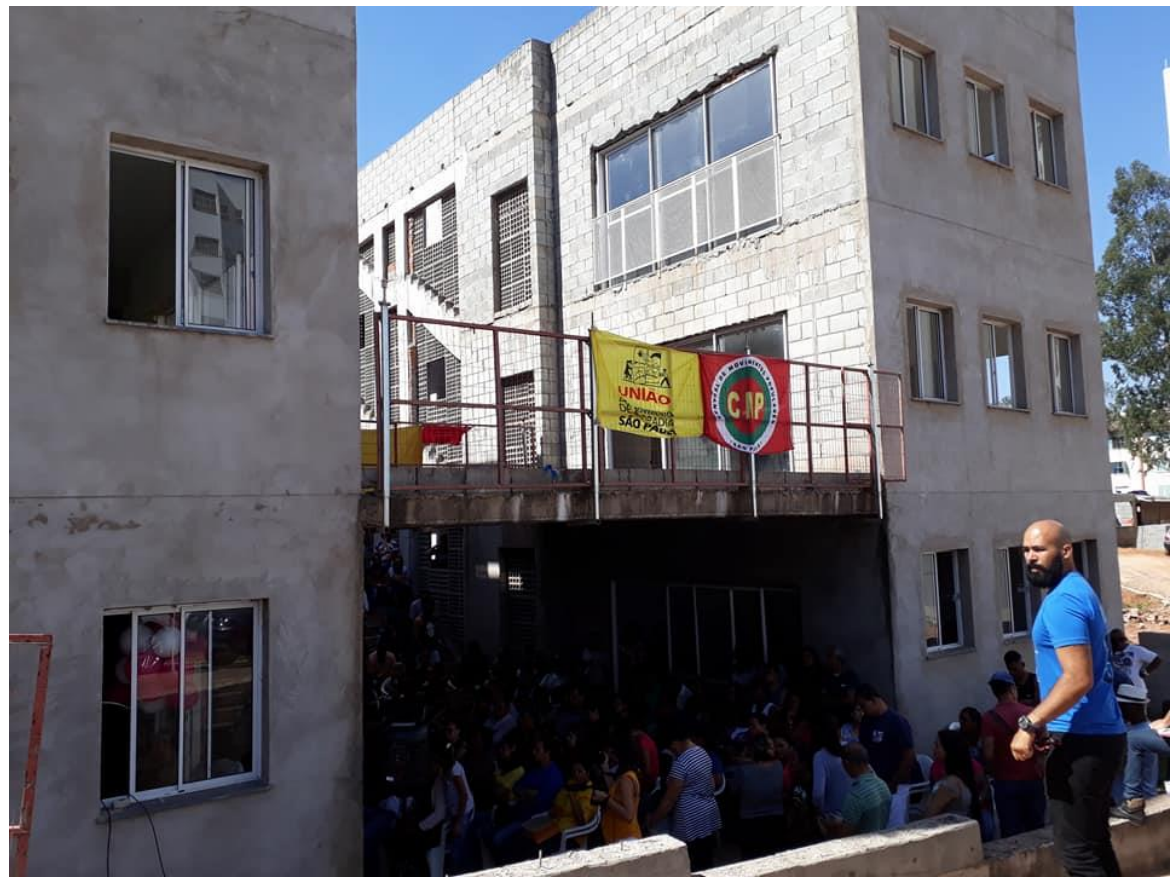

Fonte: Acervo do MST Leste 1

Além disso, um grupo de mutirantes passou a promover discussões sobre as necessidades dos futuros moradores frente aos desafios do bairro, bem como do uso a ser dado ao centro comunitário do conjunto. Apesar de formalmente se constituírem dois imóveis, na prática se trata de apenas um, com X metros quadrados e três andares e uma das discussões feitas pelo grupo é a realização de atividades com crianças e adolescentes nesse espaço, por meio de convênios com órgãos públicos ou parcerias com entidades sociais. Para essa finalidade, formou-se a Associação Semear - Leste 1, em uma figura jurídica distinta do condomínio, que já tem tido algumas iniciativas culturais ainda sem a conclusão do empreendimento. 


\section{6 - Considerações finais}

A dissertação se dispôs a produzir um diagnóstico do processo de institucionalização das propostas autogestionárias na produção habitacional no país e contribuir para o debate sobre a necessidade de construção de um marco jurídico abrangente e compatível com a característica transformadora da realidade social da qual a experiência é portadora.

$\mathrm{E}$, mesmo no cenário conflituoso em que se desenvolveram é possível destacar ganhos e avanços que transformam a vida dos que passam por esse processo.

Através de Singer (2010, p.106) é possível entender como a política do PT "Não era uma flexibilização e sim um verdadeiro mergulho no pragmatismo", e a forma como o partido se ajustou, implementando "simultaneamente, políticas que beneficiam o capital e promovem a inclusão dos mais pobres, com uma melhora relativa na situação dos trabalhadores" (p.110). Apesar das raízes sociais, as relações com suas bases eleitorais também mudaram, ficando essas embebidas do pragmatismo de alianças, mediações e sobreposições ideológicas.

Embora seja um grave equívoco desconhecer que o governo Lula cumpriu parte do programa histórico do partido ao estimular um mercado interno de massa, é verdade que, desconectados de uma postura anticapitalista, os ganhos materiais conquistados levam água para o moinho de um estilo individualista de ascensão social, embutindo valores de competição e sucesso (SINGER, 2010, p.108).

Ao mesmo tempo é possível relacionar limites e desafios para os quais o debate público é o meio eficaz para a sua superação.

Nos processos de produção social da moradia, prevalece a noção de moradia como direito e não como propriedade, o protagonismo dos cidadãos em detrimento dos interesses empresariais envolvidos, a diversidade de modalidades construtivas, entre outros aspectos.

Entretanto, tais processos, embora compatíveis com os fundamentos constitucionais, ainda carecem de um marco legal adequado que permita seu pleno desenvolvimento.

Neste contexto, a União Nacional por Moradia Popular, tem debatido o conjunto de premissas básicas que eventualmente podem ser estabelecidas num projeto de lei participativo e que mobilize a sociedade organizada na defesa da 
produção autogestionária da moradia. E dela, se pode tomar emprestado tais conceitos como ponto inicial para o debate necessário. A proposta em debate considera, dentre outros, os seguintes elementos:

Os canteiros das obras sob análise são administrados sob o regimento da administração direta, a tradução jurídica encontrada para denominar o que os movimentos sociais de moradia denominam autogestão na produção habitacional.

Os empreendimentos Florestan Fernandes e José Maria Amaral zelam com afinco pela observância da ampla participação dos associados em todas as decisões relevantes do processo de elaboração do projeto e execução da obra de modo que, por meio dos Estatutos Sociais, do Regulamento de Obras e da soberania assemblear têm buscado atender integralmente às normas do programa e, salvo melhor juízo, produziram, até o presente momento, um empreendimento de qualidade superior aquela que é desenvolvida historicamente no âmbito dos programas habitacionais públicos destinados ao atendimento de população de menor renda.

Entendida como uma forma de organização cujos elementos centrais são a pessoalidade e a finalidade não lucrativa o programa se baseiam na gestão democrática, que, no caso, concreto, orientou as decisões que foram tomadas no sentido de admitir a presença de associados e futuros moradores, desde a etapa da elaboração do projeto, no canteiro da obra, observadas, rigorosamente, as medidas de prevenção à acidentes e de segurança na obra.

O termo "mutirão", em termos etimológicos, remete a ideia de mobilização coletiva para auxílio mútuo em caráter gratuito. Ou seja, é o trabalho que reverte em favor dos próprios beneficiários.

Em termos práticos, significa que os associados participam concretamente da execução dos serviços em canteiro, manuseando ferramentas, aportando mão de obra e executando atividades próprias da área da construção civil. Ou seja, a presença dos associados no canteiro, não constitui novidade ou é motivo de qualquer controvérsia razoável. Não seria possível executar a obra em mutirão não fosse a presença ativa das famílias no canteiro.

Para regular o conjunto de obrigações que garante a segurança da iniciativa, os associados aprovaram um documento chamado "Regulamento de Obras", cujas regras devem ser fielmente observadas para o exercício do trabalho em canteiro. 
Além disso, conforme deliberação assemblear, os associados aprovaram a realização de uma vigília no canteiro que perdurou desde maio de 2013 até dezembro de 2018. Por meio da vigília, os associados guardaram o imóvel e o mantiveram seguro. Além disso, por meio da vigília, foi possível estabelecer uma relação respeitosa com a vizinhança, de modo que a guarda do terreno é feita no plano concreto pela vigília e no plano simbólico pelo nível de respeitabilidade que o projeto ganho na vizinhança, dada o grau de esforço dedicado pelos associados.

Garantia de acesso à moradia digna, conforme o Comentário Geral no 4 do Comitê dos Direitos Econômicos, Sociais e Culturais da ONU, o direito à habitação digna se confunde com o conceito de moradia adequada e reúne um conjunto de elementos, nenhum deles passíveis de serem desconsiderados, mas que no processo autogestionário podem ser realçados: A segurança da posse, a disponibilidade de serviços, materiais, instalações e infraestrutura, a economicidade, a habitabilidade, a acessibilidade e a localização tendem a ser mais bem preservados em processos controlados pelos futuros moradores e onde a lucratividade do empreendimento não seja o valor fundamental.

Estímulo ao associativismo e ao cooperativismo habitacionais, entendida como uma forma de organização cujos elementos centrais são a pessoalidade e a finalidade não lucrativa e considerando que sua atuação deve ser limitada aos empreendimentos pequenos e médios, não se admitindo nessa modalidade que o controle seja exercido por empresas capitalistas, caberia à proposta legislativa estabelecer um conjunto de princípios gerais para o enquadramento das propostas, tais como: posse coletiva dos meios de produção pelas pessoas que as utilizam para produzir; gestão democrática; o estímulo à participação direta dos futuros moradores; a soberania assemblear nos empreendimentos, dentre outros.

Estímulo à ajuda mútua o termo "mutirão", em termos etimológicos, remete a ideia de mobilização coletiva para auxílio mútuo em caráter gratuito. Ou seja, é o trabalho que reverte em favor dos próprios beneficiários. O trabalho mutirante deve ser estimulado por meio de sua clara caracterização legal, reconhecimento de benefícios tributários e outras estratégias.

Estímulo aos processos educacionais e pedagógicos de caráter emancipatório - Em linha com as lições de Paulo Freire, os processos pedagógicos e de trabalho social dos processos autogestionário devem reconhecer que para 0 oprimido o processo mais relevante é o da descoberta da sua situação de oprimido. 
Portanto, tais processos educativos partem do pressuposto de que somente o vivido é incorporado e utilizado em situações novas, por isso o saber sistematizado só terá relevância se for possível seu uso prático. A aprendizagem informal, via grupo e a negação de toda forma de repressão, visam a favorecer o desenvolvimento de pessoas mais livres e capazes de contribuir com a sustentabilidade do empreendimento mesmo posteriormente à conclusão das obras. Não se trata apenas de produzir moradia, mas contribuir para a formatação de novas consciências.

Direito à assessoria técnica especializada, nesse ponto o que se propõe é a recuperação do caráter não lucrativo das entidades de assessoria técnica, cuja atuação deve compreender a sua natureza interdisciplinar, envolvendo o trabalho de arquitetos, engenheiros, advogados, profissionais das diversas formações humanísticas, de modo a favorecer o desenvolvimento de uma técnica reprodutora da autonomia dos futuros moradores.

Estímulo às formas coletivas de fruição do uso, da posse ou da propriedade das unidades habitacionais com o debate da propriedade coletiva dos espaços construídos coletivamente deve ser realizado com os futuros moradores na perspectiva da superação do padrão da propriedade individual da terra e da moradia. A propriedade pode ser vista sobre um prisma contemporâneo, que, pode ser sintetizada como uma relação jurídica complexa, um feixe de direitos e obrigações recíprocas entre os titulares e destes para com a sociedade.

Lembrando David Harvey (2004, p.307), "Ao mudar nosso mundo, mudamos a nós mesmos". Assim, tais potencialidades e aprendizagem podem, em primeira instância, não parecer estruturantes, como uma política nacional, mas podem reconfigurar espaços periféricos. Por isso, a intenção do mutirão em ser uma via de comunhão, mesmo que contraditória, ainda perdura. As trocas e vínculos fortes decorrentes dos momentos de trabalho em ajuda mútua fizeram com que esse espaço fosse mantido, apesar das críticas.

O mutirão pode ser o início de uma transformação na sociabilidade daquele grupo, fruto de uma ação social, que começa de baixo para cima e ganha forças nas periferias, estimulando uma solidariedade popular, que se mantém através da reciprocidade das redes interdependentes, podendo alcançar patamares mais distantes a cada novo espaço coletivo construído. 


\section{REFERÊNCIAS BIBLIOGRÁFICAS}

AMARAL, Ângela de Arruda Camargo. Habitação na cidade de São Paulo, $2^{a}$ ed. (revisada). São Paulo: Polis/PUC-SP, 2002.

ARRETCHE, Marta. A descentralização como condição de governabilidade: solução ou miragem?. In: Espaço e Debates: Revista de Estudos Regionais e Urbanos. № 39. São Paulo, 1996.

BARAVELLI, José. O cooperativismo uruguaio na habitação social de São Paulo: Das cooperativas FUCVAM à Associação de Moradia Unidos de Vila Nova Cachoeirinha. Dissertação de Mestrado, FAUUSP, São Paulo, 2006;

BARBAGALLO, José. MOI Movimiento de Ocupantes e Inquilinos en movimento: la lucha por la casa en la ciudad de Buenos Ayres: una experiencia autogestionaria. Buenos Ayres: Associación Civil, 2007.

BELATO, Clara Silveira; LAGO, Luciana Corrêa do. Propriedad y derecho de uso del suelo urbano no Brasil. In: La vivenda, entre el derecho y la mercancia: las formas de propriedade en América Latina. Centro Cooperativo Suéco/Programa Regional de Vivienda y Hábitat, Montevideo, 2014.

BLIKSTAD, Karin. O agir coletivo nas interfaces da sociedade civil e do sistema político: o caso da atuação do movimento de moradia de São Paulo sobre a política pública de habitação. Dissertação de Mestrado. Campinas: Universidade Estadual de Campinas.

BLIKSTAD, Karin; TATAGIBA, Luciana; TEIXEIRA; Movimentos sociais na implementação de programas federais: reflexões a partir do MCMV-E. Anais do 39을 Encontro Anual da ANPOCS. CAXAMBU, MG, 2015. Disponível em: https://anpocs.com/index.php/encontros/papers/39-encontro-anual-da-anpocs. Acesso em 28/12/2019.

BOCAYUVA, Pedro Cláudio Cunca. As metamorfoses do trabalho e da cooperação produtiva: a economia popular e solidária na perspectiva da nova centralidade do trabalho. Rio de Janeiro: FASE, 2007.

BONAVIDES, Paulo. Do estado liberal ao estado social. 8. ed. São Paulo, Malheiros, 2007.

BONDUKI, Nabil. Habitação e autogestão: Construindo territórios de utopia. Rio de Janeiro: Federação de Órgãos para Assistência Social e Educacional - FASE, 1992; 
Habitar São Paulo: reflexões sobre a gestão urbana. São Paulo: Estação Liberdade, 2000.

Autoconstrução e habitação: reflexões sobre a contribuição de -

Chico de Oliveira. In.: RISEK, Cibele Saliba; ROMÃO, Wagner de Melo. (Orgs.) Francisco de Oliveira. A tarefa da crítica. Belo Horizonte: Editora UFMG, 2006. In: Autoconstrução e habitação: memória e reflexões sobre a contribuição de Chico de Oliveira.

. Os pioneiros da Habitação Social: Cem anos de política urbana no Brasil. Vol 1. São Paulo: Editora Unesp: Editora SESC, 2014;

BONDUKI, Nabil e ROSSETTO, Rossella. A luta pela reforma urbana no Brasil: Do seminário de Habitação e Reforma Urbana ao Plano Diretor de São Paulo, São Paulo: Instituto Casa da Cidade, 2018.

BUCCI, Maria Paula Dallari. Cooperativas de Habitação no Direito Brasileiro. São Paulo: Saraiva, 2003.

BUCCI, Maria Paula Dallari. (Org.). Política Pública: reflexões sobre o conceito jurídico. In: O Conceito de Política pública em Direito. São Paulo: Saraiva, 2006, p.39.

CALDEIRA, Clovis. Mutirão: formas de ajuda mútua no meio rural. São Paulo: Companhia Editora Nacional, 1956.

CAMARGO, Camila Moreno. Minha Casa Minha Vida Entidades: entre os direitos as urgências e os negócios. Tese de Doutorado. IAU/USP, São Carlos, 2016;

CARDOSO. Fernanda Simon; SANTO AMORE. Caio. Assessoria e assistência técnica para habitação de interesse social no Brasil. Anais do XV Colóquio internacional de Geocrítica. Barcelona, 2018. Disponível em: http://www.ub.edu/geocrit/XV-Coloquio/CardosoAmore.pdf. Acesso em 28/12/2019. CARVALHO, Caio Santo Amore de. A lupa e o telescópio - o mutirão em foco. São Paulo, anos 90 e atualidade. Dissertação de Mestrado. FAU/USP, São Paulo, 2004; Assessoria e Assistência Técnica: arquitetura e comunidade na política pública de habitação de interesse social. In: II Seminário Nacional sobre urbanização de Favelas, 2016, Rio de Janeiro. Anais do II URBFAVELAS. Rio de Janeiro: Letra Capital, 2016.

CAVALCANTI. Gustavo Carneiro Vidigal. Uma concessão ao passado: trajetórias da União dos Movimentos de Moradia de São Paulo. São Paulo. Dissertação de 
mestrado. Faculdade de Filosofia, Letras e Ciências Humanas da Universidade de São Paulo. São Paulo, USP, 2006.

COMPARATO, Fábio Conder. O direito e o avesso. Estudos Avançados. vol. 23 nº.67,. São Paulo, 2009. Disponível em: https://doi.org/10.1590/S010340142009000300002. Acesso em 12/01/2020.

CONFORTO, Paulo. (entrevista realizada por Ana Amélia da Silva). In: SILVA, Ana Amélia (org.). Moradia e Cidadania: um debate em movimento. São Paulo: Pólis, 1994.

CONFORTO, Paulo; RODRIGUES, Domingos Pereira. Ocupar não é invadir: a ocupação como forma de luta. In:; BALTRUSIUS, Nelson; PALUMBO, Adriana Posi; PEREIRA, Marcia Acorsi; Direito à moradia: uma contribuição ao debate. São Paulo: União dos Movimentos de Moradia/Federação de órgãos para assistência social e educacional/Paulinas, 1992.

CONSTANTINO, Carlos Adriano Santos. A COHAB-SP e uma nova política habitacional: o período 2001-2004. Dissertação de Mestrado. FAUUSP. São Paulo, 2007;

COUTO, C. (1995). O desafio de ser governo: o PT na Prefeitura de São Paulo. Rio de Janeiro: Paz e Terra, 1996.

DENIZO, Valentina. Os produtos da política estadual de habitação da Região Metropolitana de São Paulo: elementos para a análise de uma política metropolitana de habitação. Tese de Doutoramento apresentada à Faculdade de Arquitetura e Urbanismo da Universidade de São Paulo. 2007.

D’ALESSANDRO, Maria Lucia S.; MILANESI, Renata; Mutirões autogestionários: levantamento das obras - 1989 a 1995. São Paulo: FASE, s/d.

DARDOT, Pierre; LAVAL, Cristian. Propriedade, apropriação social e instituição do comum. Tempo Social, 27. pgs. 261-273. 2015. Disponível em: http://www.scielo.br/pdf/ts/v27n1/0103-2070-ts-27-01-00261.pdf. Acesso em 28/12/2019.

DICKMANN, Ivânio. O sonho coletivo da casa própria: a articulação da economia solidária com a educação popular no cooperativismo habitacional autogestionário. Dissertação de Mestrado apresentada à Faculdade de Serviço Social da Pontifícia Universidade Católica de São Paulo. São Paulo, 2018. 
DOIMO, Ana Maria. A vez e a voz do popular: movimentos sociais e participação política no Brasil pós-70. Rio de Janeiro: Relume-Dumará, 1995.

FARAH, Marta Ferreira Santos. Inovação e governo local no Brasil comtemporâneo. In: Jacobi, Pedro; José Antônio Pinho. Inovação no campo da gestão pública local: novos desafios, novos patamares. Rio de Janeiro: FGV, 2006.

FASE (Federação de Órgãos para Assistência Social e Educacional), IAF - Inter American Foudation - Mutirões Autogestionários - Levantamento de Obras 1989 a 1995. ed. Forja Gráfica. São Paulo, sem data;

FELIPE, Joel. Mutirão e autogestão no Jardim São Francisco (1989- 1992). Dissertação de Mestrado FAUUSP: São Carlos, 1997;

FERREIRA. Francisco Whitacker. Participação popular, inovação promissora da Constituinte de 1987-1988 e os tempos atuais. In: 30 anos da Constituição Brasileira: Democracia, Direitos Fundamentais e Instituições. José Antônio Dias Toffoli (Org.). Rio de Janeiro: Forense, 2018.

FERREIRA. João Sette Whitacker. Mito da cidade-global: o papel da ideologia na produção do espaço terciário em São Paulo. São Paulo: UNESP, 2007.

FERREIRA. Regina Fátima Cordeiro Fonseca. A autogestão habitacional no Brasil a partir do governo Lula: produção e agentes. In: Lago, L.C. Autogestão no Brasil: utopias e contradições. Rio de Janeiro: Letra Capital, 2012.

Autogestão e habitação: entre a utopia e o mercado. Tese de Doutorado. Rio de Janeiro: IPPUR/UFRJ, 2014.

FLORES, Enrique Ortiz. El camino possible: producción social del hábitat en América Latina. San José: Centro Cooperativo Suéco/TRILCE, 2011.

GOHN. Maria Marcondes da Glória. Movimentos Sociais e luta pela moradia. São Paulo: Edições Loyola, 1991.

. Assessoria e movimentos populares: História, avaliação e significado político. In: Revista Educação e Realidade. Vol. 16, no 01, jan-jun,1991.

. Movimentos Sociais e construção da Cidadania. Palestra realizada em 22 de novembro de 2000, na mesa redonda "Movimentos Sociais e educação, no Seminário Educação 2000, promovido pelo Instituto de Educação e o Programa de Pós Graduação em Educação da Universidade Federal de Mato Grosso. Disponível em: https://www.ufmt.br/revista/arquivo/rev19/gohn 1.htm. Acesso em 22/11/2019.

GOMES, Marcos Pinto Correia. $\underline{0}$ direito social à moradia e os municípios brasileiros. Revista Jus Navigandi, ISSN 1518-4862, Teresina, ano 10, $\underline{\text {. }}$ 
900, 20 dez. 2005. Disponível em: https://jus.com.br/artigos/7746. Acesso em: 5 abr. 2020.

GOMIDE, Alexandre de Ávila; PIRES, Roberto Rocha Coelho. Governança e capacidades estatais: uma análise comparativa de programas federais. In: Rev. Sociol. Polit., v. 24, n. 58, p. 121-143, jun. 2016. Disponível em: http://www.scielo.br/pdf/rsocp/v24n58/0104-4478-rsocp-24-58-0121.pdf. Acesso em 02.01/2020.

GUARITÁ, Gabriela Darini. O valor do dinheiro no tempo: uma avaliação de empreendimentos do Programa Minha Casa Minha Vida - Faixa 1. São Paulo: Dissertação de Mestrado. FAUUSP, 2018.

IFFLY, Catherine. Transformar a metrópole: igreja católica, territórios e mobilizações sociais em São Paulo 1970-2000. São Paulo: Editora UNESP, 2010.

JESUS. Patricia Maria de. O Programa Minha Casa Minha Vida - Entidades no Município de São Paulo. Tese de Doutorado. São Paulo: FFLCH/USP, 2015.

KONTA, Ryohei. Participação nos movimentos de moradia em São Paulo: agência, estrutura e institucionalização. São Paulo: Curitiba: CRV, 2018.

LAGO, Luciana Corrêa do. (Org.) Autogestão habitacional no Brasil: utopias e contradições. Rio de Janeiro: Letra Capital, 2012.

LOPES, João Marcos e RIZEK, Cibele S. O mutirão autogerido como procedimento inovador na produção da moradia para os pobres: uma abordagem crítica. In: Coletânea Habitare - Vol. 5 - Procedimentos de Gestão Habitacional para População de Baixa Renda, 2005, p. 44-75;

LOPES, João Marcos de Almeida. Nós, os arquitetos dos Sem Teto. Revista Brasileira de Estudos Urbanos e Regionais. São Paulo. V.20, no .2, p.237-253, MaiAgo, 2018.

LOUREIRO, Isabel; SINGER, André. As contradições do lulismo: a que ponto chegamos? São Paulo: Boitempo, 2016.

MARICATO, Erminia. (org). A produção capitalista da casa (e da cidade) no Brasil industrial. Alfa Omega , 1979;

. MARICATO, Ermínia. O Ministério das Cidades e a política urbana no Brasil: quais as ações do Ministério desde sua criação, os problemas e desafios enfrentados. In: Revista AU - Arquitetura e Urbanismo, o 156. São Paulo: PINI, março de 2007, pp. 64-65. Disponível em: <http://www.revistaau.com.br/arquiteturaurbanismo/156/artigo44395-1.asp >. Acesso em: 15/04/2020. 
As tragédias urbanas: desconhecimento, ignorância ou cinismo? In: Vitruvius. n. -199.04 . Cidades do Brasil. Ano 11, abril de 2011. Disponível em: https://www.vitruvius.com.br/revistas/read/minhacidade/11.129/3795. Acesso em 23.11.2019.

Política Habitacional no Regime Militar: do milagre brasileiro à crise econômica. Petrópolis: Vozes, 1987; MIAGUSKO, Edson. Movimentos de moradia e sem teto em São Paulo. Tese de Doutorado. FFLCH USP. São Paulo, 2008;

MENDES, Michele Diniz. (Coord.) Marco regulatório das organizações da sociedade civil: de acordo com a Lei no 13.019/2014 que instituiu o Marco Regulatório das Organizações da Sociedade Civil (MROSC). Belo Horizonte: Fórum, 2017. MINEIRO, Edilson e RODRIGUES, Evaniza. e. Do Crédito Solidário ao Minha Casa Minha Vida Entidades: uma história em construção. In: LAGO, L. (org.).Autogestão habitacional no Brasil: utopias e contradições. Rio de Janeiro: Letra Capital, 2012; MINEIRO, Edilson Henrique. Os dilemas jurídicos da produção autogestionária de habitação de interesse social. In: Revista Brasileira de Direito Urbanístico. Ano 3, no 4. Belo Horizonte: Fórum, 2017.

MOREIRA, Fernanda Accioly. O lugar da Autogestão no Governo Lula. Dissertação (Mestrado - Área de Concentração: Habitat) - Faculdade de Arquitetura e Urbanismo da Universidade de São Paulo, São Paulo, 2009;

NAHOUN, Benjamin. El movimento cooperativista del Uruguay, autogestión, ayuda mutua, aporte próprio, propriedade colectiva. In: Cooperativas de vivienda em Uruguay: medio siglo de experiências. São Paulo: Governo do Estado de São Paulo/Museu da Casa Brasileira, 2015.

NASCIMENTO, Cláudio. A Autogestão e o "Novo Cooperativismo". Texto para discussão. MTE: Brasília, 2004.

Cláudio. Autogestão e Economia Solidária. Disponível em $<$ http://www.tau.org.ar/upload/89f0c2b656ca02ff45ef61a4f2e5bf24/nascimento auto gest.pdf >. Acesso em 28/12/2019.

NICOLADELI, Sandro Lunard. Direito e autogestão: a solidariedade como elemento indutor de outra economia. Curitiba: Instituto Memória, 2009.

OLIVEIRA, Francisco de. Crítica à razão dualista/O ornitorrinco. São Paulo, Boitempo, 2003. [artigo publicado originalmente na em: Estudos CEBRAP oํ 01, em 1975 e transformado em livro pela editora Vozes em 1981]. 
FLORES ORTIZ. Henrique. Produción social de vivenda y habitat: bases conceptuales ara uma política pública. In: Producción social de vivienda y hábitat: bases conceptuales para una política pública. In ARÉBALO, Marta et al. El camino posible. La producción social del hábitat en América Latina. Montevidéu: Ediciones Trilce, 2011.

PAZ. Rosangela Dias Oliveira da. Fundo Nacional de Moradia Popular: Marco Histórico de Participação da União dos Movimentos de Moradia de São Paulo. Dissertação de Mestrado. São Paulo: Pontifícia Universidade de São Paulo, 1996.

PREFEITURA MUNICIPAL DE SÃO PAULO, Balanço de Governo da Secretaria Municipal de Habitação - 2013 a 2016, São Paulo, 2016.

RAMOS, Lélia Amanda de Carvalho. A participação popular no exercício das políticas públicas habitacionais como fator de influência no produto habitacional construído e apropriado. Dissertação de Mestrado. FAUUSP, 2007.

RIZEK, Cibele Saliba. O Programa minha casa minha vida entidades: provisão de moradia no avesso da cidade? In: Revista Cidades, Vol. 11, № 19 : processos extremos na constituição da cidade. Diponível em: http://revista.fct.unesp.br/index.php/revistacidades/article/viewFile/4283/3249. Acesso em 29/12/2019.

RIZEK, Cibele Saliba; SANTO AMORE, Caio; CAMARGO, Camila Moreno. Política habitacional e políticas sociais: urgências, direitos e negócios. In: A cidade como negócio[S.I: s.n.], 2015.

RICCI, Rudá. Lulismo. Da era dos movimentos sociais à ascensão da nova classe média brasileira. Brasília: Fundação Astrojildo Pereira, 2010.

RIZEK, C. S. O Programa Minha Casa Minha Vida Entidades: provisão de moradia no avesso da cidade? Cidades, São Paulo, v. 11, n. 19, 2014, p. 236-264.

RIZEK, Cibele; BARROS, Joana; BERGAMIM, Marta. A política de produção habitacional por mutirões autogestionários: construindo algumas questões. RBEUR, 2003;

RIZEK, Cibele; SANTO AMORE, Caio; MORENO, Camila; CASTRO, Andrea;

RODRIGUES. Evaniza Lopes. A estratégia fundiária dos movimentos populares na produção autogestionária da moradia. Dissertação de Mestrado. FAUUSP. São Paulo, 2013.

RODRIGUES, Evaniza Lopes et. al, Revista da Produção de Habitação em Autogestão, São Paulo, União Nacional por Moradia Popular, 2019, 
RODRíGUEZ, Maria Carla. Autogestión, políticas del hábitat y transformación social. Buenos Aires: Espacio editorial, 2009.

ROLNIK, Raquel. A cidade e a lei: legislação, política urbana e territórios na cidade de São Paulo. 3a ed. São Paulo: Studio Nobel/FAPESP, 2003.

Guerra de lugares: a colonização da terra e da moradia na era das finanças. São Paulo: Boitempo, 2015.

RONCONI, Reginaldo. Habitações construídas com o gerenciamento pelos usuários, com organização da força de trabalho em regime de mutirão (O Programa Funaps Comunitário). Dissertação de Mestrado. Escola de Engenharia de São Carlos, USP. São Paulo, 1995;

ROSSETTO, Rossella. Fundo Municipal de Habitação. São Paulo: Instituto Pólis/PUC-SP, 2003;

ROYER, Luciana de Oliveira. Política Habitacional do Estado de São Paulo: Estudo sobre a Companhia de Habitação e Desenvolvimento Urbano, CDHU. Dissertação de Mestrado. FAUUSP. São Paulo, 2002.

SAULE JÚNIOR, Nelson; UZZO, KARINA. A trajetória Movimento Nacional pela Reforma Urbana. Disponível em: http://www.redbcm.com.br/arquivos/Bibliografia/a\%20trajectoria\%20n\%20saule\%20k \%20uzzo.pdf. Acesso em 23/11/2019.

SILVA, José Afonso da. Aplicabilidade das Normas Constitucionais. São Paulo: Malheiros, 1998.

SINGER, Paul. Um governo de esquerda para todos: Luiza Erundina na Prefeitura de São Paulo (1989- 1992). São Paulo: Brasiliense, 1986. . Introdução à economia solidária. São Paulo, Fundação Perseu Abramo, 2002.

SUNDFELD, Carlos Ari. O Estatuto da Cidade e suas diretrizes gerais. In: Estatuto da Cidade: comentários à Lei Federal oㅜ 10.257/2001. 3ª ed. São Paulo: Malheiros, 2010.

TATAGIBA, Luciana; TEIXEIRA, Ana Claudia; Efeitos combinados dos movimentos de moradia sobre os programas habitacionais autogestionários. Revista Sociologia e Politica. vol. 24 n‥ 58. Curitiba, Junho de 2016.

Avaliação do Programa Minha Casa Minha Vida - Entidades. O desafio da participação dos beneficiários. Campinas: Núcleo de Pesquisa em 
participação, movimentos sociais e ação coletiva da Universidade Estadual de Campinas, 2015.

TEIXEIRA, Wendel de Brito Lemos. Associações civis. $4^{\mathrm{a}}$ ed. Belo Horizonte: Del Rey, 2014.

\section{Legislação consultada:}

Municipais

MUNICÍPIO DE SÃO PAULO. Lei no 13.433 , de 27 de setembro de 2002. Dispõe sobre o Serviço de Assessoria Técnica em Habitação de Interesse Social, autoriza o Executivo a celebrar convênios e termos de parceria e dá outras providências.

MUNICÍPIO DE SÃO PAULO. Lei no 16.050 , de 31 de julho de 2014. Aprova a Política de Desenvolvimento Urbano e o Plano Diretor Estratégico do Município de São Paulo e revoga a Lei no 13.430/2002.

MUNICÍPIO DE SÃO PAULO. Lei ํo0, de 04 de abril de 1990. Lei Orgânica do Município.

MUNICÍPIO DE SÃO PAULO. Lei no 16.587, de 12 de dezembro de 2016. Dispõe sobre a autogestão na moradia.

MUNICÍPIO DE SÃO PAULO. Lei oํ 8.906, de 27 de abril de 1979. Dispõe sobre a criação do Fundo de Atendimento à População Moradora em Habitação Subnormal - FUNAPS e dá outras providências.

MUNICÍPIO DE SÃO PAULO. Lei no 15.764 , de 27 de maio de 2013. Dispõe sobre a criação e alteração da estrutura organizacional das Secretarias Municipais que especifica, cria a Subprefeitura de Sapopemba e institui a Gratificação pela Prestação de Serviços de Controladoria.

MUNICÍPIO DE SÃO PAULO. Lei no 11.632, de 22 de julho de 1994. Dispõe sobre o estabelecimento de uma política integrada de habitação, voltada à população de baixa renda; autoriza a instituição, junto à Companhia Metropolitana de Habitação de 
São Paulo - COHAB/SP, do Fundo Municipal de Habitação; cria o Conselho do Fundo Municipal de Habitação, e dá outras providências.

MUNICÍPIO DE SÃO PAULO. Lei o 13.425, de 02 de setembro de 2002. Regulamenta o artigo 168 da Lei Orgânica do Município de São Paulo e institui o Conselho Municipal de Habitação de São Paulo.

MUNICÍPIO DE SÃO PAULO. Lei no 13.509, de 10 de janeiro de 2003. Altera a Lei № 11.632, de 22 de julho de 1994, que dispõe sobre o estabelecimento de uma política integrada de habitação, voltada à população de baixa renda; autoriza a instituição, junto à Companhia Metropolitana de Habitação - COHAB/SP, do Fundo Municipal de Habitação; cria o Conselho do Fundo Municipal de Habitação, e dá outras providências.

\section{Estaduais}

SÃO PAULO. Lei oㅜ 6556, de 1 de dezembro de 1989. Dispõe sobre alíquotas do Imposto sobre Operações Relativas à Circulação de Mercadorias e sobre Prestações de Serviços de Transporte Interestadual e Intermunicipal e de Comunicação - ICMS e dá outras providências.

SÃO PAULO. Lei no 6757, de 14 de março de 1990. Cria o Fundo de Financiamento e Investimento para o Desenvolvimento Habitacional e Urbano e dá outras providências.

Federais

BRASIL. Lei ํo 11.977, de 27 de julho, de 2009. Dispõe sobre o Programa Minha Casa, Minha Vida - PMCMV e a regularização fundiária de assentamentos localizados em áreas urbanas; altera o Decreto-Lei no 3.365, de 21 de junho de 1941, as Leis nos 4.380, de 21 de agosto de 1964, 6.015, de 31 de dezembro de 
1973, 8.036, de 11 de maio de 1990, e 10.257, de 10 de julho de 2001, e a Medida Provisória no 2.197-43, de 24 de agosto de 2001; e dá outras providências.

BRASIL. Lei Federal 11.124, de 16 de junho de 2005. Dispõe sobre o Sistema Nacional de Habitação de Interesse Social - SNHIS, cria o Fundo Nacional de Habitação de Interesse Social - FNHIS e institui o Conselho Gestor do FNHIS. Brasília, 2005.

BRASIL. Lei Federal 11.888/2008, de 24 de dezembro de 2008. Assegura às famílias de baixa renda assistência técnica pública e gratuita para o projeto e a construção de habitação de interesse social e altera a Lei no 11.124, de 16 de junho de 2005. Brasília, 2008.

BRASIL. Constituição da República Federativa do Brasil de 1988. Brasília, 1988. Disponível em: <http://www.planalto.gov.br/ccivil_03/Constituicao/Constituicao.htm.> Acesso em 03 de abril de 2020. 
Sítios eletrônicos consultados

http://ambientearquitetura.com/

http://www.comunidadegta.org/

http://integraurbano.com.br/

http://www.peabirutca.org.br/

http://www.usina-ctah.org.br/]

http://www.caixa.gov.br

http://www.autogestao.unmp.org.br

https://www.observatoriodasmetropoles.net.br/ 